\title{
A DESREGULAMENTAÇÃO DO SETOR SUCROALCOOLEIRO BRASILEIRO
}

MÁRCIA AZANHA FERRAZ DIAS DE MORAES

Engenheiro Mecânico

Orientador: Prof. Dr. GERALDO SANT'ANA DE CAMARGO BARROS

Tese apresentada à Escola Superior de Agricultura "Luiz de Queiroz", Universidade de São Paulo, para obtenção do título de Doutor em Ciências, Área de Concentração: Economia Aplicada.

PIRACICABA

Estado de São Paulo - Brasil

Outubro de 1999 


\title{
Dados Internacionais de Catalogação na Publicação (CIP) DIVISÃo DE BIBLIOTECA E DOCUMENTAÇĀO - Campus "Luiz de Queiroz"/USP
}

\author{
Moraes, Márcia Azanha Ferraz Dias de \\ A desregulamentação do setor sucroalcooleiro brasileiro / Márcia Azanha \\ Ferraz Dias de Moraes. - - Piracicaba, 1999.
}

$292 \mathrm{p}$.

Tese (doutorado) - Escola Superior de Agricultura Luiz de Queiroz, 1999.

Bibliografia.

1. Açúcar 2. Álcool 3. Aspecto político-sócio-econômico 4. Cana-de-açúcar 5. Desregulamentaçăo 6. Economia politica 7 . Indústria sucro-alcooleira 8. Intervenção estatal 9. Legislação 10. Mercado agricola 11. Organização industrial Regulamentação I. Título

CDD 338.476641

Termitida a copia total ou parcial deste documento, desde que citada a fonte 0 Autor: 


\section{OFEREÇO}

Ao meu marido Omir,

com todo o meu amor.

\section{DEDICO}

Aos meus filhos, Luís Eduardo e Rafael. Espero que eles possam entender que 0 esforço necessário para se atingir um objetivo é totalmente compensado pela sua realização. 


\section{AGRADECIMENTOS}

Ao professor Geraldo Sant'Ana de Camargo Barros sou especialmente grata pela orientação segura, e pelas inúmeras vezes em que me indicou com clareza os caminhos a seguir. Sua leitura criteriosa e valiosos comentários durante as várias etapas da pesquisa foram responsáveis pelo engrandecimento do trabalho.

Em seu nome agradeço ao Centro de Pesquisa em Economia Aplicada (CEPEA), pelo suporte financeiro que possibilitou a realização das entrevistas. Da mesma forma, a bolsa de estudo recebida pela CAPES durante o curso foi de fundamental importância para a realização desta tese.

Aos professores Pedro Valentim Marques, Heloísa Lee Burnquist, Mírian R. Piedade Bacchi , e Oriowaldo Queda, do Departamento de Economia e Sociologia Rural da ESALQ, pelas importantes críticas e sugestões apresentadas durante a elaboração do trabalho.

Aos professores do Departamento de Economia e Sociologia Rural da ESALQ, pelos ensinamentos recebidos.

Aos amigos do Departamento de Economia e Sociologia Rural da ESALQ e do CEPEA - Pedro, Cristiani, Lú, Márcia, Elenice, Maria Helena, Cida, Luciene - pela colaboração e amizade. À Maielli, que sempre sorridente me socorreu dos apuros com as datas e prazos, um agradecimento especial. Falando em prazos, sou grata à Helena e à Ligiana, que na fase final do trabalho prontamente me ajudaram a vencê-los.

Agradeço a colaboração das pessoas entrevistadas, que dispuseram de seu tempo nas agendas apertadas, em reuniões que algumas vezes duraram mais de três horas, sem as quais a realização desta tese não teria sido possível.

Isto me faz lembrar da Dra. Elizabeth Serodio, que ao término de nossa entrevista, às 22:30, depois de um dia exaustivo da atividades, ainda achou tempo para me levar aos principais pontos turísticos da cidade.

Ao Caio, além do precioso tempo dispendido, sou grata por ter me presenteado com o tema desta tese, há três anos atrás, quando vislumbrou os enormes desafios a serem enfrentados pelo setor. Em nome da Denise e da Nívea, agradeço também a 
colaboração da equipe da UNICA, que sempre se mostrou pronta para fornecer os dados e informações solicitadas.

Da mesma forma, sou grata ao Dr. Ênio e ao Geraldo Magela pelas discussões e informações prestadas pela ORPLANA. Não poderia esquecer da colaboração da FEPLANA, agradecendo ao Dr. Antônio Celso Cavalcanti e à Sandra pelo envio dos dados solicitadas.

Aos meus amigos e familiares, cuja convivência com alguém que está escrevendo uma tese deve ser tão difícil quanto escrevê-la, sou grata e prometo que tão logo não começarei outra ...

Para o Omir, um agradecimento especial pelas tantas vezes que pacientemente me escutou falar sobre cana, açúcar e álcool, e que abriu mão das infindáveis horas que passei sentada em frente ao computador.

E a todos que, de forma direta ou indireta, contribuíram para o realização deste trabalho. 


\section{SUMÁRIO}

Página

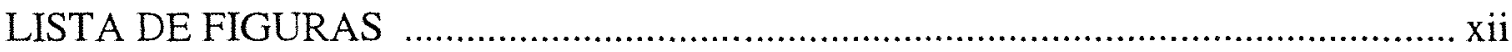

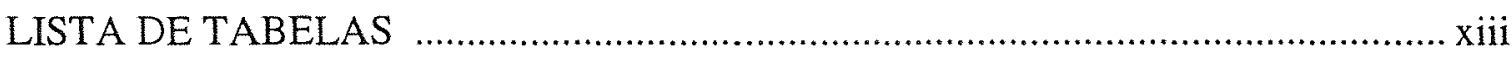

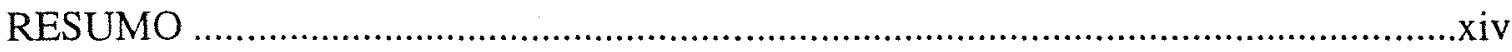

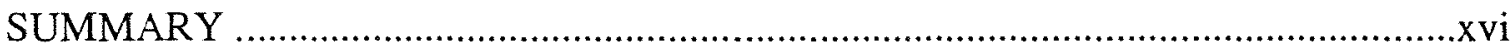

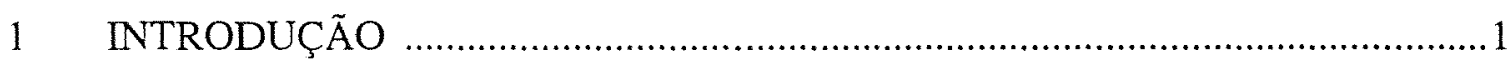

2 CARACTERIZAÇÃO DO SETOR SUCROALCOOLEIRO …………................6

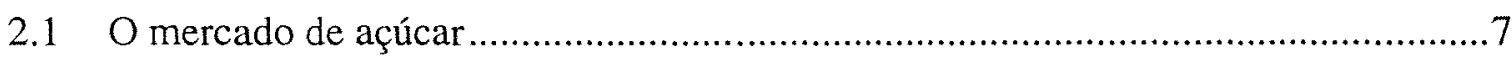

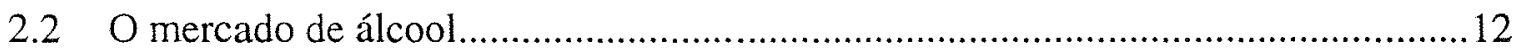

3 A INTERVENÇÃO ESTATAL E A EVOLUÇÃO DO SETOR ….....................16

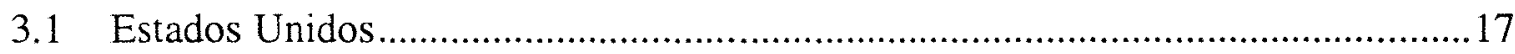

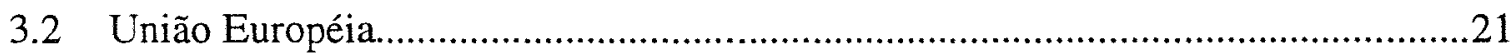

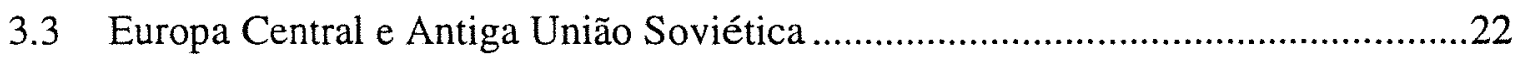

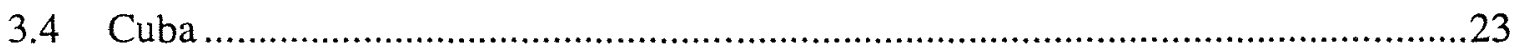

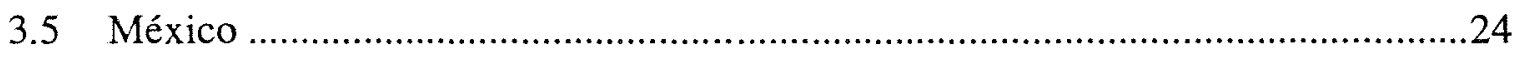

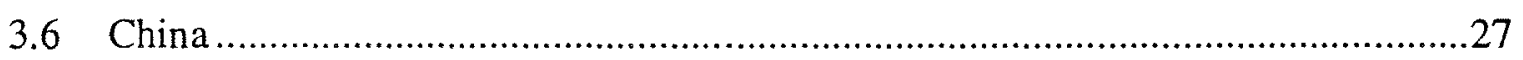

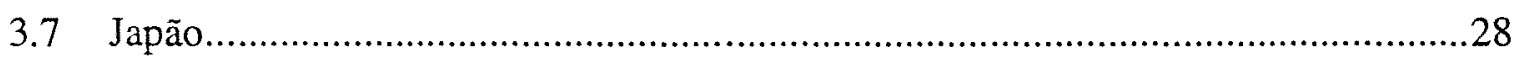

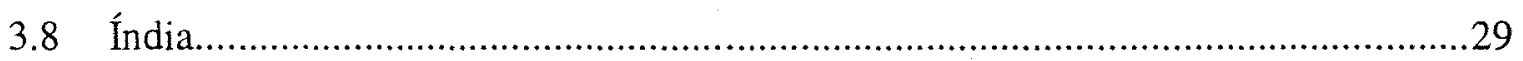

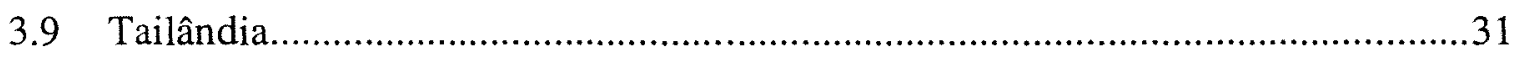

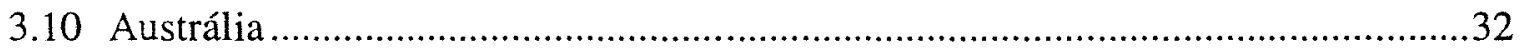

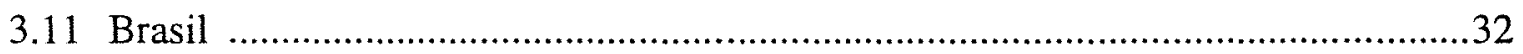


3.11.1 A década de 30: o início da intervenção estatal e a criação

do Instituto do Açúcar e do Álcool (IAA)

3.11.2 A década de 40: a criação do Estatuto da Lavoura

Canavieira, a II Guerra Mundial e a mudança da distribuição espacial da produção açucareira no País

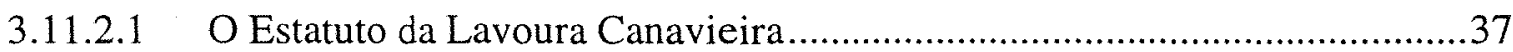

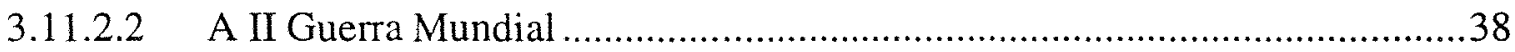

3.11.2.3 O Decreto-Lei № 9827 e a mudança da distribuição espacial da produção açucareira

3.11.3 A década de 50: a consolidação da produção do Centro-

Sul .43

3.11.3.1 Políticas de preços

3.11.4 A década de 60: o incentivo às exportações e a grave crise de superprodução da safra 1965/66

3.11.4.1 A lei $\mathrm{N}^{\mathrm{o}} 4870$ (dezembro de 65) e o pagamento da cana pelo Teor de Sacarose

3.11.4.2 Decreto Lei $N^{0} 1974$ (agosto de 1966): a divisão do País em duas regiões produtoras

3.11.5 A década de 70: o fomento às exportações, os programas de melhoria de produtividade e de racionalização da produção, os choques do petróleo e o desenvolvimento do Proálcool .52

3.11.5.1 O fomento às exportações, os programas de melhoria de produtividade e de racionalização da produção

3.11.5.2 $\mathrm{O} 1^{\mathrm{o}}$ choque do petróleo e o desenvolvimento do Proálcool .57

3.11.5.3 O $2^{\mathrm{o}}$ choque do petróleo e a retomada do Proálcool .71

3.11.6 A década de 80: a fase final de instalação do Proálcool, o esgotamento dos recursos governamentais, o descompasso entre a oferta e a demanda de álcool 
4.1 A Mudança Institucional: o processo de liberação, a

legislação pertinente e os diversos adiamentos 88

4.1.1 A Portaria do Ministério da Fazenda № 64 (março de 1996) .88

4.1.2 O $1^{\circ}$ adiamento da liberação: a Portaria do Ministério da Fazenda № 294 (dezembro de 1996)

4.1.3 O $2^{\mathrm{O}}$ adiamento da liberação: a Portaria do Ministério da Fazenda № 102 (abril de 1998)

4.1.4 O $3^{\circ}$ adiamento da liberação: a Portaria do Ministério da Fazenda № 275 (outubro de 1998).

4.1.5 A liberação dos preços: fevereiro de 1999. 92

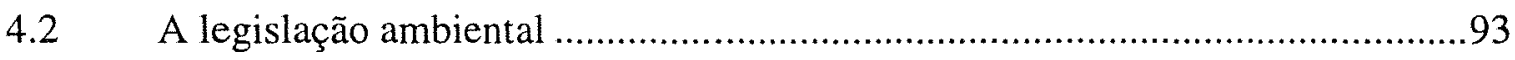

4.3 As mudanças no ambiente organizacional público .................................95

4.3.1 A extinção do Instituto do Açúcar e do Álcool (IAA)

4.3.2 Acriação do Conselho Interministerial do Açúcar e do Álcool (CIMA)

4.3.3 A criação da Agência Nacional do Petróleo (ANP) e a abertura do mercado de combustíveis

4.3.4 A criação da Associação dos Municípios Canavieiros do Estado de São Paulo (AMCESP)

4.3.5 A criação da Câmara Paulista do Setor Sucroalcooleiro ............................... 103

4.4 As mudanças no ambiente organizacional privado ................................... 103

4.4.1 A criação da UNICA .............................................................. 103

4.4.2 A fundação da CEPAAL ................................................................. 104

4.4.3 A criação da Brasil Álcool S/A .............................................................. 105

4.4.4 A fundação da Bolsa Brasileira de Álcool (BBA) ...................................... 108

4.5 As alterações decorrentes da desregulamentação nos suportes ao álcool combustível, à cana-de-açúcar e ao frete das regiões distantes 
Página

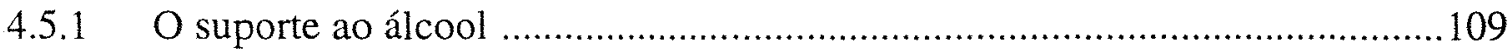

4.5.2 O suporte à cana-de-açúcar das regiões menos competitivas..........................112

4.5.3 O suporte ao frete das regiões mais distantes dos centros de consumo

4.6 As alterações sobre o controle da produção e comercialização: as cotas de produção e os Planos de safra, as exportações, e a cobrança diferenciada do IPI do açúcar

4.6.1 As cotas de produção e os Planos de Safra ....................................................114

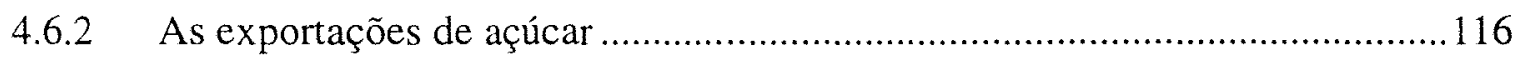

4.6.3 A cobrança diferenciada do Imposto sobre Produto Industrializado (IPI) sobre o açúcar de cana .

4.7 As mudanças na comercialização da cana-de-açúcar decorrentes da desregulamentação do setor

4.7.1 O CONSECANA 120

4.8 As mudanças na comercialização do álcool combustível decorrentes da desregulamentação do setor

4.8.1 A mesa de comercialização do governo

4.8.2 Os contratos firmados entre produtores e distribuidoras e o adiamento da liberação dos preços

4.9 As ações do CIMA durante o processo de desregulamentação

4.9.1 As compras de estoques de álcool

4.9.2 A nova sistemática de aquisição de álcool pelo governo: os leilões

4.9.3 Outras medidas tomadas pelo CIMA: incentivos à demanda.

4.10 As manifestações dos agentes em defesa do setor Sucroalcooleiro.

4.11 O Pacto pelo Emprego no Agronegócio Sucroalcooleiro 
5.1 Regulamentação de mercados

5.1.1 As falhas de mercado e suas correções

5.1.1.1 Regulamentação social: bens públicos, externalidades e problemas de informação

5.1.1.2 Regulamentação econômica: poder de monopólio decorrente do monopólio natural

5.1.1.3 Política antitruste: poder de monopólio devido às estruturas concentradas.

5.1.1.4 Os acordos entre as empresas, as fusões e os cartéis.

5.1.1.5 Política industrial: falhas intertemporais de mercado 151

5.1.2 As falhas de governo 152

5.1.3 As associações de interesse privado 154

5.2 A Nova Economia das Instituições ..................................................... 155

5.2.1 A Economia dos Custos de Transação - Williamsom (1985) .........................156

5.2.2 As Instituições - Douglas North ...................................................... 163

5.3 Determinantes Políticos dos Processos Decisórios .................................... 169

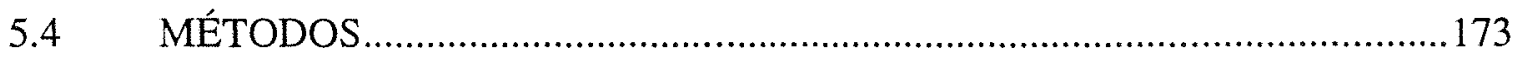

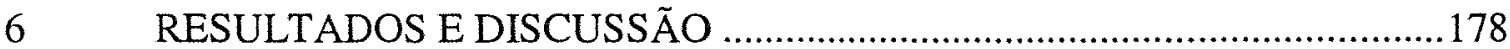

6.1 As características dos mercados de cana-de-açúcar, de açúcar e do álcool e do ambiente institucional: as falhas de mercado e as formas requeridas da ação estatal, e as estruturas de governança mais eficientes.

6.1.1 O mercado de cana-de-açúcar ........................................................179

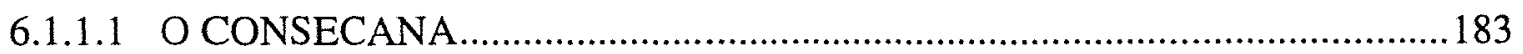

6.1.1.2 A diferença competitiva entre fornecedores de cana e industriais

6.1.2 O mercado de açúcar. 196 
Página

6.1.3 O mercado de álcool combustível .............................................................200

6.1.3.1 A falta de competitividade do álcool hidratado em relação a gasolina

6.1.3.2 As externalidades positivas da produção e uso do álcool combustível 204

6.1.3.3 O desequilíbrio competitivo entre produtores de álcool e distribuidoras de combustível.

6.1.3.4 A criação da Brasil Álcool e da Bolsa Brasileira de Álcool 224

6.1.3.5 O problema de assimetria de informação 227

6.1.4 As diferenças regionais 229

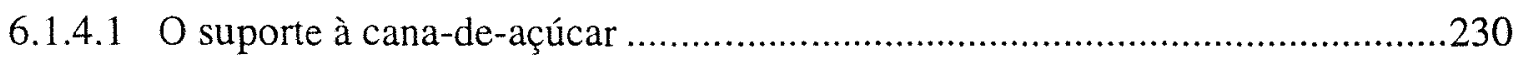

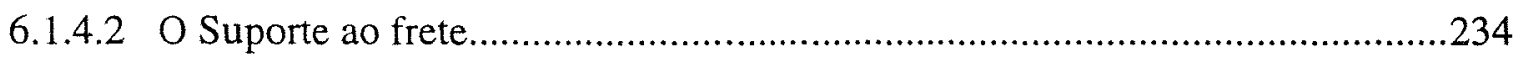

6.2 Determinantes políticos dos processos decisórios: os atores e seus recursos de poder e a redefinição de seus papéis no novo ambiente institucional

6.2.1 O processo de desregulamentação e os atores envolvidos 238

6.2.2 O novo ambiente desregulamentado: os novos atores e seus recursos de poder .244

7 CONCLUSÕES .255

ANEXOS .267

REFERÊNCIAS BIBLIOGRÁFICAS 279 APÊNDICE 


\section{LISTA DE FIGURAS}

Página

1 Evolução do número de usinas: Estados de São Paulo e Pernambuco

2 A evolução do setor açucareiro: 1935-1982 .54

3 Evolução dos preços mundiais de açúcar: 1970-1982 ..................................................56

4 Evolução dos preços do petróleo no mercado mundial .................................................58

5 Evolução da produção brasileira de álcool anidro, hidratado e total

Safras 1930/31-1981/82 (em milhões de litros) .68

6 Evolução das vendas de carros a álcool e a gasolina 82

7 Instituições e desempenho econômico 166

8 Variáveis relevantes na análise da transação 168 


\section{LISTA DE TABELAS}

Página

Tabela 1. Número de unidades produtoras e área de cana-de-açúcar cultivada por região na safra $1997 / 98$

Tabela 2. Açúcar Centrifugado: Produção, Oferta e Distribuição (Países

Selecionados) 1998/99 (em $10^{3}$ toneladas métricas) .8

Tabela 3. Evolução da participação nas exportações mundiais de açúcar

Tabela 4. Evolução da produção de açúcar no Brasil 1988/89 a 1998/99

(em sacas de $50 \mathrm{~kg}$ )

Tabela 5. Evolução das exportações brasileiras de açúcar por regiões

1988/89 a 1998/99 - (em toneladas)

Tabela 6. Evolução da produção brasileira de álcool - 1988/89 a 1998/99 (em metros cúbicos)

Tabela 7. Evolução da produção de cana-de-açúcar 1975/76-1997/98

(em toneladas)

Tabela 8. Formas de comercialização, volumes mensais e preços de álcool hidratado - Região Centro - Sul (1998)

Tabela 9. Número de fornecedores e participação na cana entregue safra $98 / 99$

Tabela 10. Distribuição dos produtores de cana por estratos - safra 1998/99 Estado de São Paulo

Tabela 11. Balanço das emissões líquidas de $\mathrm{CO}_{2}$ (equiv.) devido a produção de cana-de-açúcar e utilização de etanol - 1996. .208

Tabela 12. Evolução da participação percentual das distribuidoras no mercado de álcool hidratado 


\title{
A DESREGULAMENTAÇÃO DO SETOR SUCROALCOOLEIRO BRASILEIRO
}

\author{
Autora: MÁRCIA AZANHA FERRAZ DIAS DE MORAES \\ Orientador: Prof. Dr. GERALDO SANT'ANA DE CAMARGO BARROS
}

\section{RESUMO}

O principal objetivo deste trabalho foi estudar até que ponto é possível o afastamento do Estado do setor sucroalcooleiro brasileiro, e se este afastamento não for total, quais as novas formas requeridas da ação estatal. A partir das características dos mercados de cana-de-açúcar, de açúcar e do álcool procurou-se verificar a existência de falhas de mercado que indicassem a necessidade de regulamentação, utilizando para tal análise a Teoria Microeconômica, em sua vertente da Organização Industrial.

Considerando-se as características encontradas e o ambiente institucional buscou-se também identificar as estruturas de governança mais eficientes para se transacionar os produtos. Para tanto, apoiou-se na Economia dos Custos de Transação e na Nova Economia das Instituições.

Além disso, procurou-se determinar os principais atores e arenas decisórias envolvidos no processo de desregulamentação, e comparar a estrutura decisória atual com a da criação do Proálcool, sendo utilizados alguns conceitos de Economia Política.

O estudo mostrou que o afastamento do Estado deste setor não pode ser total. Embora as novas formas de atuação sejam distintas da anteriormente exercidas, já que devem estar alinhadas com a Constituição Federal de 1988 e com o regime democrático 
vigente, os Governos Federal, Estaduais e Municipais ainda têm importantes papéis a desempenhar.

As principais ações do Governo Federal referem-se à definição da matriz energética brasileira; à divulgação das necessidades de álcool combustível do país; ao direcionamento da produção entre álcool e açúcar de forma a atender as demandas dos produtos; a definição de um mecanismo tributário que permita a convivência dos dois combustíveis em livre mercado; à utilização de mecanismos tributários para adequar o uso do combustível alternativo; e à promoção da abertura do mercado externo para os produtos da cadeia.

Os Governos Estaduais podem atuar como coordenadores das Câmaras Setoriais, e, da mesma forma que o Governo Federal, monitorar a auto-gestão da cadeia sucroalcooleira (o afastamento do Estado deve ser substituído por mecanismos de autogestão e coordenação setorial) e dos agentes envolvidos no mercado de combustíveis. Devem usar os mecanismos tributários que permitam atender as demandas estimadas pelos combustíveis, considerando as questões de emprego e renda envolvidas em cada Estado. Os prefeitos dos municípios canavieiros podem promover incentivos à utilização do álcool combustível como forma de preservar a atividade em suas cidades.

Quanto aos atores e às arenas decisórias que influenciaram o processo de desregulamentação, destacaram-se as associações de produtores da região Centro-Sul, os sindicatos de produtores de açúcar e álcool da região Norte-Nordeste, as associações de fornecedores de cana, e os parlamentares das diversas regiões produtoras, cujos interesses diversos pressionavam os tomadores de decisão, sendo o CIMA a principal arena decisória.

No novo ambiente institucional, os principais atores determinantes das políticas públicas para o setor são: os parlamentares do Congresso Nacional, os Sindicatos de Trabalhadores, e os Governos Estaduais e municipais. O Governo Federal, que na fase de elaboração do Proálcool teve o papel principal, atualmente tem seu poder bastante reduzido, sendo suas ações canalizadas através do CIMA e da ANP, que, ao lado do Congresso Nacional, são as principais arenas decisórias. 


\title{
DEREGULATION OF THE BRAZILIAN SUGAR ALCOHOL SECTOR
}

\author{
Author: MÁRCIA AZANHA FERRAZ DIAS DE MORAES \\ Adviser: Prof. Dr. GERALDO SANT'ANA DE CAMARGO BARROS
}

\section{SUMMARY}

This study was conducted with the objective of determining to what extent the noninterference between the State and the sugar alcohol sector is possible and, if this is not total, which new state actions are required.

Based on the characteristics of the sugarcane, sugar and alcohol markets we studied possible flaws in the market which would indicate the need for regulation; for this analysis we used the Microeconomy Theory in its Industrial Organization stream.

We also tried to identify the most efficient governance structures for the transactions of the products; for that purpose we used the Transaction Costs Economics and the New Institutional Economics.

Besides that we tried to determine the most important actors and decision arenas involved in the process of deregulation, and compare the recent decision structures to that prevailing in the Proalcool, using concepts of Political Economy.

The study showed that the noninterference of the State can not be total. Although the new forms of involvement differ from the previous, the Federal, State and Municipal Governments still have important roles to perform. The new forms of involvement must be in accordance to the 1988 Federal Constitution and to the current democratic system. 
The most important actions of the Federal Government refer to the definition of the Brazilian energy matrix, informing the needs of alcohol fuel in the country, guiding the production between alcohol and sugar in order to meet the demands for the products, a definition of a taxation mechanism that allows the two fuels to share the market, the use of taxation to adjust the use of alternative fuel, and the promotion of the opening of the international market for the products of the agri-chain.

The State Governments should act as coordinators of Sector Chambers and, similarly to the Federal Government, should monitor the self-management of sugaralcohol chain (the state noninterference should be substituted by self-management mechanism and sector coordination) and should monitor the actions of the agents involved in the fuel markets. Also should use taxation that allows to meet the estimated demands for fuels, considering the matters of employment and income involved in each state.

The mayors in sugar cane cities should incentive the use of alcohol fuel as way of maintaining the activity in their cities.

The deregulation process was conducted by actors such as producers associations of the Center-South region, the unions of sugar and alcohol producers of the north-northeast region, the associations of cane sugar producers and the politicians from several sugarcane production regions, whose conflicting interests influenced the decision makers. CIMA was the main decision arena.

In the new institutional environment, the mains actors determining public policies for the sector are: the congressmen, the workers union, and the State and municipal governments. Once the main actor in the elaboration of Proalcool, lately the Federal Government has its power reduced, acting through CIMA and ANP, which like National Congress, are important decision arenas. 


\section{INTRODUÇÃo}

A questão central deste estudo, dada a diretriz oficial de desregulamentação do setor sucroalcooleiro no Brasil, é refletir sobre a a intensidade com que o Estado pode se afastar do mesmo, e, caso este afastamento não seja total, quais as novas formas requeridas da ação estatal no novo ambiente desregulamentado.

A partir da segunda metade da década de 80 iniciou-se na economia brasileira um processo generalizado de desregulamentação, intensificado a partir dos anos 90 , abrangendo várias cadeias agroindustrias (entre elas, café, trigo, leite e açúcar), as quais sofreram grandes alterações institucionais, já que extinguiu-se grande quantidade de regras, muitas das quais vigoravam há mais de 50 anos.

A cadeia agroindustrial sucroalcooleira certamente era uma das mais controladas administrativamente pelo Estado brasileiro. Desde a década de 30 o governo estabelecia a produção (incluindo fixação de cotas de produção de açúcar e de álcool para cada unidade industrial), se encarregava da comercialização dos produtos (ditando os preços da tonelada da cana, do açúcar e dos combustíveis, e determinando os respectivos compradores e vendedores para o álcool combustível), além de ser o responsável por toda a exportação do açúcar e de álcool.

Desta forma, 'a desregulamentação deste setor afeta as relações dos agentes de toda a cadeia produtiva: os produtores de cana-de-açúcar, as usinas e destilarias e as distribuidoras de combustível, como também os consumidores de álcool e açúcar, na medida que novos patamares de preços provavelmente irão vigorar no novo ambiente desregulamentado. 
Como pano de fundo da desregulamentação, temos a mudança de um regime político com fortes traços burocráticos e autoritário, para um sistema com características mais democráticas. Esta alteração, do autoritarismo, que favorecia as decisões centralizadas, para a democracia, que fortalece o papel do Congresso (já que se exigem regras mais claras e o estabelecimento de parâmetros legais para a atuação do governo), evidenciou uma mudança importante dos papéis desempenhados por cada um dos atores envolvidos nos determinantes das políticas públicas, de forma a lidar com o novo ambiente institucional estabelecido.

Neste sentido, a promulgação da Constituição Federal de 1988 reforçou o poder do Congresso (que volta a ser responsável pela aprovação do Orçamento da União) e diminuiu o papel do Estado como interventor na economia brasileira (cuja ação de planejamento passou ter caráter apenas indicativo), alterando completamente as relações entre Estado e setor sucroalcooleiro anteriormente estabelecidas.

Portanto, com as mudanças institucionais, muitas das funções previamente exercidas pelo governo passaram a ser de responsabilidade dos diversos segmentos envolvidos nas cadeias produtivas, evidenciando as profundas mudanças por eles enfrentadas e a necessidade de uma reorganização do sistema como um todo.

Conforme FARINA (1996, p.2), é importante identificar "as tendências de reorganização das cadeias produtivas, as novas regras de concorrência que irão, provavelmente, se impor, e o papel a ser cumprido pelas diferentes organizações econômicas - empresas, Estado e associações de interesse privado - na coordenação dos negócios agroindustriais".

O início da desregulamentação pela qual passa o setor se dá, no nosso entender, no Governo Collor, quando foi extinto o Instituto do Açúcar e do Álcool, e atingiu seu apogeu com a Portaria do Ministério da Fazenda № 275 , de 16 de outubro de 1998, a 
qual liberou, a partir de $1^{\circ}$ de fevereiro de 1999 , os preços da tonelada de cana-de-açúcar, do açúcar standard e do álcool de todos os tipos!

Neste trabalho pretende-se inicialmente analisar o processo de desregulamentação do setor sucroalcooleiro brasileiro e seus efeitos sobre a cadeia produtiva, sendo focalizados dois elos principais deste sistema, que até então tinham a comercialização de seus produtos controlados pelo governo: aqueles formados entre fornecedores de cana-de-açúcar e produtores de açúcar e de álcool (usinas de açúcar e álcool e destilarias autônomas ${ }^{2}$ ), e entre usinas e destilarias e distribuidoras de combustíveis.

Também é objeto de estudo a verificação de algumas características dos mercados de cana-de-açúcar, de açúcar e do álcool que indiquem a existência de falhas de mercado que permitam identificar qual o novo papel a ser desempenhado pelos agentes econômicos neste novo ambiente desregulamentado, incluindo aí a nova forma requerida da ação estatal.

Além disso, a partir das características de mercado encontradas, pretende-se determinar também as formas mais eficientes de se transacionar os insumos e produtos, considerando-se o novo ambiente institucional que se apresenta.

No decorrer do trabalho foi ficando bastante claro que as políticas para o setor desenhadas pelo governo não consideravam somente questões econômicas, mas eram bastante influenciadas por outros fatores - sociais e políticos - sendo que em muitas ocasiões estes pareciam prevalecer, explicando algumas medidas adotadas pelo Estado. Portanto, os três fatores - políticos, sociais e econômicos - foram considerados para enriquecer a análise sobre as escolhas das políticas governamentais relativas à desregulamentação e desenvolvimento do setor.

\footnotetext{
1 Existem diversos tipos de álcool, dentre eles: o álcool hidratado, que é usado diretamente como combustível e pelas indústrias de bebida, química e farmacêutica; o álcool anidro é misturado à gasolina como oxigenante (atualmente na proporção de 0,24 para 1 litro) e também em indústrias não alimentícias; e o álcool neutro, usado nas indústrias alimentícia, química e farmacêutica.

${ }^{2}$ As usinas podem produzir tanto álcool como açúcar, já as destilarias autônomas fabricam somente álcool, o que as impede de escolher entre o açúcar e o álcool conforme seus preços relativos.
} 
Desta forma, pretende-se também identificar os principais agentes envolvidos no processo de desregulamentação. A partir do novo ambiente institucional desregulamentado, almeja-se relacionar os atores e recursos de poder e as arenas decisórias que passam a ser determinantes nas escolhas de políticas referentes ao setor.

Três instrumentais teóricos deram suporte à analise do processo de desregulamentação e seus efeitos sobre a cadeia produtiva: a vertente de Organização Industrial da Microeconomia tradicional; a Nova Economia das Instituições, e algumas idéias chaves sobre os determinantes políticos das políticas governamentais. Procurouse, portanto, incorporar informações históricas, políticas e institucionais para melhor compreensão do processo de desregulamentação.

A hipótese da tese é que não é viável o completo afastamento do Estado do setor sucroalcooleiro, conforme aconteceu em outras cadeias agroindustriais, dadas algumas características dos mercados produtor e consumidor existentes.

A estrutura do trabalho apresenta-se da seguinte forma: no capítulo dois é feita uma caracterização do setor sucroalcooleiro mundial e do brasileiro, a fim de mostrar sua importância relativa dentro da economia nacional.

No capítulo três discorre-se brevemente sobre as formas de intervenção existentes no setor açucareiro (e alcooleiro) dos principais países produtores e consumidores, e sobre alguns aspectos da desregulamentação pela qual alguns deles passaram. Também é feita uma revisão sobre a intervenção estatal na agroindústria sucroalcooleira brasileira e de seus efeitos sobre a evolução do setor, para que se tenha uma melhor compreensão da magnitude da interferência do Estado e dos seus efeitos sobre esta cadeia produtiva.

Com isto pretende-se enfatizar a intensidade dos efeitos da desregulamentação sobre um setor que desde os anos 30 viveu sob a égide do Estado, e que agora sente a necessidade de aprender a lidar com as regras impostas pela economia de mercado.

O quarto capítulo expõe o processo de desregulamentação que o setor atravessa, incluindo as principais decisões governamentais. No capítulo cinco apresenta-se o ferramental teórico e os métodos utilizados, e o capítulo seis traz os resultados e sua 
discussão. Finalmente, as conclusões estão no capítulo sete, seguido da Bibliografia consultada. 


\section{CARACTERIZAÇÃO DO SETOR SUCROALCOOLEIRO}

O Sistema Agroindustrial Sucroalcooleiro brasileiro tem grande importância tanto no mercado doméstico como no de exportação, diferenciando-se dos demais países por produzir, em escala industrial, tanto açúcar como álcool. No setor existem aproximadamente 335 fábricas, sendo que 55\% são mistas (produzem álcool e açúcar), 5\% são produtoras somente de açúcar, e o restante (aproximadamente 40\%) são destilarias autônomas (que só produzem álcool).

Conforme Serodio (1999) na safra de 1998/99 foram cultivados 4 milhões de hectares com cana-de-açúcar; que produziram 310 milhões de toneladas de cana-deaçúcar; 17 milhões de toneladas de açúcar e 13,5 bilhões de litros de álcool.

Quanto ao consumo interno, neste período foram consumidos, conforme a autora, 9 milhões de toneladas de açúcar e 14,2 bilhões de litros de álcool, sendo cerca de 13 bilhões de litros utilizados como combustível.

O setor sucroalcooleiro brasileiro pode ser dividido em duas regiões bastante distintas: Norte-Nordeste e Centro-Sul ${ }^{3}$, cujas vocações, estratégias e níveis de produtividade são diferentes.

O principal produto da região Norte-Nordeste é o açúcar, e do Centro-Sul era principalmente o álcool combustível, embora desde a safra 1991/92 sua produção de açúcar venha crescendo acentuadamente (já tendo ultrapassado em muito a produção da Região Norte-Nordeste, inclusive no que se refere às exportações).

\footnotetext{
${ }^{3}$ Os seguintes Estados fazem parte da Região Norte-Nordeste: Alagoas, Bahia, Ceará, Maranhão, Pará, Paraíba, Pernambuco, Piauí, Rio Grande do Norte, Sergipe e Tocantins. Da região Centro-Sul: São Paulo, Paraná, Minas Gerais, Mato Grosso, Mato Grosso do Sul, Goiás, Rio de Janeiro, Espírito Santo e Rio Grande do Sul e Santa Catarina.
} 
A distribuição espacial da indústria sucroalcooleira no Brasil na safra 1997/98 está na tabela 1 .

Tabela1. Número de unidades produtoras e área de cana-de-açúcar cultivada por região na safra 1997/98.

\begin{tabular}{lcrrr}
\hline Região & $N^{0}$ usinas & \% Brasil & Área Cultivada (ha) & \% Brasil \\
\hline C/S & 235 & 71,00 & $2.343 .328,35$ & 79,24 \\
\hline SP & 133 & 40,18 & $1.673 .301,41$ & 56,58 \\
PR & 28 & 8,46 & $167.556,48$ & 5,67 \\
MG & 24 & 7,25 & $128.984,37$ & 4,36 \\
MT & 10 & 3,02 & $122.911,55$ & 4,16 \\
GO & 14 & 4,23 & $110.177,72$ & 3,73 \\
MS & 9 & 2,72 & $56.444,05$ & 1,91 \\
RJ & 10 & 3,02 & $43.564,77$ & 1,47 \\
ES & 6 & 1,81 & $39.708,00$ & 1,34 \\
RS & 1 & 0,30 & 680 & 0,02 \\
\hline N/NE & 96 & 29,0 & $267.135,28$ & 9,03 \\
\hline AL & 30 & 9,1 & $267.135,28$ & 9,03 \\
PE & 34 & 10,3 & $200.146,70$ & 6,77 \\
PB & 9 & 2,7 & $52.334,42$ & 1,77 \\
BA & 6 & 1,8 & $32.648,17$ & 1,10 \\
RN & 4 & 1,2 & $23.000,00$ & 0,78 \\
SE & 1 & 0,3 & $15.500,00$ & 0,52 \\
MA & 4 & 1,2 & $9.108,46$ & 0,31 \\
CE & 4 & 1,2 & $2.800,00$ & 0,09 \\
PI & 1 & 0,3 & $7.500,00$ & 0,25 \\
PA & 2 & 0,6 & $3.738,41$ & 0,13 \\
TO & 1 & 0,3 & 0 & 0,00 \\
\hline Brasil & 331 & 100,0 & $2.957 .239,79$ & 100,00 \\
\hline
\end{tabular}

Fonte: Anuário Jornal da Cana.

\subsection{O mercado de açúcar}

Em relação ao mercado mundial de açúcar, alguns dados sobre o Brasil merecem destaque: está entre os três maiores produtores, sendo o maior fabricante de açúcar de cana; é o maior exportador (responde por $20,7 \%$ do comércio mundial e 
exporta cerca de $44 \%$ do que produz); é responsável por $89,7 \%$ da produção do Mercosul, por $96,7 \%$ das exportações, e $84,4 \%$ do consumo do bloco (Serodio, 1999).

Tabela 2. Açúcar Centrifugado: Produção, Oferta e Distribuição (Países Selecionados) 1998/99 (em $10^{3}$ toneladas métricas).

\begin{tabular}{lrrrrrrr}
\hline $\begin{array}{l}\text { Países/ } \\
\text { Blocos }\end{array}$ & $\begin{array}{c}\text { Estoques } \\
\text { Iniciais }\end{array}$ & Produção & Importações & Oferta & Exportaçóes & $\begin{array}{r}\text { Consumo } \\
\text { Doméstico }\end{array}$ & $\begin{array}{r}\text { Estoques } \\
\text { Finais }\end{array}$ \\
\hline U. & 3.000 & 18.000 & 1.790 & 22.790 & 5.440 & 14.500 & 2.850 \\
Européia & & & & & & & \\
Índia & 5.700 & 16.826 & 400 & 22.926 & 60 & 17.200 & 6.660 \\
Brasil & 560 & 16.600 & 0 & 17.160 & 7.200 & 9.100 & 860 \\
China & 2.597 & 8.727 & 885 & 12.209 & 355 & 9.129 & 2.725 \\
EUA & 1.520 & 7.300 & 1.976 & 10.796 & 159 & 9.095 & 1.542 \\
Austrália & 237 & 5.417 & 2 & 5.656 & 4.420 & 995 & 241 \\
México & 634 & 5.100 & 30 & 5.764 & 1.000 & 4.130 & 634 \\
Tailândia & 633 & 4.220 & 0 & 4.853 & 2.600 & 1.700 & 553 \\
Paquistão & 623 & 3.648 & 0 & 4.271 & 700 & 3.150 & 421 \\
Cuba & 300 & 3.200 & 0 & 3.500 & 2.500 & 690 & 310 \\
Áfr. do Sul & 364 & 2.700 & 0 & 3.064 & 1.400 & 1.295 & 369 \\
Total dos & 16.168 & 91.738 & 5.083 & 112.989 & 25.834 & 70.984 & 16.171 \\
11 países & & & & & & & \\
\hline Total & 25.191 & 126.516 & 34.814 & 186.521 & 34.814 & 127.515 & 24.192 \\
Mundial & & & & & & &
\end{tabular}

Fonte: Elaborado a partir de Serodio (1999).

Analisando-se os dados da tabela 2, nota-se que os 4 maiores produtores respondem por aproximadamente $47,55 \%$ da produção; que o consumo mundial é de $68,5 \%$ da oferta, sendo que são mantidos em estoque $13,5 \%$ do total ofertado e comercializado somente $18,5 \%$. O consumo mundial também está bastante concentrado: os cinco maiores consumidores consomem aproximadamente $46 \%$ do total consumido.

Vê-se que na safra $98 / 99$ o Brasil foi responsável por $12 \%$ do total das exportações. A participação e o volume brasileiro exportado têm crescido bastante nos últimos anos, o que tem provocado certa inquietação no mercado internacional, dado o excedente mundial existente, sendo uma das causas identificadas pelas quedas 
acentuadas de preço do produto. A evolução da participação do Brasil nas exportações mundiais estão na tabela 3 .

Tabela 3. Evolução da participação nas exportações mundiais de açúcar.

\begin{tabular}{cccc}
\hline Países & $86 / 87$ & $95 / 96$ & $98 / 99$ \\
\hline Brasil & $8,0 \%$ & $19,4 \%$ & 20,7 \\
Tailândia & $8,0 \%$ & $16,6 \%$ & 7,47 \\
Austrália & $11,5 \%$ & $15,7 \%$ & 12,7 \\
Cuba & $29,0 \%$ & $13,6 \%$ & 7,18 \\
EUA & $12,5 \%$ & $8,9 \%$ & 0,46 \\
Outros & $31,0 \%$ & $25,8 \%$ & 51,52
\end{tabular}

Fonte: Elaborado a partir de Carvalho (1997) e Serodio (1999).

Observa-se pelos dados da tabela 3 que entre as safras 86/87 e 95/96 houve um aumento da participação brasileira no mercado global de aproximadamente $142 \%$.

Em relação à distribuição nacional da produção de açúcar, verifica-se que atualmente a mesma é bastante concentrada na região Centro-Sul. A evolução da produção de açúcar no Brasil das últimas 10 safras, das regiões Norte-Nordeste, CentroSul, e a total do Brasil estão na tabela 4.

Nota-se que entre as safras de 1988/89 e 1998/99 o crescimento da produção de açúcar no Brasil foi de aproximadamente $123 \%$. É interessante observar a acentuada expansão da produção de açúcar observada na Região Centro-Sul (enquanto na Região Norte-Nordeste houve um decréscimo de 1,24\%, na Região Centro-Sul o aumento verificado no período foi de quase $190 \%$ ), o que pode ser explicado pelo fato que partir da safra 1990/91 esta região direcionou grande parte do crescimento observado na moagem da cana-de-açúcar para a fabricação de açúcar, apresentando crescimento bem menos acentuados da produção de álcool. 
Tabela 4 - Evolução da produção de açúcar no Brasil - 1988/89 a 1998/99 (em sacas de $50 \mathrm{~kg}$ ).

\begin{tabular}{cccc}
\hline & \multicolumn{3}{c}{ Regiões } \\
\cline { 2 - 4 } Safras & Norte-Nordeste & Centro-Sul & Brasil \\
$88 / 89$ & 56.336 .873 & 105.064 .248 & 161.401 .121 \\
$89 / 90$ & 61.485 .996 & 82.794 .983 & 144.280 .979 \\
$90 / 91$ & 57.130 .330 & 90.176 .559 & 147.306 .889 \\
$91 / 92$ & 55.392 .638 & 116.693 .786 & 172.086 .424 \\
$92 / 93$ & 62.601 .365 & 122.623 .774 & 185.225 .139 \\
$93 / 94$ & 45.304 .123 & 140.173 .466 & 185.477 .589 \\
$94 / 95$ & 64.229 .544 & 170.301 .223 & 234.530 .767 \\
$95 / 96$ & 66.751 .480 & 186.306 .290 & 253.057 .770 \\
$96 / 97$ & 63.696 .840 & 209.567 .700 & 273.264 .540 \\
$97 / 98$ & 70.524 .320 & 227.687 .920 & 298.212 .240 \\
$98 / 99$ & 55.636 .600 & 303.596 .480 & 359.233 .080 \\
\hline Variação \% & $-1,24 \%$ & $188,96 \%$ & $122,57 \%$ \\
$(1988 / 89-1998 / 99)$ & & & \\
\hline
\end{tabular}

Fonte: Única.

O aumento da produção de açúcar na região Centro-Sul criou excedentes importantes, já que seu consumo aparente aumentou em proporção menor que a produção durante o período analisado. Conforme CARVALHO (1997), na região Centro Sul, entre as safras de 92/93 e 96/97 o aumento do consumo aparente foi de aproximadamente $24 \%$, enquanto o aumento da produção foi de $71 \%$.

Quanto às exportações brasileiras totais de açúcar, nota-se que as mesmas vêm apresentando tendência de crescimento entre as safras 1988/89 a 1998/99. A tabela 5 traz a evolução das exportações brasileiras das últimas dez safras.

Nota-se pelos dados da tabela que embora o volume total exportado tenha aumentado no período $315,46 \%$, as exportações da Região Norte-Nordeste, que na safra 1988/89 representavam $88 \%$ do total das exportações, reduziram-se de aproximadamente $40 \%$ nas dez últimas safras, invertendo totalmente sua condição de maior região exportadora, passando a representar aproximadamente $13 \%$ do total exportado.

Por sua vez, tem havido um aumento do volume exportado pela região CentroSul, que passou a responder por aproximadamente $83 \%$ das exportações brasileiras de açúcar. 
Tabela 5. Evolução das exportações brasileiras de açúcar por regiões 1988/89 a 1998/99 - (em toneladas).

\begin{tabular}{cccc}
\hline & \multicolumn{3}{c}{ Regiões } \\
\cline { 2 - 4 } Safras & Norte-Nordeste & Centro-Sul & Brasil \\
$88 / 89$ & 1.363 .921 & 182.111 & 1.546 .032 \\
$89 / 90$ & 1.250 .524 & 285.844 & 1.536 .368 \\
$90 / 91$ & 1.197 .013 & 208.269 & 1.405 .282 \\
$91 / 92$ & 1.302 .528 & 401.919 & 1.704 .447 \\
$92 / 93$ & 1.312 .807 & 831.837 & 2.144 .644 \\
$93 / 94$ & 862.535 & 1.692 .454 & 2.554 .989 \\
$94 / 95$ & 1.815 .924 & 2.315 .457 & 4.167 .381 \\
$95 / 96$ & 1.639 .355 & 2.877 .492 & 4.516 .847 \\
$96 / 97$ & 1.484 .044 & 3.319 .430 & 4.803 .474 \\
$97 / 98$ & 2.060 .711 & 4.062 .442 & 6.123 .153 \\
$98 / 99$ & 819.828 & 5.603 .272 & 6.423 .100 \\
\hline Variação \% & $-39,9 \%$ & $2.976,84 \%$ & $315,46 \%$ \\
\hline
\end{tabular}

Fonte: (Queiroz Neto, 1999).

Ao se analisar as causas prováveis do grande aumento de produção e das exportações brasileiras de açúcar durante este período, deve-se considerar os problemas da falta de crédito e de liquidez enfrentados pelos produtores durante esta década.

A falta de crédito (tanto na área agrícola, para plantio e tratos culturais, como para a manutenção dos estoques de álcool durante o ano devido a sazonalidade da sua produção, que é feita em seis meses e comercializada ao longo do ano), levou os produtores a se utilizarem do mercado externo como forma de financiar a produção e aumentar sua liquidez, através da antecipação dos recursos feita pelas ACC (adiantamentos de carta de crédito).

Desta forma, através das exportações de açúcar, os produtores conseguiam financiar sua produção, e amenizavam seus problemas de liquidez, já que deste modo conseguia-se recursos mais rápidos do que os proporcionados pela comercialização do álcool feita ao longo do ano. 


\section{$2.2 \mathrm{O}$ mercado de álcool}

Em novembro de 1975, através do Decreto 76.595, o presidente Ernesto Geisel criou o Pró-álcool, um programa de incentivo à produção do álcool visando alternativas para enfrentar a crise do petróleo - que ameaçava as economias mundiais importadoras do produto - e que alterou significativamente o perfil da produção de açúcar e álcool do país, além de estimular um aumento significativo da área plantada de cana-de-açúcar. A evolução da produção de álcool no Brasil pode ser vista na tabela 6 .

Tabela 6. Evolução da produção brasileira de álcool - 1975/76 a 1998/99 (em metros cúbicos).

\begin{tabular}{lccc}
\hline & \multicolumn{3}{c}{ Regiões } \\
\cline { 2 - 4 } Safras & Norte-Nordeste & Centro-Sul & Brasil \\
$75 / 76$ & 93.790 & 461.837 & 555.627 \\
$76 / 77$ & 110.511 & 552.087 & 662.598 \\
$77 / 78$ & 207.795 & 1.262 .609 & 1.470 .404 \\
$78 / 79$ & 411.252 & 2.079 .351 & 2.490 .603 \\
$79 / 80$ & 569.245 & 2.827 .210 & 3.396 .455 \\
$80 / 81$ & 650.472 & 3.055 .903 & 3.706 .375 \\
$81 / 82$ & 825.720 & 3.414 .403 & 4.240 .123 \\
$82 / 83$ & 1.188 .288 & 4.635 .051 & 5.823 .339 \\
$83 / 84$ & 1.129 .635 & 6.734 .573 & 7.864 .208 \\
$84 / 85$ & 1.603 .841 & 7.588 .488 & 9.129 .329 \\
$85 / 86$ & 2.031 .045 & 9.799 .459 & 11.830 .504 \\
$86 / 87$ & 2.205 .646 & 8.301 .066 & 10.506 .712 \\
$87 / 88$ & 1.790 .598 & 9.667 .798 & 11.458 .396 \\
$88 / 89$ & 1.680 .792 & 9.964 .090 & 11.644 .882 \\
$89 / 90$ & 2.019 .567 & 9.900 .908 & 11.920 .475 \\
$90 / 91$ & 1.807 .301 & 9.707 .850 & 11.515 .151 \\
$91 / 92$ & 1.748 .879 & 10.967 .301 & 12.716 .180 \\
$92 / 93$ & 1.630 .565 & 10.066 .470 & 11.697 .035 \\
$93 / 94$ & 912.914 & 10.372 .676 & 11.285 .590 \\
$94 / 95$ & 1.549 .613 & 11.147 .167 & 12.696 .780 \\
$95 / 96$ & 1.734 .219 & 10.849 .173 & 12.583 .392 \\
$96 / 97$ & 2.266 .093 & 12.113 .607 & 14.379 .700 \\
$97 / 98$ & 2.144 .936 & 13.262 .578 & 15.407 .514 \\
$98 / 99$ & 1.631 .216 & 12.280 .991 & 13.912 .107 \\
\hline Variação\% & $1.639,22 \%$ & $2.559,16 \%$ & $2.403,86 \%$ \\
\hline Fone: Orna & & & \\
\hline
\end{tabular}

Fonte: Única. 
Nota-se pelos dados da tabela 6 o aumento verificado da produção de álcool, principalmente na segunda fase do Proálcool (a partir do ano 1979). Por sua vez, ao analisar-se a evolução da produção de álcool durante as dez últimas safras, verifica-se pelos que na Região Norte-Nordeste ela reduziu-se aproximadamente $3 \%$, enquanto na região Centro-Sul houve um crescimento de $23 \%$.

A elevação da produção de álcool fez com que também se aumentasse muito a demanda de cana-de-açúcar do País, com consequiente aumento de sua produção e expansão para regiões não tradicionalmente produtoras. A evolução da produção de cana de açúcar pode ser vista na Tabela 7.

Tabela 7. Evolução da produção de cana-de-açúcar 1975/76$1997 / 98$ (em toneladas).

\begin{tabular}{lccc}
\hline Safras & Norte-Nordeste & Centro-Sul & Brasil \\
\hline $1975 / 76$ & 25.600 .659 & 42.721 .960 & 68.322 .619 \\
$1976 / 77$ & 34.530 .942 & 53.295 .722 & 87.826 .664 \\
$1977 / 78$ & 35.683 .051 & 68.950 .744 & 104.633 .795 \\
$1978 / 79$ & 36.169 .466 & 71.456 .911 & 107.626 .377 \\
$1979 / 80$ & 35.224 .179 & 77.424 .244 & 112.648 .423 \\
$1980 / 81$ & 40.248 .489 & 82.758 .192 & 123.006 .681 \\
$1981 / 82$ & 41.731 .267 & 91.155 .075 & 132.886 .342 \\
$1982 / 83$ & 50.210 .312 & 115.968 .280 & 166.178 .592 \\
$1983 / 84$ & 52.221 .376 & 144.521 .565 & 196.742 .941 \\
$1984 / 85$ & 57.072 .802 & 144.146 .135 & 201.218 .937 \\
$1985 / 86$ & 61.068 .406 & 162.567 .473 & 223.635 .879 \\
$1986 / 87$ & 71.259 .260 & 154.280 .668 & 225.539 .928 \\
$1987 / 88$ & 54.700 .317 & 167.734 .336 & 222.434 .653 \\
$1988 / 89$ & 53.617 .400 & 166.486 .980 & 220.104 .380 \\
$1989 / 90$ & 60.466 .023 & 162.436 .320 & 222.902 .343 \\
$1990 / 91$ & 52.234 .501 & 170.194 .659 & 222.429 .160 \\
$1991 / 92$ & 50.191 .326 & 179.030 .917 & 229.222 .243 \\
$1992 / 93$ & 47.164 .430 & 176.295 .436 & 223.459 .866 \\
$1993 / 94$ & 34.421 .824 & 184.088 .464 & 218.510 .288 \\
$1994 / 95$ & 44.629 .258 & 196.314 .744 & 240.944 .002 \\
$1995 / 96$ & 47.413 .177 & 203.944 .477 & 251.357 .654 \\
$1996 / 97$ & 56.205 .772 & 231.604 .080 & 287.809 .852 \\
$1997 / 98$ & 54.281 .977 & 249.691 .936 & 303.973 .913 \\
$1998 / 99$ & 45.141 .192 & 269.827 .990 & 314.969 .182 \\
\hline Variação \% no & $76,33 \%$ & $531,59 \%$ & $361 \%$ \\
período & & & \\
\hline
\end{tabular}

Fonte: elaborada a partir de dados da ÚNICA. 
Nota-se pelos dados da tabela 7 que entre 1975/76 e 1998/99 a produção brasileira de cana-de-açúcar cresceu aproximadamente $360 \%$, sendo que na região Centro-Sul o aumento verificado (aproximadamente 530\%) foi bem maior que na Região Norte-Nordeste $(76 \%)$.

Em relação à evolução da produção de cana-de-açúcar durante as dez últimas safras (1988/89 e 1998/99) verifica-se que ela cresceu aproximadamente 43\%, sendo que a Região Centro-Sul foi a responsável pelo crescimento observado no período (que na referida região foi de $62 \%$ ), já que na região Norte-Nordeste houve uma redução aproximada na produção de $16 \%$.

Em relação ao mercado mundial de álcool, o Brasil é o maior produtor de etanol do mundo, sendo que em 1998 foi responsável por aproximadamente $58 \%$ da produção total: dos 23,63 bilhões de litros produzidos mundialmente o Brasil participou com 13,8 bilhões, seguido pelos Estados Unidos (5,75 bilhões), da Europa (1,29 bilhão). A seguir vêm a Ásia (1,51 bilhão de litros), a África ( 0,98 bilhão de litros) e a Oceania ( 0,3 bilhão de litros), conforme Nastari (1999).

Em relação aos dois maiores produtores mundiais, Brasil e Estados Unidos, nota-se, conforme Serodio (1999), diferenças e semelhanças. A primeira diferença citada refere-se à matéria-prima: enquanto no Brasil o álcool é feito a partir da cana-de-açúcar, nos Estados Unidos é feito do milho; a outra é quanto à forma da intervenção estatal: no Brasil, o incentivo inicial ao álcool combustível foi feito pelo Governo Federal, de forma centralizada, e nos Estados Unidos o estímulo ao produto veio de diversos Estados, para prestigiar a atividade rural (existindo inclusive a coalizão dos governadores de 28 estados americanos pró-etanol).

Naquele país a colaboração da esfera federal é feita através da isenção fiscal parcial do imposto federal cobrado sobre a gasolina (Excise Tax), que sofre uma redução em função do teor de álcool anidro adicionado. Além disso, na origem a preocupação ambiental não estava no cerne do programa brasileiro, o que já ocorre nos Estados Unidos. 
Em relação às semelhanças atuais, Serodio (1999) cita a questão do emprego, da melhoria da qualidade do ar, contenção do efeito estufa, redução da dependência de suprimentos externos de energia e o aumento da renda rural. 


\section{A INTERVENÇÃO ESTATAL E A EVOLUÇÃO DO SETOR}

Neste capítulo faz-se uma breve revisão sobre as formas de intervenção existentes nos principais países produtores e consumidores. Além disso, analisa-se a intervenção estatal na agroindústria sucroalcooleira do Brasil, e seus efeitos sobre o desenvolvimento deste setor.

Tanto a produção como o comércio de açúcar têm sido afetado por políticas e acordos nacionais e internacionais desde o século passado. Atualmente os seguintes acordos internacionais influenciam a produção e o comércio mundial de açúcar: o NAFTA, o Mercosul, e a Organização Internacional do Açúcar (ISO).

Além destes, algumas políticas e acordos especiais entre países influenciam o mercado internacional do produto, dentre eles: o sistema de cotas de importação adotado pelos Estados Unidos (U.S. Sugar Program); os acordos especiais do Japão; e os subsídios à exportação e o sistema de cotas da União Européia com países da Ásia, Caribe e Pacífico (E.U. Sugar Protocol).

$\mathrm{Na}$ maioria dos países produtores de açúcar, o setor açucareiro é altamente regulamentado, seja através do controle da produção, da fixação dos preços dos produtos finais e da matéria-prima ou das cotas de importação e exportação. Normalmente, a proteção à produção (através de subsídios e tarifas) e os acordos internacionais possibilitam a produção em países sem vantagens comparativas, com custos de produção mais altos.

As cotas de produção são usadas para proteger as indústrias nacionais e conseguir a auto-suficiência, para se ter o controle sobre os preços finais (evitando superprodução, que implica em elevados subsídios, ou a falta do produto), ou mesmo 
para se manter a área agrícola em sintonia com a capacidade industrial, evitando falta ou excesso de matéria-prima.

Por sua vez, as cotas de importação ou a imposição de tarifas sobre o produto importado visam proteger as indústrias açucareiras locais da competição dos produtos importados de mais baixo preço. Esta política protecionista adotada por alguns países desenvolvidos tem o respaldo de países pobres (por exemplo os países da Ásia, Caribe e do Pacífico), o que acaba por fortalecê-la.

Por outro lado, embora os mecanismos de proteção utilizados visem proteger os preços e a produção local, a proteção prolongada pode resultar em ineficiências produtivas, que acabam sendo repassadas ao consumidor final. A seguir, são apresentados alguns instrumentos de políticas do setor açucareiro dos principais países produtores e consumidores.

\subsection{Estados Unidos}

A política americana adotada em relação ao açúcar é no sentido de proteger a produção doméstica da competição externa, sendo que os dois principais instrumentos de política identificados são a adoção de cotas de importação e a garantia de sustentação da renda dos produtores de açúcar, através de um preço de suporte básico (Rabobank, 1995).

Conforme Burnquist \& Piedade (1996), a comparação dos custos de produção de açúcar refinado em diversos países mostra que o açúcar americano não é competitivo internacionalmente: enquanto nos Estados Unidos o custo de produção de açúcar refinado de beterraba (que corresponde à maior parte do açúcar produzido naquele país) era de US\$20,6 centavos de dólar por libra-peso; na Tailândia era de US $\$ 14,0$ centavos de dólar por libra-peso; na África do Sul era de US\$13,5 centavos de dólar por librapeso; na Austrália era de US\$11,2 centavos de dólar por libra-peso; e, no Brasil era de US $\$ 11,0$ centavos de dólar por libra-peso.

A legislação básica seguida é a Food, Agriculture, Conservation and Trade Act, de abril de 1996, sendo que os principais elementos são as garantias de preço (associados 
aos programas de empréstimos) operando conjuntamente com os programas de flexibilização das áreas de plantio (Acreage Reduction Programs), objetivando que a produção se adapte às demandas do mercado.

O sistema de empréstimo com preços sustentados dá ao produtor a oportunidade de ofertar sua safra ao governo a uma dada taxa de empréstimo, que é vinculada aos preços de sustentação. Se os preços de mercado estiverem acima do preço associado à taxa de empréstimo, o produtor tem o direito de pagar seu empréstimo e vender a produção aos preços mais altos de mercado.

É interessante notar que quando o produtor de açúcar comercializa sua produção, o fornecedor da matéria-prima (cana-de-açúcar ou beterraba) participa dos retornos, já que a taxa de empréstimo é disponível para as usinas que atendam a exigência de pagarem um preço mínimo fixado para a cana-de-açúcar e para a beterraba.

A imposição de barreiras e a fixação de quotas e tarifas à importação têm sido o principal instrumento utilizado pelo governo americano para proteger a indústria nacional. As quantidades a serem importadas, bem como a cota específica de açúcar de cada país exportador e as tarifas impostas são determinadas anualmente, de forma a controlar a oferta e permitir que o preço de mercado seja suportado ao nível equivalente ao associado ao da taxa de empréstimo.

Segundo o Rabobank (1995), em 1983, a cota brasileira era de 329 mil toneladas (correspondendo a 12,33\% do total importado); em 1988 caiu para 137 mil toneladas (10,46\% do total); sendo que em 1994 passou a 142 mil toneladas $(13,67 \%)$. Para 1997/98, a quantidade de açúcar importada pelos Estados Unidos totalizou 1.600.000 toneladas, sendo que a maior cota foi da República Dominicana $(16,77 \%$ do total), sendo a cota brasileira (221.084 toneladas) a segunda maior, correspondendo a $13,82 \%$ do total (USDA, 1998) ${ }^{4}$.

Desta forma, as cotas têm sido usadas para suportar os preços domésticos no mercado americano em níveis mais elevados do que os do mercado mundiais, de forma a estimular a produção local.

\footnotetext{
${ }^{4}$ Conforme o site: http://www. fas.usda.gov
} 
O sistema variável de tarifas (Tariff Rate Quota), que incide sobre as importações, funciona da seguinte maneira: baseada no balanço entre a produção doméstica e a previsão de consumo, determinam-se as cotas dos países, sendo imposta uma primeira tarifa (que inclusive pode ser nula). A quantidade importada acima deste valor é sobretaxada de maneira suficientemente alta de forma a tornar as exportações para os Estados Unidos não lucrativas.

Existem mecanismos de "gatilho" na Tariff Rate Quota, que é acionado quando o diferencial entre a oferta e a demanda internas atinge um percentual pré-estabelecido. Neste caso, automaticamente são fornecidas cotas adicionais aos países exportadores, com tarifas fixadas de forma a permitir a importação.

Segundo o Rabobank (1995) a principal consequiência da política americana é o rápido desenvolvimento de adoçantes alternativos, principalmente o High Frutose Corns Syrup (HFCS), além de adoçantes não calóricos, tais como o aspartame, já que os altos preços do açúcar no mercado interno aumentam a lucratividade da produção de adoçantes alternativos. Atualmente, $50 \%$ do açúcar consumido nos estados Unidos é HFCS.

Em relação ao mercado de combustíveis, existem, conforme a Associação dos Produtores Autônomos de Álcool (ALCO, 1997), duas legislações básicas: a que regula a competição entre as empresas, a Petroleum Market Practices Act, que objetiva proteger os pequenos produtores do poder dos maiores; e a legislação ambiental, que ganhou importância a partir do Clean Air Act, de 1990.

Segundo a ALCO (1997), os 50 estados americanos consumiram, em 1997, 5,67 bilhões de litros de etanol, sendo que o mercado potencial para o etanol é da ordem de 45 bilhões de litros. A maior demanda por etanol é no inverno, devido aos problemas ambientais. A importação é taxada em US\$54 centavos de dólar por galão. A legislação americana permite a adição de até $10 \%$ de etanol na gasolina.

Quanto a produção, 95\% do etanol eram feitos, em 1997, a partir do milho, e o restante, do trigo, do arroz, da madeira e da batata. O programa de produção de etanol 
surgiu com o objetivo de estabilizar o preço do milho, além de gerar uma alternativa para a gasolina importada.

Conforme a ALCO (1997), embora não existam subsídios diretos para os produtores de milho produzirem etanol, o suporte do programa é feito através de um sistema de isenção fiscal no uso do produto como aditivo à gasolina. $O$ nível dos subsídios (que no início do Programa era de 60 centavos por galão, estando em 54 centavos por galão em 1997) foi aprovado até o ano de 2.007, sendo que a partir de 2002 deverá ser lentamente reduzido.

O valor de 54 centavos por galão implica num total anual de subsídios de US\$500 milhões de dólares, e ao mesmo tempo que este valor é considerado muito alto por uns, outros defendem sua manutenção, no que têm o apoio dos ecologistas, fazendeiros e trabalhadores, já que sem esse incentivo estima-se uma redução de $50 \%$ da produção de etanol.

Em relação à taxação dos combustíveis, existe um imposto federal (Excise Tax), um imposto estadual (que varia conforme o Estado), e os impostos municipais, que são aplicados somente em algumas cidades. A fim de se incentivar o uso do etanol, já que os combustíveis alternativos não são economicamente competitivos, existe uma redução no imposto federal (estabelecida pelo Clean Air Act, de 1990) quando o etanol é adicionado à gasolina: se a mistura contiver $10 \%$ de etanol ${ }^{5}$, os impostos passam de 18,4 centavos por galão de gasolina para 13 centavos por galão, o que representa $45 \%$ do custo do etanol contido na mistura.

Existe um programa de gasolina reformulada que exige, no mínimo, 2,8\% de oxigênio em peso, o que corresponde a $11 \%$ de $\mathrm{MTBE}^{6}$ ou $7 \%$ de etanol, em volume, sendo que já é estabelecido que 37 cidades devem usar este tipo de gasolina (esta proporção gera uma isenção de imposto da ordem de 4 centavos por galão).

É interessante notar que a descoberta de MTBE nas águas subterrâneas dos Estados Unidos, cujos efeitos de poluição são graves, impulsionou as definições

\footnotetext{
${ }^{5}$ A mistura de $10 \%$ permite a opção pela redução do Excise Tax ou compensação com o imposto de renda.

${ }^{6}$ Metil-tércio-butil-éter, aditivo derivado do petróleo.
} 
referentes à extinção de seu uso como aditivo. No Estado da Califórnia seu uso foi banido em março de 1999, sendo que o prazo estipulado para a extinção total não pode ultrapassar 31 de dezembro de 2002. ${ }^{7}$ Nesta mesma data iniciou-se naquele Estado um estudo completo sobre os impactos ambientais do etanol como aditivo oxigenado na gasolina (que deve estar concluído em 31/12/1999). Caso o etanol seja considerado um substituto aceitável ao MTBE, a Comissão de Energia da Califórnia deverá definir os passos para viabilizar a produção de etanol.

Além disso, existem definições no sentido de não mais se usar o MTBE em todos os Estados Unidos, o que espera-se aconteça nos próximos anos. Embora exista a hipótese de uma reação da indústria petrolífera americana que dificulte o processo, o mais provável é que o etanol passe a ser usado como aditivo na gasolina, o que significa a abertura de um grande mercado para o etanol.

\subsection{União Européia}

A União Européia ${ }^{8}$ era, em 1994, o maior consumidor mundial de açúcar, sendo responsável por $12 \%$ do consumo mundial. A produção de açúcar de beterraba é fortemente suportada pela Política Agrícola Comum (Common Agricultural Policy), sendo que os efeitos desta política alteraram sua condição de maior importador de açúcar no início dos anos 70 para a de maior exportador mundial (Rabobank, 1995).

Basicamente a intervenção no setor açucareiro é feita através de quotas de produção de açúcar, de um sistema de preços diferenciado e de acordos de importação e exportação com outros países.

Pelo sistema de quotas de produção (que são fixadas anualmente), cada País membro recebe determinada cota $\mathrm{A}$ e cota $\mathrm{B}$ a ser produzida de açúcar e de isoglucose HFCS, que juntas indicam a quantidade total a ser produzida e vendida diretamente no mercado comum europeu ou exportada (com elevados subsídios). Cada País então aloca

\footnotetext{
${ }^{7}$ Informação UNICA, ano 2, №19, abril de 1999.

${ }^{8}$ Compreende os seguintes países: Bélgica, Dinamarca, França, Alemanha, Grécia, Irlanda, Inglaterra, Itália, Holanda, Portugal e Espanha.
} 
as cotas para seus produtores, que por sua vez estipulam a matéria-prima necessária para a produção, negociando com os agricultores através de contratos (Rabobank, 1995).

O sistema de preços é usado para reduzir a competição do produto importado no mercado interno e assegurar retornos adequados para os usineiros e agricultores, sendo que os preços para a beterraba e para o açúcar são fixados anualmente.

Diversos acordos internacionais, de difícil contestação no âmbito da OMC, vêm sendo assinados entre a União Européia e países pobres da Ásia, Caribe e Pacífico (ACP), nos quais ela reserva cotas de importação de açúcar destinadas a estes países. Desta forma, a União Européia oferece apoio político e financeiro através do comércio (já que o acesso ao seu mercado representa ajuda financeira importante para estes países), e acaba por excluir os demais países produtores de seu mercado.

Porém, estes acordos fazem com que os países ineficientes (que contam com a proteção dos países ricos através do acesso ao seu mercado de preços mais altos), se mantenham atrasados tecnologicamente, e que haja desperdício dos recursos envolvidos nas transações, que seriam melhor aplicados se fossem dados diretamente a estes países.

\subsection{Europa Central e Antiga União Soviética}

A região da Europa Central e da antiga União Soviética é muito importante para o mercado mundial de açúcar, já que ela representava, em 1993, 10,1\% da produção mundial, 13,7\% do consumo e 32,5\% das importações (Rabobank, 1995).

O objetivo desses países é atingir a auto-suficiência, sendo que as políticas variam conforme o país. Alguns países da Europa Central (tais como a Polônia) estão aderindo ao modelo da União Européia (introduzindo o sistema de cotas de produção e cotas de exportação subsidiadas pelo governo), para terem acesso ao mercado da União Européia.

A Federação Russa reduziu as importações subsidiadas em 1994, a despeito do efeito sobre as importações de açúcar bruto de Cuba ou sobre a sobrevivência da indústria local. Muitas companhias estão em processo de privatização, embora este 
processo seja bastante dificultado pela ausência de políticas consistentes e de uma estrutura de direitos de propriedade adequada.

Entre 1961 e 1992 havia um acordo bilateral entre Cuba e a Antiga União Soviética, a qual se comprometia a comprar somente o açúcar cubano, causando inclusive instabilidade no mercado aberto de açúcar, do qual era antiga compradora. Conforme o acordo, Cuba fornecia açúcar em troca de óleo, sendo que era uma forma da União Soviética subsidiar implicitamente a economia cubana. Como algumas vezes as importações soviéticas excediam a necessidade interna, havia uma reexportação para o mercado mundial.

A partir de 1992, a Antiga União Soviética tem reduzido as importações e procurado a auto-suficiência. Com a introdução das condições de livre-mercado, ocorreu uma mudança na distribuição do açúcar: $25 \%$ da produção é usada para suprir as reservas nacionais, as quais são distribuídas para os consumidores através das organizações governamentais; os restantes $75 \%$ são vendidos aos consumidores diretamente pelos produtores de açúcar (Rabobank, 1995).

\subsection{Cuba}

Embora por muito tempo Cuba tenha sido o maior exportador mundial de açúcar, até os dias atuais ainda não implementou uma política consistente para o açúcar.

Desde 1961 a maior parte de suas exportações dirigiam-se à antiga União Soviética, através de um acordo bilateral, sendo que a União Soviética provinha subsídios implícitos à economia cubana, já que o preço pelo açúcar era de 3 a 4 vezes superior aos preços mundiais.

Com a quebra da União Soviética, Cuba enfrenta sérios problemas: desde 1989 os subsídios foram reduzidos e as exportações para a União Soviética diminuíram de 4,3 milhões de toneladas em 1989 para 0,4 milhão em 1993 (Rabobank, 1995). Atualmente a produção cubana é da ordem de 3,5 milhões de toneladas de açúcar.

Para exportar para outros países, o País tem de enfrentar a concorrência de outros produtores de açúcar, além de se deparar com preços mundiais significativamente 
menores. Algumas medidas foram tomadas pelo governo cubano para tentar enfrentar a nova situação, tais como tentar atrair capital externo de investimento para estimular a indústria e negociações com a China no sentido de exportar açúcar e importar alimentos e roupas.

\subsection{México}

$\mathrm{Na}$ administração do Presidente Carlos Salinas a economia mexicana passou por um programa de reformas profundas, que incluíram o setor agrícola, e mais especificamente a privatização das usinas de açúcar e a liberação de preços do produto. Durante o período de privatização, a indústria açucareira mexicana era a maior agroindústria do país, participando com 0,9\% do Produto Interno Bruto em 1990, além de ser uma das maiores fontes de emprego mexicanas (Kuezler, 1995).

Em relação à intervenção estatal, ela era bastante intensa e abrangia proteção aos produtores domésticos através do controle da importação de açúcar, da imposição de pesadas taxas sobre o produto importado, ou da combinação de ambos. Além disso, ela se estendia ao longo de toda a cadeia produtiva, incluindo subsídios para garantir o suporte de preços para os produtores de açúcar e de cana-de-açúcar, o controle do comércio doméstico e internacional, e o estabelecimento do preço final do açúcar ao consumidor.

Conforme Kuezler (1995), o auge da intervenção se deu quando o setor público detinha $75 \%$ das usinas de açúcar do País (sendo que na década de 70 o setor privado é que detinha este percentual), através de um empreendimento governamental (AZUCAR) criado para coordenar o desenvolvimento da indústria açucareira, controlar a administração das usinas estatais e atender os objetivos de distribuição e comercialização do açúcar.

Desta forma, o AZUCAR era ao mesmo tempo monopolista e monopsonista, já que comprava todo o açúcar das usinas (por um preço de liquaidação) e o distribuía para o consumo industrial e de varejo. Todos os custos associados à estocagem e distribuição 
ao longo do ano eram de responsabilidade da estatal, e só ela podia importar açúcar para suprir a demanda interna.

Segundo Kuezler (1995) a regulamentação excessiva e as restrições impostas pelo governo favoreciam a criação de estruturas de mercado ineficientes. O autor cita como exemplos a proibição governamental da adoção de integração vertical, impedindo que as usinas assegurassem oferta de cana mais conveniente para sua produção, e o preço mínimo de suporte recebido pela cana-de-açúcar, que não provinha incentivos para fornecimento de cana de melhor qualidade: os produtores recebiam um preço uniforme equivalente ao teor de sacarose médio obtido pela usina, representando um subsídio cruzado dos produtores de teor de sacarose mais altos para os de mais baixo.

Outro fato relatado pelo autor é que o preço da cana-de-açúcar e o do açúcar eram completamente não relacionados: enquanto o preço da cana-de-açúcar era indexado ao índice de preços da Cidade do México, o do açúcar era estabelecido de maneira arbitrária. Esta política teve efeitos severos sobre as margens operacionais das usinas, e desestimulou investimentos de longo prazo, resultando numa obsolescência tanto das usinas como dos canaviais, com conseqüente queda de produtividade, redução da quantidade disponível de cana-de-açúcar e ociosidade das usinas.

Em 1987 o Governo Mexicano resolveu reduzir sua intervenção no setor açucareiro, iniciando com a privatização das usinas de açúcar, reduzindo sua participação em 50\% da produção, sendo que os três objetivos principais eram: não criar monopólios regionais; não prejudicar a situação financeira da AZUCAR; e, reduzir significativamente os subsídios canalizados àquelas usinas.

Um ano mais tarde, decidiu privatizar todas as usinas de açúcar e implantar um processo de desregulamentação profundo. Nesta época, o Governo Mexicano resolveu se retirar completamente da produção e comercialização do açúcar, sendo que a partir de então aboliu a taxa de $50 \%$ sobre as vendas de açúcar (que eram cobradas sobre as vendas que não fossem feitas pela AZUCAR), e passou a permitir a integração vertical com os consumidores de açúcar, na tentativa de criar canais de comercialização privados para as usinas. 
Em relação aos preços, foi eliminado o preço mínimo de suporte aos produtores de cana, sendo que o pagamento da cana passou a ser feito baseado na quantidade de açúcar contido na cana (açúcar recuperável). Desta forma, os subsídios aos produtores menos eficientes foram eliminados, objetivando proporcionar incentivos para produção de cana de melhor qualidade, já que a renda do produtor passou a depender do açúcar recuperável contido na sua própria cana.

Quanto às taxas sobre o açúcar importado, elas passaram a ser variáveis conforme sua relação com o preço de referência: se os preços do produto importado forem menores que o de referência, o importados pagará uma tarifa equivalente à diferença entre os preços; em caso contrário, a tarifa será zero. Segundo Kuezler (1995), embora teoricamente este sistema sirva para isolar os produtores internos das distorções dos preços internacionais do açúcar, a definição deste preço traz o risco inerente de tornar uma operação muito arriscada ou atrativa, dependendo do comportamento dos preços internacionais.

Quanto à política de preços domésticos, foi decidido vincular o preço do açúcar e da cana-de-açúcar de forma que o preço da cana será uma proporção fixa do preço do açúcar da usina. O autor considera que eventuais problemas possam ser corrigidos com o lançamento da nova bolsa de mercadorias (Fideicomiso para el ordenamiento del Mercado Azucarero, FORMA), que reduzirá as oscilações dos preços através de contratos futuros.

Desta forma, a liberalização do setor procurou corrigir as custos excessivos ao setor público gerados pela existência do monopólio privado do açúcar (AZUCAR), que além de não promover os incentivos necessários ao desenvolvimento do setor, inibiu sua competição. A eliminação dos subsídios existentes marcou o início de uma nova forma de política governamental, encorajando a produtividade e a eficiência, realocando os recursos do Estado para as áreas de desenvolvimento social, saúde e educação.

Carvalho ${ }^{9}$ salienta que com a criação do NAFTA surgiram duas alterações importantes no mercado de açúcar mexicano. Primeiramente o aumento do consumo de

\footnotetext{
${ }^{9}$ CARVAlHO, L.C.C. Comunicação Pessoal, 1999.
} 
HFSC americano, que provocou excedentes exportáveis de açúcar de 1 milhão de toneladas, provocando queda nos preços internos, que estão praticamente a metade do valor dos custos de produção. Este fator, aliado a questão da poluição ambiental, fizeram com que o País iniciasse um programa para adição de álcool anidro na gasolina.

A segunda alteração decorrente do NAFTA é que provavelmente, no médio prazo, os mexicanos conquistarão o mercado americano.

\subsection{China}

As políticas adotadas pelo Governo Chinês referentes ao setor açucareiro são, conforme o Rabobank (1995), a de suporte de preços e restrição à importação, com o objetivo de conseguir a auto-suficiência, já que a China é o maior importador de açúcar dentre os países em desenvolvimento.

Entre 1963 e 1988 o governo manteve o preço do açúcar inalterado, o que desencorajou os produtores a plantarem cana-de-açúcar ou beterraba, o mesmo não ocorrendo com o consumo, que aumentou significativamente nos anos 80 .

Para incentivar a produção, a partir de 1988 o governo aumentou os preços da cana-de-açúcar e da beterraba, o que resultou um aumento da área plantada de $40 \%$ entre 1988 e 1993. Porém, a liberdade dos preços internos fez com que os custos relativamente altos do setor açucareiro tornassem sua produção não competitiva, e os produtores de cana e de beterraba mudaram sua produção para outras culturas mais rentáveis.

Segundo Rabobank (1995) existe um sistema triangular entre a produção de cana-de-açúcar ou beterraba, a fabricação do açúcar, e a sua comercialização: enquanto as safras são estabelecidas pelo Ministério da Agricultura, as usinas e destilarias funcionam subordinadas ao Ministério da Indústria, e a comercialização é de responsabilidade do Ministério do Comércio Interno. Isto causa um sistema de débitos entre os três ministérios, que leva a problemas entre eles.

Em relação às políticas de preços, os preços ao produtor têm estado livres refletindo as condições de mercado. Embora o objetivo seja a auto-suficiência, a urbanização da população está aumentando, com conseqüente aumento das necessidades 
de importação, o que faz o governo constantemente aplicar as quotas de importação para evitar importações excessivas de açúcar.

É interessante notar o grande crescimento observado do consumo de sacarina na China, que levou o governo limitar sua produção de forma a incentivar o uso do açúcar. Além disso, a União Européia estabeleceu um convênio com a China para que esta produza 600.000 toneladas de ETBE para ser misturada à gasolina. ${ }^{10}$

\subsection{Japão}

O Japão é um grande importador de açúcar (suas importações representaram $5,59 \%$ do total mundial importado no ano safra 1996/97, conforme Burnquist \& Bacchi, 1997), embora a importância das importações de açúcar venha declinando em relação à produção doméstica, como resultado do aumento da produção de adoçantes e da queda do consumo de açúcar.

Segundo o Rabobank (1995), os preços ao consumidor são mantidos acima dos preços mundiais através da imposição de tarifas ao açúcar importado, e devido ao complexo sistema de taxas existentes no processo produtivo: são pagos subsídios para os produtores de açúcar bruto, a fim de incrementar os preços pagos pelas refinadoras.

Desta forma, o nível alto dos preços suportados pelo governo incentivou o desenvolvimento da indústria de HFCS, o que resultou, conforme comentado anteriormente, no declínio das importações de açúcar bruto, e numa capacidade ociosa das refinarias de açúcar do País.

Em relação à produção de matéria-prima (cana ou beterraba), existe um sistema no qual o governo assegura a compra do açúcar das usinas de açúcar a dado preço, desde que as mesmas tenham comprado a matéria-prima pelo preço mínimo estabelecido.

Conforme o Rabobank (1995), a fim de garantir que o açúcar nacional possa competir com o importado (de mais baixo preço), o governo revende o açúcar às usinas por um preço menor do que comprou, sendo a diferença oriunda de alocações

${ }^{10}$ Conforme CARVALHO, L.C.C. Comunicação Pessoal, 1999. 
governamentais e de um fundo financiado pela sobretaxa imposta às importações de açúcar bruto.

\section{8 Índia}

A Índia é o maior produtor ${ }^{11}$ e consumidor mundial de açúcar, sendo responsável, no ano-safra 1996/97, por $12,37 \%$ do consumo e por $12,93 \%$ da produção mundiais. Além disso, foi o País que apresentou as maiores taxas médias de aumento da produção e na exportação durante o período de 1993/94 a 1996/97: respectivamente $10,71 \%$ e $157,55 \%$ (conforme Burnquist \& Bacchi, 1997).

O setor de açúcar é um dos mais regulados na Índia, que procura a autosuficiência através de um sistema de suporte aos preços e de uma política de importação restritiva, já que em termos internacionais a indústria não é competitiva.

O mercado indiano de açúcar é dividido em dois setores, sendo que em um deles o preço do açúcar é taxado (levy sugar) e no outro é livre: o açúcar taxado é vendido através de um sistema distribuição pública a preços menores, para consumidores de renda mais baixa, e o açúcar livre é vendido em mercados abertos. A quantidade de açúcar que as usinas devem vender no mercado taxado varia ao longo do tempo, sendo que em 1997 era de 40\% (conforme o artigo "INDIA edges toward liberalization of its sugar industry", 1997).

Como o preço do açúcar no mercado taxado é menor que os custos de produção, deve haver uma diferença de preços bastante grande entre os dois mercados para que as usinas se mantenham solventes. Este sistema duplo de preços gera bastante descontentamento por parte dos usineiros, que se sentem instrumentos da política social do governo.

A situação dos usineiros se complica mais porque eles têm que comprar a canade-açúcar pelo preço mínimo ditado pelo governo, além de terem que seguir um cronograma de fabricação mensal estipulado, que nem sempre coincide com o que eles acham mais apropriado do ponto de vista mercadológico.

${ }^{11}$ Índia e Brasil disputam a liderança da produção mundial de açúcar. 
Segundo o referido artigo, os fornecedores de cana também demonstram insatisfação com alguns aspectos da intervenção, principalmente no que se refere ao sistema de licenças para a construção de novas usinas e para a expansão das existentes, que são controlados pelo governo. Eles alegam que se fosse permitida a instalação de novas usinas aumentaria a competição entre elas, melhorando o preço pago pela cana, e que a instalação de novas fábricas, mais modernas, permitiria a produção de açúcar com custos menores tanto para o mercado interno como para exportação.

Desta forma, ambos os lados pressionam por uma maior liberdade para a indústria açucareira na Índia, alegando que o modo mais eficiente de produzir o açúcar é num mercado livre.

Um primeiro passo para a liberalização foi dado ao se extinguir o monopólio privado existente nas exportações de açúcar: até 1997, somente uma companhia privada (Indian Sugar and General Industries Export/Import Corporation) podia fazer a exportação do produto, sendo que no início de 1997, o presidente indiano aprovou a descentralização das exportações de açúcar. Contudo, o governo ainda mantém o controle sobre a quantidade total a ser produzida para a exportação, além de permitir que somente empresas credenciadas façam a exportação.

Conforme o artigo INDIA edges toward liberalization of its sugar industry (1997), é interessante notar que enquanto a indústria era fortemente regulamentada pelo governo, as pressões para que se reduzisse a intervenção governamental era bastante intensa, agora que ela começa a se reduzir, as queixas são no sentido que ela está indo muito longe ou em direção errada.

Porém, este fato pode ser compreendido quando se pensa que uma indústria que cresceu e sofreu a intervenção governamental por mais de cinqüenta anos acaba adaptando-se a este ambiente, e passa a reconsiderar a remoção dos controles governamentais, principalmente naquelas questões de seu interesse.

Ainda segundo o mesmo artigo, os rumos a serem tomados pelo Governo Indiano são bastante importantes em relação à oferta de açúcar mundial. Embora pareça que ele tenda a diminuir seu controle, o Parlamento, em resposta às pressões das partes 
interessadas, parece não querer tomar decisões apressadas. Por outro lado, não é impossível que o Governo, após ter tomado algumas medidas liberalizantes, resolva não seguir adiante.

Desta forma, se a liberalização levar a preços menores e aumento da produção, o potencial Indiano como produtor mundial de açúcar não pode ser desconsiderado. Por outro lado, conforme o Rabobank (1995), resta a dúvida se o objetivo da auto-suficiência será atingido no longo prazo, já que o aumento do consumo está alinhado com o crescimento populacional verificado.

\subsection{Tailândia}

Em relação aos padrões mundiais, a indústria açucareira da Tailândia é relativamente eficiente, sendo que o País é um dos grandes exportadores de açúcar de cana do mundo e o nível de subsídios da produção açucareira é, em relação aos padrões mundiais, relativamente baixo (Rabobank, 1995).

O controle estatal sobre o setor açucareiro é feito através da fixação de preços domésticos e da imposição um sistema de quotas de produção. Em relação às cotas, as usinas têm cotas de produção individuais, e são requeridas à alocarem determinadas proporções de sua produção nos mercados doméstico e de exportação, conforme fixado pelo governo. As próprias usinas se encarregam das exportações, sendo que o açúcar é exportado através de licenças de exportação.

Conforme Rabobank (1995), os preços ao consumidor são fixados acima do preço mundial de mercado para a "quota doméstica A", de forma a dar suporte aos produtores e fornecedores . A cota "B" de açúcar é controlada pelo governo e vendida nos mercados internacionais, sendo que $70 \%$ da receita obtida vai para os fazendeiros e $30 \%$ para as usinas. A cota remanescente "C" não é regulada e é vendida livremente pelas usinas.

A garantia de preços para os produtores de cana é feita através de negociações entre o setor privado e o sistema de créditos subsidiados existentes. 


\subsection{Austrália}

A Austrália é um importante exportador de açúcar no mercado mundial, sendo que seus custos de produção estão entre os menores do mundo. Conforme Serodio (1999), na safra 98/99 a participação da Austrália no total das exportações mundiais foi a terceira maior (eqüivalendo a 12,7\%), sendo precedida pela União Européia $(15,6 \%)$ e pelo Brasil $(20,7 \%)$.

Existem duas regiões produtoras de açúcar (Queensland e New South Wales), sendo que o nível de regulamentação existente em cada uma delas são bastante distintos: enquanto na primeira existe o controle de preços e produção, na segunda a produção é feita em unidades menores, que operam num ambiente praticamente de livre mercado (Rabobank, 1995).

Em 1991 o Governo de Queensland fez uma importante reorganização das leis e da parte administrativa da indústria açucareira, decretando o Sugar Industry Act, objetivando: dar mais proteção aos fazendeiros face ao poder de compra das usinas; ordenar a expansão da capacidade conforme a infra-estrutura da indústria; coordenar o sistema de plantio e entrega dos produtores de cana; e, a preservação e aumento dos retornos das unidades industriais A compra do açúcar e o plantio são regulados, de tal forma que a Corporação estipula onde a cana será plantada e para qual usina será entregue. (Rabobank, 1995).

Foi criado um empreendimento coorporativo (Queensland Sugar Corporation) que se encarrega da compra da cana, pagamento dos fornecedores e da venda do açúcar.

\subsection{Brasil}

Para melhor compreensão do vulto e da relevância da intervenção estatal no setor sucroalcooleiro procurou-se fazer uma descrição cronológica das principais políticas governamentais adotadas e seus efeitos sobre o setor. 
É interessante notar que ao longo do tempo o setor sucroalcooleiro sempre viveu ciclos alternados de super produção e de super oferta ${ }^{12}$, fazendo que o processo intervencionista no setor tivesse como fundamento principal preservar o equilíbrio entre produção e consumo de açúcar, utilizando-se de dois instrumentos básicos: os Planos de Safra e as Políticas de preço e crédito.

Embora a intervenção do Estado na economia açucareira praticamente confunda-se com o próprio surgimento do setor, a análise do processo de intervenção neste trabalho começa com a criação do Instituto do Açúcar e do Álcool (IAA), em 1933, quando efetivamente se inicia o planejamento da produção pelo governo.

É interessante notar algumas fases distintas do processo intervencionista. Entre as décadas de 30 e 60, a intervenção foi profunda e intensa (estabelecendo cotas de produção, tabelando preços e ditando as normas de comercialização), e se instaurou a pedido dos próprios produtores, para resolver a grave crise de superprodução de 1930 . Nesta época foi criado o Instituto do Açúcar e do Álcool (IAA), para que se pudesse efetivar o planejamento da produção. $\mathrm{O}$ açúcar tinha um grande peso na pauta de exportações, e os riscos de mercado eram de certa forma controlados pelo governo, que garantia a comercialização da produção.

Uma segunda fase pode ser identificada na década de 70, quando a intervenção ainda era forte, continuavam as cotas de produção e os preços estabelecidos pelo governo, sendo que este almejava o aumento das exportações, dadas as condições favoráveis no mercado externo. Nesta época, tanto a produção como a demanda foram estimuladas pelo governo. Houve programas objetivando a melhoria da produtividade e modernização da área agrícola e do parque industrial, além de incentivos para relocalização e fusões das unidades, visando aumentar a competitividade externa. Iniciou-se o Programa Nacional do Álcool (Proálcool), primeiramente com o incentivo à produção de álcool anidro, com as regras de comercialização e produção bem definidas, preservando ainda os produtores dos riscos do mercado.

\footnotetext{
${ }^{12}$ Por exemplo, veja que em menos de dez anos (entre as safras de 1989/90 e 1998/99) o setor sofreu duas graves crises assimétricas: a primeira de desabastecimento de álcool combustivel; e a atual, de excedentes de álcool e de açúcar.
} 
No início da década de 80 , na fase final de instalação do Proálcool, inicia-se uma nova fase da intervenção estatal, já que os recursos governamentais para programas de investimentos começam a se esgotar. Nesta época os indicadores macroeconômicos do País eram desfavoráveis, levando a uma política de contenções da gastos públicos. Algumas destilarias que contavam com recursos governamentais para finalizar seus projetos acabaram não conseguindo obtê-los, atrasando a implantação dos mesmos. No final de 1989 as exportações de açúcar, que até então eram feitas pelo Instituto do Açúcar e do Álcool, foram privatizadas.

No início dos anos 90, já na segunda fase do Proálcool, a de carros movidos a álcool hidratado, com a demanda deste produto super aquecida devido a plena utilização deste combustível, ocorreu a crise de desabastecimento do produto, comprometendo intensamente o futuro do Programa. O descompasso entre a oferta e a demanda, o início de problemas entre o setor privado e o governo, e a abertura comercial iniciada pelo governo Collor evidenciaram a necessidade de um novo modelo de intervenção estatal no setor.

Desta forma, a última fase da intervenção, do início dos anos 90 até os dias atuais, caracteriza-se pela redução drástica da ação estatal, e pela constatação de que não é mais possível o governo atuar nos moldes anteriores, já que o ambiente institucional é completamente distinto, exigindo outro tipo de ação do Estado. A saída do governo (que liberou os preços e a comercialização dos produtos sem um mínimo de regulamentação), é feita num momento de super oferta dos produtos, estando o setor mergulhado numa crise sem precedentes. Os produtores, que até a fase de intervenção anterior tinham um mercado garantido pelo governo, passaram a operar num mercado super ofertado, de alto risco. 


\subsubsection{A década de 30: o início da intervenção estatal e a criação do Instituto do}

\section{Açúcar e do Álcool (IAA)}

No início da década de 30 a situação da agroindústria canavieira era particularmente vulnerável, devido a grande depressão mundial de 1929 e ao aumento da capacidade agrícola e industrial brasileiras ocorrida no início da década de 20.

Nestas condições, conforme salientado em Szmrecsányi (1979), a intervenção governamental no setor açucareiro se instaurou a pedido dos próprios produtores, com o propósito de resolver os problemas de excesso de oferta e de reorganizar os mercados internos.

Em junho de 1933, através do Decreto № 22.789 , foi criado o Instituto do Açúcar e do Álcool (IAA) cujos principais objetivos eram resolver o problema de superprodução da agroindústria açucareira, através do planejamento e controle anual da produção, adequando-a às necessidades de consumo interno e externo. Além disto, pretendia fomentar a produção de álcool combustível no País.

A principal atribuição do IAA, e que afetava diretamente o setor era a determinação dos limites de produção de álcool e açúcar de cada usina, que seria determinado com base nos estoques de açúcar existentes no País e nas estimativas das safras a iniciar-se.

A partir da criação do IAA diversas medidas foram tomadas na década de 30 objetivando o controle da oferta de açúcar, dentre elas: proibição da montagem de novas usinas, engenhos e banguês em todo o território nacional, sem sua prévia autorização; obrigatoriedade do registro de todas as fábricas de açúcar, álcool e aguardente; estímulo da produção de álcool motor; subordinação de todas as refinarias existentes ao Instituto, além de determinar a montagem e operação pelo IAA de refinarias para o beneficiamento do açúcar para mercado interno.

Além destas, a principal medida tomada durante este período foi 0 estabelecimento dos limites de produção de cada Estado produtor, que seriam fixadas a partir dos limites de produção equivalentes à média anual do último qüinquiênio, 
considerando também os estoques de açúcar existentes no País e as estimativas das safras de cana a iniciar-se.

Nesta primeira divisão, conforme Szmrecsányi (1979, p.194), as regiões Norte e Nordeste ficaram com $62,8 \%$ da produção total, enquanto aos Estados produtores da Região Sudeste (Minas Gerais, São Paulo e Rio de Janeiro) couberam 37,2\% do total. Pernambuco mantinha sua hegemonia, cuja cota de produção $(37,6 \%)$, era maior que os três Estados da Região Sudeste.

Além disso, visando amenizar os conflitos existentes entre usineiros e fornecedores, o governo intervém diretamente nas transações de compra e venda da cana-de-açúcar, através da Lei № 178 , que passou a regulamentar estas transações.

Em 1939 foram aprovadas as cotas de produção fixadas pelo Instituto para cada usina e engenho do País, sendo que a partir destas cotas individuais o IAA passou a formular anualmente os Planos de Safra. Também foram estabelecidos critérios objetivos para o aumento das cotas de produção de cada usina: se fosse verificado um aumento de produção de açúcar, o aumento correspondente de matéria-prima deveria guardar a proporção de $70 \%$ de cana de fornecedores, lavradores e colonos e somente $30 \%$ poderiam ser acrescidos aos canaviais das usinas. As divergências entre usineiros e fornecedores há muito se fazia notar o que é salientado em Ramos (1991, p.112):

“ ...os processos de concentração fundiária e de centralização industrial então em curso implicava num processo de proletarização dos trabalhadores da cana e do engenho, um processo ao qual estes procuravam resistir. Essa resistência evoluiu para o confronto direto, com seus agentes chegando a arrancar os trilhos das linhas férreas das usinas e depredar seus equipamentos. Não era somente em Pernambuco que esta situação havia atingido um estado de conflagração social. Também no Rio de Janeiro, onde, por razões específicas havia uma forte presença de pequenos fornecedores de cana, o processo de concentração fundiária levou a uma luta pela sobrevivência dos referidos produtores, que chegaram a ameaçar de atear fogo aos canaviais das usinas ...". 


\subsubsection{A década de 40: a criação do Estatuto da Lavoura Canavieira, a II Guerra} Mundial e a mudança da distribuição espacial da produção açucareira no País

\subsubsection{O Estatuto da Lavoura Canavieira}

Em 1941 foi promulgado o Estatuto da Lavoura Canavieira (Decreto-Lei № 3855, de 21 de novembro de 1941), que disciplinou rigidamente as relações entre fornecedores de cana e produtores de açúcar e álcool.

De uma forma sucinta, o Estatuto da Lavoura Canavieira conceituou a figura do fornecedor de cana; instituiu o cadastro de fornecedores; estabeleceu as condições de fornecimento, a garantia da moagem e a forma da pesagem da cana; impôs limitações e restrições às atividades agrícolas das usinas, disciplinou as cotas de fornecimento junto as usinas; estabeleceu critérios para fixação do preço da cana, e ditou normas para a composição dos litígios entre fornecedores e usineiros.

Das inovações trazidas pelo Estatuto duas são consideradas as mais importantes: a legalização da figura do fornecedor de cana e a cota de fornecimento a ele destinada. Foi considerado fornecedor todo lavrador que, cultivando terras próprias ou alheias, tivesse fornecido canas a uma mesma usina, diretamente ou por interposta pessoa, durante três ou mais safras consecutivas. Quanto às cotas de fornecimento, estipula que a quantidade de canas próprias das usinas pode chegar ao máximo de $60 \%$ da respectiva limitação, devendo ser os restantes $40 \%$ oriundos de canas de fornecedor.

Desta forma, os fornecedores de cana teriam a certeza de compra da sua cota de produção, pelo preço fixado pelo IAA ("calculado em correspondência ao preço do açúcar e do álcool, conforme se trate de cota para transformação em açúcar ou álcool, tendo em vista o coeficiente de rendimento industrial médio das fábricas de cada Estado, a riqueza em sacarose e a pureza das canas fornecidas". 13

\footnotetext{
${ }^{13}$ Guardadas as devidas proporções, nota-se semelhança com o atual modelo proposto (CONSECANA) de remuneração da cana-de-açúcar.
} 
O Estatuto procurava contemplar os fornecedores com uma assistência mais ampla, não só na parte técnica, como também no campo médico e educacional, visando a organização da vida rural, principalmente a dos pequenos proprietários rurais.

Contudo, conforme salientado em Queda (1972), a sensação que se tinha, no início da década de 70 , era que, embora o Estatuto contivesse medidas sociais importantes, e que seu objetivo fosse dividir com os fornecedores os benefícios com que a política açucareira vinha atendendo as usinas (através da garantia dos preços e consequiente estabilidade e da ampliação do crédito), ele havia falhado no sentido de que a parcela de produção de cana própria das usinas havia crescido mais do que a de fornecedores.

O fato da estrutura do fornecimento de cana ter sido organizada com base na pequena propriedade dificultou o surgimento de um grupo de pressão importante, já que o grande número de pequenos fornecedores impossibilitava sua organização. Conforme Jungmann (1971), os fornecedores não souberam tornar efetiva a lei, provavelmente por ser a categoria tão pulverizada: "Nos litígios entre usinas e fornecedores dificilmente outros fornecedores da mesma usina, interessados no processo, auxiliam os primeiros, porque não querem se indispor com a usina...".

\subsubsection{A II Guerra Mundial}

A eclosão da II Guerra teve impactos nos dois principais produtos da agroindústria canavieira, o açúcar e o álcool. Em relação ao álcool, um fator de caráter conjuntural, a escassez dos derivados de petróleo, principalmente a gasolina (que era praticamente toda importada do exterior), afetou fortemente a produção de álcool anidro, que passou a ser considerada estratégica dentro da economia nacional.

Entre 1937 e 1941 diversos incentivos foram concedidos, através de leis e decretos, visando o aumento da produção de álcool anidro no período considerado, sendo que em 1941 fixou-se em $20 \%$ o teor da mistura de álcool anidro à gasolina.

Em setembro de 1942, através do Decreto-Lei № 4.722, a indústria alcooleira foi declarada de interesse nacional, sendo estabelecido, pelo período de 4 anos, a partir 
da safra de 1943/44 "garantias de preços mínimos para o álcool e para as matériasprimas destinadas à sua fabricação", beneficiando os produtores que cumprissem os planos de produção estipulados pelo IAA.

Em relação ao açúcar, a II Grande Guerra não reabriu os mercados externos para o açúcar brasileiro, já que, ou por serem aliados da Alemanha ou por terem seus territórios invadidos pelos nazistas, a maioria dos países europeus interrompeu as importações das Américas devido ao alto risco existente nos transportes marítimos, sujeitos à ação dos submarinos inimigos. A Inglaterra e os Estados Unidos, por sua vez, optaram por redução do consumo e pelo abastecimento de outras fontes produtoras.

Em abril de 1945, estipulou-se que a liberação de cotas para novas usinas de açúcar só seriam emitidas condicionadas à instalação de destilarias anexas de álcool anidro. Mas as medidas tomadas não aumentaram a produção de álcool anidro neste período, devido a falta de benzol, usado como desidratante e cuja importação havia sido interrompida pela guerra, e as dificuldades de abastecimento do Centro-Sul com o açúcar proveniente do Nordeste, já que o risco no transporte marítimo devido aos ataques submarinos prejudicava também o intercâmbio de mercadorias entre o Sul e o Norte do País.

Desta forma, o Governo brasileiro, para suprir a demanda de açúcar existente no Centro-Sul, resolveu ampliar a produção açucareira em áreas anteriormente importadoras do Nordeste. Desta forma, a partir dos Planos de Safra de 1942/43 ocorreu uma grande inversão da política de contingenciamento da produção de açúcar, com o intuito de aumentar sua produção, sendo que o Governo Federal autorizou, em novembro de 1942, a liberação do regime de cotas e a montagem das novas usinas.

As diversas medidas tomadas a partir de então propiciaram não só o aumento da produção nacional de açúcar, como o deslocamento da produção do Nordeste para o Centro-Sul. As dificuldades de transporte do Recife para o Rio de Janeiro e Santos, aliadas a defasagem entre produção e consumo no Centro-Sul acabaram por exigir o fim do contingenciamento, favorecendo a expansão desta região 


\subsubsection{O Decreto-Lei № 9827 e a mudança da distribuição espacial da produção} açucareira

Com o fim da II Guerra, persistia a tendência de expansão da produção e os usineiros de São Paulo pressionaram o IAA para elevar suas cotas. Em setembro de 1946, o Governo Federal, através do Decreto-Lei № 9827, determinou uma revisão geral das cotas de produção de açúcar atribuídas a cada Estado.

É importante salientar que este Decreto subordinava a elevação dos limites estaduais de produção às necessidades de consumo regionais e não mais nacionais, ou seja, as cotas passaram a ser distribuídas em função dos déficits entre produção e consumo de cada Estado, estimulando o crescimento do número das usinas existentes em São Paulo, que apresentava produção inferior ao consumo.

Ramos (1991) salienta que a revisão geral das cotas baseada nas necessidades de consumo regionais e não mais nacionais foi resultado de uma forte pressão dos usineiros paulistas (que quase levou a extinção do IAA), em resposta à tentativa do Instituto de controlar a sua expansão. A partir da "liberação" da produção paulista, o problema enfrentado pelo IAA, nos anos seguintes, foi justamente procurar conter sua expansão.

Conforme este autor, embora o Estatuto da Lavoura Canavieira estipulasse que somente se poderiam constituir usinas com "absoluta separação entre a atividade agrícola e industrial", o Decreto-Lei № 9827 permitia uma flexibilidade que iria permitir a expansão paulista, já que embora estipulasse que as usinas poderiam utilizar, com lavouras próprias, até 50\% (cinquienta por cento) dos aumentos de cotas que lhes fossem concedidos, se o Instituto constatasse a falta de capacidade de produção dos fornecedores das usinas já existentes para a utilização das cotas de fornecimento, elas seriam atribuídas às usinas para aproveitamento com lavouras próprias.

Desta forma, para as usinas já existentes era possível ampliar sua produção com canas próprias. Para as usinas em constituição, não havia impedimento para que os donos de terras se tornassem produtores de açúcar; sendo assim, os proprietários de terras iam tornando-se usineiros, sendo que a "absoluta" separação entre atividade 
agrícola e industrial, conforme estipulado no Estatuto da Lavoura Canavieira, sucumbia à realidade.

Conforme Queda (1972): “... O grande salto quantitativo e qualitativo do setor industrial das usinas paulistas se dá na safra de 1947/48. O número de usinas em São Paulo cresce lenta mas constantemente até aquela safra: de um total de 20 na safra de 1929/30, passa para 34 na safra de 1940/41 e 42 na safra de 1946/47. Porém, na safra seguinte, a de 1947/48, o número se eleva para 71 usinas...". A Figura 1 (elaborada a partir de Queda, 1972) traz a evolução do número de usinas em São Paulo e Pernambuco.

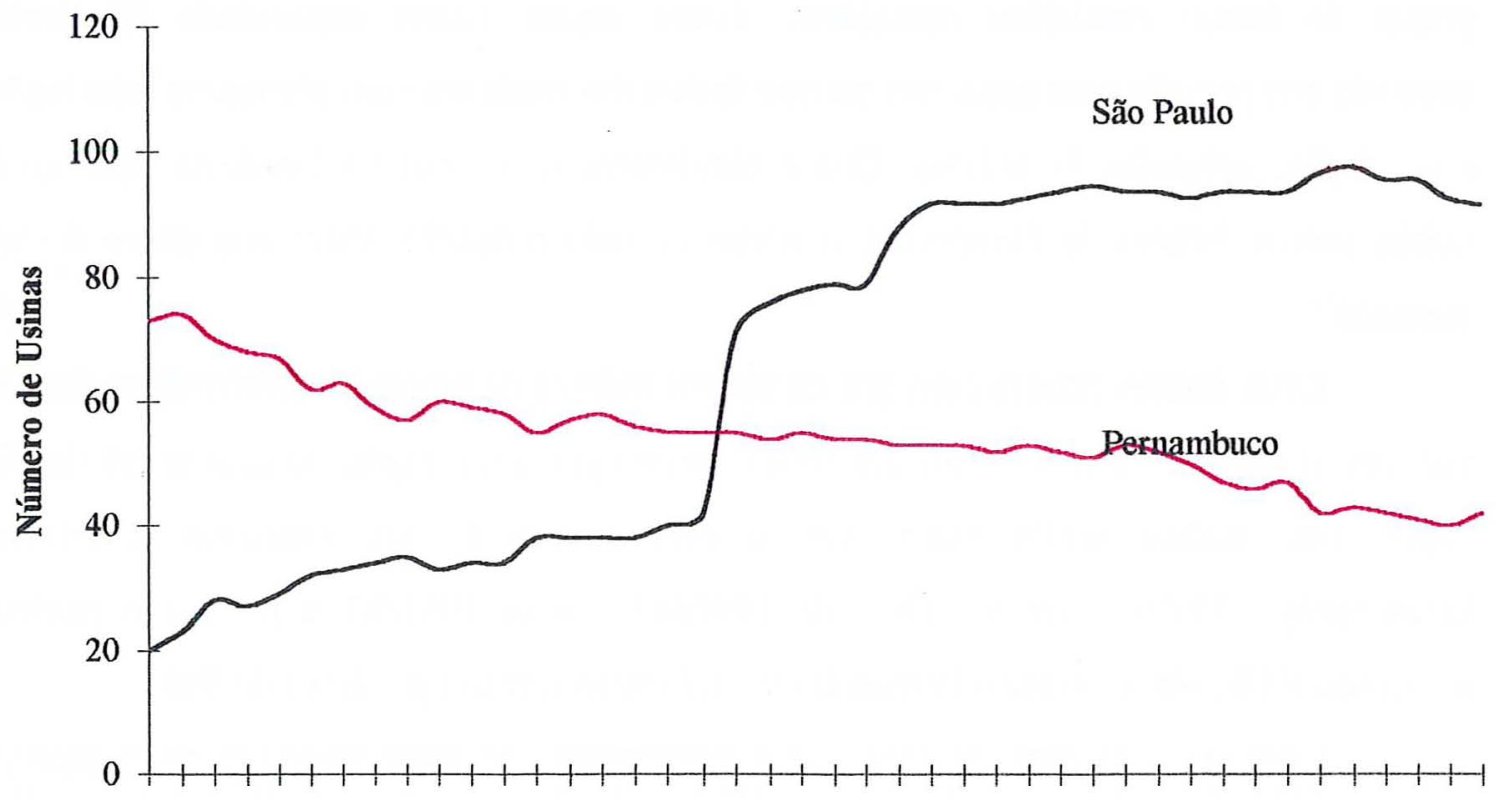

1929/30 1933/34 1937/38 1941/42 1945/46 1949/50 1953/54 1957/58 1961/62 1965/66 1969/70

Safras.

Figura 1 - Evolução do número de usinas: Estádos de São Paulo e Pernambuco

Diversos autores, entre eles Szmrecsányi (1979), Queda (1972) e Gnaccarini (1972) salientam que o aspecto mais importante a ser destacado era a transferência vultosa e irreversível da distribuição espacial da produção açucareira do País. Os dados apresentados em Szmrecsányi (1979) reforçam esta afirmativa: os aumentos concedidos 
aos estados do Centro-Sul, em 1946, fizeram sua participação passar de 39,9\% (limite permitido até a safra de 1944/45) para 46,8\%, sendo que merecem ser salientados o avanço de São Paulo, cuja participação passou de $17,6 \%$ para $22,2 \%$ e a diminuição da participação de Pernambuco, que se alterou de $37,7 \%$ para $28,9 \%$.

Em relação à transferência da produção do Nordeste para o Centro Sul, o autor observa que as condições sócio-econômicas tão divergentes entre as duas regiões também a influenciaram, talvez até de forma mais importante que o Decreto-Lei № 9827. Pina (1972, p.41) afirma que o referido decreto beneficiou o produtor do Sul, “... graças às (suas) condições peculiares, como sejam: maior capacidade financeira, mercado em posição vantajosa, um parque industrial moderno com eficientes instalações e condições agrícolas favoráveis. Quase totalmente o reverso do Nordeste, que ainda exibia outros índices desfavoráveis, a começar pelo reduzido poder aquisitivo do seu mercado".

Estes fatores faziam com que os custos médios de produção do Nordeste fossem maiores, o que somados ao custo dos fretes, privilegiavam a expansão açucareira de São Paulo, que acabou sendo maior que o crescimento de seu consumo. Conforme Szmrecsányi (1979), entre as safras de 1946/47 e a de 1951/52, a produção paulista aumentou $84 \%$, ultrapassando Pernambuco, até então o maior produtor do País.

Contudo, este autor destaca que o crescimento do setor como um todo, embora induzido pelos estímulos governamentais, não era somente um crescimento artificial, já que havia um aumento efetivo do consumo interno, decorrentes do crescimento da população e dos processos de urbanização e industrialização, que aumentavam a demanda de açúcar através das fábricas de bebidas, alimentos, etc.

Uma das consequiências do Decreto-Lei № 9827 foi uma superprodução de açúcar, que em parte foi absorvida pela exportação do produto a preços compensadores (já que os produtores da Europa e do Oriente ainda não haviam se reestabelecido dos efeitos da guerra), mas que não era suficiente para escoar os estoques e solucionar o problema de excesso de matéria-prima disponível. 
A partir da recuperação dos centros produtores internacionais de açúcar, os preços no mercado externo começaram a baixar, tornando as exportações gravosas, que passaram a depender de medidas protecionistas para se manterem.

Em janeiro de 1948, o IAA criou o Fundo de Compensação dos Preços do Açúcar, com o qual subsidiaria as exportações (cobrindo as diferenças de preços entre o mercado interno e externo) com os recursos arrecadados por uma sobretaxa a ser cobrada em cada saco de açúcar fabricado no País. Estes recursos seriam destinados também para financiar a produção de álcool, para dar vazão ao excedente da cana-de-açúcar existente.

Procurando resolver o problema de excesso de matéria-prima e do déficit do balanço de pagamentos (em grande parte causados pela importação de gasolina automotiva), em 1948 o Governo Federal novamente voltou a estimular a produção de álcool carburante. Segundo Szmrecsányi (1979), desta vez os objetivos foram plenamente atingidos já na safra 1948/49.

\subsubsection{A década de 50: a consolidação da produção do Centro-Sul}

A década de 1950 foi marcada pela expansão da produção, incentivada pelo IAA, de forma a atender o consumo crescente. A notável expansão do mercado interno brasileiro neste período, devido a grande urbanização e industrialização, fez com que a demanda pelo açúcar aumentasse, com conseqüente expansão da agroindústria canavieira.

Ao tratar da expansão da produção verificada na década de 50, Ramos (1991) salienta que o problema fundamental do Instituto durante os anos 50 foi o de controlar a expansão sulista ou, visto de outra forma, a sustentação da produção pernambucana, salientando que o IAA não mais conseguiria impor o contingenciamento que havia conseguido no final dos anos trinta e na primeira metade da década de 40. A pressão exercida pelos usineiros paulistas era bastante forte, sendo que inúmeros documentos legais foram emitidos a fim de revisar ou mesmo revogar judicialmente as resoluções referentes às cotas dos Estados. 
A hegemonia dạ região Centro-Sul e especialmente a de São Paulo ficou oficialmente reconhecida, quando, em dezembro de 1957, o IAA elevou a produção global do país, repartindo-o proporcionalmente à maior produção alcançada por cada usina entre as safras de 1951/52 e 1956/57.

Entre as safras de $1952 / 53$ e a de 1954/55 começaram a surgir excedentes de produção, fazendo com que o IAA aumentasse consideravelmente as exportações do produto, embora os preços internacionais estivessem bastante deprimidos. Porém, nos anos de 1954 e 1955 a situação piorou devido aos estoques mundiais crescentes oriundos da superprodução de açúcar mundial.

A situação de excesso de produto não se agravou mais devido a quebra de safra ocorrida em 1956/57 e ao aumento do consumo decorrente da nova onda de industrialização e urbanização do governo Juscelino Kubitschek.

Na safra 1958/59 a produção aumentou de 20\% em relação à anterior. O destino dado ao excedente era a exportação, o que, se de um lado era feito a preços externos bastante baixos, de outro convinha ao Governo Federal, às voltas com problemas de déficit do balanço de pagamentos. Conforme Szmrecsány (1979) a receita cambial gerada pelo açúcar em 1957 representou 5\% do valor total das exportações brasileiras, e, em 1958 esta participação só foi menor que a do café e a do cacau, que eram os dois principais produtos de exportação.

Mas, embora representando entrada de divisas para o País, as exportações de açúcar eram gravosas, e o IAA, devido a grande quantidade exportada, não tinha mais como subsidiá-las. Desta forma, o Poder Público passou a fornecer os recursos para os subsídios às exportações, o que implicava em custos sociais, que foram menosprezados em virtude das dificuldades do balanço de pagamentos.

\subsubsection{Políticas de preços}

As políticas de preços praticadas pelo Instituto do Açúcar e do Álcool também são consideradas como um dos fatores responsáveis pelo deslocamento da produção açucareira da Região Nordeste para São Paulo. Conforme Gomes (1979) as políticas de 
preços realmente foram efetivas a partir de 1943, já que até então se assemelhavam a uma política de preços mínimos, onde o governo estabelecia limites inferiores para os preços do açúcar, e valia-se de mecanismos fiscais para evitar que os preços caíssem abaixo daquele valor.

Em 1943, segundo o autor, o governo fixou os preços na condição "FOB Nordeste"., ou seja, na condição "posto no navio" nos portos nordestinos dos Estados produtores, sendo que para os demais (com exceção do Rio de Janeiro, que também era exportador), os preços ao consumidor eram estabelecidos acrescentando-se os custos de transporte do produto do Nordeste até os Estados produtores.

Com esta sistemática de preços os produtores de açúcar do Centro-Sul eram beneficiados, já que o açúcar da região Nordeste (responsável na época pela maior parte do açúcar consumido no País) chegava ao consumidor sulino por um preço mais alto, já que incorporava os custos de produção e os de transporte. Esta situação gerou protestos dos produtores nordestinos, já que levava à expansão das regiões produtoras competidoras do Nordeste, e confrontava-se com os principais objetivos da intervenção, que era, na sua origem, proteger a agroindústria açucareira nordestina.

Desta forma, em 1951 esta sistemática de preços foi alterada, passando a ser estabelecido um preço de liquidação único para todos os produtores do País (baseado no preço fixado para o Nordeste) e outro chamado preço de faturamento. Neste sistema, cobrava-se uma taxa dos produtores do Centro-Sul, revertida em favor dos produtores nordestinos. As diferenças verificadas entre os dois preços eram recolhidas no Banco do Brasil, para a criação de um Fundo de Reequipamento, administrado pelo IAA.

Conforme Szmrecsány (1979, p242) os recursos arrecadados seriam utilizados, dentre outras coisas, para “... a) compensação de fretes para permitir a equivalência de preços nos diversos centros consumidores, qualquer que fosse a procedência do açúcar; b) financiamento da produção e ampliação do parque açucareiro e alcooleiro; c)custeio de insumos modernos; ..."

Desta vez, os produtores paulistas é que se mostraram insatisfeitos com esta política de "sobre-preço", o que fez com que ela fosse revogada em 1965, com a 
promulgação da Lei № 4870, em dezembro de 1965. Desde 1967 (quando entra em vigor o estabelecido na referida Lei), os preços do açúcar passaram a ser estabelecidos a partir dos custos industriais médios de cada região produtora, sendo, portanto, maiores na região Nordeste, que apresentava custos de produção mais elevados que os estados do Sul.

Esta sistemática de preços, que implicava em fixação de preços de açúcar mais elevados na região Norte e Nordeste, demandou a existência de uma legislação rígida que impedisse a transferência de açúcar entre as regiões produtoras (já que os custos de produção mais baixos de São Paulo e demais estados produtores da região Sul) permitiam que o produto chegasse aos mercados nordestinos com preço competitivo mesmo quando se consideravam os custos de transportes entre as regiões. Esta política de preços foi a que vigorou até antes da liberação dos preços ocorrida em fevereiro de 1999.

\subsubsection{A década de 60: o incentivo às exportações e a grave crise de superprodução} da safra 1965/66

Diversos fatores conjunturais ocorridos na década de 60 alteram as perspectivas da agroindústria açucareira do Brasil, o que por sua vez influenciou a ação estatal, já que esta sempre se mostrou ser uma reação aos processos econômicos e sociais. A percepção do IAA (não obstante as intensas flutuações na oferta e nos preços mundiais no curtoprazo), eram de que os excedentes exportáveis do Nordeste não seriam suficientes para satisfazer as crescentes demandas interna e externa pelo produto. Desta forma, o Instituto novamente adotou uma política expansionista, visando incrementar as exportações e ampliar o parque industrial e a lavoura de cana.

Dentre os fatores conjunturais destacam-se a Revolução Cubana, que, ao estabelecer o regime socialista em 1959, excluiu Cuba do Mercado Preferencial (MP) norte-americano e abriu as portas para as exportações brasileiras (até então restritas ao Mercado Livre Mundial), permitindo o escoamento dos excedentes do açúcar do 
Nordeste, que ainda era dependente do mercado consumidor do Centro-Sul e dos mercados externos.

Na década de 60, durante o Governo Jânio Quadros, diversas medidas forma tomadas visando aumentar as exportações brasileiras de açúcar, que passaram a ser encaradas como fonte geradora de divisas. Em abril de 1961 foram editadas as normas para a centralização e coordenação das exportações de açúcar, além da criação de uma Divisão de Exportação no IAA.

A partir de então, deu-se um novo sentido ao planejamento do subsetor, procurando ajustar sua política ao planejamento sócio econômico de âmbito nacional. Em relação as decisões tomadas pelo IAA, estas passaram a considerar o caráter estratégico e dinâmico das exportações, priorizando a substituição do controle da produção açucareira pelo seu aumento substancial e programado, sendo dada atenção especial para vencer os problemas da área agrícola, que apresentava baixo índice de produtividade

Baseados em expectativas otimistas e na possibilidade de ofertar o açúcar no mercado preferencial norte-americano, foi lançado Plano de Expansão da Indústria Açucareira Nacional, que objetivava alcançar a meta de produção de 100 milhões de sacos em 1971. Desta forma, aumentam-se as cotas de produção das usinas do País para 100 milhões de sacos, sendo que São Paulo e Paraná receberam parcelas consideráveis das cotas adicionais, o que, somados às novas usinas, lhes conferiu deterem conjuntamente $40 \%$ da produção brasileira total.

Porém, em meados de 1964 os sintomas de uma nova crise de superprodução de açúcar do País começavam a aparecer. Nesta época, a deterioração dos preços no Mercado Livre Mundial (que tornavam gravosas as exportações brasileiras, mesmo considerando-se os lucros obtidos com a exportação para o Mercado Preferencial Americano), aliadas a um grande aumento da produção brasileira e às dificuldades no mercado interno, fizeram que os excedentes brasileiros de açúcar tornassem um problema de difícil equacionamento. 
A situação se agravou mais na safra de 1965/66, quando a produção excedeu em muito às previsões do Instituto, fazendo com que os estoques mais que duplicassem. Desta forma, nesta safra ocorreu uma das piores crises já enfrentadas pela agroindústria canavieira do País. O reflexo sobre os preços pagos aos produtores foi imediato, sendo que em setembro de 1966, na região Centro-Sul, a saca de açúcar era vendida por menos da metade do valor tabelado.

A análise dos fatores da crise de superprodução de 1965/66 apontam para as excelentes condições climáticas observadas nesta safra, para a incapacidade de intervenção do IAA dados os recursos e os instrumentos legais e administrativos disponíveis, e para o erro de avaliação das tendências do mercado internacional, que levou a um aumento exagerado da capacidade agrícola e industrial, principalmente na região Centro-Sul e particularmente em São Paulo, onde se verificou uma expansão de $22 \%$ da área de cana plantada.

\subsubsection{A lei № 4870 (dezembro de 65)e o pagamento da cana pelo Teor de Sacarose}

Devido aos graves conflitos surgidos entre fornecedores de cana e usinas, o Governo Federal intervém através da promulgação da Lei № 4870 , de dezembro de 1965, considerada por muitos como um marco para a evolução do setor. Algumas inovações introduzidas, principalmente relativas a produção, aos preços e ao fornecimento da cana foram bastante importantes, tendo algumas prevalecido até a safra $1997 / 98$.

Em relação às exportações, estabeleceu que a região Norte-Nordeste teria prioridade às exportações destinadas aos mercados preferenciais, ou seja, as exportações desta região conseguiriam os melhores preços vigentes no Mercado Preferencial norteamericano, que era uma forma de compensar o Nordeste pela perda definitiva dos mercados consumidores do Centro-Sul.

Quanto aos preços da cana-de-açúcar, instituiu uma grande inovação (que vigorou até a safra de 1997/98), que era vincular o pagamento da cana não mais ao preço 
do açúcar e do álcool e ao rendimento industrial das usinas (conforme regia o Estatuto da Lavoura Canavieira e a Resolução № 109/45), e sim ao teor de sacarose e pureza da cana do fornecedor.

Desta forma, o preço da cana seria calculado sobre um valor básico - estipulado a partir dos custos de produção agrícola, sendo que a Fundação Getúlio Vargas ${ }^{14}$ foi encarregada pelo IAA do levantamento dos mesmos nas principais regiões açucareiras do País - e a uma parcela correspondente ao rendimento industrial do fornecedor que estivesse acima do rendimento médio do Estado.

Com este mecanismo pretendia-se fornecer incentivos para que fosse produzida cana de melhor qualidade (forçando os empresários racionalizar sua produção e utilizar cana com mais alto teor de sacarose), e desvincular os preços da matéria-prima dos produtos finais, procurando evitar que o fornecimento da cana estivesse sujeito às oscilações dos preços do açúcar, o que ocasionava sua superprodução ou escassez.

Em relação aos preços do açúcar, conforme visto anteriormente, a partir da promulgação da Lei № 4870 passaram a ser fixados a partir dos custos médios de produção regionais, o que implicava em preços mais altos para a região Norte-Nordeste, cujos custos de produção eram maiores. De certa forma garantia-se a produção na região comparativamente menos eficiente, sendo que justamente os consumidores das regiões mais pobres pagavam um preço mais alto pelo produto.

Portanto, a partir de 1967, quando entrou em vigor a sistemática de preços imposta pela Lei № ${ }^{0} 870$, adotava-se um sistema de preços médios regionais (tanto para o açúcar como para a cana), sendo que na região Norte-Nordeste prevaleceriam preços mais altos, devido aos mais altos custos de produção.

Porém, embora houvesse uma legislação que objetivava impedir que o açúcar produzido na região Centro-Sul entrasse no mercado nordestino, este sistema acabou

\footnotetext{
${ }^{14}$ Conforme Gomes (1979, p138): "só há notícia de dois levantamentos de custos realizados, para o IAA, (pela Fundação Getúlio Vargas): um em 1965/66 e outro dez anos depois. Nesse ínterim, as informações de custo disponíveis pelo Instituto, na melhor das hipóteses, resultariam de correções de valores apurados, feito à base de indicadores de preços".
} 
permitindo que o açúcar produzido no Sul ganhasse espaço naquela região devido aos seus custos e preços mais baixos.

Desta forma, a partir de 1971, foi novamente alterada a forma de fixação de preços dos produtos, além de ser instituído um subsídio ${ }^{15}$ aos produtores do Nordeste, através da "equalização de preços". Novamente os preços voltavam a ser únicos em todo o território nacional (conforme o Decreto-Lei № 1186, de agosto de 1971), mas os produtores nordestinos teriam um subsídio anualmente decrescente, nas sete safras seguintes $^{16}$, para cobrir as diferenças entre os custos de produção das duas regiões produtoras.

A partir da aplicação dos artigos 5o da Lei №4870 (que permite que o IAA estabeleça cotas mensais de produção de açúcar) e do $51^{\circ}$ (que dispõe que os fornecedores de cana participarão da valorização dos estoques oriundos da fixação das cotas mensais de comercialização, decorrentes dos aumentos ou reajustes de preços dos produtos), o IAA estabeleceu, através das Resoluções №s 2.004 e 2.009/68, que os fornecedores, a partir da safra 1969/70, participariam também dos eventuais aumentos de preços verificados nos estoques de açúcar retidos para serem comercializados em cotas mensais.

\subsubsection{Decreto Lei № 1974 (agosto de 1966): a divisão do País em duas regióes produtoras}

Em agosto de 1966, foi emitido o Decreto-Lei № 1974/66, que dividia o País em duas regiões açucareiras: a Norte-Nordeste e a região Centro-Sul ${ }^{17}$, sendo que a transferência de açúcar entre estas duas regiões passava a depender de autorização prévia do IAA. Ramos (1991) salienta que procurava-se com isto proteger a produção de açúcar

\footnotetext{
15 Embora freqüentemente utilizado, o termo subsídio, a rigor, não está corretamente empregado. Tecnicamente este valor não é considerado subsídio pelo governo nem pela Organização do Comércio (OMC), já que não envolve diretamente recursos orçamentários ou de renúncia fiscal.

${ }^{16}$ Deve ser notado que o mesmo existe até hoje.

${ }_{17}$ Atualmente fazem parte das referidas regiōes os seguintes Estados: Norte-Nordeste: Alagoas, Bahia, Ceará, Maranhão, Pará, Paraiba, Pernambuco, Piauí, Rio Grande do Norte, Sergipe e Tocantins; CentroSul: Espírito Santo, Goiás, Mato Grosso, Mato Grosso do Sul, Minas Gerais, Paraná, Rio de Janeiro, Rio Grande do Sul, Santa Catarina e São Paulo.
} 
do Nordeste (já que o produto do Centro-Sul chegava ao Nordeste a um preço inferior), sendo que a sustentação da produção nordestina não se resumia mais à colocação do produto deste região na Centro-Sul, mas sim de proteger a produção nordestina em seu próprio território.

A partir de 1968, os preços praticados no Mercado Livre Mundial começaram a se recuperar, já que o consumo passou a superar a produção. Foi celebrado um novo Acordo Internacional do Açúcar (a vigorar a partir de janeiro de 1969), e o Brasil firmava uma posição de exportador mais sólida do que até então, devido aos menores excedentes mundiais do produto e à sua participação no Mercado Preferencial norteamericano.

Com o Governo Costa e Silva novos rumos foram traçados no que se refere à recuperação agroindústria canavieira depois da crise de 1965/66. Foram adotadas medidas de longo prazo, tais como a construção de terminais açucareiros de Recife e Maceió, e o estabelecimento de um convênio com o Banco de Desenvolvimento de Minas Gerais para o financiamento de projetos de racionalização do setor, preocupação que perdurou durante toda a década de 1970.

A partir de 1968, o fomento às exportações brasileiras como um todo foi uma das estratégias adotadas para o desenvolvimento do país. Neste contexto, insere-se o subsetor canavieiro, sendo neste período que as exportações de açúcar passaram a assumir um caráter permanente.

Para atender os objetivos da política nacional de aumentar as exportações, algumas questões do subsetor sucroalcooleiro concernentes à oferta do produto, tais como as dimensões e o aproveitamento da capacidade instalada, o grau de eficiência do sistema produtivo e a estrutura do sistema de comercialização, passaram a ser analisadas.

A primeira ação efetiva neste sentido foi a criação, em maio de 1969, no Estado de São Paulo, do Laboratório Agroindustrial de Piracicaba, e da Estação Experimental de Cana-de-Açúcar de Araras (na qual se desenvolveriam novas variedades de cana e se estudariam os métodos produtivos mais adequados). 
3.11.5 A década de 70: o fomento às exportações, os programas de melhoria de produtividade e de racionalização da produção, os choques do petróleo e o desenvolvimento do Proálcool

3.11.5.1 O fomento às exportações, os programas de melhoria de produtividade e de racionalização da produção

No início da década de 70 diversos programas objetivando melhorar os índices de produtividade agrícola e industrial foram lançados, com o objetivo de tornar a produção brasileira mais competitiva e incrementar as exportações.

Em relação ao aumento de produtividade agrícola, foi instituído o Programa Nacional de Melhoramento da Cana de Açúcar, criada uma nova entidade junto ao Instituto, o PLANALSUCAR, além de diversas estações agronômicas nos Estados de São Paulo, Rio de Janeiro, Alagoas e Pernambuco.

Juntamente com a implantação do PLANALSUCAR, outros programas desenvolvidos pelo IAA faziam parte da política de modernização tecnológica: o Programa de Racionalização da Agroindústria Canavieira, que procurava melhorar a produtividade e modernizar o parque agrícola e industrial, além da construção de terminais açucareiros.

Em maio de 1971 foi estabelecida a nova cota de produção nacional de 100 milhões de sacos, sendo alterado o conceito do limite global de produção, que passava a ser o somatório de dois contingentes regionais (das usinas situadas na região Norte/Nordeste e das localizadas na Centro-Sul), correspondentes à soma das cotas das usinas situadas em cada região produtora, o que permitia a expansão da produção de açúcar nos estados e nas usinas que dispusessem de melhores condições agroindustriais.

Também foram dados incentivos, em agosto de 1971, às fusões, incorporações e relocação das usinas em todo o País (dentro da mesma região geoeconômica), conforme o Decreto Lei $\mathrm{N}^{\mathrm{o}} 1186$. Tanto as usinas como os fornecedores que se fundissem dentro deste novo sistema receberiam benefícios e incentivos, o que, acabou estimulando a tendência à concentração industrial existente no setor. 
Ao tratar da evolução do processo de concentração, Ramos (1991) salienta que as alterações legais trazidas pelo Decreto-Lei № 1186, reforçaram uma tendência à concentração já observada desde o final da década de 50. Segundo Szmrecsány (1979), o que se pretendia era dar às usinas condições de aumentar a produtividade e reduzir seus custos de produção, que seria possível graças às economias de escala decorrentes das fusões, e às economias proporcionadas pela relocação das usinas em áreas com melhor infra-estrutura e mais apropriadas para a produção.

Em relação aos preços das duas regiões produtoras, o Decreto-Lei № 1186 igualava, conforme comentado anteriormente, os preços da cana e do açúcar nas regiões Norte-Nordeste e Centro-Sul, através de subsídios concedidos à região Norte-Nordeste provenientes do Fundo Especial de Exportação e de outros a serem consignados pelo Conselho Monetário Internacional.

A partir da criação do Programa Nacional de Melhoramento da Cana-de-Açúcar e do Programa de Racionalização da Agroindústria Açucareira, as exportações totalizaram mais de 1,2 milhões de toneladas métricas (proporcionando a terceira receita cambial das exportações brasileiras), o que correspondia a $6 \%$ de todo o açúcar comercializado no mercado internacional (Szmrecsány, 1979).

Entre outubro de 1971 e janeiro de 1972, a redução nos estoques mundiais fez com que os preços no mercado internacional aumentassem quase $100 \%$, beneficiando os países exportadores, em especial o Brasil, que passou a ser o primeiro produtor mundial de açúcar centrifugado de cana, o segundo exportador, e um dos únicos países a possuir capacidade instalada para a fabricação de mais de dois milhões de toneladas métricas anuais.

A alta dos preços internacionais, que perdurou entre 1971 e 1975, fez com que se revogassem as cotas de exportação para o Mercado Livre Mundial a partir de 1972, o que tornou possível para o Brasil usar seus excedentes acumulados em safras anteriores e utilizar sua capacidade produtiva ociosa. A figura 2 traz a evolução do setor açucareiro entre 1935-1982. 


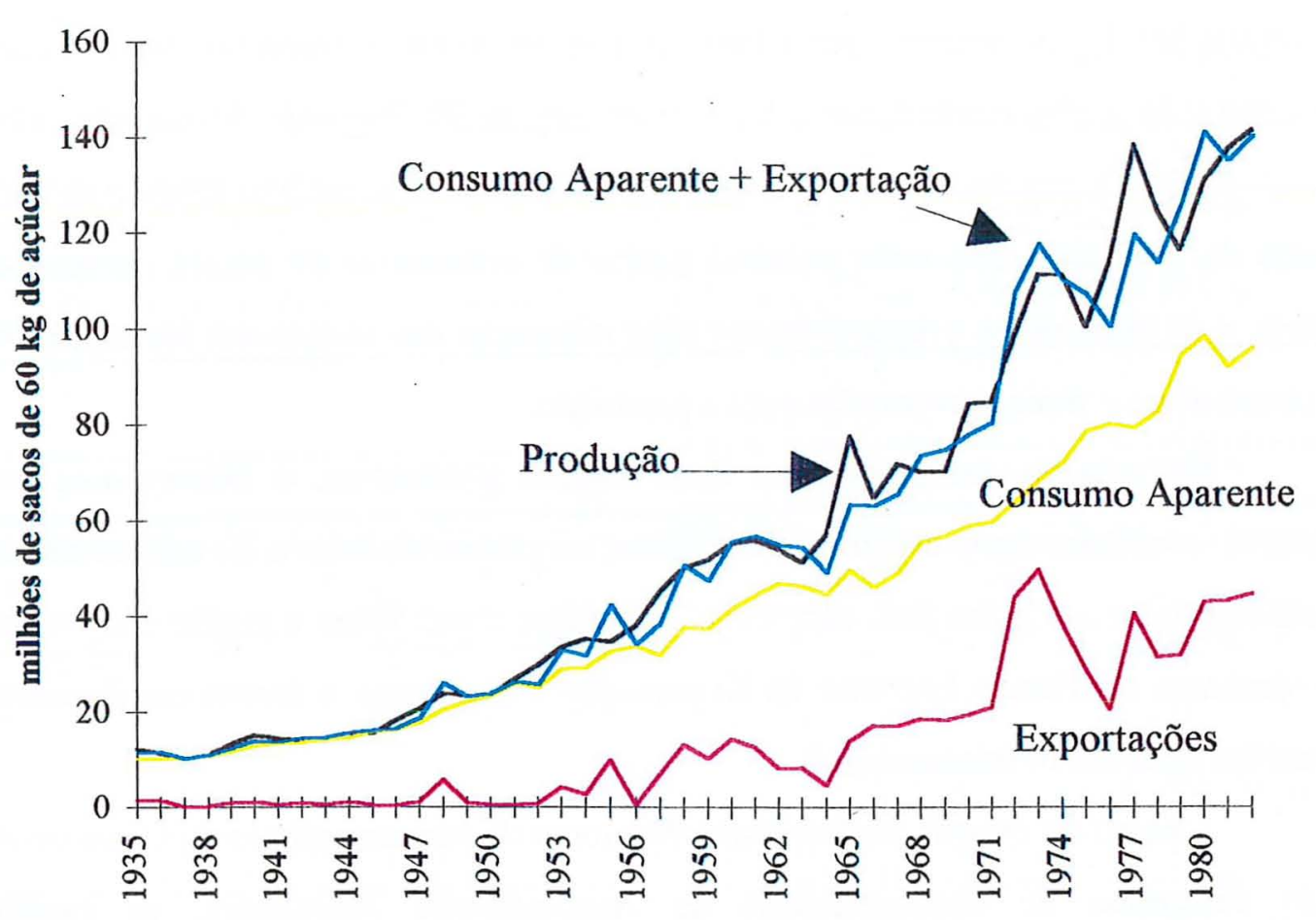

Figura 2 - A evolução do setor açucareiro: 1935-1982

Note pela Figura 2 (elaborada a partir de Santos, 1993, p. 287), que no ano de 1973 atingiu-se a máxima quantidade exportada, que começou a declinar a partir daí.

Conforme Szmrecsány (1979), entre 1969 e 1973 as exportações brasileiras cresceram $180 \%$. Em termos monetários, o valor global das exportações passou neste período de US\$112 milhões de dólares para US\$ 600 milhões de dólares, sendo que o valor médio da tonelada métrica, no período considerado, evoluiu de US\$105 para US\$202 dólares. Sendo o IAA o único exportador do açúcar brasileiro e como este pagava aos produtores um preço inferior ao conseguido com as exportações, o saldo do Fundo Especial de Exportação aumentou consideravelmente, permitindo ao Instituto ampliar sua política de modernização do setor, sendo os recursos destinados à modernização das usinas; aos subsídios de preços ao consumidor; às fusões, relocação e incorporação das usinas; e, ao reforço de capital de giro às cooperativas de produtores de 
açúcar. O financiamento para as empresas do complexo era feito em condições extremamente favoráveis pelo IAA ${ }^{18}$.

Mas esta política não era unanimemente aceita por usineiros e fornecedores, que reclamavam sobre a forma da distribuição de cotas e sobre os preços praticados. Alegavam uma defasagem dos preços do açúcar e da cana em relação aos insumos, pleiteando que os preços fixados considerasse a receita exportadora gerada pelo setor, melhorando a remuneração real dos produtores e evitando sua descapitalização. Nesta época, muitos fornecedores de cana abandonaram o plantio, mudando de atividade ou mesmo arrendaram ou venderam suas terras às usinas.

Em relação à política de preços do setor, Gomes (1979) salienta que embora desde 1975 a Fundação Getúlio Vargas viesse fazendo os levantamentos de custo de produção da agroindústria nas duas regiões açucareiras, parecia que os mesmos não eram utilizados para se estabelecer os preços dos produtos, e que as distorções existentes eram realmente no sentido de fixar os preços abaixo dos mesmos, o que sugere um paradoxo: como se explicar a expansão da agroindústria canavieira se os preços de seus produtos eram fixados abaixo dos custos de produção?

$\mathrm{O}$ autor explica que a remuneração real da agroindústria canavieira era suficiente para a sua expansão devido a diversos tipos de crédito e subsídios: "postergação de pagamentos, suspensão de retenções, subsídios de juros, amplos prazos de carência, inexistência de correção monetária, subsídios de preços..." (Gomes, 1979, p.140).

Desta forma, a característica da intervenção governamental era de operar a preço baixo, remunerando os produtores desigualmente devido às diferenças de produtividade, compensando as perdas de liquidez impostas pelo baixo preço com a política paternalista dos créditos subsidiados.

Embora os preços do açúcar no mercado internacional estivessem em patamares elevados até meados da década de 70 , era uma situação instável a médio prazo, sendo

\footnotetext{
${ }^{18}$ Conforme Ramos (1991, p.198): "Para o Norte e Nordeste, juros de 10\% ao ano; 3 anos de carência; 10 anos para pagar. No Centro-Sul, $12 \%$ ao ano; 3 anos de carência; 10 anos para pagar". Não era cobrada a correção monetária.
} 


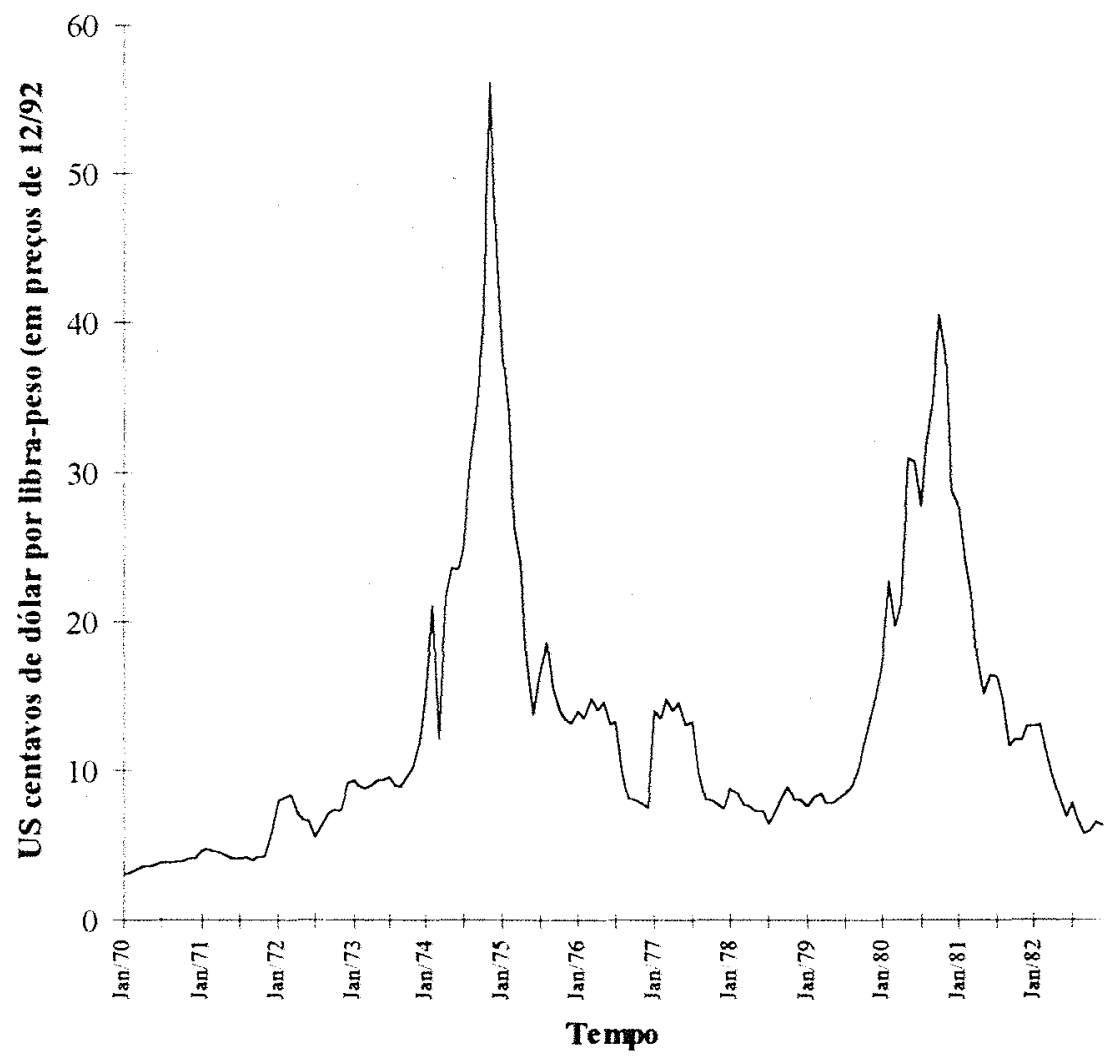

Figura 3 - Evolução dos preços mundiais de açúcar: 1970-1982 Fonte: elaborada a partir de Santos (1993, p. 285).

que as tendências poderiam se reverter, o que realmente aconteceu a partir de 1975. Do preço máximo alcançado em novembro de 1974 , as cotações do açúcar começaram a cair, sendo que entre dezembro deste ano e maio de 1975 o preço se reduziu a praticamente um quarto do valor praticado. A figura 3 traz a evolução dos preços do açúcar mundial, entre 1970-1982.

Note que ainda que os preços internacionais já viessem apresentando tendência de alta desde o início da década, em novembro de 1974 eles atingem seu máximo, começando a declinar significativamente a partir de maio de 1975.

Dos diversos fatores que contribuíram para a queda de preços, são destacados a queda de consumo dos países importadores, e as previsões de aumento de oferta mundial, sendo que seus efeitos não foram imediatos na economia brasileira devido aos 
contratos de fornecimento anteriormente firmados pelo IAA. Contudo, a partir de 1975, os recursos do Fundo Especial de Exportação começaram a se reduzir, enfraquecendo a força política do Instituto.

Por sua vez, nesta época, os altos preços do petróleo, decorrentes da política de preços dos países exportadores de petróleo (OPEP), e o endividamento externo crescente do Brasil passaram a ter importância fundamental na definição da política energética a ser adotada, fazendo ressurgir o interesse pela produção de álcool tanto por parte do governo (às voltas com problemas de balanço de pagamentos), como dos usineiros (que haviam ampliado suas usinas para venderem açúcar no mercado internacional e que se deparavam com preços externos do produto em declínio). Desta forma, a situação conjunta destes dois mercados - o do açúcar e do petróleo - acabou determinando a política nacional do álcool combustível.

\subsubsection{O $1^{\mathrm{0}}$ choque do petróleo e o desenvolvimento do Proálcool}

Nos anos 70 havia uma forte aceleração da economia mundial, decorrente da política expansionista americana de meados da década de 60 , e uma forte dependência mundial pelo petróleo importado dos países árabes. No fím de 1973 os países membros da OPEP elevaram abruptamente o preço do barril do petróleo, impactando significativamente todas as economias mundiais importadoras do produto.

A figura 4, elaborado a partir de Santos (1993, p. 279), traz a evolução dos preços do produto entre 1973-1982. 


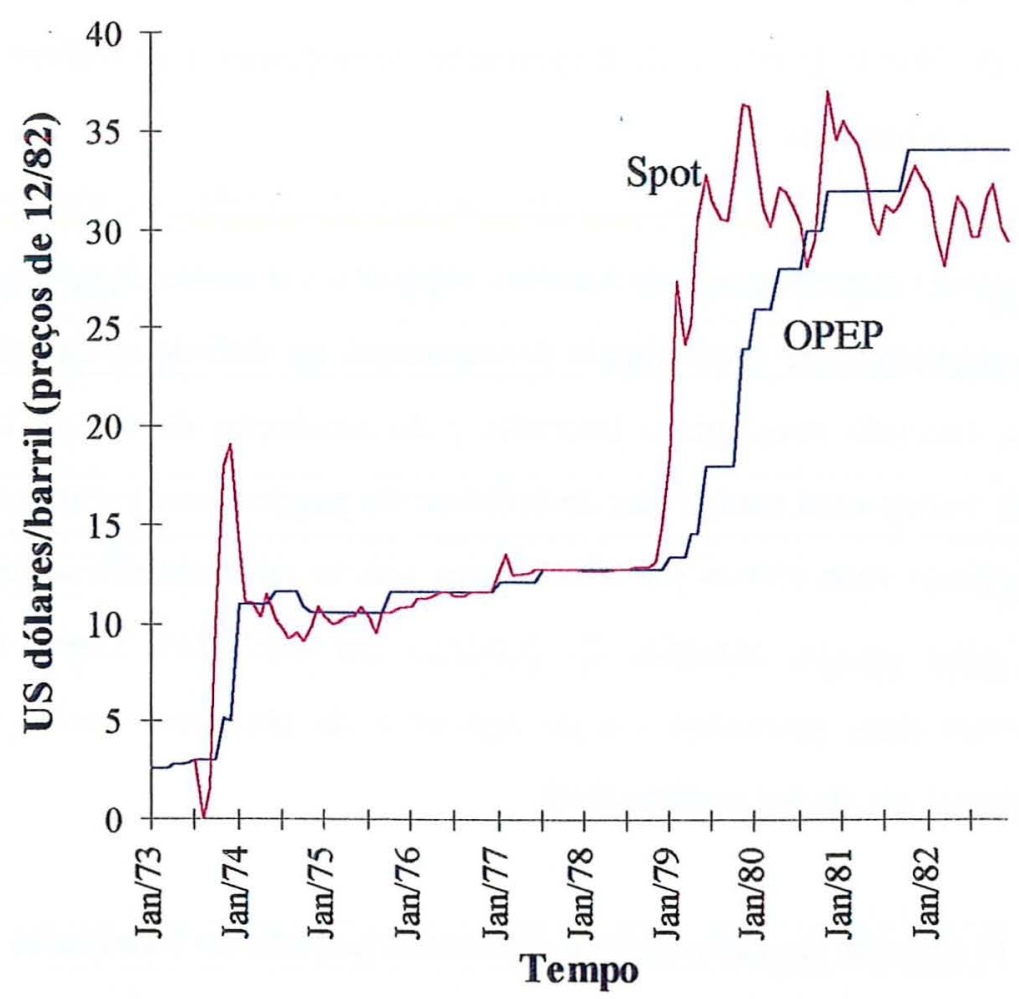

Figura 4 - Evolução dos preços do petróleo no mercado mundial.

Observa-se a grande alta ocorrida entre outubro de 1973 e janeiro de 1974 . O preço do barril do petróleo pago pela PETROBRAS aumentou 225\% entre 1973 e 1974.

Conforme Santos (1993), os efeitos sobre a balança comercial foram intensos: os pequenos déficits registrados em 1971 e 1972 (US\$530 milhões e US\$2.430 milhões de dólares respectivamente) e o superávit alcançado em 1973 (US\$2.179 milhões de dólares) se transformaram num déficit de US\$4,69 bilhões de dólares em 1974.

Em relação à inflação, a autora salienta que embora a alta de preços do petróleo não tenha sido a única responsável pelo salto ocorrido na taxa de inflação, ela certamente colaborou para o agravamento das tendências causadas pelos fatores estruturais da economia responsáveis pela mesma. A taxa de inflação (crescimento percentual do IGP) cresceu 122,6\% em um ano: entre 1973 e 1974 ela passou de 15,5\% ao ano para 34,5\%.

Neste cenário de tendências à inflação e problemas no balanço de pagamentos ocorreu a sucessão dos militares na presidência: em março de 1974 assumiu o general 
Ernesto Geisel em substituição ao general Emílio G. Médici. Desta forma, sob os efeitos do choque do petróleo, a questão que se colocava era como manter a taxa de crescimento do PIB (que era a opção feita pelo regime militar), e ao mesmo tempo conseguir o equilíbrio do balanço de pagamentos e conservar a taxa de inflação sob controle. Embora a política energética fosse considerada estratégica, de forma a reduzir a dependência do país em relação às fontes de energia externas, ela estava inserida dentro de um objetivo mais amplo que era o de manter o crescimento acelerado, tendo a inflação e o balanço de pagamentos sob controle.

Santos (1993) salienta que em 1974 o álcool combustível tinha lugar de pouco destaque na política energética, sendo que mesmo o uso da mistura carburante, com a adição do álcool anidro à gasolina, só iria ganhar importância no final de 1975. A ênfase em 1974 era dada, além do xisto, à energia nuclear, sendo que o Acordo Nuclear BrasilAlemanha havia sido negociado em 1974 e assinado em 12 de junho de 1975.

Embora tivesse sido autorizado no início da década de 70, pelo Conselho Nacional do Petróleo, o limite de $15 \%$ de adição de álcool à gasolina, este percentual nunca foi atingido devido a baixa produção de álcool anidro. Além disso, como a exportação de álcool era de livre iniciativa dos produtores, os mesmos ofertavam o produto nos mercados mais convenientes (doméstico ou exportação), fazendo com que a oferta no mercado doméstico fosse insuficiente.

Não obstante os efeitos da alta dos preços do petróleo no balanço de pagamentos e na taxa de inflação, poucas ações governamentais concretas foram tomadas em 1974, já que acreditava-se que os mecanismos de combate à inflação, o dinamismo das exportações e a entrada de recursos externos seriam suficientes para resolver os problemas que se apresentavam. Além disso, a descoberta de petróleo na bacia de Campos (RJ), no final de 1974, aumentaram o otimismo oficial, sendo inclusive cogitada a auto-suficiência do País em petróleo.

No final de 1975 o desequilíbrio macroeconômico tinha piorado bastante: a dívida externa continuava a crescer, as reservas cambiais se reduziam, as exportações comportavam-se aquém do previsto e a captação dos recursos externos não eram 
suficientes para cobrir os déficits das transações correntes. Em 9 de outubro de 1975 o presidente Geisel faz um discurso à Nação no qual anuncia uma série de medidas drásticas ${ }^{19}$ com o objetivo de reduzir ao máximo o déficit no balanço de pagamentos, sendo que entre elas é anunciado o Programa do Álcool.

Dentre as pessoas e entidades envolvidas na fase de formulação do Proálcool Santos (1993) cita tanto as de natureza pública (o presidente Ernesto Geisel, o Ministério da Indústria e Comércio (MIC), o Ministério das Minas e Energia (MME), a Secretaria de Planejamento (SEPLAN), o Ministério da Agricultura (MA), o Instituto do Açúcar e do Álcool (IAA), a PETROBRÁS, o Conselho Nacional do Petróleo (CNP), o Centro Técnico da Aeronáutica (CTA) e a Secretaria de Tecnologia Industrial (STI/MIC)), como as de natureza privada (a Cooperativa dos Produtores de Açúcar e Álcool do Estado de São Paulo (COPERSUCAR), o Sindicato da Indústria de Fabricação de Álcool no Estado de São Paulo, a Cooperativa Fluminense dos Produtores de Açúcar e Álcool (COPERFLU), o Sindicato da Refinação de Açúcar dos Estados do Rio de Janeiro e Espírito Santo, Associações de Produtores e Fornecedores de cana, e Associação Brasileira das Indústrias Químicas (ABIQUIM)), sendo que nesta fase a indústria automobilística teve atuação secundária.

Se por um lado os efeitos da alta dos preços do petróleo sobre o balanço de pagamentos eram bastante conhecidos, por outro a situação extremamente favorável da exportação do açúcar no ano de 1974 também impunha-se como questão relevante a ser considerada na política do álcool, sendo que a produção de açúcar para o mercado externo servia aos interesses tanto do governo (já que as divisas provenientes da exportação colaboravam para o equilíbrio do BP) quanto aos daqueles ligados ao setor açucareiro, que convergiam no sentido de que a política do álcool deveria ser feita de forma a não prejudicar as exportações de açúcar.

Para garantir o abastecimento de matéria-prima, abriram-se possibilidades de expansão da lavoura canavieira, e surgiram soluções de problemas básicos do setor, tais como o estabelecimento de preços mínimos para a cana-de-açúcar e para o açúcar.

\footnotetext{
${ }^{19}$ Encontradas em Santos (1993) p. 51.
} 
Mas, ao mesmo tempo que havia consenso quanto à necessidade de expansão da lavoura, surgiram pendências entre o IAA e a COPERSUCAR quanto à forma de fazế-la. Pelo IAA a expansão da lavoura deveria estar vinculada à produção de álcool em destilarias autônomas, a serem localizadas fora das áreas açucareiras tradicionais, para evitar que as usinas desviassem a cana destinada à produção de açúcar para a de álcool conforme sua conveniência, deixando de honrar os compromissos internacionais de exportação de açúcar (prejudicando o saldo do balanço de pagamentos), e reduzindo os saldos do Fundo Especial de Exportações ${ }^{20}$, comprometendo as receitas do próprio Instituto. Conforme Santos (1993), o IAA era apoiado pelo Ministério das Minas e Energia em relação à sua política de não perder as receitas advindas com as exportações de açúcar e de seus subprodutos.

Por sua vez, a COPERSUCAR argumentava que enquanto o álcool continuasse como subproduto do açúcar, não teria condições de se firmar como alternativa energética, sendo que suas sugestões para a ampliação da produção de álcool consistiam na utilização da capacidade ociosa das destilarias anexas já existentes, da modernização e ampliação das destilarias já instaladas, e da instalação de destilarias anexas às usinas que não as possuíam.

A capacidade ociosa das destilarias paulistas na safra 1974/75 (que era de 45\%) decorreu do aumento da capacidade instalada propiciada pelo projetos de modernização dos anos 70, e justificava a posição da COPERSUCAR de defesa do uso do álcool como carburante, e de que sua produção fosse feita primeiramente através da capacidade ociosa já instalada.

Santos (1993) salienta que o lobby dos produtores da agroindústria paulista de açúcar foi bastante ativo e visível, sendo que além do acesso aos altos círculos de decisão (inclusive prescindindo do canal institucional de comunicação, o IAA), a

\footnotetext{
${ }^{20}$ Que era constituído de taxas cobradas sobre cada saco de açúcar e cada litro de álcool não carburante produzido, e da receita líquida das exportações. Os produtores de açúcar recebiam pelo produto exportado um preço similar ao destinado ao mercado doméstico, ficando para o Fundo Especial de Exportações a diferença de preços entre os dois mercados, o que causava bastante insatisfação aos usineiros do CentroSul.
} 
COPERSUCAR divulgou diversos estudos técnicos sobre o assunto e usou intensamente a mídia e os fóruns públicos para defender seus propósitos.

Ao longo de 1974 diversos estudos e discussões surgiram sobre a quantidade de álcool anidro a ser misturado na mistura carburante, sobre o preço de paridade entre o açúcar e o álcool, e principalmente em relação a produção ser feitas nas destilarias anexas ou autônomas.

Em julho de 1975 foi promulgado o Decreto-Lei № 75.966, sendo estabelecido um preço de paridade para o álcool anidro de 44 litros de álcool por saco de $60 \mathrm{~kg}$ de açúcar cristal "standard" (que corresponde ao coeficiente de conversão do açúcar em álcool), ou seja, o álcool anidro seria adquirido pelo IAA ao preço equivalente de 44/60 avos do preço do quilo de açúcar cristal "standard". A produção deveria ser vendida à PETROBRÁS, sendo que ao Instituto caberia apenas a fiscalização da produção e da comercialização de todos os tipos de álcool e em todo o território nacional.

Também foi estabelecido no Decreto-Lei № 75.966 que a produção de álcool anidro deveria ser feita prioritariamente nas destilarias anexas às usinas (que teriam financiamentos concedidos pelas entidades oficiais de crédito, ou através do Fundo Especial de Exportação para se adequarem a produção de álcool) o que, segundo Szmrecsány $(1979$, p. 313) sinaliza que o objetivo principal do decreto era "garantir o nível de atividades da agroindústria canavieira do País, abrindo-lhe uma nova alternativa face a eventuais dificuldades no mercado mundial de açúcar". Como grande parte das usinas não possuía destilarias anexas, foram abertas linhas de crédito para que as usinas as instalassem ou as ampliassem, e também para que se instalassem destilarias autônomas.

As condições de financiamento estipuladas pelo Decreto eram as seguintes: no início financiava-se até $100 \%$ dos investimentos industriais (destilarias anexas ou autônomas), com juros de $15 \%$ ao ano para os projetos do Norte-Nordeste e de $17 \%$ nas demais regiões do País e prazo máximo de 12 anos, com carência de até 3 anos; cana-deaçúcar e outras matérias-primas: juros de 7\% ao ano, prazo máximo 5 anos, inclusive carência de até 2 anos, não havendo correção monetária em nenhum dos casos. 
A partir de 1977 , o financiamento ficava entre $70 \%$ e $90 \%$ dos investimentos industriais, dependendo do tipo de destilaria, da matéria-prima utilizada, e passou-se a exigir correção monetária de $40 \%$ da variação das ORTN's; os juros foram reduzidos para $6 \%$ para as destilarias anexas (4\% para a região da SUDAM/SUDENE) e 5\% para as destilarias autônomas (3\% para as áreas da SUDAM/SUDENE).

Os prazos de carência iniciais eram de três anos, sendo que a partir de 1982 ficou estipulada a carência de 3 anos para as destilarias anexas e de 4 anos para as autônomas. Neste mesmo ano, os encargos financeiros dos empréstimos passaram a uma taxa de juros fixa de $5 \%$ ao ano, acrescida de correção monetária, que era calculada da seguinte forma: nas áreas da SUDAM e SUDENE, até 60\% para as destilarias anexas e até $55 \%$ para as autônomas; nas demais regiões, até $70 \%$ para as anexas e até $65 \%$ para as autônomas. Além disso, a soma da correção monetária e dos juros não poderia exceder $55 \%$

Santos (1993) salienta a liderança do MIC nesta fase de gestação da política do álcool. Destaca também a importância primordial que deve ser creditada à atuação do Presidente Geisel na promulgação deste decreto, já que os parâmetros de decisão nesta época ainda eram desfavoráveis ao desenvolvimento do álcool combustível, dado que o mercado internacional do açúcar mostrava-se ainda favorável ao produto brasileiro (as receitas advindas de sua exportação superavam os gastos que o País deixaria de ter se não importasse o petróleo).

O discurso de Geisel feito à Nação em 9 de outubro de 1975, além de formalizar a idéia do Programa Nacional do Álcool, fixava a proporção da mistura da gasolina em $20 \%$, indicava que a cana-de-açúcar seria usada como matéria-prima industrial, e previa estímulos financeiros à expansão da lavoura canavieira, à montagem de destilarias anexas e autônomas, além de anunciar estímulos a programas que estimulassem a produção de álcool de outras fontes (batata-doce e mandioca).

O conflito existente pelo controle do Proálcool continuava acirrado. Para o IAA, que se encontrava com os saldos do Fundo Especial de Exportação reduzidos, era 
fundamental o controle do programa também pela fonte de recursos a ser criada ${ }^{21}$; por sua vez, o MIC previa um fundo especial para o financiamento da produção de álcool e para o subsídio ao preço de venda do produto quando este se destinasse à mistura combustível ou para a indústria química.

Pela minuta do anteprojeto que criava o Programa Nacional do Álcool, o IAA saía bastante fortalecido, cabendo ao Instituto o controle do PNA, no que dizia respeito ao fomento da produção de álcool, à modernização e ampliação das destilarias existentes e à instalação das novas, que deveriam se inscrever no IAA. Também ficava o Instituto com o monopólio da comercialização do álcool de todos os tipos e do mel residual, tanto no mercado interno como no externo, sendo que os recursos do Programa viriam da diferença de preço pago aos produtores e do preço de revenda.

A reação dos produtores de açúcar e álcool (através da COPERSUCAR, da COPERFLU, do Sindicato da Indústria da fabricação de Álcool, do apoio dos editoriais de jornais aos produtores e plantadores do Centro-Sul) foi no sentido de impedir a estatização da agroindústria canavieira. Embora os produtores admitissem o monopólio do IAA na comercialização do álcool anidro (tal qual já ocorria desde a criação do Instituto) não admitiam que a comercialização do álcool industrial também fosse exclusiva do IAA. Travou-se uma disputa de forças entre a COPERSUCAR e o MIC, que mostrava-se a favor da presença do Estado na economia, sendo que o lobby feito pela COPERSUCAR causou reações na burocracia federal, que declarou que o governo não se deixaria influenciar por pressões externas.

Conforme Santos (1993), o intenso lobby da COPERSUCAR contra o monopólio da comercialização do álcool aumentou o conflito das agências burocráticas pelo controle do PNA: a competição entre o IAA e a PETROBRÁS, no tocante à comercialização do álcool, tornou-se bastante intensa, sendo que o IAA tinha o apoio do Ministério da Indústria e do Comércio, e a PETROBRÁS, do Ministério das Minas e

\footnotetext{
${ }^{21}$ Que seria a diferença entre o preço pago pelo álcool aos produtores (paritário ao açúcar) e o preço recebido pela venda às distribuidoras de gasolina (paritário com a gasolina).
} 
Energia. Muitas reuniões foram necessárias, e diversos adiamentos ocorreram, sendo que as partes mostravam-se irredutíveis em seus pontos de vista.

Finalmente, em 14 de novembro de 1975, o Presidente Ernesto Geisel promulgou o Decreto-Lei № 76.593, que criou o Programa Nacional do Álcool, sendo que a Coordenação ficou a cargo de uma Comissão Interministerial Permanente, composta por representantes dos Ministérios da Fazenda, Agricultura, Indústria e Comércio, Minas e Energia, Interior e Secretaria de Planejamento, e era presidida pelo Secretário-Geral do MIC, saindo o IAA extremamente enfraquecido, já que suprimiu-se o monopólio de comercialização de álcool pelo Instituto.

Ao IAA coube a responsabilidade de receber as propostas de financiamento para modernização, ampliação ou instalação de destilarias e encaminhar o parecer técnico à Comissão Nacional do Álcool; estabelecer os preços de paridade para o álcool, exceto para o álcool carburante e para o álcool usado para fins industriais, estabelecer os preços do mel residual; estabelecer as especificações técnicas para o mel residual e para o álcool de qualquer origem; e, receber as inscrições das destilarias de álcool.

O CNP, por sua vez, ficou responsável por garantir o preço de paridade para o álcool combustível e para o destinado à indústria química, e pela coordenação de um programa de distribuição do álcool anidro entre as empresas distribuidoras de petróleo, que receberiam o produto a um preço por ele estipulado.

Embora fosse esta a situação resultante do Decreto № 76.593 , tanto o IAA como a PETROBRÁS continuaram pressionando em busca de seus interesses, conseguindo posteriormente obter papéis importantes na estrutura burocrática do Proálcool.

Em relação ao processo de implementação do programa, devem ser destacadas duas fases: a primeira inicia-se com a promulgação do Decreto-Lei № 76.593 , de novembro de 1975, e vai até 1978, correspondendo ao uso da mistura álcool-gasolina, à implantação das destilarias anexas, e ao envolvimento da indústria automotiva para a produção de carros a álcool; a segunda fase, iniciada em 1979, é a da produção em larga 
escala do álcool hidratado, para ser usado em carros movidos exclusivamente com este combustível.

Na primeira fase do programa, com a proporção de $20 \%$ de álcool na mistura carburante, seria necessário a expansão da produção de álcool para 3 bilhões de litros. Conforme Santos (1993), embora este objetivo tenha sido alcançado em 1977, três anos antes do previsto, a adição do álcool na proporção de $20 \%$ só foi conseguida em todo o território nacional em 1983.

Não obstante o objetivo primordial do Proálcool tivesse sido a substituição de parte da gasolina importada pelo combustível nacional, a partir de 1975 o mercado do petróleo apresentava-se estável, apesar dos seus preços encontrarem-se em um patamar mais elevado.

Apesar do modesto decréscimo das taxas de expansão do consumo deste combustível no Brasil, o cenário internacional relativamente estável parecia indicar ao governo que a questão era mais de ajustar a economia aos efeitos dos preços mais altos via controle da inflação, que atingia a barreira dos $40 \%$ anuais, e melhoria do balanço de pagamentos - do que alterar a estrutura energética do País, o que impôs um ritmo mais lento ao Proálcool. Embora o discurso do Presidente Geisel e dos Ministros da área econômica fossem no sentido de reduzir a participação do petróleo no consumo de energia do País, as mudanças efetivas relativas à matriz energética do País só iriam acontecer depois do segundo choque do petróleo, em 1979.

As explicações para o crescimento rápido da produção de álcool, contrastando com a lentidão das medidas oficiais, advém dos preços declinantes do mercado internacional de açúcar. Embora em 1976, a despeito dos preços vigentes, o presidente do IAA não visse motivos para a contração da produção açucareira, o programa do álcool mostrou-se como importante válvula de segurança do setor. Desta forma, a produção alternativa de álcool foi, conforme Ramos (1991), a "tábua de salvação" para os usineiros que haviam ampliado suas unidades produtivas para atender as exportações de açúcar, baseado numa expectativa equivocada de demanda mundial crescente. 
Segundo Santos (1993) mesmo que o ano de 1977 tivesse terminado com altos excedentes de açúcar (correspondentes a 12,2\% da produção), o IAA não contingenciou a produção, pois acreditava que quanto maior a capacidade de produção brasileira, maior seria seu poder sobre o mercado internacional de açúcar. Além disso, o Programa Nacional do Álcool já aparecia como solução para uma possível crise de superprodução açucareira.

Com efeito, na safra de 1977/78 o governo atendeu a solicitação do IAA de transformar 15 milhões de sacos de açúcar em álcool direto. Na safra seguinte, o IAA adotou o contingenciamento da produção (a demanda e os preços internacionais do Mercado Livre Mundial continuavam retraídos), reduzindo a produção autorizada em 15 milhões de sacas. Além disso, dos 120 milhões de sacos autorizados, estimava-se a transformação em álcool direto do equivalente em cana a 35 milhões de sacos de açúcar A figura 5 (elaborada a partir de Santos, 1993) traz a evolução da produção de álcool no Brasil entre 1930-1982.

Nota-se pela figura 5 que a produção total de álcool na safra 1975/76 foi da ordem de 550 milhões de litros; na safra de 1976/77 ela já atingiu 664 milhões de litros, sendo que na safra seguinte ela salta para aproximadamente 1.407 milhões, incluindo tanto o álcool direto como o subproduto do açúcar. 


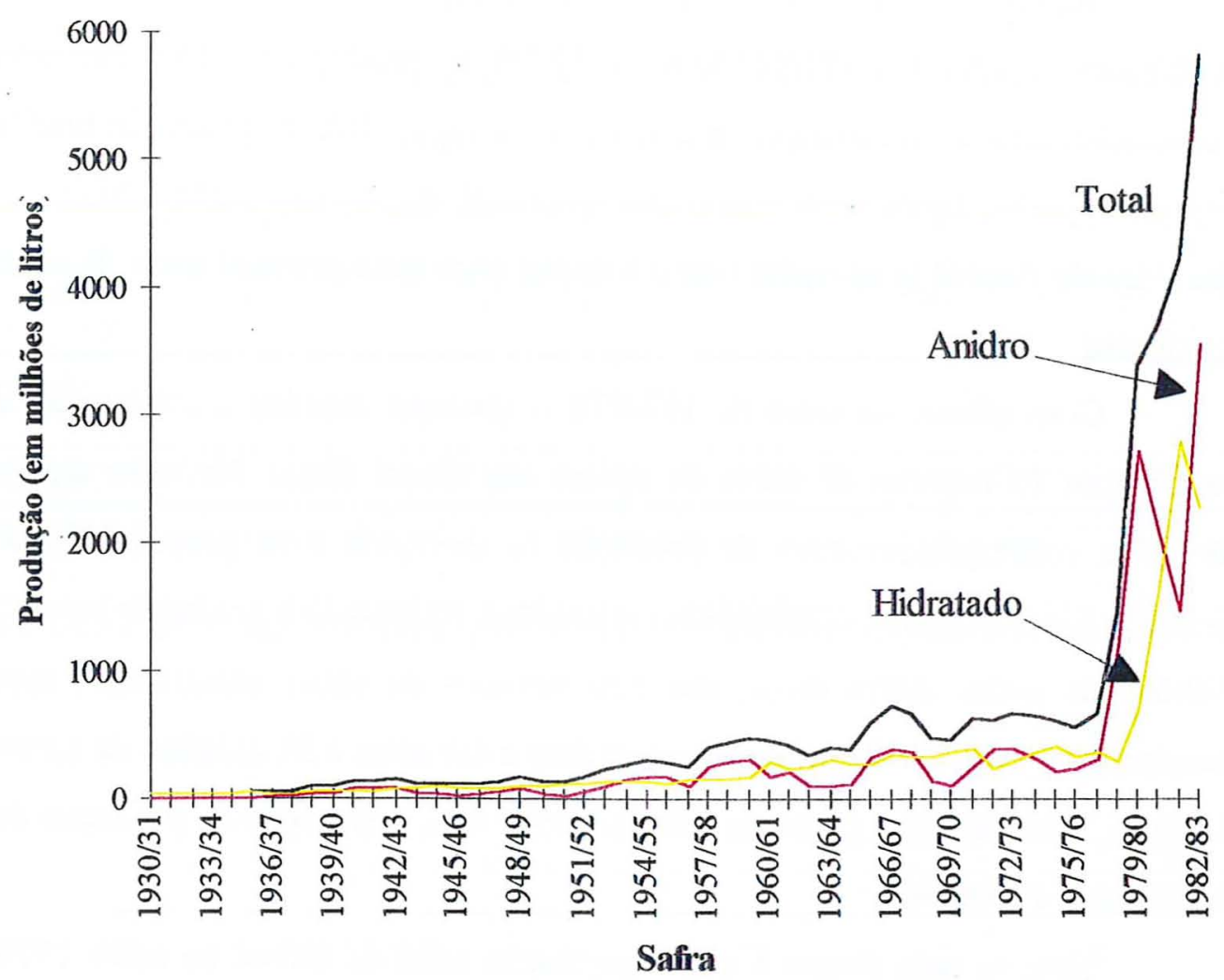

Figura 5 - Evolução da produção brasileira de álcool anidro, hidratado e total. Safras 1930/31-1981/82 (em milhões de litros).

Em relação ao envolvimento da indústria de equipamentos para destilarias e usinas e das montadoras de veículos, Santos (1993) cita que enquanto as primeiras aderiram prontamente ao programa, declarando-se estarem aptas já em 1976 para atender a demanda por seus produtos, as principais montadoras (Volkswagen, General Motors, Volvo, Mercedez-Benz, Ford e a Fiat, que havia começado operar no País há pouco tempo) e a Associação Nacional dos Fabricantes de Veículos Automotores (ANFAVEA) mostravam-se cautelosos em relação à viabilidade do Programa, parecendo desconfiar do comprometimento do Governo.

Quanto aos recursos para a execução do Programa, Santos (1993) salienta que na Primeira fase do Proálcool, os mesmos originavam-se de dotações orçamentárias da União (aprovadas anualmente) e dos saldos positivos da comercialização do álcool 
anidro misturado à gasolina. Em março de 1976, através da Resolução № 304/76, o Banco Central divulgou a regulamentação das operações industriais do Proálcool, estabelecendo que os recursos para o financiamento das instalação, modernização, ampliação das destilarias de álcool seriam provenientes da comercialização do álcool carburante, de provisões feitas pelo $\mathrm{CMN}$ e dos retornos e rendimentos líquidos de operações já realizadas, desde que os projetos tivessem sido anteriormente aprovados pela CNAL.

As operações de crédito rural foram regulamentadas pelo Banco Central, em junho de 1976, cabendo salientar que inicialmente o valor financiado correspondia a $100 \%$ dos valores orçados, com juros de $7 \%$ ao ano, e os prazos de pagamento variavam entre 2 safras e 12 anos, conforme o tipo de atividade.

Portanto, a regulamentação do Programa Nacional do Álcool era de responsabilidade de diversas instituições: o Conselho Nacional do Petróleo (CNP) regulava a comercialização e distribuição do álcool; a Comissão Nacional do Álcool (CNAL) era responsável pela normatização dos aspectos técnicos e econômicos; o Conselho Monetário Nacional e o Banco Central encarregavam-se dos aspectos financeiros, sendo que eles formavam um conjunto nem sempre em harmonia.

Dada a complexidade da estrutura de decisão montada para a execução do Proálcool, os empresários interessados na montagem de destilarias ou ampliação e modernização das já existentes queixavam-se da lentidão do processo existente ${ }^{22}$.

Desta forma, os atrasos na liberação dos mesmos fazia com que os empresários do setor reclamassem de prejuízos decorrentes de contratação de matéria-prima, bem como os produtores de usinas e destilarias, que ficavam com as destilarias prontas, aguardando a liberação de financiamento do Banco do Brasil. Mesmo a interferência

\footnotetext{
${ }^{22}$ Conforme Santos (1993), o processo de tramitação obedecia a seguinte sequiência: a pessoa interessada enviava a CNAL o projeto, o qual, conjuntamente com o IAA, avalia sua localização, seu enquadramento nos objetivos do PNA e a parte técnica. Estando aprovado pelo CNAL, a parte interessada tinha 90 dias para apresentar o projeto definitivo ao agente financeiro (geralmente o Banco do Brasil), que avaliava os aspectos bancários e econômico financeiros, visando aferir a capacidade do interessado em retornar o investimento. Após a aprovação pelo agente financeiro, uma súmula da operação era enviada ao Banco Central, ainda sujeita a aprovação desta entidade. Uma vez aprovado pelo Banco Central, era feito um reembolso ao agente financeiro contratado, que repassava o financiamento aos clientes.
} 
direta do presidente Geisel não diminuiu a lentidão do processo, sendo que a tramitação dos projetos de destilaria (do momento em que era enviado ao CNAL até a assinatura do contrato com o Agente Financeiro) demorava, nesta época, de sete a doze meses.

Portanto, a grande fragmentação do processo decisório da política e as contradições entre as diversas agências é considerada por Santos (1993) como a principal causa no atraso da implantação da mistura álcool-gasolina.

Para a safra de $1977 / 78$ foram tomadas outras medidas para reduzir os efeitos da crise de superprodução do açúcar além da conversão em álcool direto da cana, no sentido de estimular a produção de álcool. Dentre elas destacam-se o financiamento para os custos de comercialização (warrantagem), especialmente os de estocagem (a safra é feita ao longo de 6 meses e a comercialização durante o ano todo), sendo que para o açúcar este financiamento era de $60 \%$ do valor total produzido, e do álcool de até $80 \%$. Também foi concedido um suporte financeiro ao preço do álcool, para torná-lo uniforme em todo o território nacional, viabilizando sua produção (compensando os custos de transporte daquelas destilarias localizadas distantes dos centros de consumo).

Em relação ao preço do álcool combustível, que era um estímulo essencial para que os produtores aderissem ao Programa, não era considerado compensador, sendo objeto de constantes reivindicações: enquanto a COPERSUCAR reivindicava a relação de 37,5 litros de álcool por saco de $60 \mathrm{~kg}$ da açúcar (baseada nos custos de produção de cada produto), o Decreto $^{\mathrm{o}} 75.966$, de julho de 1975 , fixava a relação em 44 litros por saca de $60 \mathrm{~kg}$.

Esta relação foi alterada diversas vezes por Portarias do MIC, sendo finalmente fixada em 38 litros por saca de $60 \mathrm{~kg}$ de açúcar, o que, segundo Santos (1993), na ocasião era bastante satisfatória, principalmente para os produtores da região Centro-Sul.

O problema da estocagem do álcool era o mais grave enfrentado pelo PNA ao encerrar a primeira fase do Programa. Embora até então a PETROBRÁS tivesse se mostrado contrária ao programa (tendo inclusive questionado a viabilidade econômica do PNA em agosto de 1978 e ter declarado na mesma ocasião que a empresa não tinha qualquer responsabilidade sobre o mesmo, já que não havia sido incluída no Programa) 
ela seria responsável nos anos seguintes pelo controle da distribuição e tancagem do produto.

A falta de infra-estrutura para o escoamento do álcool ficou evidente com os grandes estoques de anidro produzidos sob os estímulos do PNA. Em Pernambuco e Alagoas cerca de 65\% do álcool anidro produzido na safra de 1977/78 estavam sem escoamento e sem locais para estocagem. Nem os usineiros, nem o IAA, nem a CNP se julgavam responsáveis pela distribuição e comercialização do produto, sendo que a PETROBRÁS e as Companhias Distribuidoras de Derivados de Petróleo, com o apoio do MME e do MIC, passaram a disputar o controle do sistema de distribuição do álcool.

Através da Resolução № 18/78, de novembro de 1978, atribuiu-se às Distribuidoras a responsabilidade de adquirir o álcool diretamente das usinas (segundo cotas mensais fixadas pelo CNP) e transportá-lo para os centros de mistura. A participação da PETROBRÁS neste processo seria somente através de sua Distribuidora, sendo que o IAA perdia mais uma de suas atribuições.

Desta forma, a segunda fase do Programa (caracterizada pelos carros movidos exclusivamente a álcool), iniciou-se com alguns problemas oriundos da primeira fase, dentre os quais destacam-se: o longo tempo para a aprovação dos processos dos projetos das destilarias; a ausência de correção monetária dos financiamentos concedidos às destilarias; a distribuição e armazenagem de álcool; o preço do álcool pago aos produtores; os recursos para financiamento da expansão da lavoura e da capacidade industrial; a estrutura decisória fragmentada; e, o desenvolvimento da tecnologia de motores movidos exclusivamente á álcool. Além destes, outra dificuldade enfrentada foi conseguir o envolvimento da indústria automobilística com o Proálcool (Santos, 1993).

\subsubsection{O $2^{\mathrm{o}}$ choque do petróleo e a retomada do Proálcool}

A retomada do Proálcool iniciou-se a partir do segundo choque do petróleo, ocorrido durante a primeira metade de 1979. Ao período de relativa estabilidade no mercado de petróleo (entre os anos de 1976 e 1978), seguiu-se outro no qual os países membros da OPEP - principalmente a Arábia Saudita, Irã e Iraque - disputavam o 
controle do mercado deste produto, divergindo sobre os preços e os volumes a serem exportados.

Enquanto alguns países optavam em expandir a produção, outros reduziram-na, mas os efeitos sobre os preços foram bastante intensos: ao longo de 1979 ocorreram diversos aumentos, sendo que no mercado spot de Rotterdam o produto era cotado, no final de 1979, em US\$36,80 dólares o barril e o preço fixado pela OPEP neste período era de US\$24,00 dólares (contra US\$12,58 dólares e US\$12,70 dólares, respectivamente, no fim de 1978 - conforme a figura 4).

Desta forma, os aumentos sucessivos dos preços do produto ocorridos no mercado internacional em 1979 aconteceram juntamente com a crise Irã-Iraque (com conseqüente redução de fornecimento do produto pelo Irã), retornando o problema de abastecimento do produto. Ficava evidenciado que, apesar de já ter passado pela outra crise anterior, a matriz energética do País pouco tinha se alterado, e o mesmo continuava vulnerável do ponto de vista energético.

A transição do governo Geisel para o de Figueiredo ocorreu, portanto, com o novo governo tendo que enfrentar os efeitos da segunda crise do petróleo, que eram mais devastadores que os da primeira, já que, embora durante o primeiro choque a magnitude do aumento tenha sido maior, no segundo choque o preço do barril de petróleo já se encontrava em US\$12,70 dólares em dezembro de 1978, e os aumentos ocorridos a partir deste nível de preços trouxeram impactos muito intensos na balança comercial brasileira. Entre 1978 e 1979 o valor das importações brasileiras cresceram 32\%, principalmente devido ao petróleo, quase triplicando o déficit na balança comercial (nesta época, a dependência energética brasileira em relação ao petróleo ainda era de 41,6\%; em 1973 era de $43,6 \%$ ).

Desta forma, não obstante os empréstimos externos disponíveis em abundância, o balanço de pagamentos fechou com um déficit de US $\$ 3,2$ milhões de dólares, sendo que em 1978 tinha ocorrido um superávit de US\$4,3 milhões de dólares; a dívida externa líquida cresceu $27 \%$ (passando de US $\$ 31,6$ bilhões de dólares para US $\$ 40,2$ bilhões de 
dólares); e, a inflação que em 1978 já havia passado a barreira dos 40\%, saltou em 1979 para $77 \%$ (Santos, 1993).

A resolução da questão energética, juntamente com o combate à inflação, passaram a ser questões prioritárias nesta fase. A política de substituição de derivados de petróleo por outras fontes de energia alternativas foi um importante instrumento utilizado pelo governo para reduzir o consumo de petróleo, e devido a ela o Programa Nacional do Álcool tomou impulso, já que foi acelerada a implantação da segunda fase do Programa.

Em junho de 1979, durante uma reunião do Conselho de Desenvolvimento Econômico, presidida pelo Presidente da República, estabeleceu-se a nova meta de produção de álcool, de 10,7 bilhões de litros, a ser atingida em 1985.

Quanto aos recursos necessários, o CDE decidiu investir US\$5 bilhões de dólares no Programa durante o governo Figueiredo (embora não houvesse acordo quanto ao modo de conseguir estes recursos) que destinavam-se à expansão da área de cana plantada e das capacidades das destilarias de álcool, ao programa de desenvolvimento tecnológico para melhorar a matéria-prima, ao desenvolvimento da tecnologia envolvida no processo produtivo, e à expansão do sistema de tancagem, um dos gargalos do Programa.

A partir da crise $2^{\underline{a}}$ do petróleo, procurou-se reformular não só o Proálcool, mas toda a política energética brasileira. Em julho de 1979 foi criada a Comissão Nacional de Energia (CNE), e em dezembro de 1981 foi criada a Comissão SEPLAN de Energia (CSE), que juntamente com a CNE, deveria administrar e distribuir os recursos do programa. As decisões relativas às questões energéticas ficariam concentrados no SEPLAN, através de sua Comissão de Energia (CSE).

Em relação à política do álcool, o governo procurou centralizar suas decisões, já que sua estrutura decisória muito fragmentada dificultava a implantação do programa. A retomada do Programa trouxe, conforme Santos (1993), novamente à tona a questão da disputa pelo seu poder, tendo inclusive o Ministro da Indústria e do Comércio (MIC) e o 
Ministro das Minas e Energia (MME) debatido publicamente sobre a questão, até que o Presidente Figueiredo estabeleceu que o controle sobre o Programa caberia ao MIC.

Em meados de 1979 o Presidente Figueiredo decidiu separar a formulação e a execução da política do álcool. Através do Decreto-Lei № 83.700 (de julho de 1979), ele substituiu a Comissão Nacional do Álcool (CNAL) pelo Conselho Nacional do Álcool (CNAL), que ficou encarregado de formular a política e fixar as diretrizes do Proálcool, e pela Comissão Executiva Nacional do Álcool (CENAL), que era responsável, dentre outras coisas, pela execução das decisões do Conselho Nacional do Álcool.

Neste novo arranjo institucional o Presidente do IAA tomava parte da CENAL, atribuindo-se ao Instituto um importante papel no processo de tomada de decisão. Desta forma, esperava-se agilizar os trâmites dos processos de instalação das destilarias, alvo freqüente de queixas da iniciativa privada. Foram definidas também as instituições de financiamento envolvidas no programa, cabendo ao Conselho Monetário Nacional definir as fontes dos recursos a serem utilizadas e as condições dos financiamentos.

Segundo Santos (1993), para a análise dos projetos das destilarias foi instituído um roteiro "único" para a submissão dos projetos, sendo que a partir de então praticamente acabaram as reclamações sobre a lentidão do processo, sendo que as queixas oriundas em 1980 referiam-se ao atraso da liberação dos recursos financeiros, causado pelo agravamento da crise econômica enfrentada pelo País.

Em relação a orientação dada aos empresários pela CENAL, Ramos (1991) salienta que era no sentido dos projetos apresentarem integração entre a atividade agrícola e industrial, para garantir o fornecimento de matéria-prima. No caso da cana ser de fornecedores, os projetos deveriam prever fornecimento durante a vida útil dos equipamentos industriais. No caso das destilarias anexas, os financiamentos poderiam ser feitos desde que o incremento da produção visasse a produção de álcool direto e desde que fosse comprovada a potencialidade da expansão da área agrícola, o que potencializava o crescimento da lavoura canavieira.

Desta forma, Ramos (1991) salienta que a estrutura do complexo de produção integrada foi mantida e reforçada pelo Proálcool, sendo que a propriedade fundiária é 
que permitia o acesso ao financiamento Estatal e a instalação de destilarias. A expansão da produção alcooleira para outros estados foi feita nos mesmos moldes de estrutura produtiva integrada, a partir da posse da estrutura fundiária.

Em relação ao envolvimento da indústria automobilística nesta segunda fase do Programa, ela requeria uma garantia do Governo sobre o seu próprio comprometimento e sobre a criação de uma infra-estrutura para a distribuição do álcool hidratado, já que a questão do sistema de tancagem e distribuição do álcool era uma questão essencial para o sucesso do Programa.

Pela Resolução № 18/78, as distribuidoras tinham sido encarregadas de comprar o álcool nas usinas e destilarias e transportá-lo até os centros de mistura, mas nesta nova fase, dada a nova escala de produção, este sistema não se mostrava mais compatível. Conforme Santos (1993), era necessário a construção de uma rede de tanques de armazenagem e centros de coleta, além de um sistema de transporte (dutos, ferrovias, rodovias, cabotagem) para transportar o álcool das usinas e destilarias para os centros de coleta e destes para os centros de mistura.

A PETROBRÁS e as Distribuidoras (em sua maioria empresas multinacionais) travaram acirrada disputa pelo controle do novo sistema de tancagem e distribuição. A autora analisa as ações da PETROBRÁS no sentido de deter o controle total (tanto da distribuição como da produção) sobre o novo combustível, salientando que a estatal sugeriu inclusive a criação de uma nova subsidiária, a ALCOBRÁS, o que provocou reações contrárias não só das distribuidoras, como da ANFAVEA, e também da imprensa liberal.

Depois de muita discussão, a estatal recuou no seu propósito de se envolver diretamente na produção do álcool e concentrou seus esforços no controle do sistema de armazenagem e distribuição do produto. 


\subsubsection{A década de 80: a fase final de instalação do Proálcool, o esgotamento dos} recursos governamentais, o descompasso entre a oferta e a demanda de álcool

No início dos anos 80 algumas questões para a implementação do Proálcool ainda estavam pendentes, dentre eles o problema de distribuição e tancagem do álcool hidratado, e da tecnologia dos motores a álcool.

Em março de 1980 foi estabelecido, através de Resolução do CNAL, que os meios de transporte utilizados para o álcool hidratado deveriam ser primeiramente os dutos, depois a cabotagem, seguidos das ferrovias e rodovias, sendo que as rodovias não poderiam ser utilizadas para distâncias superiores a $300 \mathrm{~km}$. Conforme Santos (1993), esta decisão obviamente privilegiava a PETROBRÁS, dado que a estatal já dispunha de um amplo sistema de transporte (oleodutos, petroleiros e caminhões) para os derivados de petróleo, enquanto as Distribuidoras só possuíam caminhões.

Em relação ao sistema de tancagem para o álcool hidratado, foram estabelecidos quatro subsistemas: tanques de produtores (localizados nas usinas e destilarias, com capacidade de armazenagem de até três meses de produção); tanques operacionais (de propriedade das distribuidoras, com capacidade de armazenamento de 15 dias de consumo de sua zona de venda); tanques coletores (pertencentes à PETROBRÁS ou às Distribuidoras, localizados nos centros de coleta e com capacidade para armazenar grandes quantidades de álcool); e, tanques de segurança (a serem usados em situações críticas e com capacidade que, acrescida a $50 \%$ da capacidade dos tanques de coleta, supriria o consumo de 60 dias das áreas circunvizinhas). Portanto, quem detivesse o controle dos tanques coletores, teria o controle do sistema de tancagem.

Em agosto de 1983, através do Decreto № 88.626 , ficou estabelecido que a PETROBRÁS poderia adquirir o volume de álcool necessário para atender à demanda, e que fosse escoado através do seu sistema de transporte, e também o necessário para os estoques de segurança, além de 1/9 do volume de álcool total autorizado para a produção por safra, destinados para uso energético e para estoques de segurança.

Santos (1993) salienta que ao final de 1983 a estatal se aproximava do monopsônio do álcool, já que estava autorizada a comprar o volume que excedia o 
consumo, mais os estoques de segurança e cerca de $50 \%$ de todo o álcool consumido no País (incluindo anidro e hidratado, sendo que em São Paulo e arredores, este percentual chegava a 100\%). Além disso, detinha controle significativo dos tanques coletores (23,5\% da capacidade total de armazenagem, aproximadamente 1,3 milhão de metros cúbicos), e a maior rede de postos de abastecimento de álcool hidratado no País.

Desta forma, os problemas de distribuição e tancagem - considerados gargalos para a implementação do Programa - estavam solucionados, sendo que a partir de 1989 todos os postos receberam permissão do CNP para instalarem bombas de álcool no País.

Restava solucionar o problema da tecnologia dos motores a álcool. A tecnologia dos carros movidos a álcool hidratado foi desenvolvida pelo Centro Técnico da Aeronáutica (CTA) do Ministério da Aeronáutica e pela indústria automobilística, sob a supervisão da Secretaria de Tecnologia Industrial (STI), do Ministério da Indústria e Comércio. Em 1978 as principais montadoras (Volkswagen, Ford, G.M. e Fiat) já produziam os primeiros veículos a álcool.

Quanto aos recursos necessários para a ampliação da capacidade produtiva do álcool, embora o Decreto № 83.700 , de julho de 1979 , estipulasse que os mesmos seriam provenientes de recursos gerados na comercialização do álcool carburante e por dotações provenientes do Governo Federal, era necessária achar outra fonte de recursos, dada a deterioração das condições econômicas do governo.

O Ministério da Indústria e Comércio propôs a entrada de capital estrangeiro para alavancar o Programa (para que a meta de 10,7 bilhões de litros de álcool em 1985 pudesse ser atingida), exercendo forte pressão sobre o capital nacional, além de provocar reações nacionalistas nos militares mais conservadores, alegando que a entrada das multinacionais neste setor era uma ameaça à segurança nacional.

Outros grupos envolvidos (fornecedores de destilarias, a ANFAVEA, os produtores de açúcar e álcool) também manifestaram-se contra, sendo que no final asseguraram ao governo que teriam condições de assumir a meta fixada sem a necessidade de entrada de capital estrangeiro na produção de álcool. 
Conforme Santos (1993), embora o então Ministro do Planejamento Delfim Netto e o Ministro das Minas e Energia das César Cals defendessem a participação do capital externo na produção de álcool, parece claro que o principal objetivo por eles almejado era a contribuição - via investimentos diretos e empréstimos - ao balanço de pagamentos do País.

Ainda estimulado pela necessidade de melhorar o balanço de pagamentos, o Ministro Delfim Netto empenhou-se numa campanha em pról de captar recursos externos para financiar o Programa. Desta forma, em dezembro de 1980, é firmado um acordo entre o Banco Internacional de Reconstrução e Desenvolvimento (BIRD) e o Banco Central com o propósito de oferecer recursos ao Programa, da ordem de US\$250 milhões de dólares, que representavam apenas $4 \%$ do volume total dos recursos necessários.

A partir de 1982, dado os cortes nos gastos públicos, esta fonte, embora não representasse o volume necessários de recursos, era a única disponível para os projetos aprovados. Esta escassez de recursos durante a segunda fase do PNA decorreu da crítica situação econômica pela qual o País passava, o que causou, inclusive, o adiamento da meta de produção de 10,7 bilhões de litros de álcool de 1985 para 1987, e passou a ser um gargalo para a expansão do Programa. Os projetos aprovados pelo CENAL a partir desta data foram feitos com os recursos próprios da iniciativa privada, que tomou empréstimos externos para poder finalizar a implantação das unidades industriais.

Uma outra questão bastante importante para a expansão do programa era a aceitação do carro a álcool pelos consumidores, já que as decisões de investimento da indústria automobilística nesta nova linha de produção baseava-se no comportamento do consumidor. Desta forma, a demanda pelos carros a álcool seria a principal questão a ser resolvida.

A posição das montadoras era no sentido de aguardar a reação dos consumidores para então começarem sua fabricação em série. Diversas reuniões entre as montadoras e o governo aconteceram, sendo que a pressão exercida pelo governo para 
que as mesmas apoiassem o Programa tinha a contrapartida da necessidade da existência de demanda pelo produto.

Portanto, para que as montadoras aceitassem suprir a oferta de carros a álcool, coube ao governo estimular a sua demanda. Dentre os incentivos dados pelo governo são citados os preços menores para o álcool do que a gasolina (inicialmente fixado em $65 \%$ do valor da gasolina); o valor mais baixo da taxa rodoviária única; os prazos mais longos de financiamento para a compra dos carros a álcool; e, a abertura dos postos de abastecimento para carros a álcool durante todo o fim de semana (que eram fechados para a gasolina). Em relação aos preços dos carros a álcool, a ANFAVEA, após negociações com o Conselho Interministerial de Preços (CIP), concordou em vendê-los ao mesmo preço dos carros à gasolina - apesar de seus custos de produção mais altos como forma de estimular o consumo (Santos, 1993).

Porém, em maio de 1980 as metas de produção de veículos a álcool estavam bastante aquém das estabelecidas, fazendo com que os estoques de álcool hidratado aumentassem de forma a exceder a capacidade de armazenamento, resultando na liberação das exportações de álcool. Os principais exportadores foram a COPERSUCAR, os grandes produtores paulistas e até a PETROBRÁS, sendo o álcool vendido ao Japão e Estados Unidos.

Por sua vez, o comportamento do consumidor em relação aos carros a álcool e à gasolina se alterou completamente entre agosto e dezembro 1980: enquanto a demanda pelos carros a álcool aumentou $114 \%$, as vendas de carro à gasolina decresceram $75 \%$ no mesmo período, devido à expectativa de racionamento de gasolina, dado o corte de fornecimento de petróleo pelo Iraque e a Guerra entre Irã e Iraque iniciada em setembro. Segundo Santos (1993), a série de reuniões de emergência realizadas pelo governo, a falta de consenso e as declarações contraditórias das autoridades, levou os consumidores a uma busca frenética pelo carro a álcool.

O consumo mensal de álcool hidratado elevou-se entre setembro e dezembro de 1980 em aproximadamente 60\%, e as vendas de carros a álcool representavam, em dezembro, $76 \%$ do total das vendas de carros novos de passeio. O aumento inesperado 
do consumo deste combustível causava a preocupação quanto à sua possível escassez. Embora o governo garantisse seu abastecimento, através da Resolução da CNE $N^{\mathrm{o}} 10$, de maio de 1980, foi estabelecido uma redução de até $12 \%$ do volume de álcool anidro a ser misturado na gasolina, um teto de produção de veículos a álcool de 350.000 unidades em 1981, e nenhum aumento de cota para conversão de motores no referido ano.

Santos (1993) salienta que é impressionante a alteração do comportamento dos consumidores de carros a álcool: num intervalo de 8 meses, a reação ao carro a álcool se inverte duas vezes: em setembro de 1980, ao iniciar a Guerra Irã x Iraque, as vendas de carros à gasolina correspondiam a $66 \%$ das vendas totais; em dezembro deste ano a situação tinha se invertido completamente, sendo que as vendas de carros a álcool representavam $76 \%$ das vendas totais; e, cinco meses após (maio de 1981), 71\% dos veículos vendidos voltavam a ser movidos à gasolina.

A queda das vendas dos carros a álcool podem ser explicadas por diversos fatores: os efeitos da Guerra entre Irã x Iraque foram menores que os esperados, sendo que a partir do primeiro semestre de 1980 começou haver uma oferta abundante de petróleo no mercado internacional, além de começarem a dar resultados os investimentos feitos na produção nacional de petróleo. Além disso, a crítica situação econômica que o País atravessava e a política anti-inflacionária adotada pelo Ministro do Planejamento Delfim Netto, que alegou que o Programa exercia uma pressão inflacionária na economia impôs ao Proálcool um ritmo mais lento.

Estas questões, associadas às notícias vinculadas na mídia (a conversão de álcool anidro em hidratado; a suspensão das exportações de álcool; a solicitação do Presidente da PETROBRÁS para que se reduzisse a produção de carros a álcool até que a oferta de álcool hidratado se normalizasse), fizeram os consumidores acreditarem numa escassez deste combustível, invertendo a tendência do consumo a favor dos carros à gasolina.

Além destes, Santos (1993) cita a alta dos preços dos carros a álcool - que a partir de dezembro de 1980 deixaram de ser controlados pelo Conselho Interministerial de Preços - e os problemas tecnológicos que começaram a surgir na primeira geração de 
motores a álcool, sendo que estes últimos foram os relatados em uma pesquisa de opinião realizada pela COPERSUCAR e SOPRAL como o motivo principal da rejeição dos carros a álcool.

Em 15 de junho de 1981, através de uma decisão da CENAL, foram suspensos temporariamente todos os contratos de crédito para os projetos de destilarias, devido à falta de verbas. Como consequiência, os estoques de álcool começaram a se elevar (a despeito do aumento de $12 \%$ para $20 \%$ o álcool anidro adicionado na gasolina), e os estoques de álcool hidratado chegaram a 1,3 bilhões de litros ao final de 1981 .

No início de 1982 era grande a preocupação das agências burocráticas e dos grupos de interesses envolvidos com o estoque de álcool acumulado, sendo que os grandes produtores de açúcar e álcool, os fornecedores de equipamentos de destilaria, os fabricantes de automóveis e as retíficas que faziam a conversão de motores se mobilizaram e apresentaram reivindicações ao governo no sentido de retomar as vendas de carros a álcool.

Desta forma, através da Resolução №14, de março de 1982, foram estabelecidas medidas visando a sua recuperação, tais como: decréscimo no teto da relação dos preços álcool/gasolina de $65 \%$ para $59 \%$; aumento do IPI dos carros à gasolina e redução no dos veículos a álcool; e, instalação de densímetros nos postos, para que o consumidor pudesse conferir a qualidade do álcool. Quanto aos preços, a indústria automobilística concordou em vender os carros a álcool pelo mesmo preço que os a gasolina.

Os consumidores reagiram favoravelmente a estas medidas, sendo que as vendas de carros a álcool deram um salto de $59,7 \%$ em abril, de $20,2 \%$ em maio e de $46,9 \%$ em junho (veja figura 6 , a seguir). É interessante notar que os consumidores reagiam imediatamente às políticas de incentivo e desincentivo ao Programa (fazendo com que as tendências se revertessem em poucos meses e a oscilação da demanda fosse bastante importante), o que indicava a importância do consumidor no sucesso do Programa. 
Outra medida de grande impacto para a recuperação das vendas dos carros a álcool foi o Decreto-Lei №1944, de junho de 1982, que isentou de IPI, pelo prazo de um ano, os carros de passageiros movidos a álcool, de até $100 \mathrm{HP}$, a serem utilizados como táxis. Os estímulos dados ao mercado dos táxis provocou uma revitalização das vendas de carros a álcool, fazendo com que a indústria automobilística finalmente manifestasse credibilidade no produto.

Ao término de 1982, o mercado de carros a álcool estava superaquecido, representando $38 \%$ das vendas totais de carros de passageiros, sendo que em dezembro este percentual chegou a $67 \%$. Os consumidores, a partir de 1984, mostravam claramente ter aderido ao carro a álcool. A figura 6, elaborada a partir de dados da UNICA, traz a evolução das vendas de carros entre 1980 e 1994.

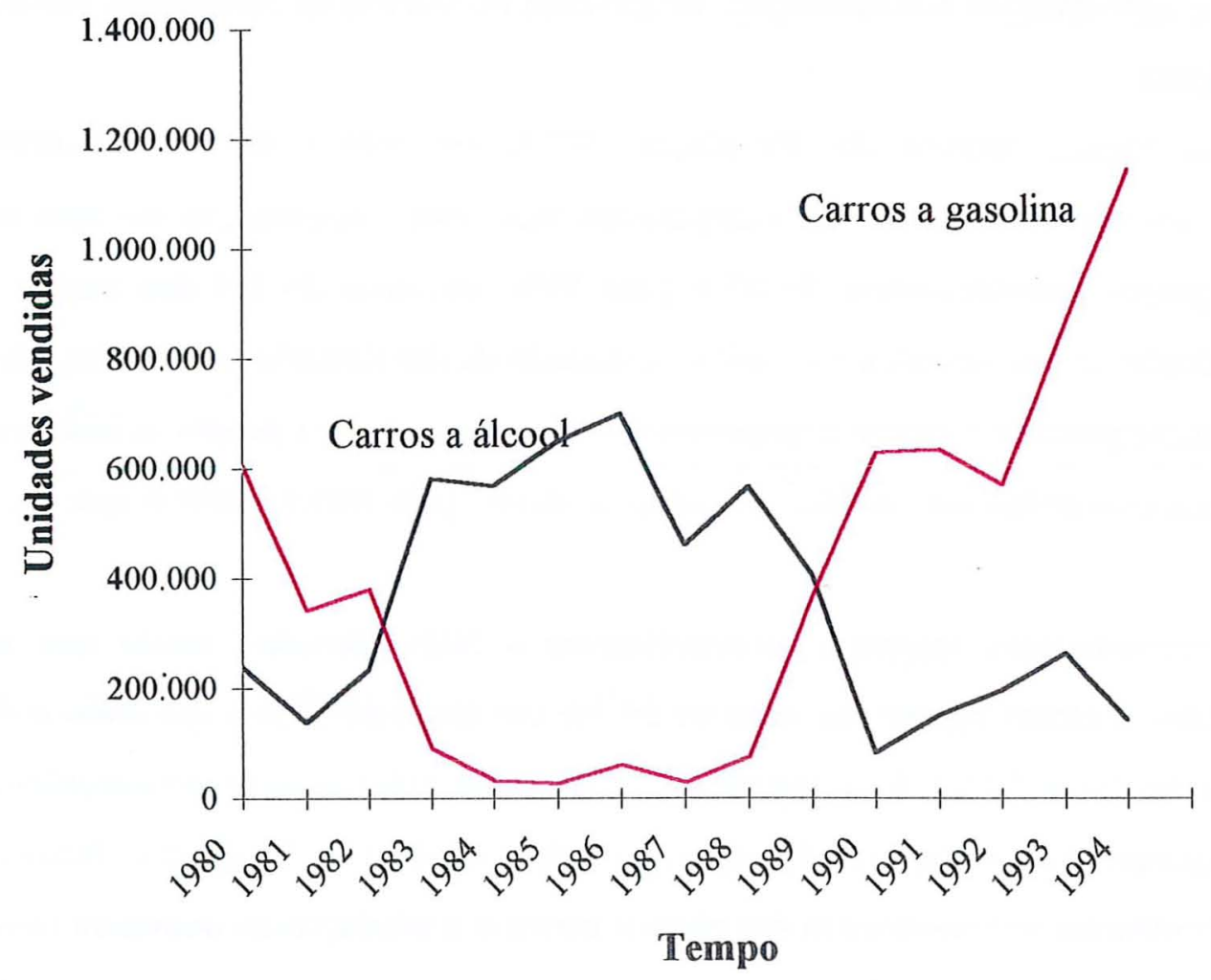

Figura 6 - Evolução das vendas de carros a álcool e a gasolina. 
Nota-se que entre os anos de 1983 e 1989 as vendas de veículos a álcool representavam, em média, 90\% das vendas de carros totais. A partir de 1989 esta proporção começou a diminuir (provavelmente devido à crise de faita do álcool ocorrido neste época) e já em 1990 a porcentagem de vendas de veículos a álcool em relação ao total representava apenas $11,04 \%$.

Em 1995 esta porcentagem passou a representar somente 2,19\% das vendas totais, sendo que nos dias de hoje esta proporção corresponde a menos de $1 \%$. Atualmente, de uma frota estimada em 15 milhões de carros no Brasil, apenas 3,8 milhões são movidos a álcool ${ }^{23}$, cuja vida útil estimada se encerra no ano 2005 , já que a produção atual é praticamente nula.

Em relação à produção de álcool, entre 1975 e 1983 ela passou de 580 milhões de litros para 7,95 bilhões, sendo que a capacidade instalada do parque alcooleiro aumentou de 904 milhões para 11,1 bilhões de litros por safra.

A produção alternativa de álcool fez com que houvesse um deslocamento da cana-de-açúcar da produção de açúcar para a de álcool. Conforme Santos (1993), no início da década de 70,96\% do álcool produzido era indireto (subproduto do açúcar), a partir da criação do PNA, cresceu a importância do álcool dentro da agroindústria canavieira, sendo que na safra de 1985/86, mais de $60 \%$ da cana-de-açúcar foi usada para a fabricação de álcool.

A partir de 1986 diversos fatores contribuíram para que se iniciasse-se uma fase de avaliação do Programa. Conforme Santos (1993), desde de janeiro daquele ano os preços internacionais do petróleo começam a declinar; a produção interna crescente do produto diminuía a dependência do país em relação ao petróleo importado; e os planos econômicos do governo priorizavam o controle da inflação e do déficit público, evidenciando que a expansão do Programa deveria ser feita através de aumento de produtividade das atividades agrícolas e industrial, já que os financiamentos governamentais para a ampliação da capacidade instalada estavam suspensos.

\footnotetext{
${ }^{23}$ Veja Gazeta Mercantil Latino Americana, 4 a 10 de maio de 1998, pág.14.
} 
O esgotamento das fontes oficiais de recursos evidenciou a dificuldade do governo continuar a intervindo no setor, e os conflitos entre produtores e governo indicavam a necessidade de um novo modelo de intervenção governamental.

Em outubro de 1987, devido ao déficit da conta álcool ${ }^{24}$, a PETROBRÁS decidiu parar de comprar qualquer estoque de álcool superior a demanda, paralisando o pagamento aos produtores, não obstante o Decreto-lei № 94.541 , de julho de 1987 , estabelecesse que era obrigatória a compra de estoques de segurança (que haviam se escoado devido ao pico de consumo ocorrido no Plano Cruzado), e do volume além da demanda segundo regras nele estabelecidas.

Os produtores de álcool, por sua vez, além das dificuldades causadas pelas medidas adotadas pela PETROBRÁS, queixavam-se da defasagem de preços dos produtos. Embora estes preços fossem baseados em levantamentos de custos feitos pela Fundação Getúlio Vargas, eles eram determinados conjuntamente pelo Conselho Nacional do Petróleo e pelos órgãos do governo responsáveis pela política econômica, que era uma política anti-inflacionária, de contenção dos preços públicos. Estes fatores causaram, a partir da safra de 1985/86 uma estagnação tanto da produção de cana como na de álcool, enquanto o consumo cresceu $12 \%$.

Conforme Santos (1993), na safra de 1989/90, cerca de 28 destilarias autônomas, financiadas pelo Proálcool tinham fechado, significando uma redução da ordem de 500 milhões de litros de álcool. Neste mesmo ano os fornecedores de cana e os próprios produtores de álcool ameaçavam parar a produção. Além disto, surgiram conflitos entre fornecedores de cana e usineiros e denúncias de comercialização clandestina de álcool. A situação se agravou mais quando a PETROBRÁS reduziu radicalmente seus estoques de álcool, o que acabou gerando uma crise de desabastecimento do produto, sendo que no final de 1989 os consumidores deparavamse com grandes filas nos postos.

Embora o governo tivesse tomado algumas medidas para aliviar a crise de abastecimento - redução do teor de álcool anidro (passou de $22 \%$ para 13\%) usado na

\footnotetext{
${ }^{24}$ A explicação do déficit da conta álcool encontra-se em Santos (1993), pág. 236/237.
} 
mistura álcool-gasolina; importação de metanol; e, substituição do álcool anidro pelo MTBE - as filas voltaram a se formar na entressafra de 1990, quando novamente houve a escassez do combustível.

Desta forma, aconteceu mais uma reversão no comportamento do consumidor, e as vendas de carros a álcool - que durante quatro anos chegaram a representar $90 \%$ das vendas totais - começam a declinar a partir de 1988 (veja a Figura 6). A redução da demanda pelos carros a álcool e a crise econômica enfrentada pelo País acabaram equilibrando o mercado de álcool combustível.

As crises de abastecimento de álcool de 1989 e 1990 evidenciaram a forte dependência da PETROBRÁS em relação ao álcool anidro (que era (é) misturado à gasolina em substituição ao chumbo tetraetila, para garantir a octanagem da gasolina), sendo que a estatal passou a defender o uso do MTBE em substituição àquele produto.

Enquanto o conflito entre a PETROBRÁS e os produtores de álcool crescia, a questão ambiental começava a tomar força, fortalecendo a posição dos produtores de álcool, já que este é considerado um "combustível limpo". O uso de combustíveis oxigenados - com o objetivo de reduzir a emissão de $\mathrm{CO}_{2}$ - passou a ser uma tendência nos países desenvolvidos a partir. No Brasil, o controle da emissão de poluentes é feito pela CETESB, que passou a ser um importante aliado do álcool combustível.

Embora o Proálcool tenha conseguido sucesso em relação à produção de álcool (na primeira fase a produção de álcool hidratado passou de 323 milhões de litros em 1975/76 para mais de 8,6 bilhões de litros em 1985/86, sendo que em 1991/92 a mesma atingiu aproximadamente 10,8 bilhões de litros), em agosto de 1990, o então Presidente Collor, embora negasse a extinção do Programa, reconhecia a limitação do álcool como substituto de todos os derivados de petróleo, optando por manter a produção de álcool dentro de sua capacidade já instalada. Quanto ao petróleo, salientava a necessidade de fornecer recursos à PETROBRÁS para aumentar a produção nacional.

A coexistência de dois tipos de combustíveis competindo no País, e de interesses opostos, da PETROBRÁS e dos produtores de álcool, evidenciou a 
necessidade de atuação do governo como mediador dos conflitos, de forma a desenhar uma política para os combustíveis que atendesse aos interesses do País.

No início dos anos 90, com a abertura comercial do País aos mercados externos, e a caracterização da falência do Estado Brasileiro, fica claro o esgotamento do modelo de intervenção estatal anteriormente existente, principalmente quando se consideram as mudanças ocorridas no ambiente institucional do País, que caminha em direção a consolidação do regime democrático. 


\section{A DESREGULAMENTAÇÃO DO SETOR}

A partir da reforma administrativa do Governo Collor, um novo aparato institucional para a política decisória do álcool e do açúcar foi estabelecido, dentro de um contexto de liberalização econômica do País como um todo, apoiado na Constituição Federal de $1988^{25}$.

Conforme a referida Constituição, o papel de interventor do Estado na economia brasileira alterou-se significativamente, já que ela estabeleceu que o planejamento estatal deve ter somente caráter indicativo, o que acabou por enfraquecer a ação governamental, e, no setor sucroalcooleiro, a força do Instituto do Açúcar e do Álcool (IAA).

Os efeitos do processo de liberação no setor sucroalcooleiro fazem-se sentir no seu ambiente institucional e organizacional; nos sistemas de fixação de preços dos insumos e produtos desta cadeia e nas suas formas de comercialização (incluindo a sexportações); nos controles de produção e Planos de Safra até então emitidos pelo governo; nas políticas de sustentação do álcool combustível e da cana-de-açúcar, e no próprio modo de atuação dos diversos agentes envolvidos (incluindo os Governos Federal e Estaduais).

Nesta seção procura-se mostrar o processo da desregulamentação que o setor está atravessando e seus efeitos sobre a cadeia sucroalcooleira.

\footnotetext{
${ }^{25}$ A Constituição Federal de 1946 consagrou o princípio intervencionista do Estado na economia, que foi mantido na Constituição de 1967. Por sua vez, a Constituição de 1988 dispõe de forma diametralmente oposta (Bezerra, R.C. Parecer sobre os dispositivos legais da legislacão intervencionista do setor sucroalcooleiro. São Paulo, 1997. Parecer técnico apresentado à UNICA, São Paulo).
} 


\subsection{A Mudança Institucional: o processo de liberação, a legislação pertinente e os diversos adiamentos}

A publicação da Lei № 8.178 , de março de 1991, que estabeleceu regras sobre preços e salários, foi de fundamental importância para o processo de desregulamentação da economia brasileira iniciado no Governo Collor.

Embora sưa abrangência não fosse exclusiva ao setor sucroalcooleiro, ela conferiu ao Ministro da Economia, Fazenda e Planejamento o poder de "baixar, em caráter especial, normas que liberem, total ou parcialmente, os preços de qualquer setor", o que permitiu que futuramente ações mais concretas neste sentido fossem tomadas.

\subsubsection{A Portaria do Ministério da Fazenda № 64 (março de 1996)}

Em relação aos preços dos produtos da cadeia sucroalcooleira, em março de 1996, seguindo a lógica mais ampla da política governamental de liberação dos preços do setor de combustíveis, o Ministro da Fazenda Pedro Malan emitiu a Portaria № 64 , que estabeleceu que "Ficam sujeitos ao regimes de preços liberados, ... os preços da cana-de-açúcar, inclusive os fretes, fornecida às usinas e destilarias autônomas de todo o País, do açúcar cristal standard ${ }^{26}$, do álcool para fins carburantes de todos os tipos, do álcool para fins não carburantes de todos os tipos e do mel residual, nas unidades produtoras", sendo $1^{\circ}$ de janeiro de 1997 a data estabelecida para que a Portaria entrasse em vigor.

A partir da emissão desta Portaria que liberava os preços diversas questões emergiram, principalmente aquelas ligadas à continuidade do uso do álcool hidratado como combustível e da frota de carros à álcool, já que o álcool combustível não é competitivo com a gasolina a preços de mercado.

Esperava-se que a partir da liberação em janeiro de 1997, os produtores e as distribuidoras de combustíveis trabalhassem através de contratos anuais de fornecimento, sendo a entrega do produto e as quantidades compradas estabelecidas

\footnotetext{
${ }^{26}$ Deve ser notado que na prática, o açúcar no mercado interno já era comercializado em ambiente de livre mercado, já que o produto regulado pelo governo, o açúcar cristal standard, não é produzido pela maioria das usinas.
} 
diretamente entre as partes, e que seus preços passassem a ser estabelecidos entre negociação entre os produtores e as distribuidoras.

Em relação ao álcool anidro, existe uma reserva de mercado proporcional ao consumo de gasolina observado no País, criada pela própria legislação, que estipula que ele seja misturada à gasolina em determinadas proporções. Conforme a Medida Provisória MP № 1.867-17, de setembro de 1999 (que dá nova redação ao artigo $9^{\circ}$ da Lei № 8.723 , de outubro de 1993, que refere-se à redução de emissão de poluentes), o percentual de álcool anidro a ser fixado à gasolina em todo o território nacional é de $22 \%$, podendo o Poder Executivo elevar este percentual até $24 \%$.

Porém, em relação ao álcool hidratado, com a liberação dos preços previstas para janeiro de 1997, surgiram muitas preocupações relativas a própria continuidade do uso do produto, já que em termos estritamente econômicos ele não é competitivo com a gasolina, e num regime de preços liberados ele provavelmente não se sustenta sem o mecanismo de suporte de preços atualmente existente (através da Parcela de Preços Específica, administrada pela Agência Nacional do Petróleo), que foi mantido somente até agosto do ano 2000 , conforme a lei $\mathrm{N}^{\mathrm{0}} 9.478$, que determinou a flexibilização do monopólio da PETROBRAS.

\subsubsection{O $1^{\text {o }}$ adiamento da liberação: a Portaria do Ministério da Fazenda № 294 (dezembro de 1996)}

Em meio a estas discussões, em dezembro de 1996 um novo cronograma para a liberação de preços do setor foi anunciado, através da Portaria do Ministério da Fazenda $N^{0} 294$ (que revogava a Portaria de $\mathrm{N}^{0}$ 64). Desta forma, a liberação dos preços da canade-açúcar, do açúcar e do álcool, previstos para $1^{0}$ de janeiro de 1997, foi prorrogada, sendo que estabeleceram-se datas distintas para a liberação do álcool anidro e a dos demais produtos.

Conforme a Portaria $\mathrm{N}^{\mathrm{Q}} 294$, os preços do álcool anidro estariam liberados a partir de $1^{\circ}$ de maio de 1997 (o que realmente aconteceu) e os preços da cana-de-açúcar, 
do açúcar cristal standard, do álcool de todos us tipos (com exceção do anidro) e do mel residual passariam a ser livres a partir de $1^{2}$ de maio de 1998.

Das razões levantadas para o adiamento destacaram-se a preocupação do Ministério da Fazenda com a perda da renda dos produtores; a de que aumentos de preço do produto poderiam aumentar a inflação; e, que a liberação dos preços do álcool precisaria ser precedida de ajustes operacionais (por exemplo, a discussão sobre a privatização dos dutos da Petrobrás).

Conforme a Exposição de Motivos do então Ministro da Indústria, do Comércio e do Turismo, Francisco Dornelles ${ }^{27}$, a liberação dos preços sem um mecanismo tributário de suporte aos preços do álcool combustível prejudicaria sensivelmente os produtores e consumidores deste produto, já que representaria um aumento de $25 \%$ sobre o preço final do combustível para os 4,3 milhões de consumidores, e uma redução de $70 \%$ das atividades do setor, com redução de aproximadamente 560 mil postos de trabalho.

De qualquer forma, o adiamento trouxe um prazo maior para que as questões fossem discutidas, e o setor se preparasse para enfrentá-la, embora tenha se estabelecido uma confusão no setor: ao mesmo tempo em que os preços do açúcar (mercados interno e externo) e do álcool anidro estavam liberados, os preços do álcool hidratado e da cana mantiveram-se tabelados.

\subsubsection{O $2^{o}$ adiamento da liberação: a Portaria do Ministério da Fazenda № 102 (abril de 1998)}

Dois dias antes da Portaria № 294 entrar em vigor, foi emitida, em 28 de abril de 1998, a Portaria do Ministério da Fazenda № 102, prorrogando novamente a data de liberação dos preços da cana-de-açúcar, do açúcar cristal standard, e do álcool hidratado para fins carburantes, para $1^{\circ}$ de novembro de 1998.

\footnotetext{
27 "Álcool tem adiada a liberação de preços". Folha de São Paulo, caderno dinheiro, p.5, 26/11/1996.
} 
Segundo a própria Portaria, o adiamento da data de liberação destes produtos fez-se necessária devido a necessidade de realização de um amplo diagnóstico do setor sucroalcooleiro, com vistas a identificar e corrigir desequilíbrios estruturais do setor.

Além destas, a existência dos elevados estoques de passagem de álcool carburante (com reflexos negativos sobre os preços); a necessidade de definir regras ou padrões de comercialização de álcool carburante antes da liberação total do mercado; e a necessidade de aprofundar as discussões sobre a comercialização da cana-de-açúcar em ambiente de liberdade de preços, foram razões também citadas na referida portaria para o adiamento da liberação dos preços.

A emissão da Portaria № 102, às vésperas data de liberação dos preços, trouxe muito desentendimento ao setor, tanto entre os fornecedores de cana-de-açúcar e usinas e destilarias, como entre estes últimos e as distribuidoras, já que grande parte dos agentes da cadeia sucroalcooleira já tinham se preparado para começar a operar em ambiente de livre mercado (conforme mostrado nas próximas seções).

\subsubsection{O 3ª adiamento da liberação: a Portaria do Ministério da Fazenda № 275} (outubro de 1998)

Em 16 de outubro de 1998, através da Portaria do Ministério da Fazenda № 275 , foi postergada por mais três meses a data da liberação dos preços da cana-de-açúcar, do açúcar cristal standard, do álcool hidratado para fins carburantes, de álcool para fins não carburantes e o do mel residual, passando a data de liberação de $1^{\circ}$ de novembro de 1998 para $1^{0}$ de fevereiro de 1999.

Além da nova data de liberação, a referida Portaria estabeleceu os preços-base da cana-de-açúcar a vigorarem a partir de $1^{\circ}$ de novembro (que é diferenciado por estado ou região) e estipulou o valor do suporte aos produtores de cana dos estados do Nordeste.

Neste mesmo dia, foi emitida a Resolução do $\operatorname{CIMA~N}^{0}$, que estipula o limite de recursos passíveis de utilização com gastos com o Programa do Álcool em 1999. Foi determinada uma redução no volume total anual do dispêndio, que passou de $\mathbf{R} \$ 1,3$ 
bilhão de reais para $\mathrm{R} \$ 1,1$ bilhão de reais, sendo que os recursos financeiros são oriunḍos da conta Parcela de Preço Específica (PEP), administrada pela ANP. Além disso, a referida Resolução estipula que o Comitê Executivo implementaria as medidas de desregulamentação do setor apresentadas ao CIMA.

Segundo os técnicos do governo, o mercado de álcool ainda não estava ajustado para uma liberação imediata ${ }^{28}$. Outros motivos alegados foram a necessidade de se estudar o mecanismo de repasse do suporte (pago pela ANP) e a cobrança do Imposto sobre Circulação de Mercadorias e Serviços (ICMS), pretendendo-se repassar o subsídio diretamente às usinas e destilarias, já que o sistema então vigente, no qual as distribuidoras de combustíveis recebiam o subsídio e abatiam este valor do ICMS devido, podia gerar fraudes.

\subsubsection{A liberação dos preços: fevereiro de 1999}

Finalmente, em $1^{\text {o }}$ de fevereiro de 1999, instalou-se o sistema de preços liberados, tanto para a cana-de-açúcar como para todos os produtos da agroindústria sucroalcooleira.

Os diversos adiamentos da liberação do setor sucroalcooleiro, as discussões e participação ativa dos agentes envolvidos, bem como as notícias veiculadas na mídia deixam claro as dificuldades encontradas neste processo, no sentido de se equilibrar as questões econômicas, ambientais e sociais envolvidas.

Devem ser ressaltadas as fortes pressões e contra-pressões dos diversos segmentos envolvidos, seja no sentido de apoio à liberação econômica (requerida pelos produtores mais eficientes, dispostos a enfrentar as regras de livre mercado), seja no sentido inverso, o da manutenção do sistema então vigente, no qual a continuidade da produção em regiões comparativamente menos eficientes (nas diversas etapas da cadeia produtiva), ainda depende do apoio governamental.

\footnotetext{
28 "Mercado livre para a cana é adiado". O Estado de São Paulo, p. G-4, 21/10/1998.
} 


\section{$4.2 \mathrm{~A}$ legislação ambiental}

Embora não seja o foco central deste trabalho, certamente uma questão que está causando fortes impactos ao setor, tanto no que se refere aos investimentos necessários para a mecanização, como no desemprego decorrente, é a proibição das queimadas de cana-de-açúcar como método de despalha.

A queima da cana-de-açúcar como método de despalha é uma atividade secular, que é feita também em outros países produtores de açúcar, em variadas proporções (México, África do Sul e Havaí queimam 100\% da cana; Colômbia, 95\%; Argentina, 90\%; Austrália, 40\% e Cuba, 5\%, conforme Silva, 1997).

Embora a questão das queimadas da cana-de-açúcar já venham sendo discutidas há bastante tempo no Estado de São Paulo (o Decreto Estadual № 28.848, de 1988, proíbe a queima da cana-de-açúcar como método de despalha num raio de $1 \mathrm{~km}$ da área urbanizada), foi a partir da emissão do Decreto Estadual №42.056, de agosto de 1997, que a questão da queima da cana passou a causar um impacto maior ao setor.

O Decreto Estadual №42.056, que regulamenta a queimada da cana-de-açúcar, institui a eliminação da queima da cana-de-açúcar com o seguinte cronograma: em áreas mecanizáveis (aquelas com declividade inferior a 12\%), a redução da queima da canade-açúcar deve ser feita num prazo de 8 anos (redução de $25 \%$ a cada dois anos, exigindo-se mínimo de redução de $10 \%$ no $1^{0}$ ano). Conforme Souza (1998), as áreas mecanizáveis correspondem a $60 \%$ da atual área cultivada com cana no Estado de São Paulo.

Para as áreas não mecanizáveis e para áreas inferiores a 125ha (que abrangem 93\% dos fornecedores paulistas), o referido decreto estipula que a redução bianual será de $13,35 \%$, o que corresponde a um prazo para a extinção total de 15 anos.

O corte manual da cana crua (com a palha) é inviabilizado pelo seu alto custo de produção (em média $45 \%$ maior que o da cana queimada) e pelo Acordo Seletivo do Trabalho, que prevê a queima da cana para o corte, dadas as dificuldades para colher a cana crua. Desta forma, a solução mais econômica para se colher a cana crua é através da colheita mecanizada. 
Porém, as dificuldades encontradas pelos produtores de cana quanto ao cumprimento do Plano de Eliminação de Queimadas advém da falta de recursos para adquirir as colhedeiras mecânicas, devido a falta de financiamento, além das condições topográficas de algumas regiões, que impossibilitam a colheita mecanizada.

Os produtores da cana do Estado de São Paulo, dadas as dificuldades encontradas em cumprir o cronograma da eliminação das queimadas estipulado no Decreto Estadual №42.056/97, entregaram uma proposta à Câmara Paulista do Setor Sucroalcooleiro, no sentido de adequar o Decreto Estadual Nㅃ42.056/97 aos Decretos Federais №2.661/98 e №3010/99.

Estes decretos federais regulamentam o uso do fogo na agricultura e na cana-deaçúcar (como método de despalha) e permitem a queima em propriedades até 100ha e com declividades maiores que $12 \%$. Ao final de 10 anos, estima-se que a adequação aos decretos federais evitaria o desemprego de aproximadamente 90.000 trabalhadores no Estado de São Paulo.

Por sua vez, a Lei de Política Nacional do Meio Ambiente №6.938, de 1981, proíbe a queimada da cana ao ar livre, considerando que esta prática produz impactos negativos no meio ambiente e na saúde pública.

O Ministério Público do Estado de São Paulo, tomando como base a referida lei, vem autuando o produtor de cana num raio maior do que o estipulado no Decreto Estadual № 28.848, salientando os altos os custos sociais e econômicos decorrentes da queimada, que são pagos pelos contribuintes, tais como: os custos envolvidos no atendimento, na rede pública, de doenças respiratórias causadas pela alta concentração dos gases tóxicos provenientes das queimadas; os custos do aumento do consumo de água tratada (que aumenta em decorrência da fuligem produzida pelas queimadas); os prejuízos causados pela interrupção de energia devido ao fogo das queimadas atingirem as redes de alta tensão, etc.

As diversas questões envolvidas: as ambientais e de saúde, o desemprego gerado pela substituição da mão-de-obra pela colheita mecânica, a falta de linhas de financiamento para a aquisição de colhedeiras mecânicas, o deslocamento da produção 
para regiões mais adequadas à colheita mecanizada, dentre, outras, requerem que o problema seja refletido com cautela não somente pelas autoridades, como pela sociedade como um todo, para que os prazos estipulados para a eliminação das queimadas atendam as demandas de toda a sociedade.

Porém, é importante lembrar que a redução dos custos decorrentes da adoção da colheita mecanizada será um fator de competitividade decisivo, que influenciará não só a escolha entre a colheita mecanizada ou manual, como também na determinação das novas regiões economicamente mais viáveis para a cana-de-açúcar.

Desta forma, espera-se que mais cedo ou mais tarde a colheita mecânica se estenda a todos os canaviais, o que implica na necessidade de programas de requalificação de mão-de-obra, e de alternativas de produção para os pequenos fornecedores que não tenham capacidade de mecanizar-se, ou para aquelas áreas cujas condições topográficas impeçam a mecanização.

\subsection{As mudanças no ambiente organizacional público}

\subsubsection{A extinção do Instituto do Açúcar e do Álcool (IAA)}

Em 15 de março de 1990, várias entidades da Administração Pública Federal foram extintas (conforme a Medida Provisória $\mathrm{N}^{0} 151$ ), dentre elas o Instituto do Açúcar e do Álcool (IAA), sendo que a transferência das atribuições do Instituto aos órgãos e entidades da Administração Pública Federal ficou a cargo do Presidente da República.

Até que o processo de extinção fosse concluído, o IAA ficou vinculado ao Ministério da Economia, Fazenda e Planejamento. As atribuições do IAA foram transferidas para a Secretaria do Desenvolvimento Regional da Presidência da República, em junho de 1990, através do Decreto № 99.288.

Desta forma, foi extinta uma entidade que por quase 60 anos participou ativamente do processo de intervenção estatal na economia sucroalcooleira, e apesar dos protestos de alguns produtores e fornecedores de cana, não mais seria possível recompor o IAA, não só devido à tendência de liberação econômica do Governo Collor, mas também porque a Constituição de 1988 não permitia outro caminho. 
Em abril de 1991 foi aprovada a Estrutura Regimental da Secretaria do Desenvolvimento Regional da Presidência da República, cujas atribuições seriam prestar assistência direta e imediata ao Presidente da República. Especificamente em relação ao setor sucroalcooleiro, a Secretaria deveria supervisionar, controlar e normatizar as suas ações.

Em julho de 1991, através de Portaria da Secretaria de Desenvolvimento Regional da Presidência da República, foi criada a Comissão Consultiva Nacional de Açúcar e Álcool, com a finalidade de assessorar o Secretário do Desenvolvimento Regional nas competências relativas ao setor sucroalcooleiro.

Faziam parte desta Comissão representantes dos Ministérios da Economia, da Agricultura e da Infra-Estrutura, das Secretarias de Ciência e Tecnologia e de Assuntos Estratégicos da Presidência da República, além do Diretor do Departamento de Assuntos Sucroalcooleiro da SDR/PR (que serviria de Secretário Executivo), e de representantes da indústria privada de açúcar e álcool, dos fornecedores de cana e dos trabalhadores do setor.

Segundo Santos (1993), a reforma administrativa do Governo Collor, do ponto de vista da política do álcool, manteve a mesma estrutura decisória fragmentada verificada anteriormente, sendo que destacavam-se três centros decisórios: a Secretaria de Desenvolvimento Regional (SDR), que ficou responsável pelos aspectos da produção do álcool, do açúcar e da cana, antigas atribuições do IAA; o Departamento Nacional de Combustíveis (DNC), que substituiu o Conselho Nacional do Petróleo (CNP), e continuou a ser o responsável pela política de abastecimento de combustíveis (distribuição do álcool e dos derivados de petróleo); e o Ministério da Economia, incumbido de estabelecer os preços da cana, álcool, açúcar e dos derivados do petróleo (a partir das propostas do SDR e do DNC), e que controlava os instrumentos de política fiscal e creditícia.

Em relação às diferenças da estrutura decisória anterior, a autora salienta que este novo aparato institucional apresentava uma tendência às decisões colegiadas, sendo que tanto o DNC como a SDR constituíram grupos de trabalho (com representantes dos 
produtores de açúcar e álcool, da PETROBRAS, da ANFAVEA, e do SINDICOM), nos quais discutiam-se as divergências dos diversos grupos envolvidos.

Em abril de 1993 foi criada, através de um Decreto Presidencial, uma nova Comissão Interministerial - coordenada pelo Ministério das Minas e Energia - com o objetivo de definir e regulamentar os instrumentos de política do álcool combustível. Desta Comissão faziam parte os Ministérios da Fazenda, da Agricultura, Indústria e Comércio, Integração Regional, Secretaria de Planejamento e Banco do Brasil.

O Departamento Sucro-Alcooleiro, responsável por algumas das atribuições do extinto IAA, fazia parte do Ministério da Integração Regional, e funcionou como canal de ligação entre os produtores e o Palácio do Planalto.

Embora apresentando maior tendência às decisões colegiadas, deve ser notado que o sistema de tomada de decisões relativas ao setor continuava bastante fragmentado, dificultando o processo.

\subsubsection{A criação do Conselho Interministerial do Açúcar e do Álcool (CIMA)}

Os esforços do governo no sentido de mudar o sistema descentralizado de tomadas de decisões resultou numa alteração significativa do seu ambiente institucional. Em agosto de 1997 (através do decreto s/nº, DOU de 22/08/97), foi criado o Conselho Interministerial do Açúcar e do Álcool (CMA), com o objetivo de analisar e propor políticas relativas ao setor sucroalcooleiro. O CIMA é composto por dez ministros e pelos respectivos Secretários Executivos de cada Ministério, sendo que os últimos, juntamente com um representante da Casa Civil da Presidência da República, compõe o Comitê Executivo do CIMA.

Procurou-se, portanto, centralizar as ações governamentais referentes ao setor, de tal forma que as decisões, pertinentes aos diversos ministérios, pudessem ser tomadas conjuntamente, a partir de um diagnóstico mais preciso da realidade do setor, de maneira que elas pudessem ser as mais acertadas possíveis.

Na mesma época foi criado o Comitê Consultivo para a Política Sucroalcooleira do CIMA (através da Portaria do MICT № 107, de agosto de 1997), formado por 
representantes dos produtores de açúcar e álcool, dos fornecedores de cana, e posteriormente por parlamentares da Câmara dos Deputados e Senadores, cuja opinião é ouvida pelo Comitê Executivo, antes das decisões serem passadas para os ministros que compõe o CIMA referendarem.

Em maio de 1997 os preços do álcool anidro já estavam liberados, e o mercado já começava a sentir os reflexos da liberação do produto. Além disso, havia a previsão da liberação dos preços do álcool hidratado para maio de 1998. Porém, conforme Serodio (1999), as decisões nesta época ainda estavam sendo tomadas de maneira fragmentada e era necessário um conhecimento mais aprofundado dos problemas enfrentados pelo setor, de forma que as deliberações pudessem ser tomadas de forma mais adequada.

Neste sentido, foi contratada uma assessoria técnica, sob coordenação do Ministério da Indústria, do Comércio e do Turismo, para elaborar um trabalho sobre o setor $^{29}$, que passou a servir de referência para as futuras discussões e decisões tomadas pelo CIMA. Embora o processo de desregulamentação já se encontrasse em estágio avançado, alguns entraves foram diagnosticados no referido trabalho, apresentados em (Serodio, 1999):

- Oferta excedente de matéria-prima;

- Alto grau de flexibilidade entre produzir álcool ou açúcar (que pode ser uma vantagem, mas também um complicador em conjuntura de super-oferta de um dos produtos);

- Custos de produção do álcool demandando proteções para competir com a gasolina;

- Diferentes graus de competitividade entre produtores tanto por custos de matéria-prima mais elevados em algumas regiões como pela localização das fábricas;

- Importante excedente de álcool na safra 98/99 (ou seja, na origem da desregulamentação).

\footnotetext{
${ }^{29}$ SERODIO et al Propostas de políticas públicas para o setor sucroalcooleiro - do monopólio ao livre mercado. Brasília, Departamento de Açúcar e Álcool do MICT, 1998.
} 
A partir deste trabalho, foi feito um amplo diagnóstico das dificuldades a serem enfrentadas pelo setor num ambiente de livre mercado, como também foram dadas diversas sugestões para que a transição pudesse ocorrer de forma menos danosa possível (algumas destas sugestões foram acatadas futuramente nas Resoluções do CIMA, em especial a de $\mathrm{N}^{\mathrm{0}} 10$ ).

Em fevereiro de 1999, através da Resolução da Secretaria-Executiva do CIMA №1, foi criada a Câmara Técnica do CIMA, com o objetivo de dar suporte às medidas que são levadas ao CIMA. A Câmara Técnica é composta por seis especialistas indicados por produtores de açúcar e álcool, dois indicados por plantadores de cana e um por entidades de classe dos trabalhadores da agroindústria, e designados pelo Secretário Executivo do CIMA. A relação dos Ministros, dos Secretários Executivos, dos membros do Conselho Consultivo e da Câmara Técnica do CIMA estão relacionados no Anexo A.

Atualmente, o fluxo das decisões tomadas pelo CIMA tornou-se o seguinte: primeiramente as questões são debatidas pela Câmara Técnica do CIMA, que após analisar e discutir o problema o envia ao Comitê Executivo. O Comitê Executivo (composto pelos Secretários Executivos dos Ministros que compõe o CIMA) analisa as questões, discute com o Comitê Consultivo, e após chegarem a uma conclusão sobre o assunto, levam para decisão final dos Ministros que compõe o CIMA. É interessante salientar que as resoluções deste conselho tem força de decreto.

Em julho de 1999, com a reforma Ministerial feita pelo presidente Fernando Henrique Cardoso, o Departamento do Açúcar e do Álcool foi transferido do Ministério da Indústria, Comércio e do Turismo para o Ministério da Agricultura e do Abastecimento, sendo que os assuntos referentes ao açúcar e álcool estarão inseridos na Secretaria de Produção e Comercialização do referido Ministério.

Em setembro de 1999, através do Decreto № 3.159/99, a presidência do CIMA foi transferida para o Ministro da Agricultura e do Abastecimento, sendo que na nova estruturação do Conselho foram excluídas a Secretaria de Assuntos Estratégicos e da Casa Civil, ambas da Presidência da República. 
Desta forma, passam a fazer parte do CIMA os seguintes Ministérios: Ministério da Agricultura e do Abastecimento; Ministério da Fazenda; Ministério do Planejamento, Orçamento e Gestão; Ministério do Desenvolvimento, Indústria e Comércio; Ministério das Minas e Energia; Ministério do Meio-Ambiente; Ministério das Relações Exteriores; e, Ministério da Ciência e Tecnologia.

\subsubsection{A criação da Agência Nacional do Petróleo (ANP) e a abertura do mercado de combustiveis}

Em agosto de 1997 foi promulgada a Lei № 9.478 , que dispõe sobre a política energética nacional, as atividades relativas ao monopólio do petróleo, institui o Conselho Nacional de Política Energética, cria a Agência Nacional do Petróleo, e que objetiva implantar o regime de livre mercado para os combustíveis derivados de petróleo, a partir de agosto de 2.000. O Decreto № 2455 , de janeiro de 1998, regulamenta a referida lei.

Em relação à Agência Nacional do Petróleo (ANP), ela foi criada como uma entidade integrante da Administração Federal indireta, submetida ao regime autárquico especial, como órgão regulador da indústria do petróleo, vinculado ao Ministério das Minas e Energia.

Dentre as atribuições da ANP estão a de fiscalizar o adequado funcionamento do Sistema Nacional de Estoques de Combustíveis e o cumprimento do Plano Anual de Estoques Estratégicos de Combustíveis (conforme o artigo $4^{\circ}$ da lei $\mathrm{n}^{0} 8.176$, de fevereiro de 1991).

Além disso, a ANP ficou encarregada de regular e autorizar as atividades relacionadas ao abastecimento nacional de combustíveis, fiscalizando-os diretamente ou através de convênios com outros órgãos da União, Estados, Distrito Federal ou Municípios. A partir de sua criação, a ANP assumiu as atividades do Departamento Nacional de Combustíveis (DNC), que foi extinto com a implantação da agência, no tocante as atividades de distribuição e revenda de derivados de petróleo e álcool combustível. 
A fim de tornar o mercado de distribuição mais competitivo e modificar a estrutura oligopolizada existente, o governo promoveu a abertura deste mercado a partir de 1995, surgindo inúmeras novas distribuidoras médias e pequenas. No início da década havia apenas oito distribuidoras, que controlavam a venda de aproximadamente 11 bilhões de litros de combustíveis. Em setembro de 1999 o número de distribuidoras existentes registradas na ANP era 169, que disputam um mercado de 23 bilhões de litros.

Além do Sindicom ${ }^{30}$, que detém praticamente $85 \%$ do mercado de distribuição, a partir da abertura do mercado de distribuição foi criado outro sindicato, o Sindicato das Distribuidoras Regionais de Combustíveis (Brasilcom), que em agosto de 1999 contava com 21 afiliadas em 8 estados (SP, RJ, ES, PR, SC, RS, MA e CE), e foram responsáveis por aproximadamente $7 \%$ dos combustíveis comercializados no País.

Atualmente os principais derivados de petróleo são comprados nas refinarias através de um sistema de cotas ou contratos, a preços tabelados, com exceção para o álcool anidro e hidratado, que são adquiridos diretamente dos produtores, em regime de preços liberados. A distribuidora é responsável pela mistura do álcool anidro à gasolina A (resultando a gasolina $\mathrm{C}$ ). $\mathrm{O}$ transporte dos produtos e estocagem concentram-se nas bases de distribuição, dispersas em 84 municípios.

Desta forma, a ANP tem sobre sua responsabilidade a fiscalização de 13 refinarias, 19 terminais marítimos, 20 terminais terrestres, 100 bases de distribuição, 169 distribuidoras, e 25.680 postos de combustíveis ${ }^{31}$

Dos principais problemas atualmente existentes no setor de combustíveis destacam-se a sonegação fiscal (relativos ao recolhimento de ICMS, PIS/COFINS e PPE), e a adulteração na qualidade da gasolina (seja por um teor de mistura com álcool mais elevado do que o permitido por lei, seja pela adição de solventes químicos).

Os efeitos da sonegação fiscal são sentidos pelo governo (devido a perda da arrecadação federal e estadual) e pelas distribuidoras e revendedores, que sofrem a

\footnotetext{
${ }^{30}$ Atualmente as seguintes distribuidoras fazem parte do Sindicom: Castrol, Cia São Paulo, DPPI, Esso, Ipê, Ipiranga, Mobil, Br-Petrobrás Distribuidora, Shell, Sabbá, Texaco, Tutela e Wal, conforme o site: http://www.Sindicom.br.

${ }^{31}$ Conforme o site: www anp.gov.br.
} 
concorrência desleal. É importante salientar que o setor de combustíveis no Brasil movimenta cerca de $\mathrm{R} \$ 50$ bilhões de reais por ano, gerando um potencial de arrecadação de impostos da ordem de $\mathrm{R} \$ 20$ bilhões de reais.

Por sua vez, a adulteração de combustíveis acarreta problemas nos motores dos carros dos consumidores e o aumento de poluição nas cidades.

Em relação as atribuições da ANP, é interessante notar que o artigo $10^{\circ}$ da Lei $N^{0} 9.478$ responsabiliza a agência pela comunicação ao Conselho Administrativo de Defesa Econômica (CADE), de fatos de seu conhecimento que configurem ou possam configurar infração da ordem econômica.

\subsubsection{A criação da Associação dos Municípios Canavieiros do Estado de São Paulo} (AMCESP)

Outra mudança do ambiente organizacional do setor sucroalcooleiro foi a criação, em novembro de 1997, da Associação dos Municípios Canavieiros do Estado de São Paulo (AMCESP), pelos prefeitos dos municípios canavieiros do Estado de São Paulo, com o apoio dos fornecedores e produtores de açúcar e álcool. A Associação representa os 220 municípios paulistas, envolvendo 11.000 plantadores de cana cadastrados, mais de 500 mil trabalhadores e 132 usinas e destilarias.

Os objetivos da AMCESP incluem atividades referentes ao desenvolvimento da agricultura canavieira, apoio e incentivo à educação ambiental e ao aprimoramento de tecnologias que privilegiem o álcool como fonte de combustível renovável. Pretende-se que a AMCESP seja um braço político dos municípios canavieiros, de forma a orientar as estratégias e ter uma ação coordenada dos municípios nas reivindicações junto aos Governos Federal e Estadual, e que seja um órgão de pressão na Assembléia Legislativa .

$\mathrm{Na}$ época de sua criação as primeiras ações pretendidas pela AMCESP eram no sentido de : (a) pressionar a aprovação do projeto de lei, na Câmara Federal, que permite a adição do álcool no diesel; (b) lutar pelo apoio à Frota Verde na Assembléia Legislativa de São Paulo; (c) alteração de lei estadual que desde 1991 repassou para os 
municípios distribuidores de álcool $50 \%$ do ICMS que antes ficavam com as cidades produtoras de cana. ${ }^{32}$

\subsubsection{A criação da Câmara Paulista do Setor Sucroalcooleiro}

Em dezembro de 1995 foi instituída a Câmara Paulista do Setor Sucroalcooleiro, como parte do Programa de Desenvolvimento e Competitividade do Estado de São Paulo, com o objetivo de se discutir as questões econômicas, ambientais e sociais relativas a este setor, influenciando sua eficiência e competitividade como um todo.

É interessante notar que as discussões que resultaram no "Pacto pelo Emprego no Agronegócio Sucroalcooleiro", firmado em São Paulo, originaram-se na Câmara Paulista do Setor Sucroalcooleiro.

\subsection{As mudanças no ambiente organizacional privado}

\subsubsection{A criação da UNICA}

Uma alteração importante ocorrida no ambiente organizacional das empresas no Estado de São Paulo, decorrente da desregulamentação, foi a criação, em abril de 1997, de uma nova entidade de produtores, denominada União da Agroindústria Canavieira de São Paulo (UNICA), que substituiu a Associação das Indústrias de Açúcar e Álcool do Estado de São Paulo (AIAA).

A UNICA foi criada com o objetivo de fortalecer a representação dos produtores e unificar as ações diante da nova realidade, agregando os interesses comuns das seguintes entidades: (i) Cooperativa dos Produtores de Açúcar e Álcool do Estado de São Paulo (COPERSUCAR), (ii) Associação da Indústria Sucroalcooleira do Estado de São Paulo (SUCRESP), (iii) Sociedade dos Produtores de Açúcar e Álcool do Estado de São Paulo (SOPRAL), (iv) Associação das Destilarias Autônomas, (ADA); (v) Sindicato da Indústria do Açúcar do Estado de São Paulo (SIAESP), (vi) o Sindicato da Indústria de Fabricação de Álcool do Estado de São Paulo (SIFAESP), (vii) Cooperativa dos

\footnotetext{
${ }^{32}$ Jornal da Cana, p.50, novembro de 1997.
} 
Produtores de Álcool e de Aguardente do Estado de São Paulo (COPACESP), e, (viii) União das Destilarias do Oeste Paulista (UDOP).

Das 133 unidades industriais existentes no Estado de São Paulo, na época 121 se afiliaram à UNICA. Em relação à produção brasileira, a UNICA produzia então aproximadamente $58 \%$ da produção de cana-de-açúcar; 58\% de açúcar; e, $60 \%$ da quantidade total brasileira produzida de álcool.

Em relação a agroindústria canavieira do Estado de São Paulo, os produtores da UNICA são responsáveis por $62 \%$ da cana, $67 \%$ do açúcar e $60 \%$ do álcool produzidos. Juntamente com a UNICA funcionam ainda, dirigidos pelo mesmo Conselho Diretor, o Sindicato da Industriado Açúcar no Estado de São Paulo - SIAESP e o Sindicato da Indústria da Fabricação do Álcool no Estado de São Paulo - SIFAESP que reúnem a totalidade das 133 unidades industriais do estado ${ }^{33}$.

\subsubsection{A fundação da CEPAAL}

Buscando também uma maior união dos produtores, procurando consolidar os interesses dos diversos estados produtores ${ }^{34}$, de modo a conciliar os interesses e lidar com o no novo ambiente desregulamentado, foi criada a Coligação das Entidades Produtoras de Açúcar e Álcool (CEPAAL).

A CEPAAL ${ }^{35}$ agrega um número significativo de Associações, Cooperativas e Sindicatos de Indústrias de Açúcar e Álcool dos Estados de São Paulo, Paraná, Mato Grosso, Mato Grosso do Sul, Goiás, Rio de Janeiro, Espírito Santo, procurando uma proposta única do setor para conviver com o sistema de livre mercado, representando 41 unidades produtivas, que são responsáveis por $58 \%$ da produção da região Centro-Sul ${ }^{36}$.

Em março de 1999 faziam parte da CEPAAL as seguintes entidades: (i) Associação das Destilarias Autônomas e Anexas (ADA); (ii) Associação dos Produtores

\footnotetext{
${ }^{33}$ Conforme o site: www.unica.com.br.

${ }^{34}$ Deve ser lembrado que da UNICA fazem parte somente os produtores e entidades do Estado de São Paulo.

${ }^{35}$ Conforme entrevista com Dr. Paulo A. Zanette, Presidente da Associação dos Produtores de Álcool e Açúcar do Paraná (ALCOPAR).

${ }^{36}$ Segundo KYTAIAMA, H. (Superintendente da SOPRAL). Comunicação Pessoal, março de 1999.
} 
de Álcool e Açúcar do Estado do Paraná (ALCOPAR), (iii) Cooperativa dos Produtores de Aguardente de Cana e Álcool do Estado de São Paulo (COPACESP); (iv) Sociedade das Usinas e Destilarias do Espírito Santo (SUDES); (v) Sindicato da Indústria Fabricação do Álcool do Estado de Mato Grosso do Sul (SINDMS); (vi) Sindicato da Indústria de Fabricação de Álcool do Estado de Mato Grosso (SINDMT), (vii) Sindicato da Indústria de Fabricação de Álcool do Estado de Goiás (SIFAEG), (viii) Independentes de São Paulo (TL); e, (ix) Sociedade de Produtores de Açúcar e Álcool (SOPRAL).

A maior parte dos associados da CEPAAL são as unidades oriundas do Proálcool, que na fase inicial montaram suas destilarias para produzir álcool hidratado. Com o encolhimento do Programa do Álcool, e com a tendência verificada há uns anos atrás de maior ênfase ao álcool anidro por parte de algumas liderança do setor ${ }^{37}$, estas unidades resolveram se unir para incentivar o uso do álcool hidratado, de forma a garantir sua sobrevivência em ambiente de livre mercado.

Portanto, o entendimento da CEPAAL é que o álcool hidratado deve ser considerado o principal produto a ser incentivado, e o álcool anidro funcionaria como um "colchão regulador" de forma a equilibrar o mercado de álcool hidratado, já que a proporção de anidro misturado na gasolina pode variar entre zero e $26 \%$. Ou seja, na falta de álcool hidratado, a proporção de álcool anidro na mistura seria reduzida, e a produção deste produto seria convertida em hidratado de modo a atender sua demanda; quando houvesse excesso de álcool hidratado o procedimento seria o inverso.

\subsubsection{A criação da Brasil Álcool S/A}

Mais uma alteração no ambiente organizacional das empresas do setor aconteceu em janeiro de 1999, quando foi anunciada a criação, na região Centro-Sul, da Brasil Álcool S/A, uma empresa formada com a finalidade de retirar do mercado cerca de 1,2 bilhões de litros de álcool, correspondentes ao excedente do produto existente. A

\footnotetext{
${ }^{37}$ Conforme verificado nas entrevistas realizadas neste trabalho, atualmente são poucos os que ainda acreditam somente na anidração do Programa.
} 
empresa foi formalizada em 23 de fevereiro de 1999, durante assembléia realizada em São Paulo, e tem a duração de funcionamento prevista para três anos.

Conforme João Carlos Figueiredo Ferraz ${ }^{38}$, um dos organizadores da nova empresa, dos 250 produtores da região Centro-Sul duzentos aderiram à nova empresa, integralizando 1,3 bilhões de litros de álcool, no valor de $\mathrm{R} \$ 0,25$ reais por litro, perfazendo um capital total de $\mathrm{R} \$ 325$ milhões de reais.

Dentre os grupos que aderiam a nova empresa, estão a COPERSUCAR, COSAN (da região de Piracicaba), Crystalsev (que reúne 7 usinas de Ribeirão Preto) e produtores da região de Assis, Araçatuba e dos Estados do Paraná, Minas Gerais, Mato Grosso, Mato Grosso do Sul e Goiás, que juntos representam $85 \%$ da produção de álcool da região Centro-Sul.

Conforme os estatutos da Brasil Álcool, ela é uma empresa criada com finalidade específica de exportação de álcool, como forma de garantir que o estoque retirado para enxugar o mercado não retornarão. Porém existe uma cláusula no estatuto da empresa que possibilita a venda deste álcool no mercado interno, em caso de falta do produto.

Desta forma, a Brasil Álcool além de promover as exportações do produto, pode funcionar como um fundo privado regulador de mercado, sendo os estoques administrados de forma a equilibrá-lo.

Na época da criação da empresa a expectativa formada é que, além da recuperação dos preços, houvesse uma reorganização do mercado, evitando discrepância de preços e concorrência predatória não só entre os produtores, como também entre as distribuidoras de combustíveis, que enfrentam a concorrência danosa entre elas, após a liberação do mercado de distribuição.

38 "Brasil Álcool S.A. tem capital de R\$325 milhões". Gazeta Mercantil, p.B-23, 23/02/99. 
Com o volume de álcool retirado do mercado ${ }^{39}$, mais as compras do produto anunciadas pelo governo, a empresa esperava retirar volume próximo aos excedentes do produto, saneando o mercado, com conseqüente recuperação nos preços.

Porém, o comportamento de preços não foi o esperado: embora durante a criação da Brasil Álcool tenha havido uma recuperação dos preços (entre janeiro e fevereiro de 1999), após sua oficialização os preços caíram aos menores níveis até então praticados. Ou seja, as expectativas formadas em torno da organização e funcionamento da Brasil Álcool fizeram que o mercado apresentasse uma reação que não foi confirmada após a sua oficialização.

Conforme Ferraz ${ }^{40}$, embora não tenha sido percebido na época da criação da empresa, para a recuperação dos preços do álcool, não era suficiente somente retirar o estoque excedente do produto, mas também deveria haver uma administração da sua oferta, que é feita em 6 meses para ser vendida ao longo do ano.

Ou seja, sem um controle sobre a oferta, na época da safra as questões referentes aos recursos necessários para a estocagem do produto, e para a própria produção (que são maiores nesta época) induzem os produtores a desovar sua produção em quantidades maiores que o mercado necessita, derrubando os preços.

Com a liberação do mercado e o fím da mesa de comercialização do governo, os produtores passaram a vender diretamente ao mercado, e em quantidades proporcionais às suas necessidades de caixa (que eram importantes porque os excedentes existentes pressionaram os preços dos produtos para baixo, reduzindo a receita do setor).

Ao se perceber a necessidade de administrar a oferta ao longo do ano (o que anteriormente era feito pelo governo, através da sua mesa de comercialização, que fazia com que os produtores retivessem seus estoques ${ }^{41}$ ), os produtores resolveram criar um

\footnotetext{
${ }^{39}$ O estoque de álcool excedente de cada unidade que foi usado na formação da empresa ficará em tanques lacrados nas próprias usinas. Uma empresa contratada lacrará os tanques das usinas, sendo verificado periodicamente o volume e qualidade do produto estocado. Cada usina, junto com a empresa contratada, será fiel depositária do álcool.

${ }^{40}$ FERRAZ, J.C.F. (Presidente da Bolsa Brasileira de Álcool). Comunicação Pessoal, Outubro de 1999.

${ }^{41}$ Conforme analisado na seção 4.7 , as compras do governo eram feitas com base na velocidade de comercialização de cada produtor, a qual, embora apresentasse distorções, amenizava este problema.
} 
sistema de comercialização conjunta da produção de álcool, nascendo a Bolsa Brasileira de Álcool (BBA).

\subsubsection{A fundação da Bolsa Brasileira de Álcool (BBA)}

Em 22 de maio de 1999 aconteceu mais uma modificação importante no ambiente organizaçional das empresas, que foi a criação da Bolsa Brasileira de Álcool (BBA), com o objetivo de reorganizar a comercialização de álcool no Brasil, e que tem a duração prevista de um ano, com possibilidade de prorrogação para dois.

Fazem parte da BBA aproximadamente 170 produtores da região Centro-Sul (com exceção do Rio de Janeiro), responsáveis por $78 \%$ da produção de álcool da referida região, cuja produção será comercializada com as distribuidoras exclusivamente pela BBA.

Desta forma, a BBA funciona como um "pool" de comercialização, cujo objetivo principal é ordenar a oferta de álcool ao longo do ano, para proporcionar uma maior estabilidade de preços para o produtor, dado o desequilíbrio entre a produção e demanda existente.

Segundo Ferraz ${ }^{42}$ a Bolsa Brasileira de Álcool funciona como uma corretora, de propriedade dos produtores, na qual não existe expectativa de lucros. Os sócios assinam um contrato de adesão, no qual se comprometem a vender toda sua produção através da BBA, existindo um sistema de punição ${ }^{43}$ para os associados que comercializarem seus produtos fora das normas estabelecidas nos contratos de adesão.

É interessante notar que a proposta jurídica de criação da empresa foi submetida ao Conselho Administrativo de Defesa Econômica (CADE), já que a criação da BBA implica em concentrar $78 \%$ da produção de álcool numa só empresa.

O processo está sendo julgado pelo CADE, que não impediu a criação e funcionamento da BBA até que ele seja concluído, o que inclusive permite a avaliação da conduta da nova empresa durante o período de análise do processo.

\footnotetext{
${ }^{42}$ Ferraz, J.C.F. (Presidente da Bolsa Brasileira de Álcool). Comunicação Pessoal, Outubro de 1999.

${ }^{43}$ Cada associado assinou notas promissórias no valor de todo o volume projetado de sua produção, ao preço de $\mathrm{R} \$ 0,50$ centavos por litro, que podem ser descontadas no caso de venda fora da BBA.
} 
Além disso, Ferraz ${ }^{44}$ citou que tanto a Brasil Álcool como a BBA são instrumentos privados importantes para assegurar a sustentação e tranqüilidade de abastecimento, dada a retomada do uso do produto. A Brasil Álcool pode ser usada como estoque regulador do mercado interno, em caso de necessidade de produto, podendo inclusive promover importações do mesmo. Para isso, contudo, existe a necessidade de recursos para financiar os estoques, que podem vir de três fontes: de uma operação de warrantagem $^{45}$, da securitização dos recebíveis (correspondendo a um adiantamento aos produtores que já tivessem contratos com as distribuidoras para os próximos meses), e de recursos de exportações (que seriam usados para comprar os estoques dos produtores).

\subsection{As alterações decorrentes da desregulamentação nos suportes ao álcool combustível, à cana-de-açúcar e ao frete das regiões distantes}

\subsubsection{O suporte ao álcool}

O álcool hidratado atualmente não compete com a gasolina em termos estritamente econômicos, já que seu custo de produção é maior que o deste produto. Para tornar seu uso viável, existe um mecanismo de complementação de preços ao produtor, cujos recursos vêm da cobrança de um sobre-preço nos preços dos combustíveis derivados de petróleo (inclusive o diesel, que movimenta a maior parte da carga do País e quase todo o transporte urbano coletivo).

Estes recursos são destinados a uma conta da PETROBRAS, atualmente chamada de Parcela de Preço Específica (PPE), que inicialmente era chamada Conta Álcool, sendo depois denominada de Fundo de Uniformização de Preços (FUP). Os recursos da conta FUP eram repassados ao Fundo de Unificação dos Preços do Álcool (FUPA), e eram usados para tornar o consumo do álcool viável frente à gasolina, e para unificar os preços do produto em qualquer ponto do País.

\footnotetext{
${ }^{44}$ FERRAZ, J.C.F. (Presidente da Bolsa Brasileira de Álcool). Comunicação Pessoal, Outubro de 1999.

${ }^{45}$ O CIMA disponibilizou em $1998 \mathrm{R} \$ 500$ milhões de reais para operações de warrantagem, dos quais ainda restam $\mathrm{R} \$ 300$ milhōes de reais. A BBA está tentando que a ANP autorize o Banco do Brasil liberar estes recursos para que a BBA realize a operação.
} 
Os recursos da conta Parcela de Preço Específica (PPE) são usados para os diversos incentivos dados pelo Governo ao setor, dentre eles o suporte ao álcool hidratado, sendo que este apoio, inicialmente previsto para terminar em janeiro de 1997 (Portaria $\mathrm{N}^{\mathrm{0}} 114$, do Ministério das Minas e Energia), foi mantido até agosto de 2.000. A partir desta data, será necessário a criação de ouro mecanismo (provavelmente tributário) para viabilizar o uso do álcool hidratado como combustível.

Em fevereiro de 1999 foi emitida a Resolução do CIMA $N^{0}$ 10, que trata de diversos assuntos. Primeiramente reduziu o valor do suporte ao álcool hidratado (que assegura sua competitividade com a gasolina), que passou de $\mathrm{R} \$ 0,127$ reais por litro para $\mathrm{R} \$ 0,0450$ reais por litro, devendo este valor ser revisto no prazo de até quatro meses da implantação do sistema.

Embora a redução do valor do suporte tenha sido motivo de muito descontentamento entre os produtores, ele obedece, conforme Serodio ${ }^{46}$, a uma lógica de preços que objetiva garantir a competitividade entre o álcool hidratado e a gasolina na bomba.

Para ser considerado atraente pelo consumidor, o preço do álcool deve ser $75 \%$ do preço da gasolina, já que seu consumo é maior devido ao menor rendimento deste combustível. Partindo de uma referência de custos de produção, e dado que os custos de produção do álcool são maiores que os da gasolina, ele não chegaria para o consumidor com esta diferença de preços que o torna atrativo.

Desta forma, existe o suporte dado pelo governo, que é calculado em função do preço da gasolina e do preço do álcool (então) tabelado pelo governo, de forma a garantir sua competitividade. $O$ valor anteriormente estipulado ( $\mathrm{R} \$ 0,127$ reais por litro) foi estimado da seguinte forma: quando o preço da gasolina fixado pelo governo na refinaria era de $\mathrm{R} \$ 0,38$ reais por litro (até agosto de 2.000 o preço da gasolina na refinaria ainda será fixado pelo governo, atualmente ele é livre somente na bomba), o preço máximo que as distribuidoras poderiam pagar pelo álcool (de forma a ter um produto competitivo

\footnotetext{
${ }^{46}$ SERODIO, E. (Diretora do Departamento de Álcool e Açúcar do MDIC). Comunicação Pessoal, Abril de 1999.
} 
na bomba em relaçăo à gasolina), era $\mathrm{R} \$ 0,2864$ reais por litro (que representa $75 \%$ de $\mathrm{R} \$ 0,38)$.

Como o preço do álcool estava tabelado pelo governo em $\mathrm{R} \$ 0,4134$ reais, o valor do suporte era de $\mathrm{R} \$ 0,127$ reais por litro. Ou seja, a distribuidora pagava $\mathrm{R} \$ 0,2864$ por litro, o governo complementava com $\mathrm{R} \$ 0,127$ por litro, de forma que o produtor acabava recebendo o preço tabelado.

Em dezembro de 1998, houve um aumento de preço da gasolina, devido a aplicação diferenciada de impostos sobre este derivado do petróleo. O preço da gasolina na refinaria subiu aproximadamente $10 \%$, passando a $R \$ 0,4180$ por litro. Desta forma, o preço que as destilarias poderiam pagar pelo álcool também aumentou, passando para $\mathrm{R} \$ 0,3150$ (ou seja, $75 \%$ de $\mathrm{R} \$ 0,4180$ ). Como em dezembro o preço do álcool ainda estava tabelado em $\mathrm{R} \$ 0,4134$ por litro, o subsídio poderia se reduzir para $\mathrm{R} \$ 0,0984^{47}$. Note que se os preços da gasolina subirem o suficiente, este suporte pode desaparecer.

Esta é a lógica do cálculo do suporte feito pelo governo. Mas, conforme salientado por Seródio ${ }^{48}$, já nesta época (dezembro de 1998), a despeito do tabelamento de preços do álcool ainda estar vigorando, os preços que os produtores estavam recebendo, devido a super-oferta existente, eram bastante inferiores (chegando a receber das distribuidoras $R \$ 0,1816$ por litro de álcool ao invés dos $R \$ 0,3150$, que era o preço que elas poderiam pagar para manter o produto competitivo com a gasolina na bomba).

Dado o excesso de álcool existente no mercado, a percepção do governo foi que a única ação a ser tomada que poderia melhorar os preços aviltados que os produtores estavam recebendo era reduzir a oferta de álcool existente, ou seja, sanear o mercado. Como os recursos disponíveis a serem gastos pelo Programa estavam fixados (em $\mathrm{R} \$ 1,1$ bilhões de reais no ano de 1999, conforme a Resolução do CIMA № 6), a decisão governamental foi no sentido de realocar parte dos recursos destinados ao suporte de preços para a compra dos estoques excedentes.

\footnotetext{
${ }^{47}$ Este valor não chegou a ser praticado, serve como exemplo da lógica do suporte.

${ }^{48}$ Serodio, E. (Diretora do Departamento de Álcool e Açúcar do MDIC). Comunicação Pessoal, Abril de 1999.
} 
O preço de mercado a vigorar após o enxugamento foi estimado em $\mathrm{R} \$ 0,36$, e, dado que o preço que as distribuidoras podiam pagar era $\mathrm{R} \$ 0,3150$, o suporte foi fixado em $\mathrm{R} \$ 0,045$. Deve ser salientado que esta decisão foi discutida no Conselho Consultivo do CIMA, e teve, portanto o aval dos produtores.

Além disso, a Resolução $\mathrm{N}^{\mathrm{o}} 10$ alterou o mecanismo de repasse do suporte, que passou a ser pago diretamente ao produtor de álcool, como forma de impedir que algumas distribuidoras se apropriassem de um recurso destinado aos produtores.

Antes desta resolução, as distribuidoras pagavam o álcool dos produtores ao preço tabelado pelo governo ( $\mathrm{R} \$ 0,41 / 1)$. A ANP repassava os recursos referentes ao suporte ( $\mathrm{R} \$ 0,127 / 1)$, da conta PPE para os Estados, que então isentava as distribuidoras do pagamento do ICMS referente. Porém, algumas distribuidoras não pagavam aos produtores a parte do suporte que thes era devida (de forma a totalizar o preço tabelado de $R \$ 0,41 / 1)$, e eles solicitaram que o pagamento fosse feito diretamente.

Atualmente o suporte dado pelo governo para garantir a competitividade entre álcool e hidratado e gasolina é garantido somente sobre o volume para o qual se tenha uma demanda efetiva (estimada pelo governo), e não sobre a produção total. O suporte é dado sobre o volume demandado em cada Estado, sendo o repasse aos produtores feito pelos Sindicatos das Indústrias de Fabricação de Álcool e Açúcar de cada Estado.

Conforme Serodio (1999) no ano de 1999 o governo garantirá o suporte de $\mathrm{R} \$ 0,045$ por litro de álcool hidratado sobre um volume total de 7,3 bilhões de litros (que é a demanda estimada), totalizando gastos da ordem de $\mathrm{R} \$ 330$ milhões de reais com o suporte a este produto.

\subsubsection{O suporte à cana-de-açúcar das regiões menos competitivas}

Conforme salientado anteriormente, desde 1971 existe um mecanismo de suporte à produção da cana-de-açúcar da Região Nordeste, visando a equalização de custos da cana de açúcar entre as duas regiões produtoras, já que os custos de produção desta Região maiores que os da Centro-Sul impediriam sua sobrevivência, especialmente em ambiente de livre mercado. 
A Resolução do CIMA № 5, de setembro de 1998, referiu-se ao montante destinado ao sistema de equalização de preços da cana-de-açúcar dos Estados da Região Nordeste (cujos recursos também originam-se da conta Parcela de Preço Específico), e apoiou-se na necessidade de medidas de apoio ao plantador de cana-de-açúcar do Nordeste, de modo a garantir o funcionamento da agroindústria canavieira regional, responsável por 350.000 empregos agrícolas.

Conforme a referida Resolução, o volume sujeito à equalização de preços foi fixado em 48,5 milhões de toneladas a cada ano-safra, sendo que a execução do programa de apoio ficou a cargo da Superintendência do Desenvolvimento do Nordeste (SUDENE). ${ }^{49}$

A Portaria do Ministério da Fazenda № 275, de outubro de 1998, estabeleceu o valor do suporte aos produtores de cana dos estados do Nordeste em $\mathrm{R} \$ 5,07$ reais por tonelada, a título de medida interna de apoio às lavouras canavieiras da região (cujos custos de produção são mais altos que os do Centro-Sul).

Em relação à equalização dos custos de produção da cana-de-açúcar, a Resolução № 10 do CIMA ampliou os Estados merecedores do suporte, autorizando a aplicação dos recursos nos Estados de Espírito Santo, Goiás, Mato Grosso, Mato Grosso do Sul, Minas Gerais, Pará, Rio de Janeiro e Tocantins. Conforme Serodio (1999) os gastos decorrentes desta medida de apoio no ano de 1999 são estimados em R\$190 milhões de reais.

\subsubsection{O suporte ao frete das regiões mais distantes dos centros de consumo}

Conforme a Resolução № 10 do CIMA os produtores de álcool de regiões remotas (Estados do Mato Grosso e Mato Grosso do Sul ) passaram a fazer jus a um apoio temporário, referente a um frete de transporte. O prazo deste apoio é estipulado em

\footnotetext{
${ }^{49}$ Para acompanhar e avaliar a execução deste programa de equalização de custos da cana de açúcar, foi constituído, através da Resolução do CIMA N ${ }^{9} 7$, de outubro de 1998, um Grupo Interministerial, com representantes da SUDENE, do MICT, do MINFAZ e da ANP.
} 
cinco anos ${ }^{50}$, sendo que os valores são decrescentes a partir do segundo ano, destinado a permitir a comercialização do produto destes Estados no mercado interno, em bases competitivas.

Segundo Serodio (1999) procurou-se dar oportunidade para que nestes cinco anos os produtores destas regiões buscassem novas alternativas, desenvolvessem novos mercados para comercializar seus produtos, já que até antes da liberação o próprio Estado não permitia que isto acontecesse. No primeiro ano (1999) os gastos com esta medida de apoio são estimados em $\mathrm{R} \$ 31$ milhões de reais, sendo decrescentes nos próximos anos, e terminando no ano 2003.

\subsection{As alterações sobre o controle da produção e comercialização: as cotas de produção e os Planos de Safra, as exportações, e a cobrança diferenciada do IPI do açúcar}

\subsubsection{As cotas de produção e os Planos de Safra}

Entre os anos de 1995 e 1996, diversas Medidas Provisórias emitidas referentes ao setor sucroalcooleiro foram no sentido de regulamentar o abastecimento de seus produtos no mercado. Conforme estas Medidas, os Planos de Safra continuavam a ser emitidos pelo Ministério da Indústria, do Comércio e do Turismo, visando o controle da produção de açúcar e álcool, sendo do MICT a responsabilidade de fixar os volumes de produção de açúcar e de álcool necessários ao abastecimento dos mercados na região Centro-Sul e na região Norte-Nordeste, bem como dos destinados à formação de estoques de segurança.

As necessidades de importação de produtos necessários para completar a oferta nacional também seriam fixadas pelo referido Ministério nos Planos de Safra, sendo que no caso do álcool as decisões eram tomadas conjuntamente com o DNC.

Não obstante a sinalização do governo fosse no sentido de liberação do setor, o que levava uma parte dos agentes a se mover nesta direção, é interessante notar que até a

\footnotetext{
${ }^{50}$ Estipulado em função do tempo necessário para que os investimentos feitos na lavoura de cana-deaçúcar tenham sido recuperados.
} 
safra de 1996/97, a despeito do processo de desregulamentação já iniciado, o setor sucroalcooleiro ainda era fortemente regulamentado, no que se referia à produção e comercialização de açúcar e álcool.

Os preços da tonelada de cana-de-açúcar, do açúcar cristal standard, do álcool hidratado (para fins carburantes ou industriais) e do mel residual, bem como os tributos incidentes sobre a matéria-prima, para cada região, foram estipulados pela Portaria $\mathrm{N}^{\mathrm{o}}$ 110, do Ministério da Fazenda, de maio de 1997.

Até a safra 1997/98 ainda foi publicado o Plano de Safra (Portaria № 46, de abril de 1997, do MICT), no qual foram estabelecidas as cotas de açúcar e álcool destinadas a cada grande região produtora (Norte-Nordeste e Centro-Sul), bem como dos excedentes exportáveis sujeitos à isenção tarifária (as alíquotas do imposto sobre exportação foram zeradas em maio de 1997, através de despacho conjunto do MICT e do Ministério da Fazenda).

Conforme Carvalho ${ }^{51}$, este Plano de Safra foi totalmente desvinculado da realidade de mercado, permitindo importações desnecessárias de álcool etílico (privadas) e de metanol (pela PETROBRÁS), levando aos elevados níveis de excedentes que acabaram por criar uma das maiores crises já vividas pelo setor sucroalcooleiro, evidenciando a dificuldade do governo de continuar intervindo no setor.

\section{- A Medida Provisória № 1.670 (junho de 1998)}

Em junho de 1998, em pleno processo de desregulamentação, foi editada a Medida Provisória № 1.670 , regulamentada posteriormente por Decreto do Presidente, estabelecendo as regras para a fiscalização das atividades relativas ao abastecimento nacional de combustíveis, e também fixando as sanções administrativas para diversas infrações. A Agência Nacional do Petróleo (ANP) ficou encarregada da fiscalização das atividades relativas à indústria do petróleo e ao abastecimento nacional de combustíveis (de que trata a Lei № 9.748, de agosto de 1997).

\footnotetext{
${ }^{51}$ CARVALHO, L.C.C. (Membro Câmara Técnica do CIMA, Superintendente da União da Agroindústria Canavieira de São Paulo - UNICA), Comunicação Pessoal, Outubro/1998.
} 
Especificamente em relação ao álcool combustível, é importante notar que a referida Medida Provisória conferiu ao Poder Executivo autoridade para fixar preços e estabelecer cotas ou volumes de produção e comercialização de álcool etílico combustível e de sua matéria-prima, tal qual era feito pelo IAA, extinto há quase dez anos.

Previa também que o Poder Executivo poderia instituir comitê destinado a promover a alocação mensal, em unidades produtoras, de pedidos de aquisição de álcool etílico combustível formulados por companhias distribuidoras de combustíveis líquidos.

Segundo Coral (1998), a referida Medida significou um retrocesso para o setor, salientando que $60 \%$ dos canaviais são destinados à produção de álcool, estando portanto o preço da cana sujeito ao tabelamento do governo, e $40 \%$ são para fabricação de açúcar, ou seja, o fornecedor iria receber um preço pela tonelada da cana, livre ou tabelado, em função do tipo de produto fabricado pela unidade industrial.

Esta opinião também é compartilhada pelo presidente do grupo $\operatorname{COSAN}^{52}$, que considerou a medida ineficaz, salientando que o governo não teria condições de fiscalizar a produção e comercialização do álcool, o que foi confirmado pelo próprio assessor da diretoria da ANP, Paulo Lima ${ }^{53}$.

\subsubsection{As exportações de açúcar}

Quanto às exportações, as Medidas Provisórias emitidas nesta época estabeleciam que nos Planos de Safra seriam fixados os excedentes às necessidades dos mercados internos regionais que poderiam ser exportados, bem como as cotas destinadas à exportação atribuídas a cada unidade produtora. Sobre as exportações incidia um imposto (Imposto de Exportação), cuja alíquota de $25 \%$ poderia ser reduzida ou aumentada pelo Poder Executivo, mediante ato do Conselho Monetário Nacional.

Também é estabelecido que as exportações podem ter isenção total ou parcial do referido imposto, mediante despacho conjunto dos Ministros da Fazenda e da

\footnotetext{
${ }^{52}$ Formado por sete usinas na região de Piracicaba (SP).

53 "Mercado de álcool volta a ser controlado pelo governo". Gazeta Mercantil, Caderno Agribusiness, C-7, p. 26,27 e 28/06/1998).
} 
Indústria, do Comércio e do Turismo, sendo que as exportações de açúcar e álcool com isenção do imposto eram objeto de cotas atribuídas às empresas produtoras nos Planos Anuais de Safra, ou de ofertas públicas, regionais e periódicas.

Além disso, ficavam isentas do Imposto de Exportação as seguintes operações: as amparadas em autorização de produção de açúcar para o mercado externo, concedidas a empresas localizadas na região Norte-Nordeste pelo extinto Ministério da Integração Regional, e com embarques previstos até 31 de agosto de 1995; as exportações de açúcar destinadas ao mercado preferencial norte-americano, nos volumes previamente autorizados, com embarques até 30 de setembro de 1995; e, as exportações de açúcar previamente autorizadas, vinculadas a operações de importação de álcool já realizadas.

Deve ser notado que embora tivesse um discurso liberal, o Governo Federal, através do MICT, procurava manter o controle sobre o setor, e que ainda neste época as exportações da região Nordeste eram privilegiadas, já que seu excedente exportável ficava isento do imposto de exportação.

Porém, a fragilidade estrutural do Ministério da Indústria e do Comércio não permitia uma ação eficiente de planejamento do setor, e muito menos de fiscalização, evidenciando a dificuldade do Governo em manter o velho modelo de intervenção. Estes fatores dificultavam que o Governo encontrasse mecanismos de viabilizar a lógica da distribuição de quotas no tocante às exportações, levando o Governo Federal a impor as alíquotas de exportações.

Nesta época, os produtores do Centro-Sul, cuja produção mostrava um crescimento efetivo, com a criação de excedentes, já lutavam pela liberação das exportações, enquanto os do Nordeste (que apresentava um equilíbrio entre a oferta e a demanda) preferiam a manutenção do sistema de cotas de exportação. Diversas medidas judicias impetradas pelos produtores do Centro-Sul, apoiados na Constituição Federal de 1988, já pesavam na ocasião contra o Governo Federal.

Apesar das reivindicações dos produtores do Centro-Sul no tocante às exportações, a Medida Provisória № 1.476-15, de setembro de 1996, continuava a privilegiar as exportações da Região Norte-Nordeste, já que reafirmava o anteriormente 
estabelecido pela Lei № 4870 (de dezembro de 1965), que os volumes de produtos derivados de cana-de-açúcar destinados aos mercados preferenciais eram atribuídos à referida região, tendo em conta seu estágio de desenvolvimento sócio-econômico. Em dezembro de 1996 esta Medida provisória foi convertida na Lei № 9.362.

A posição do Governo Federal nesta época não era das mais confortáveis, já que, além de não, ter estrutura suficiente para impor seu controle sobre o setor sucroalcooleiro, suas ações eram no sentido oposto ao estabelecido pela Constituição Federal de 1988, o que o expunha às medidas judiciais e às contestações dos produtores da região Centro-Sul, que naquele momento já respondiam por $85 \%$ da produção de cana industrial do País.

Finalmente em maio de 1997, através de Despacho Interministerial do MICT e do MINFAZ, foi zerada a alíquota do imposto de exportação sobre o açúcar, alterando portanto o sistema de cotas de exportação sujeitas à isenção tarifária (estabelecidas, para a Safra de 1997/98 pela Portaria № 46, de abril de 1997). Esta medida, além de aumentar as receitas oriundas das exportações, melhorando o saldo da balança comercial, era esperada há muito tempo, já que o antigo sistema de cotas de exportações isentas de imposto prejudicava as empresas mais competitivas.

Deve ser notado que a alíquota do imposto de exportação sobre o açúcar brasileiro foi zerada, mas a mesma continua a existir, ou seja, o governo pode alterá-la (até o limite de $40 \%$ ) conforme suas necessidades (por exemplo garantir o abastecimento do mercado doméstico de açúcar ou direcionar a produção do açúcar de exportação para álcool, para garantir o abastecimento).

\subsubsection{A cobrança diferenciada do Imposto sobre Produto Industrializado (IPI) sobre o açúcar de cana}

Outra política do governo que também foi motivo de diversas liminares impetradas pelos usineiros do Centro-Sul contra o Governo foi a política nacional de preços unificados do açúcar. Visando equalizar o preço entre as duas regiões (já que as usinas do Centro-Sul, por serem mais competitivas, têm custos menores), foi imposta a 
cobrança do Imposto sobre Produto Industrializado (IPI) sobre o açúcar de cana, a partir de 1992.

Através do Decreto № 420 , de janeiro de 1992, passou-se a tributar as saídas de açúcar de cana promovidas pelas refinarias (com exceção do tipo amorfo), com alíquotas diferenciadas conforme a região: enquanto para a região Centro-Sul esta alíquota era de $18 \%$ e para o Rio de Janeiro e Espírito Santo era de 9\%, para os estabelecimentos industriais situados nas áreas de atuação da SUDENE e SUDAM a alíquota era de 0\%, ou seja, estavam isentos do recolhimento do tributo.

Diversas contestações judiciais foram impetradas pelos usineiros do Centro-Sul, os quais ou não pagaram o IPI ou depositaram seu valor em juízo. Em 1995, conforme a Portaria do Ministério da Fazenda $\mathrm{N}^{\mathrm{0}} 189$, as alíquotas continuavam mantidas, mas alterou-se o tipo de açúcar sobre a qual elas incidiam, sendo que a partir de então o único produto a ser submetido à política de preços unificados ficou sendo o açúcar cristal standard.

Até novembro de 1997, estas eram as alíquotas que vigoravam, sendo que a cobrança do IPI, e este sistema de alíquotas diferenciadas ainda eram rnotivos de freqüentes contestações judiciais dos usineiros do Centro-Sul, que continuavam sem recolher o tributo ou o recolhendo-o em juízo.

Em novembro de 1997, através da Portaria №1602, estabeleceu-se fixação da alíquota única de $12 \%$ para todas as regiões produtoras. Porém, o Decreto № 2501 , de fevereiro de 1998, "a fim de tornar mais equilibrado o peso da tributação entre as diferentes regiōes produtoras", especificou que, embora a alíquota de $12 \%$ fosse válida para todas as regiões, algumas regiões produtoras, cujos custo de produção são maiores, poderiam abater certa porcentagem sobre o valor do IPI a ser pago.

Conforme o referido Decreto, a região Norte-Nordeste poderia abater até $85 \%$ do IPI devido, resultando numa alíquota de $1,8 \%$. Para os produtores do Rio de Janeiro e Espírito Santo o desconto poderia ser de $30 \%$, implicando numa alíquota de $8,4 \%$, sendo que os outros estados da região Centro-Sul não teriam desconto nenhum. As brigas judiciais continuaram e, na prática, o que se verificou é que a grande maioria dos 
produtores não recolheu ou recolheu o IPI em juízo, sendo que os poucos recolhimentos foram sobre as vendas feitas para as indústrias de refrigerantes.

\subsection{As mudanças na comercialização da cana-de-açúcar decorrentes da desregulamentação do setor}

A mudança no ambiente institucional iniciada pela Portaria № 94 e posteriormente complementada pela Portaria $\mathrm{N}^{\mathrm{0}}$ 294, causou também bastante preocupação entre os fornecedores de cana e as unidades industriais produtoras de açúcar e álcool, que até então comercializavam a cana-de-açúcar com bases em preços oficiais ditados pelo governo (através da Secretaria de Desenvolvimento Regional).

A liberação dos preços do álcool anidro, do álcool hidratado, e da cana-deaçúcar (prevista para maio de 1998), impunha a necessidade de uma nova forma de remuneração da cana-de-açúcar em substituição ao tabelamento de preços pelo governo anteriormente praticado, que atendesse tanto aos fornecedores de cana como às usinas e destilarias.

\subsubsection{O CONSECANA}

Constituiu-se no Estado de São Paulo um grupo técnico e econômico formado por cinco representantes dos produtores de cana, indicados pela Organização dos Plantadores de Cana do Estado de São Paulo (ORPLANA), e cinco dos industriais, indicados pela União da Agroindústria Canavieira de São Paulo (UNICA), para desenvolver um novo modelo para a remuneração da cana-de-açúcar, o qual foi apresentado em 14 de abril de 1998, na sede da Bolsa de Mercadorias e Futuros (BM\&F), em São Paulo ${ }^{54}$.

Com o novo modelo, passaria a vigorar um mecanismo de auto-gestão, em substituição a antiga tutela governamental. Silva (1998) apresenta este novo modelo (ver Anexo B), que começaria a vigorar a partir de $1^{\circ}$ de maio de 1998 , salientando que a pureza do caldo e a Pol \% da cana continuam servindo de base para o pagamento, mas

\footnotetext{
54 "Muda sistema de negociar cana-de-açúcar". Gazeta Mercantil, 1ํo caderno, p.1, de 14/04/98.
} 
ao invés de serem usados para calcular o Teor de Sacarose da cana-de-açúcar, será utilizado para se calcular a quantidade de Açúcar Total Recuperável (ATR), que entra no cálculo do preço da tonelada de cana.

Resumidamente, neste modelo de pagamento o valor da tonelada da cana será determinado a partir da quantidade de ATR contidos na matéria-prima entregue pelo produtor, pela participação média da matéria-prima no ATR entregue (ponderada em função do mix de produção da indústria), e pelo valor do ATR, obtido em nível estadual (ponderada em função dos preços dos produtos fabricados pela usina, açúcar e/ou álcool, praticados nos mercados interno estadual e externo).

Os preços do açúcar e do álcool anidro e hidratado, no mercado doméstico e no mercado externo, são levantados pela Escola Superior de Agricultura "Luiz de Queiroz" (ESALQ), através do Centro de Estudos Avançados em Economia Aplicada (CEPEA) ${ }^{55}$.

Desta forma, oscilações ocorridas nos preços do álcool e do açúcar são repassadas ao preço da tonelada da cana-de-açúcar, indicando que, neste novo modelo, o produtor de cana participa mais das variações ocorridas nos mercados dos produtos finais.

O sistema como um todo será gerido pelo Conselho de Produtores de Cana, Açúcar e de Álcool de São Paulo (CONSECANA), que terá um Conselho Diretor e o apoio do Grupo Técnico e Econômico (GTEC), e o suporte da Câmara Técnica de Avaliação da Qualidade da Cana (CANATEC-SP). As possíveis desavenças serão arbitradas pela Câmara de Juízo Arbitral da Bolsa de Mercadorias e Futuros (BM\&F).

Embora este modelo tenha sido desenvolvido pela Comissão Técnica formada por representantes da ORPLANA e da UNICA, do Estado de São Paulo, a expectativa era que ele acabasse se estendendo para as outras regiões produtoras.

No Estado de São Paulo, com a liberação de preços prevista para $1^{0}$ de maio de 1998, parecia haver consenso entre fornecedores e industriais quanto à utilização do

\footnotetext{
${ }^{55}$ Originalmente os preços do açúcar do mercado externo foram coletados junto à Secretaria de Comércio Exterior (SECEX) e à Bolsa Londres.
} 
novo sistema de pagamento da cana-de-açúcar, mas o adiamento da liberação de preços para novembro de 1998 dividiu o setor.

Em junho de 1998, enquanto mais de 50\% dos fornecedores do Estado tinham aderido ao novo modelo ${ }^{56}$, os fornecedores de cana das regiões de Ribeirão Preto e Jaú não estavam entregando a cana nas usinas por acreditarem que teriam perdas com a adoção do mesmo.

Dentro das próprias Associações de Fornecedores de Cana nesta época as opiniões sobre o assunto eram divergentes, sendo que na safra 1998/99, no Estado de São Paulo, coexistiram as duas formas de pagamento para a cana-de-açúcar. Conforme Coral (1998), na referida safra, a adesão ao modelo de autogestão no Estado de São Paulo foi de $80 \%^{57}$, mesmo estando em desacordo com as medidas do governo, devido a ausência de Plano de Safra e de regulamentação relativos ao setor.

\subsection{As mudanças na comercialização do álcool combustível decorrentes da desregulamentação do setor}

\subsubsection{A mesa de comercialização do governo}

A forma de comercialização do álcool anidro e hidratado vem se alterando ao longo do tempo, podendo ser reconhecidas, conforme Rodrigues ${ }^{58}$, três fases distintas.

$\mathrm{Na}$ primeira delas, ainda com os preços dos combustíveis tabelados, a comercialização destes produtos era feita na Mesa de Comercialização governo, sendo baseada nos Planos de Safra do IAA. A legislação estabelecia que mensalmente o Departamento Nacional dos Combustíveis (DNC), em conjunto com o Sindicato das Distribuidoras de Combustíveis (SINDICOM) e com os Sindicatos dos Produtores de Álcool definiam as compras mensais do produto.

\footnotetext{
56 "Preço da cana gera protesto em São Paulo". Folha de São Paulo, Agrofolha, 16/06/1998.

${ }^{57}$ As associações de Jaú e da Barra Bonita, conforme Coral (1998), optaram pelo tabelamento.

58 RODRIGUES, P.A. (Membro da Câmara Técnica do CIMA; Departamento de Economia e Planejamento da UNICA), Comunicação pessoal, 1999.
} 
Os produtores vendiam sua produção em bases mensais (1/12), as distribuidoras compravam a quantidade que o mercado demandava, e se houvesse excedentes, estes eram comprados pela Petrobrás.

$\mathrm{Na}$ segunda fase, a comercialização ainda era feita integralmente na Mesa de Comercialização, mas as compras deixaram de serem feitas considerando-se os Planos de Safra, passando-se a trabalhar com a disponibilidade de álcool.

Neste caso, as usinas apresentavam um formulário com as respectivas disponibilidades mensais, e o SINDICOM (que nesta época era responsável por 100\% do abastecimento do mercado), apresentava os volumes de compra necessários, sendo que o mesmo era dividido entre os produtores baseado na disponibilidade de cada um. Não havia compra de excedentes, os mesmos eram de responsabilidade dos produtores.

Posteriormente, este sistema sofreu uma alteração, sendo que ao invés das compras serem baseadas na quantidade disponível de cada unidade produtora, elas passaram a ser feitas considerando a velocidade de produção de cada uma no decorrer da safra, o que gerava o direito de comercialização de cada produtor ${ }^{59}$.

Desta forma, o mercado era rateado em relação ao direito de comercialização de cada produtor. Este procedimento de comercialização era baseado num acordo setorial, assinado pelos Sindicatos, tendo funcionado nas últimas seis safras (de 93/94 a 98/99).

Nastari ${ }^{60}$ salienta que nesta sistemática de comercialização as informações prestadas pelos produtores para os planilhamentos mensais nem sempre eram confiáveis, o que acabava provocando algumas distorções. Os produtores que super dimensionavam suas produções acabavam tendo um direito de comercialização maior, ou seja, uma cota de comercialização mensal maior do que a devida (chamado de álcool papel), recebendo e antecipadamente e ao preço tabelado pelo governo (até fevereiro de 1999 cotado em R\$0,41 por litro de álcool hidratado).

\footnotetext{
${ }^{59}$ Neste sistema de velocidade de produção, calcula-se um fator baseado na relação entre a produção média diária desta safra e a produção média diária da safra passada (que pode ser maior, menor ou igual a um). A seguir, calcula-se a expectativa de produção da safra, multiplicando-se este fator pela produção da safra anterior. $O$ direito de comercialização mensal de cada unidade produtora é obtido dividindo-se a expectativa de produção da safra por 12.

${ }^{60}$ NASTARI, P. (Membro da Câmara Técnica do CIMA, DATAGRO) Comunicação Pessoal, 1999.
} 
Portanto, nesta forma de comercialização centralizada e comandada pelo governo, os produtores que informavam corretamente acabavam lesados, o que acabou sendo um dos fatores responsáveis pelo movimento pró-liberação almejado por um grupo de produtores.

Este sistema foi o que vigorou na safra 1998/99, embora nesta safra, além da mesa de comercialização já se encontrar bastante esvaziada, conviveram conjuntamente, devido a prorrogação da liberação de preços, o sistema de preços liberados e não liberados.

Segundo Rodrigues ${ }^{61}$ o esvaziamento da mesa de comercialização pode ser explicado pelo fato de que o excedente de oferta existente fez com que as cotas de comercialização geradas na mesa não fossem suficientes para o escoamento de toda a produção de álcool. Portanto, os recursos provenientes da mesa de comercialização não permitiam que os produtores honrassem seus compromissos, fazendo surgir um mercado informal de álcool, que chegou a representar $50 \%$ do mercado.

O mercado para aqueles produtores que só vendiam na mesa ficou bastante restrito, sendo que a situação se agravou mais com a liberação do mercado para as novas distribuidoras. Nesta fase, na mesa de comercialização restaram somente as distribuidoras do SINDICOM e os grandes produtores, sendo que as novas distribuidoras e grande parte dos produtores passaram a comercializar no mercado.

\subsubsection{Os contratos firmados entre produtores e distribuidoras e o adiamento da liberação dos preços}

O adiamento da liberação dos preços de novembro para maio de 1998 trouxe também problemas em outro elo da cadeia produtiva: o dos produtores de álcool e as distribuidoras de combustíveis. Na safra de 1998/99, contando com a liberação dos preços e da comercialização do álcool hidratado a partir de $1^{\circ}$ de maio, as distribuidoras de combustíveis e alguns produtores de álcool fecharam contratos de fornecimento, cujo

\footnotetext{
61 RODRIGUES, P.A. (Membro da Câmara Técnica do CIMA; Departamento de Planejamento e Economia da UNICA), Comunicação pessoal, 1999
} 
preço acordado entre as partes variava não apenas em função dos excedentes existentes, mas também conforme os valores do frete a serem pagos e a distância em relação aos centros consumidores.

Porém, com o adiamento da liberação de preços para novembro de 1998, surgiu uma grande confusão no mercado. O preço tabelado para o álcool hidratado continuou em $\mathrm{R} \$ 0,41$ por litro, fazendo com que alguns produtores de álcool quisessem receber os preços tabelados; por sua vez outros, que haviam firmado os contratos com as distribuidoras, embora em patamares de preços mais baixos, queriam receber os preços estipulados nos contratos previamente fixados.

Em junho de 1998 o Sindicato das Distribuidoras de Combustíveis (SINDICOM) e um grande número de produtores (aqueles que concordavam em receber os preços estabelecidos nos contratos) entraram na justiça com medida judicial contra o Ministro da Fazenda, visando manter os valores e as regras contratadas, tendo recebido a aprovação do judiciário de suas "tutelas antecipadas".

Embora possa parecer estranho que alguns produtores de álcool (principalmente os do Centro-Sul ${ }^{62}$ ), tenham entrado com medida judicial no sentido de poder vender fora da mesa do governo, e receber pelo seu produto um preço mais baixo do que o fixado, esta questão pode ser melhor entendida ao se considerar que o volume comercializado na mesa era muito inferior ao efetivamente comercializado na prática, e que a super oferta existente deprimia os preços, impedindo que no mercado se praticasse o preço tabelado. Então, os preços previamente fixados nos contratos, embora menores que os tabelados, eram superiores aos vigentes no mercado.

Annichinno $^{63}$ salienta que as medidas judiciais foram uma reação da COPERSUCAR (que produz $25 \%$ do álcool da região Centro-Sul) à situação existente: em virtude dos grandes estoques de passagem por ela detidos (hoje representando $55 \%$ do estoque total) e dos grandes excedentes existentes em relação ao volume

\footnotetext{
${ }^{62}$ A COPERSUCAR foi a primeira a entrar com liminar judicial.

6.3 ANNICHINNO, W. Membro do Conselho de Administração da Copersucar. Audiência Pública Conjunta com a Comissão de Agricultura e Política Rural e de Economia, Indústria e Comércio sobre o Setor Sucroalcooleiro. Brasília, Câmara dos Deputados, 15/04/1999.
} 
comercializado na mesa, era uma questão de sobrevivência vender aos preços estabelecidos nos contratos.

Por sua vez, segundo o Secretário Executivo do Ministério do Desenvolvimento, Indústria e Comércio Bolivar Barbosa Moura Rocha ${ }^{64}$, a prorrogação da liberação de preços de maio para novembro de 1998, e a decisão de que a comercialização de álcool deveria continuar na mesa de planejamento do governo, com preços tabelados - de certa forma contrariando o que o governo vinha perseguindo, a desregulamentação do setor - atendia um pedido veemente e contundente do próprio setor.

Era uma medida que visava sanear o mercado, que não se concretizou pela grande quantidade de ações judiciais movidas pelos próprios produtores de álcool, embora o Secretário reconheça que as ações judiciais atendiam em larga escala a necessidade de se vender álcool em quadro de excedente de oferta.

Os volumes comercializados mensalmente na mesa de comercialização, no mercado informal e através de contratos, no ano de 1998, na região Centro-Sul, estão na tabela 8 .

Tabela 8. Formas de comercialização, volumes mensais e preços de álcool hidratado - Região Centro - Sul (1998).

\begin{tabular}{|c|c|c|}
\hline & $\begin{array}{l}\text { Volume } \\
\left(\mathrm{m}^{3} / \mathrm{mês}\right)\end{array}$ & Preço $\left(\mathrm{R} \$ / \mathrm{m}^{3}\right)$ \\
\hline Mesa de Comercialização & 100.000 & $413^{(1)}$ \\
\hline Informal & 200.000 & $?$ \\
\hline Medidas Judiciais $^{(2)}$ & 220.000 & $?$ \\
\hline Total & 520.000 & \\
\hline
\end{tabular}

Fonte: CARVALHO, L.C.C. (1998). Comunicação pessoal.

(1) Preços teóricos, pois existem descontos entre o produtor e a distribuidora. Este valor corresponde a $\mathrm{R} \$ 286,40 / \mathrm{m}^{3}$ (estabelecido pela relação com a gasolina)+ $\mathrm{R} \$ 127,00 / \mathrm{m}^{3}$ (de subsídios).

${ }^{(2)}$ Contratos entre produtores e distribuidoras.

\footnotetext{
${ }^{64}$ Audiência Pública Conjunta com a Comissão de Agricultura e Política Rural e de Economia, Indústria e Comércio sobre o Setor Sucroalcooleiro. Brasília, Câmara dos Deputados, 15/04/1999.
} 
Segundo Carvalho ${ }^{65}$, é interessante salientar que em 1998 o Governo detinha o controle sobre apenas $1 / 5$ do volume de álcool hidratado consumido mensalmente (que ainda permaneciam na Mesa de Comercialização da ANP), e que os excedentes existentes de álcool (equivalentes a 2,5 meses de consumo) pressionavam os preços vigentes no mercado sensivelmente para baixo.

A super oferta de álcool levou as usinas a comercializarem, no início de 1998, o álcool hidratado por um preço aproximadamente $32 \%$ inferior ao tabelado ( $\mathrm{R} \$ 0,28$ o litro em comparação com os $\mathrm{R} \$ 0,41$ tabelado pelo governo). ${ }^{66}$

\subsection{As ações do CIMA durante o processo de desregulamentação}

\subsubsection{As compras de estoques de álcool}

Em janeiro de 1998 o CIMA emite sua primeira Resolução, que referia-se à aquisição de $90.000 \mathrm{~m}^{3}$ de álcool hidratado produzidos na Região Norte/Nordeste, pelo Ministério das Minas e Energia (através da Petrobrás), com recursos oriundos da arrecadação da parcela Frete de Uniformização de Preços (FUP).

Conforme a referida Resolução, a compra baseava-se no fato de que os elevados estoques excedentes existentes na Região Norte/Nordeste estava gerando dificuldades de processamento e estocagem da safra 97/98, acarretando a paralisação do processo produtivo em usinas e destilarias por insuficiência de tancagem própria, com conseqüente desẹmprego e tensão social.

Em abril de 1998 as estimativas apontavam para 1,8 bilhões de litros de álcool excedentes, que eram resultados dos estoques de passagem (já que na safra anterior as excelentes condições climáticas possibilitaram uma grande produção) e do saldo das importações da referida safra, quando foi comprado álcool em excesso. Aliado a estes fatores, a queda de consumo de álcool hidratado devido a redução da frota de veículos a álcool também contribuía para o excedente de oferta.

${ }^{65}$ CARVAlHO, L.C.C. (Membro da Câmara Técnica do CIMA, Superintendente da UNICA), Comunicação Pessoal, Outubro/1998.

66 "Cotação do álcool cai 31,7\%: há um excesso de oferta". Gazeta Mercantil, p.C-7, 13/05/1998. 
O excesso de oferta foi decisivo para uma drástica redução de preços pagos ao produtor em todo o Brasil. Nesta época, os preços já haviam caído $10 \%$ no Nordeste, em Minas Gerais a queda atingiu 25\%; em Pernambuco, 20\%; tendo sido de $30 \%$ em São Paulo ${ }^{67}$.

Os elevados volumes de estoques de passagem de álcool combustível existentes em meados de 1998, que pressionavam os preços do produto (com consequiências negativas sobre a manutenção da renda e do emprego do setor), podendo levar a paralisação do processo produtivo nas usinas e destilarias, e a ausência de financiamentos adequados para a estocagem do produto foram as razões que levaram o CIMA emitir sua terceira resolução.

Conforme a Resolução $N^{0}$ 3, de junho de 1998, o CIMA autorizava a Agência Nacional de Petróleo (ANP) a utilizar os recursos financeiros arrecadados pela Conta "Frete de Uniformização de Preços" para cobrir parcela dos custo de estocagem do álcool carburante, através de operação de financiamento a ser realizada entre as unidades produtoras de álcool carburante e o Banco do Brasil S.A. Segundo Rocha ${ }^{68}$, esta operação de financiamento, num montante de $\mathrm{R} \$ 200$ milhões de reais, permitiu o enxugamento do mercado de 600 milhões de litros.

Em agosto de 1998 o Conselho Interministerial do Álcool (CIMA), através da Resolução $N^{0} 4$, autoriza o Governo Federal a adquirir, das usinas e destilarias da região Centro-Sul, até 500 milhões de litros de álcool hidratado ao preço cheio de $\mathrm{R} \$ 0,41$ por litro (no mercado o produto era cotado em torno de $\mathrm{R} \$ 0,30$ ). Deste total, foram comprados 250 milhões de litros ${ }^{69}$, conforme Rocha. ${ }^{70}$

\footnotetext{
${ }^{67}$ Conforme o artigo "O excesso de oferta reduz o preço do álcool". Gazeta Mercantil, p.A-7, 15/04/99.

${ }^{68}$ ROCHA, B.B.M. Secretário Executivo do Ministério do Desenvolvimento. Audiência Pública Conjunta com a Comissão de Agricultura e Política Rural e de Economia, Indústria e Comércio sobre o Setor Sucroalcooleiro. Brasília, Câmara dos Deputados, 15/04/1999.

${ }^{69}$ Alguns produtores não têm acesso às aquisições de álcool feitas pelo governo em virtude de suas dívidas com o FGTS e INSS. Embora as Resoluções estipulem que as compras possam ser feitas "das unidades produtoras, ou dos sindicatos ou das cooperativas", os produtores não se organizaram de forma a permitir que mesmo aqueles com débitos com o governo pudessem participar das compras do governo. A Resolução do CIMA No 10 cancela a compra do saldo excedente desta Resolução.

${ }^{70}$ ROCHA, B.B.M. Secretário Executivo do Ministério do Desenvolvimento. Audiência Pública Conjunta com a Comissão de Agricultura e Política Rural e de Economia, Indústria e Comércio sobre o Setor Sucroalcooleiro. Brasília, Câmara dos Deputados, 15/04/1999
} 
Conforme a Resolução, os recursos são provenientes da conta Parcela de Preço Específico, sendo que o álcool a ser adquirido constituirá estoque regulador, que será recolocado no mercado interno nos prazos a serem estabelecidos pelo Comitê de Comercialização do Álcool Etílico Combustível (CAEC), devendo os recursos da venda serem retornados à referida conta.

É interessante notar que a compra dos excedentes de estoques existentes indicam que o governo enxergava que as medidas estatais intervencionistas de impor a prática dos preços tabelados tinham muito pouco efeito num ambiente de super oferta.

Esta sensibilidade por parte do governo fica demonstrada nos considerandos da Resolução, onde se reconhece que a política de prorrogaçăo de controle de preços não estava surtindo os efeitos desejados, devido aos altos excedentes, que fazia com que as empresas do setor se vissem obrigadas a descumprir os preços estipulados, com conseqüente queda de receita, o que as impossibilitava de pagar o preço de matériaprima nos valores fixados pelo governo. Da mesma forma, reconhecia-se a perda de renda dos trabalhadores agrícolas, com prejuízos no nível de emprego setorial.

Segundo Rocha ${ }^{71}$, Secretário de Acompanhamento Econômico do Ministério da Fazenda, o governo interviu para garantir o equilibrio de mercado e para assegurar a solidez e continuidade do Proálcool, dada a sua importância social, ambiental e estratégica.

Em janeiro de 1999 o CIMA determinou um levantamento dos estoques de álcool existentes em todo o País, de forma a se esclarecer a real disponibilidade de produto e de se definir qual o montante necessário do enxugamento do mercado. Além disso, nesta época era estudado o repasse do suporte diretamente ao produtor de álcool, para garantir seu recebimento pelos mesmos.

Em fevereiro deste mesmo ano foi emitida a Resolução № 10 do CMA, que estabelece uma nova aquisição pela PETROBRÁS de álcool etílico hidratado junto às destilarias ou às suas cooperativas ou associações, para a formação de estoques estratégicos do governo.

\footnotetext{
71 “Governo retoma o Proálcool”. Gazeta Mercantil, p. A-6, 17/08/1998.
} 
Conforme esta resolução, o preço de aquisição do produto foi reduzido de $R \$ 410,00$ (quatrocentos e cinqüenta reais por metro cúbico) para $R \$ 360,00$ (trezentos e sessenta reais) por metro cúbico, e os recursos oriundos da redução do valor do suporte ao álcool hidratado, que foi reduzido em $64,5 \%$ (passando de $\mathrm{R} \$ 0,127$ para $\mathrm{R} \$ 0,045$ por litro).

Desta forma, a compra de álcool pelo governo para a formação dos estoques estratégicos visava também o saneamento do mercado, com uma conseqüente recuperação dos preços praticados, que superasse as perdas dos produtores com a redução do suporte.

O volume a ser comprado foi posteriormente estipulado em $300.000 \mathrm{~m}^{3}$, pela Resolução do CIMA № 11, de março de 1999 e passou a trabalhar com um cenário da recuperação dos preços do álcool, devido ao enxugamento dos excedentes do produto do mercado.

Até abril de 1999, as compras efetivadas pelo governo foram as seguintes: $90.000 \mathrm{~m}^{3}$ da Região Norte/Nordeste, e $243.000 \mathrm{~m}^{3}$ da região Centro-Sul, ao preço de $\mathrm{R} \$ 0,41$ (quarenta e um reais por litro); totalizando um volume de $330.000 \mathrm{~m}^{3}$, num valor de $R \$ 136.530,00$ (cento e trinta e seis mil e quinhentos e trinta reais).

\subsubsection{A nova sistemática de aquisição de álcool pelo governo: os leilões}

A partir do mês de maio de 1999 aconteceu uma alteração na sistemática de aquisições de álcool hidratado pelo governo. As compras passaram a ser feitas através de leilões públicos, realizados por iniciativa do Ministério do Desenvolvimento, Indústria e Comércio $^{72}$. As Resoluções №s 12,13 e 14 do CIMA referem-se aos leilões públicos, estabelecendo algumas regras e princípios a serem seguidos nos leilões.

Estas resoluções dispõem que os mesmos serão feitos pelo Sistema de Interligação Eletrônica de Bolsas de Mercadorias do Banco do Brasil S/A, segundo condições expressas em Edital de Compra Específico; que o Secretário-Executivo do

\footnotetext{
${ }^{72}$ O Diário Oficial de 06 de maio de 1999 traz o edital de compra de álcool etílico combustível segundo esta nova forma de comercialização.
} 
CMA poderá instruir o Coordenador de Leilão (a ser indicado pelo SecretárioExecutivo) a estabelecer preços mínimos para o fechamento de negócios durante o pregão; além de cancelarem alguns artigos de resoluções anteriores, dentre eles o que fixava em $\mathrm{R} \$ 360$ reais por metro cúbico o preço das aquisições de álcool hidratado.

Em relação aos leilões, o Secretário Executivo do CIMA, Bolivar Moura Rocha $^{73}$ afirmou que na primeira compra via leilões serão adquiridos 100 milhões de litros, de um total que deve exceder 400 milhões de litros nos próximos meses. Salientou também que o governo fará todo o possível para reduzir a maior crise já enfrentada pelos produtores de álcool (cujo preço hoje está oscilando entre $\mathrm{R} \$ 0,14$ e $\mathrm{R} \$ 0,17$ ), não descartando a hipótese de dar um passo atrás, centralizando temporariamente as compras pelo governo.

A primeira compra feita pelo governo (via Petrobrás), com o objetivo de formação de estoques reguladores, pelo sistema de leilões foi realizada no dia 20/05/1999. Pelo sistema eletrônico do Banco do Brasil foram ofertados 100 milhões de litros, sendo vendidos $99,77 \%$, ao preço de $\mathrm{R} \$ 0,26$ por litro. A expectativa é que as compras governamentais sejam feitas semanalmente, através deste sistema.

Porém, já na fase inicial de implantação desta nova sistemática de comercialização começam a surgir alguns problemas com os leilões devido a suspeita de manipulação dos preços da venda do produto ao governo. Conforme o ministro do Desenvolvimento, Indústria e Comércio Celso Lafer $^{74}$, os leilões poderiam ser suspensos caso fique comprovado que as empresas do setor estão manipulando os preços, já que o governo não tem a intenção de manter um leilão que possa ser visto como subsídio.

Portanto, fica claro que embora o governo tenha clareza das dificuldades encontradas pelo setor nesta transição de uma intervenção estatal profunda e intensa para o livre mercado, e que reitere inúmeras vezes que definiu seu interesse pela continuidade do Programa (dadas as questões relevantes de se utilizar um combustível renovável, limpo, no qual o País foi pioneiro, com patrimônio reconhecido internacionalmente,

\footnotetext{
73 "Governo socorre produtor de álcool". Estado de São Paulo, p. B-8, 15/5/99.

74 "Leilöes de venda do álcool anidro podem ser suspensos". O Estado de São Paulo, p.B-6, 01/06/99.
} 
amplamente gerador de empregos), tem encontrado dificuldades para conseguir formar seu eștoque estratégico e contribuir para sanear o mercado.

Deve ser lembrado que estas dificuldades são inerentes do novo ambiente institucional democrático, no qual as decisões do governo não são mais tomadas de forma autoritária e centralizada, sendo mais abertas e transparentes, nas quais a opinião da sociedade passa a ter relevância maior.

\subsubsection{Outras medidas tomadas pelo CIMA: incentivos à demanda}

Dada a grave crise instalada no setor, diversas medidas eram pleiteadas pelos produtores, tanto no sentido de se aumentar a demanda pelo produto como para reduzir a oferta. Dentre elas destacam-se a elevação do percentual do álcool anidro na gasolina; a retirada da adição do MTBE como oxigenado na gasolina do Rio Grande do Sul (conforme estipulado pela lei); e, a compra dos estoques estratégicos de álcool pelo Governo.

Diversas medidas foram tomadas durante o processo de desregulamentação no sentido da consolidação do mercado de álcool. Conforme Serodio (1999), destacam-se:

- o aumento do percentual do álcool anidro à gasolina de $22 \%$ para $24 \%$ (Decreto $\mathrm{N}^{\mathrm{o}}$ 2.607, de maio de 1998), que proporcionou um consumo adicional de álcool da ordem de $400.000 \mathrm{~m}^{3}$ por ano;

- a suspensão do uso da mistura MEG, que aumentou o consumo de álcool em $300.000 \mathrm{~m}^{3}$

- a elevação temporária do imposto de importação de álcool ${ }^{75}$ (que passou para $35 \%$ ), evitando a importação de $700.000 \mathrm{~m}^{3}$ de álcool;

- a substituição do MTBE, no Rio Grande do Sul, por álcool anidro, que deve gerar um consumo adicional de $400.000 \mathrm{~m}^{3}$.

\footnotetext{
${ }^{75}$ A tarifa externa comum do imposto de importação do Mercosul é de $20 \%$; foi negociado este aumento temporário de $35 \%$, que obedece a um cronograma de reduções anuais, devendo chegar novamente aos $20 \%$ no ano 2001.
} 
Além destas, em junho de 1998 mais uma medida visando incentivar a demanda por álcool hidratado foi tomada, estabelecendo-se a substituição gradual da frota oficial para veículos a álcool (Lei № 9.660, de junho de 1998).

Conforme Machado (1998), a elevação do percentual da mistura de álcool na gasolina e a adoção da frota verde pelo governo são medidas importantes para a revitalização do Proálcool, mas não suficientes, faltando uma definição do governo quanto ao papel do álcool na matriz energética brasileira e o novo arranjo institucional do Proálcool.

Segundo o autor, o governo deveria considerar outras questões além das econômicas (já que o álcool não é competitivo com a gasolina em termos estritamente monetários), tais como sua vantagem ambiental, o fato de ser um recurso renovável, de ser produzido em larga escala e sua produção gerar milhares de empregos, além da economia de divisas gerada pela redução da importação de petróleo.

Serodio (1999) salienta que por recomendação da Câmara Técnica, algumas medidas foram levadas ao CIMA, visando a consolidação do mercado de álcool, que referendou:

- o direcionamento do incentivo físcal federal (IPI) para as aquisições de veículos leves de passageiros (taxis) movíveis a combustível de origem renovável;

- especial atenção às disposições da Lei 9.660/98 (que estabelece que num prazo de 5 anos a frota oficial deve ser a álcool), sobre aquisições e locações de veículos oficiais;

- especial atenção aos carros movidos a álcool, em eventual programa de estímulo à renovação da frota de veículos leves. ${ }^{76}$

\footnotetext{
${ }^{76}$ Esta medida é muito importante quando se considera que $90 \%$ da frota com mais de dez anos é a álcool, se não houver sistema para renovar carro a álcool somente por carro a álcool, o sucateamento da frota a álcool será mais rápido ainda.
} 
Uma questăo prioritária que também está sendo avaliada pelo governo é a substituição da atual fonte de recursos para a cobertura dos dispêndios com programas de produção e uso do álcool combustível (atualmente oriundos da conta Parcela Preços Específica), que se esgota em agosto do ano 2.000. Conforme Serodio (1999), busca-se uma forma de tributação diferenciada sobre os combustíveis, o que requer o apoio do Congresso.

\subsection{As manifestações dos agentes em defesa do setor Sucroalcooleiro}

Entre março e junho de 1999 diversas manifestações públicas (amplamente divulgadas na mídia) foram realizadas pelos agentes ligados a cadeia sucroalcooleira, objetivando sensibilizar a sociedade e os Governos Estaduais e Federal para os problemas enfrentados pelo setor (dada a liberação e a crise de super oferta existentes), e também para mostrar sua importância econômica e como fonte geradora de empregos.

O primeiro manifesto, denominado "Pró-Cana", foi realizado no Centro Cívico da cidade de Piracicaba (SP), em março de 1999, sob a coordenação da Prefeitura Municipal, através da Secretaria de Agricultura, juntamente com a Associação dos Fornecedores de Cana (Orplana), e com a Cooperativa dos Plantadores da Cana de Piracicaba (Coplacana). Participaram do evento dois Secretários de Estado, representantes do Governo Federal e do setor privado, e aproximadamente 400 pessoas.

$\mathrm{O}$ ato objetivou mostrar a importância sócio econômica da agroindústria da cana-de-açúcar na região de Piracicaba, que participa com $17 \%$ da produção do Estado de São Paulo. Na ocasião foram ressaltados pelo prefeito da cidade o número de empregos gerados pela atividade, a assistência social aos trabalhadores, a receita dos municípios canavieiros, e a necessidade de incentivo à produção do álcool. Diversas reivindicações relativas ao estímulo ao uso do álcool combustível foram apresentadas na ocasião. Após o encontro, os participantes desfilaram em carreata pelas ruas centrais da cidade, para ressaltar a importância do setor para a economia local.

No mês de abril eclodiram vários movimentos em defesa do uso do álcool combustível e manutenção dos empregos. O primeiro foi nas ruas centrais de Araraquara 
(SP), e reuniu trabalhadores e usineiros, em defesa do uso do álcool combustível, visando a recuperação da agroindústria canavieira e manutenção dos empregos do setor. A manifestação reuniu cerca de 2.000 trabalhadores.

A seguir, ainda em abril, quatro rodovias da Alta Paulista foram fechadas em protesto contra o desemprego. Desta vez, 15.000 trabalhadores da atividade sucroalcooleira de São Paulo paralisaram, ao mesmo tempo, trechos de quatro rodovias do Estado de São Paulo, com o objetivo de alertar a comunidade e os responsáveis pelas políticas referentes ao setor, sobre os fatos e as conseqüências do desemprego em massa provocado pela crise vivida. Os protestos receberam o apoio da Federação e Sindicatos de Trabalhadores ligados à atividade.

$\mathrm{Na}$ ocasião os manifestantes distribuíram um folheto explicativo intitulado: "Manifesto para a Preservação do Meu e do Seu Emprego na Atividade Sucroalcooleira". As principais reivindicações do movimento referiam-se a uma definição clara do governo quanto à política do uso do álcool combustível; o incentivo à demanda do carro a álcool pela isenção temporária de impostos; a adoção do álcool anidro como aditivo ao óleo diesel; o controle do Governo sobre a evasão fiscal na venda de combustíveis; e, a garantia da paridade entre os preços do álcool e da gasolina.

Neste mesmo mês foi lançado, em Ribeirão Preto (SP), por trabalhadores e empresários o movimento denominado "Grito contra o Desemprego e pela Produção". Da mesma forma que os demais, as reivindicações eram no sentido de valorizar o uso do álcool combustível, através de uma política que assegure o nível de emprego e permita o escoamento da produção.

Nesta ocasião foram entregues ao então Ministro da Agricultura Francisco Turra a ao Secretário da Agricultura do Estado de São Paulo, João Carlos Meireles um documento com as reivindicações em favor do Proálcool, e empresários e trabalhadores percorreram em um comboio formado por aproximadamente 800 caminhões e tratores os $20 \mathrm{~km}$ entre Sertãozinho (a principal cidade produtora de álcool do País) e Ribeirão Preto. 
No mês de maio houve um protesto das destilarias de álcool da Alta Noroeste, que distribuíram 20.000 litros de álcool grátis na principal rodovia de acesso à Araçatuba (SP). O protesto foi contra a falta de política do governo federal que incentive o uso do combustível alternativo, e teve o apoio dos sindicatos de trabalhadores ligados ao setor.

Neste mesmo mês o Governador Mário Covas solicitou uma audiência com o Presidente da República para discutir os problemas da agroindústria sucroalcooleira. As lideranças do setor foram ouvidas pelo presidente Fernando Henrique Cardoso ainda em maio.

Em junho foi a vez dos produtores rurais, usineiros e trabalhadores das regiões de Jaú, São Manoel, Barra Bonita, Bocaina, Brotas, Bariri, Macatuba, Lençóis Paulista (todas no Estado de São Paulo), organizarem um manifesto na cidade de Jaú (SP).

A concentração reuniu cerca de 9.000 pessoas que reivindicaram uma política de comercialização e utilização do álcool para evitar o sucateamento de toda a estrutura de produção montada, e o desemprego em massa que ameaça atingir a região.

No mesmo dia outro manifesto, reunindo empresários, trabalhadores e políticos, aconteceu na cidade de Valparaíso (SP), com pessoas de diversas cidades da região produtoras de álcool. Os 1.000 manifestantes se reuniram nas ruas centrais da cidade, focalizando a questão do desemprego que vem tomando conta da região devido a diminuição da produção de álcool nas destilarias da região. Foi ressaltado que $67 \%$ dos recursos da cidade de Valparaíso são oriundos da atividade alcooleira, e que diversos serviços que foram municipalizados pelo Governo Federal dependem da manutenção das atividades do setor.

Finalmente, no mês de junho foi realizado um ato em Brasília denominado "Dia Nacional de Luta pelo Emprego", que reuniu produtores de cana-de-açúcar, de açúcar, de álcool, de trabalhadores, de sindicalistas, autoridades e parlamentares. O manifesto foi realizado simultaneamente em vários municípios canavieiros (Capivari, Catanduva, Jaú, Lençóis Paulista, Piracicaba e Sertãozinho). 
As manifestações em Brasília e nos diversos municípios canavieiros objetivaram sensibilizar o governo, as montadoras, distribuidoras e a sociedade para a crise enfrentada pelo setor, com sérias conseqüências sobre o emprego.

A passeata em Brasília, que reuniu 6.000 trabalhadores do setor, ocorreu na Esplanada dos Ministérios e teve como principal reivindicação a revitalização do Proálcool e a garantia de 1,2 milhão de empregos, sendo amplamente divulgada pela mídia. Diversos prefeitos e representantes de vários estados (Minas Gerais, Goiás e de estados nordestinos) também participaram do movimento.

Alguns participantes discursaram em palanque montado em frente ao Congresso Nacional $^{77}$, sendo que o ponto alto da manifestação foi quando o Ministro do Trabalho e do Emprego, Francisco Domelles atendeu ao chamado dos sindicalistas, subiu no palanque e discursou em apoio à manifestação.

\subsection{O Pacto pelo Emprego no Agronegócio Sucroalcooleiro}

Em 17de agosto de 1999 o governo do Estado de São Paulo, o Governo Federal, governos de diversos municípios canavieiros, a indústria automobilística, a indústria de açúcar e álcool, os trabalhadores ligados ao setor, e as distribuidoras de combustíveis assinaram, em São Paulo, o "Pacto pelo Emprego", que foi considerado o início de um novo modelo de gestão do setor, dada a desregulamentação do mesmo.

Além do governador Mário Covas, assinam o pacto quatro ministros, sete secretários estaduais, doze presidentes de federações ou sindicatos de patrões ou empregados ligados ao setor sucroalcooleiro, e um representante da Assembléia Legislativa do Estado.

\footnotetext{
${ }^{77}$ Dentre eles os deputados Luís A. de Medeiros, Roberto Balestra, Francisco Graziano, João Herrmann Neto e José Machado; representando os trabalhadores, os sindicalistas Paulo Pereira da Silva (presidente da Força Sindical e do Sindicato dos Metalúrgicos de São Paulo, Danilo Pereira (presidente da Federação dos Trabalhadores nas Indústrias Químicas e Farmacêutica); Melquíades de Araújo (vice-presidente da Força Sindical e coordenador do movimento) e Antônio Vitor (coordenador do "Grito pelo "Emprego e pela Produção", de Ribeirão Preto); pela AMCESP. Antônio Mendes Thame, e representando os fornecedores, Antônio Celso Cavalcanti (FEPLANA) e Maria Cristina Pacheco (Orplana).
} 
O pacto é válido até o ano de 2005, com avaliações anuais, e objetiva conter o desemprego no setor, através do fortalecimento de uma atividade econômica que representa 35\% do PIB rural de São Paulo e gera 600.000 postos de trabalho. Cada um dos envolvidos assumiu uma série de compromissos (ver Anexo C), que são resumidos a seguir.

O Governo Federal deve monitorar a execução das políticas acordadas pelos agentes, de forma a compatibilizar a fabricação de produtos e subprodutos da cana-deaçúcar, para garantir seu abastecimento.

Além disso, adotar medidas de estímulo à demanda (adoção de frotas verdes, estender a isenção do IPI para a locadora de veículos; implantar a mistura de $26 \%$ de álcool anidro à gasolina; completar as pesquisas de mistura de $3 \%$ no diesel); dar preferencialmente incentivos para a produção de carros a álcool; abrir novos mercados para exportação de álcool carburante; lutar contra barreiras protecionistas de países que subsidiam os produtos deste setor; lutar contra a sonegação fiscal no álcool; estabelecer regulamentação e mecanismos que estimulem a co-geração de energia elétrica a partir de bagaço da cana e sua comercialização; e manter as compras de álcool para a formação dos estoques de segurança.

O Governo do Estado de São Paulo assumiu os seguintes compromissos: o monitoramento do pacto no âmbito da Câmara Paulista do Setor Sucroalcooleiro; dar isenção de 100\% no IPVA (Imposto sobre Propriedade de Veículos Automotores) de 1999 e 2000 para as compras de carro a álcool feitas até 31 de dezembro de 1999; viabilizar a redução da alíquota de ICMS do álcool hidratado com aumento compensatório da alíquota sobre a gasolina; conseguir isenção de ICMS para o táxi a álcool no âmbito do Conselho de Política Fazendária (Confaz); dar prioridade de formação de frota de veículos a álcool (Frota Verde); testar a mistura álcool-diesel, e estimular a implantação de projetos de co-geração em destilarias e usinas de álcool e açúcar. 
Os Governos dos municípios canavieiros se comprometeram em: devolver a parcela do IPVA referente aos municípios aos compradores de carros novos a álcool, e a excluir o carro a álcool das políticas municipais de rodízios.

Tanto o Governo Federal como o Estadual, bem como os governos municipais integrantes da AMCESP devem participar e apoiar as iniciativas de requalificação dos trabalhadores do setor sucroalcooleiro, que é uma ação de fundamental importância quando se considera o desemprego gerado pela adoção da mecanização da lavoura.

Aos empresários da indústria do açúcar e do álcool cabe a manutenção do emprego e a garantia de abastecimento deste combustível; a doação de 1.000 litros de álcool para os compradores de veículos a álcool; estabelecer parcerias com o governo e trabalhadores para a reciclagem da mão-de-obra; e apoiar os programas que incentivem o uso do álcool carburante.

As montadoras se responsabilizaram em produzir e manter o mercado abastecido de veículos a álcool, e dar continuidade às pesquisas para o desenvolvimento do carro a álcool. Os trabalhadores se comprometeram em desenvolver programas de requalificação profissional, e as distribuidoras de combustiveis em garantir a infraestrutura de abastecimento do produto.

O acompanhamento dos compromissos assumidos no Pacto, sua estrutura e estratégia de execução serão feitos pela Câmara Paulista do Setor Sucroalcooleiro, sendo criados, no âmbito desta Câmara, o Grupo Executivo (GESS), formado pelos representantes dos fornecedores (ORPLANA), produtores de álcool e açúcar (SIAESP/SIFAESP), das federações de trabalhadores, da Associação dos Fabricantes de Veículos (ANFAVEA), do Sindicato de Distribuidoras (SINDICOM) e dos municípios canavieiros (AMCESP). O Secretário da Agricultura e Abastecimento, como representante do Governo do Estado, será o Secretário Executivo do GESS. 


\section{S FERRAMENTAL TEÓRICO}

A redução da intervenção estatal na economia brasileira como um todo - e especificamente no setor sucroalcooleiro - fez emergir a questão central deste estudo que é identificar até que ponto o Estado pode se afastar deste setor, e caso ele não possa se retirar totalmente, quais as novas formas requeridas da ação estatal.

Para se analisar esta questão o ferramental teórico adotado foi a Microeconomia tradicional, na vertente da Organização Industrial, que determina quais as condições de um mercado que podem tornar necessária a intervenção estatal. Desta forma, no trabalho procura-se verificar a existência de falhas de mercado nos elos da cadeia produtiva que justifiquem a intervenção estatal, cuja natureza vai depender dos tipos de imperfeições existentes.

Além desta questão central - qual o papel atual do Estado no setor sucroalcooleiro - a desregulamentação trouxe outras duas questões importantes. A primeira refere-se a como as mudanças institucionais, decorrentes da desregulamentação, afetam as relações entre os agentes da cadeia produtiva e o seu próprio desenvolvimento econômico. Para se estudar esta questão utilizou-se a Nova Economia das Instituições, (nas vertentes de Oliver Williamsom (1985) e Douglas North (1990)), com a qual pretende-se identificar as características das transações e os arranjos contratuais emergentes mais eficientes, e as tendências de reorganização da cadeia produtiva dada a mudança no ambiente institucional.

A segunda questão a ser analisada é, no contexto político, quais os novos atores sociais (públicos e privados), seus interesses, objetivos e recursos de poder, que resultam 
em políticas concretas que afetam os destinos do setor. Para o estudo desta última questão, que refere-se aos mecanismos decisórios envolvidos num processo de tomada de decisão pelo governo, serão usados conceitos sobre os Determinantes Políticos dos Processos Decisórios, de forma a se analisar o porquê de algumas escolhas governamentais feitas ao longo do processo de desregulamentação.

Esta seção é dividida em três partes, cada qual expondo algumas considerações sobre cada um dos instrumentais teóricos. Na primeira parte são feitas algumas observações sobre Organização Industrial, com ênfase em Regulamentação de Mercados; na segunda são apresentadas algumas idéias e críticas sobre a Nova Economia das Instituições; sendo que a terceira parte refere-se a alguns conceitos sobre os Determinantes Políticos dos Processos Decisórios.

\subsection{Regulamentação de mercados}

Atualmente uma questão bastante importante que se coloca é a redefinição do papel do Estado como promotor do desenvolvimento econômico. $\mathrm{Na}$ área agrícola, onde os governos, de uma forma geral, têm uma tradição de intervenção longa e intensa, os desafios desta mudança são grandes.

Conforme Petit (1995), a definição do papel do governo e do setor privado para garantir um desenvolvimento econômico sustentável é o grande obstáculo a ser enfrentado, principalmente quando se consideram os déficits fiscais crescentes em muitos países em desenvolvimento, que exigem mais atenção para as opções de liberação de mercados e privatizações.

Segundo este autor, embora atualmente a liberação dos mercados seja um assunto tão discutido, ele já fazia parte de um dos debates mais antigos da economia: a invenção da mão invisível de Adam Smith foi uma reação às convicções prevalescentes entre os mercantilistas de que o governo tinha um papel importante a desempenhar na determinação da prosperidade das nações. Entre a mão invisível da Adam Smith e a intervenção profunda do Estado, é necessário definir o tipo e a natureza da intervenção adequada. 
Farina et al. (1997) salientam que segundo as teorias normativas de regulamentação (que têm como padrão de referência o mercado competitivo e a hipótese da racionalidade ilimitada dos agentes), a intervenção estatal é necessária quando as transações impessoais via mercado, baseadas no sistema de preços, falham em proporcionar um sistema eficiente de alocação de recursos. Neste caso, o preço de equilíbrio não estaria refletindo adequadamente a avaliação do consumidor ou os custos dos recursos econômicos utilizados na fabricação do produto, e a intervenção do Estado seria no sentido de se controlar as falhas de mercado existentes.

\subsubsection{As falhas de mercado e suas correções}

Portanto, a natureza e o tipo de intervenção governamental em dado setor vão depender das falhas de mercado ${ }^{78}$ existentes, tais como: a existência de bens públicos, a presença de externalidades, os problemas de "moral hazard", a existência de monopólios e a proteção às "indústrias nascentes". Conforme Farina et al. (1997) para cada tipo de falha de mercado existe uma forma de ação por parte do Estado mais adequada, listadas a seguir:

- regulamentação social;

- regulamentação econômica;

- política antitruste; e,

- política industrial.

A regulamentação social é usada para os casos de existência de externalidades, bens públicos e problemas de informação entre os agentes. A regulamentação econômica é indicada quando verifica-se o exercício do poder de monopólio decorrente da existência do monopólio natural. Por sua vez, quando o poder de monopólio deriva de estruturas de mercado oligopolistas, deve-se adotar uma política antrituste, de forma a impedir que estruturas concentradas levem à adoção de estratégias anti-competitivas.

\footnotetext{
${ }^{78}$ Pindyck \& Rubinfeld (1988, p.793-796) e Farina et al (1997, p.115) tratam das falhas de mercado (poder de mercado, informação incompleta, externalidades, e bens públicos).
} 
Finalmente, a política industrial aplica-se quando existem falhas intertemporais de mercado, objetivando promover setores industriais estratégicos, postergando o problema da concorrência interna e externa. A seguir relaciona-se as formas de ação do Estado apropriadas às principais falhas de mercado existentes.

\subsubsection{Regulamentação social: bens públicos, externalidades e problemas de informação}

Uma das falhas de mercado listada na literatura econômica é a existência de bens públicos, a qual pode justificar uma regulamentação social, já que dificilmente o seu fornecimento por empresas privadas será eficiente. Os bens públicos têm a característica de serem simultaneamente não-rivais e não exclusivos, ou seja, uma vez produzidos o número de consumidores não altera seu custo de produção e não há como excluir os agentes de sue consumo.

Conforme Pindyck \& Rubinfeld (1994) uma mercadoria é não-rival quando, para qualquer nível de produção, seu custo marginal é zero para um consumidor adicional, ou seja, consumidores extras não ocasionam custos. Como exemplos de bens não rivais são citados o uso de um farol por um navio: se mais uma embarcação se utilizar do farol não haverá custos adicionais; da mesma forma, se mais um telespectador assistir uma televisão estatal não será acrescido nenhum custo aos já existentes. Portanto, o consumo de mercadorias não-rivais pode ser feito sem prejudicar o uso do bem por outras pessoas.

Por sua vez, uma mercadoria é não-exclusiva quando as pessoas não podem ser excluídas do seu consumo, fazendo com que possa ser utilizada sem que se pague por ela. Não existe maneira de oferecer o bem ou serviço sem que todos sejam beneficiados, ou seja, as pessoas não são estimuladas a pagar pelo bem o valor que ele realmente tem. O fato dos consumidores não poderem ser excluídos induz ao comportamento "freerider" (carona), que é o consumo do produto sem arcar com o custo de sua provisão. Os autores citam como exemplo de bens não-exclusivos um programa de erradicação de pernilongos numa cidade: não existe uma maneira de fazê-lo sem que todos se 
beneficiem, e os indivíduos podem atuar como "caronas", usufruindo do serviço sem pagar por ele.

Quando as mercadorias são ao mesmo tempo năo-exclusivas e não-rivais são denominadas bens-públicos, e são aquelas que oferecem benefícios às pessoas a um custo marginal zero e ninguém pode ser excluído do seu consumo. Desta forma, as firmas não conseguem obter lucros na sua produção, o que requer que o governo os forneça diretamente ou financie sua produção, já que de outra forma sua oferta será subótima.

Além disso, o Estado pode atuar usando seu poder para a fixação de taxas para que tanto os beneficiários diretos como os indiretos paguem por ele. Exemplos de bens públicos são programas de erradicação de pragas agrícolas, pesquisa básica, informação (por exemplo levantamentos censitários).

Outra falha de mercado existente é a presença de externalidades - positivas ou negativas - que ocorrem quando alguma atividade de produção ou consumo impõe custos ou se apropria de benefícios de outros agentes que não fazem parte da atividade, sem que este efeito se reflita nos preços de mercado. Normalmente requerem ação governamental, no sentido de corrigir os balanços entre a produção a demanda e a alocação de recursos inadequada, através de regulamentos ou taxas para reduzir (ou ampliar) seus efeitos.

Exemplos da regulamentação estatal no caso de externalidade negativa são as normas sobre o controle de emissão de poluentes, sobre o meio ambiente, sobre o uso de um recurso natural. A necessidade de regulamentação no caso das externalidades positivas decorre de que normalmente elas não permitem que se aproprie dos retornos dos investimentos realizados, levando a produção sub-ótima.

Farina et al. (1997) cita que em alguns casos o governo se encarrega da produção dos bens ou serviços a elas associados (tais como a criação de novas variedades agrícolas) ou regulamenta o mercado (por exemplo a elaboração de uma legislação sobre patentes industriais, que estimule investimentos privados em novos produtos). 
Outra falha de mercado que pode justificar uma regulamentação estatal decorre da informação assimétrica ou imperfeita ${ }^{79}$. A informação complexa ou custosa pode levar os agentes tomarem decisões em relação às mercadorias, serviços ou trabalhos potencialmente perigosas. Da mesma forma, pode levar os produtores a tomarem decisões relativas à qualidade dos produtos de maneira inadequada.

Conforme Noll (1989) a regulação nestes casos pode trazer dois tipos de ganhos de eficiência: o primeiro, é pelo aumento da informação, que reduz as incertezas nas decisões tomadas, melhorando a eficiência do mercado em atender consumidores e vendedores; o segundo é que através de padronizações mínimas, pode proteger os participantes desinformados de maus resultados.

Desta forma, surgem os problemas de moral hazard (risco moral), decorrentes da informação assimétrica entre as partes, que impede que os mecanismos de mercado operem eficientemente, e requerem ação governamental porque se as informações não forem suficientes, as decisões dos agentes se afastarão do ideal do modelo da concorrência perfeita.

A comercialização de diversos produtos (remédios, alimentação, itens de segurança, substâncias tóxicas, dentre outros) requer a regulamentação estatal devido aos riscos que a informação assimétrica ou imperfeita impõe aos consumidores.

\subsubsection{Regulamentação econômica: poder de monopólio decorrente do monopólio natural}

O poder de monopólio também é uma falha de mercado que requer ação governamental de forma a se evitar condutas anti-competitivas e resultados menos eficientes. Conforme Farina (1994), quando o monopólio ou oligopólio é resultante da presença de subaditividade de custos, a produção eficiente é aquela feita em poucas ou mesmo em uma só firma, de forma a aproveitar as economias de escala e escopo existentes.

\footnotetext{
${ }^{79}$ Conforme Farina et al. (1997, p.117): "A informação é assimétrica quando os agentes envolvidos nas transações dispõem de quantidade e qualidade diferenciada de informação. A informação é imperfeita quando o agente não consegue listar toda a informação necessária".
} 
Porém, neste caso, não há como garantir que o consumidor se beneficiará da produção de menor custo, já que não existe a força da concorrência para garantir o nível ótimo de preços. Desta forma, a regulamentação econômica (ou a operação por empresas estatais) vêm substituir as forças de mercado ausentes.

É necessária a intervenção governamental para se estimular a competição dos mercados e evitar o exercício do poder de monopólio, que é a capacidade que o monopolista tem de reduzir a produção do bem e fixar seu preço acima do custo marginal, fazendo surgir uma perda líquida de bem estar social, decorrente da redução líquida do excedente apropriado pelos agentes econômicos.

Neste caso surge um "peso morto", que não é apropriado nem pelo monopolista nem pelo consumidor, que pode ser mensurado através da comparação entre o excedente total e o preço do monopólio, e entre o excedente total e o preço da competição prefeita. Portanto, o bem-estar geral é menor em mercados monopólicos do que mercados concorrenciais.

Nos casos de monopólios naturais ${ }^{80}$, a regulamentação econômica é feita através de agências governamentais, que controlam o fornecimento dos bens ou serviços, estabelecendo padrōes de qualidade e preços dos produtos.

\subsubsection{Política antitruste: poder de monopólio devido às estruturas concentradas}

Por sua vez, quando o poder de monopólio deriva de estruturas de mercado oligopolistas, a ação do Estado deve ser no sentido de adotar uma política antitruste, de forma a impedir o exercício do poder de monopólio.

Segundo Scherer (1980), para conciliar o comportamento maximizador de lucros das empresas privadas com o interesse dos consumidores, o governo pode se utilizar da legislação antitruste, que objetiva proteger ou intensificar as forças competitivas dos mercados, já que por hipótese esta é a melhor forma de se atingir a eficiência econômica.

\footnotetext{
${ }^{80}$ No monopólio natural a empresa apresenta custos médios e marginal declinantes para toda sua produção. Neste caso, é mais eficiente que apenas uma empresa abasteça o mercado inteiro (Pyndyck \& Rubinfeld, 1994).
} 
A hipótese concentração-coalizão ${ }^{81}$ faz com que se transponham aos mercados oligopólicos as consequiências atribuídas ao monopolista, requerendo igualmente a atenção do governo.

Embora diversos estudos tenham enfraquecido esta hipótese ${ }^{82}$, e mesmo que se considere a hipótese de que o cartel não é uma organização sustentável (porque é difícil manter a fidelidade dos participantes dos acordos, e consequentemente a estabilização dos mesmos, dados os incentivos existentes para comportamento "free-rider"), existe o problema do tempo verificado até sua desintegração, que pode ser longo o suficiente para afastar os concorrentes.

As leis antitrustes lidam com o exercício do poder de monopólio de duas formas: a primeira é aproximando a estrutura do mercado à competitiva (por exemplo evitando fusões, aquisições, etc.); a outra é proibindo certos tipos de conduta indesejáveis por parte dos agentes.

Em relação ao controle da concentração dos mercados, Farina (1994) salienta que a contribuição imprecisa que a teoria econômica fornece para o controle das estruturas de mercado enfraquece a legislação antifusões (anti-merger) e aquisições, e observa as dificuldades empíricas de se determinar o nível ótimo de concentração compatível com a eficiência.

Para certa fatia de mercado ser considerada uma infração da ordem econômica, ela deve ser tal que iniba a concorrência e que permita o exercício do poder de monopólio. A dificuldade surge porque não existe na teoria econômica uma base sólida para se estipular um grau de concentração de mercado ideal, que evitasse o poder de monopólio, ou seja, um "market-share" de $20 \%$ do mercado não implica em exercício do poder de monopólio. A teoria econômica fornece critérios para se analisar os processos

\footnotetext{
${ }^{81}$ Segundo a qual quanto menor o número de participantes do mercado, mais a solução de equilibrio do oligopólio se aproxima do resultado do monopólio, devido a maximização conjunta de lucros, já que quanto maior a concentração, maior a possibilidade de acordo tácito ou explícito entre as empresas.

82 Tais como os modelos dos super-jogos, que apresentam tanto resultados que se aproximam do monopólio como da concorrência perfeita; a teoria dos mercados contestáveis, segundo a qual mesmo estruturas concentradas podem ter desempenho próximo da concorrência perfeita desde que o mesmo seja perfeitamente contestável.
} 
de fusões e aquisições, envolvendo questões de eficiência técnica e de economias de custos de transação.

Conforme Farina (1994), fatores como subaditividade de custos e especificidade de ativos (sujeitos a custos irrecuperáveis) devem ser considerados na análise das fusões e aquisições: se o setor é caracterizado por subaditividade de custos, mas eles não forem irrecuperáveis, a concorrência potencial ou efetiva de outros participantes poderá contestar o poder de mercado; por sua vez, se a subaditividade de custos vier acompanhada de ativos específicos, provavelmente será necessária uma regulamentação para se evitar o poder de monopólio.

Portanto, a caracterização dos ativos (físicos ou humanos) torna-se um fator importante de decisão: na presença de especificidades, espera-se que os ganhos advindos das fusões e aquisições sejam ganhos de eficiência tão importantes quanto os tecnológicos. Para ativos de uso geral, provavelmente o objetivo das mesmas seja a redução da concorrência

Com a evolução da teoria da organização industrial e da maior abertura do comércio internacional (ampliando os mercados relevantes a serem analisados e impondo novas escalas de produção), outras questões passaram a ser consideradas, enfraquecendo a causalidade inversa entre concentração e desempenho econômico. A questão da inovação tecnológica é levantada por Koch (1980), segundo o qual é justamente nas estruturas mais concentradas que as inovações surgem em maior quantidade e velocidade.

Desta forma, as inovações surgem não somente porque as firmas estão atrás dos lucros monopólicos ${ }^{83}$, como também porque é através dos monopólios ou oligopólios que as firmas podem ser grandes o suficiente para investir os excedentes em pesquisa $\mathrm{e}$ desenvolvimento, já que diluem seus custos entre os diversos projetos de pesquisa em andamento.

${ }^{83}$ Conforme Farina (1994. p. 85) "é para deixar de produzir commodities de baixa margem de lucro e produzir especialidades que as empresas investem em pesquisa e desenvolvimento". 
A alternativa para garantir o bem estar geral, dadas as dificuldades de aplicação da legislação antitruste no controle da concentração do mercado, é o controle sobre a conduta dos agentes. São identificadas três formas de conduta indesejáveis: prática de preços abusivos, prática de preços predatórios e formação de cartel.

Os preços abusivos, que podem ser praticados por firmas monopolistas (ou oligopolistas agrupados em cartéis), devem ser controlados de forma a aumentar o bemestar da sociedade (mesmo para monopólios naturais, é possível regulamentar o nível de preços de forma a permitir o maior nível de produção possível, compatível com a permanência da empresa no mercado).

A dificuldade encontrada sobre o controle dos preços abusivos é a comparação com o preço do mercado competitivo, o qual supõe-se não existir, já que se está analisando um mercado concentrado. Embora a comparação possa ser feita com preços praticados em outros países, não é uma forma isenta de distorções, dificultando o processo.

A prática de preços predatórios é aquela na qual a firma realiza prejuízos durante o tempo necessário para eliminar os concorrentes, de forma a reduzir a competição do mercado. Normalmente está associada a uma pratica de subsídios cruzados (se é uma firma multiproduto ou faz parte de um conglomerado), de forma a financiá-la.

Segundo Farina (1994, p.87), nenhum arranjo contratual ou conduta (franquias, vendas casadas, etc.) deve ser considerado anticompetitivo sem uma análise mais rigorosa, devendo ser separados o "vigor de uma concorrência legítima das práticas predatórias". Portanto, sempre deve ser verificado se não existem ganhos de eficiência e de economias dos custos de transação que justifiquem a escolha. A formação de cartéis será analisada a seguir.

\subsubsection{Os acordos entre as empresas, as fusões e os cartéis}

Desta forma, em relação à formação de cartéis, diversas questões devem ser consideradas. Conforme Best (1990), a cooperação entre as firmas ou os cartéis de 
estabilização não devem ser vistos somente como forma de conseguir poder de mercado (embora normalmente o seja), mas também como forma de promover o desenvolvimento de longo prazo de um setor.

Os acordos entre as empresas, fusões e cartéis portanto, podem e devem ser aceitos quando são estabelecidos objetivando a racionalização da produção ou as reduções negociadas da capacidade produtiva (para evitar a concorrência predatória). Porém, segundo Best (1990), os cartéis ou qualquer outro tipo de acordo devem ser estabelecidos por período limitado de tempo e seguindo a orientação de uma política industrial, visando o desenvolvimento de longo prazo do setor.

As ações cooperativas podem ser comerciais e/ou industriais e também podem ser horizontais ou verticais. A cooperação horizontal (entre as firmas rivais do mesmo setor) é um importante fator de competitividade setorial, quando existem externalidades significativas nas atividades produtiva e inovativa, e sustenta a vantagem competitiva de todo o distrito industrial. A cooperação vertical refere-se àquela ao longo da cadeia, e é importante para melhorar a capacidade do sistema para responder à mudanças no ambiente legal, novas restrições de fornecedores, novas tecnologias, etc.

Portanto, conforme Best (1990, p. 17) ..."as firmas não apenas competem mas podem cooperar para fornecer serviços comuns, para estabelecer as regras do jogo de mercado ou para estabelecer as estratégias de investimentos complementares". O autor cita exemplos de cooperação entre as firmas na Alemanha (onde os cartéis promoveram o avanço tecnológico), na "terceira" Itália (ilustra com os consórcios financeiros que permitiram que pequenas firmas tivessem acesso ao mercado de capitais para obtenção de empréstimos, e com os consórcios de marketing para as empresas de mobília e decoração), e no Japão (onde as associações dos cientistas e engenheiros difundiram métodos estatísticos de controle de qualidade entre as indústrias japonesas).

Por outro lado, o autor reconhece que a cooperação entre as firmas pode, tal como prediz a teoria econômica tradicional, prejudicar o desempenho do setor. $O$ desafio é estabelecer meios de cooperação que gerem benefícios comuns para as firmas envolvidas sem prejudicar o desempenho econômico, o que se torna verdade quando a 
cooperação é o resultado de uma resposta a uma pressão, competitiva, causada, por exemplo, por uma rápida mudança tecnológica.

Portanto, a interdependência entre as firmas deve ser sustentada por uma base institucional, pública ou privada, que desenvolva a identidade coletiva e evite as ações oportunistas dos "free-riders", ou seja, deve haver incentivos à cooperação.

\subsubsection{Política industrial: falhas intertemporais de mercado}

A promoção de algumas indústrias nascentes, para as quais exista probabilidade razoável de lucratividade no longo prazo, era tradicionalmente o argumento utilizado para a adoção das políticas industriais. Neste caso, promovia-se o setor escolhido através de subsídios governamentais temporários, necessários, por exemplo, para enfrentar as economias de escala, que tornam não competitivas as operações nos estágios iniciais de funcionamento das firmas, ou para lidar com algum tipo de barreira que dificultasse sua entrada no mercado. Além destes, a política industrial também era um instrumento utilizado para eliminar a competição internacional a fím de se estimular a produção doméstica.

Conforme Farina et al. (1997), atualmente as discussões sobre política industrial indicam que na sua nova versão já não se trata mais de proteger as indústrias nascentes, e sim de identificar as necessidades de política que permitam que as indústrias das nações já desenvolvidas mantenham sua competitividade frente a concorrência externa.

Ou seja, procura-se analisar os determinantes da competitividade das nações, implicando no reconhecimento da importância dos ganhos de escala e escopo envolvidos, e na capacidade de promover atividades de pesquisa e desenvolvimento, justificando a existência das grandes corporações.

Porém, segundo Farina et al. (1997), ao mesmo tempo que a eficiência e o vigor do progresso tecnológico são objetivos da política industrial atual, estas questões implicam na aceitação de setores oligopolizados, com conseqüentes problemas associados ao poder de mercado a eles conferido. 
Desta forma, nesta nova versão de política industrial, a fim de enfrentar a concorrência externa, procura-se tornar determinados setores mais competitivos através justamente do aumento de sua concentração (estimulando fusões e certas práticas cooperativas entre os agentes), o que pode tornar-se conflitante com a política antitruste.

\subsubsection{As falhas de governo}

O debate sobre a intervenção estatal faz emergir outra questão: a dualidade entre as falhas de mercado e as falhas de governo, já que o Estado e as agências reguladoras nem sempre operam com a eficiência esperada. Desta forma, as falhas de mercado legitimam a intervenção do governo, por sua vez, as políticas ou as falhas do governo levam a uma reavaliação do seu papel.

Em relação às falhas governamentais, Coase (1964) salienta que normalmente os economistas desviam-se da principal questão que é como os arranjos alternativos realmente funcionam na prática, ou seja, não se pode esquecer que ) para se lidar com as falhas de mercado está se escolhendo entre dois arranjos sociais (o mercado ou as agências governamentais), que são ou mais ou menos falíveis.

O autor considera que algumas falhas de mercado (especificamente a informação imperfeita) são possíveis de serem solucionadas pela redefinição dos direitos de propriedade. Segundo o autor, as externalidades emergem quando os direitos de propriedade não estão bem definidos, porque eles servem de base para as negociações dos agentes. Desta forma, se os direitos de propriedade estão claros - e este é um papel importante que cabe ao governo - não existem externalidades e os mercados operam eficientemente.

Coase (1960) considera muito importante o papel das negociações privadas (barganhas) como modo de se conseguir uma eficiência maior para lidar com os problemas de externalidades, na ausência de custos de transação ${ }^{84}$. Conforme o teorema

\footnotetext{
${ }^{84}$ Segundo Noll (1989) os "custos de transação" neste contexto têm um significado geral: incluem além dos custos de negociar os contratos, os custos de ambas as partes para se preparar para a negociação. No caso de externalidades ambientais, eles incluem os custos de organizar os grupos que sofrem o problema para a negociação conjunta.
} 
de Coase (1960), uma alocação ótima de recursos sempre pode ser conseguida através das forças de mercado, se a informação é perfeita e não existirem custos de transação.

Contudo, a eficiência dos contratos privados requer informação perfeita e a ausência de custos de transação, implicando em um número limitado de agentes envolvidos na transação. Em situações onde existam um grande número de agentes e a informação seja imperfeita, esta pode não ser a melhor alternativa para lidar com as falhas de mercado.

Dada a aplicação limitada da negociação entre os agentes em casos de externalidades, a alternativa da intervenção governamental, mesmo sujeita às falhas, não pode ser desconsiderada quando se objetiva alcançar a produção eficiente. Existem situações em que a negociação direta entre as partes se mostra mais eficiente e também aquelas que requerem a aplicação de taxas e subsídios para se corrigir as falhas de mercado.

Petit (1995), ao tratar das falhas de governo, refere-se às contribuições da "nova economia política" ${ }^{, 85}$ que são úteis para explicar as ações tão freqüentes dos governos, que se propõem a servir os interesses públicos mas acabam servindo aos interesses privados. Elas também ajudam a entender as possibilidades da generalizada corrupção dos agentes públicos.

Ao expor as idéias dos autores da "nova economia política", Petit (1995, p.448) inicia com a teoria da regulamentação de Stigler $(1970)^{86}$, segundo a qual "Como regra, a regulamentação é conseguida pela indústria e é operada principalmente em seu benefício", indicando que mesmo que a regulamentação pretenda servir aos interesses públicos, ela freqüentemente atende aos interesses privados.

Outro problema levantado por Petit (1995) é o custo da organização, citando o conceito do free-rider, que é um agente que se beneficia das ações coletivas, mas que evita pagar por elas. Como consequiência deste comportamento, são necessárias várias

\footnotetext{
${ }^{85}$ O autor cita Stigler (1970), Olson (1965), Krueger (1974) e Buchanan e outros (1980).

${ }^{86}$ STIGLER, G. J. Director's Law of Public Income Redistribution. Journal of Law and Economics, 13,1 10, April 1970.
} 
ações por parte das empresas e do governo para minimizar os efeitos das ações destes agentes.

Desta forma, o autor conclui que as definições de políticas (incluindo as próprias decisões do Banco Mundial) são freqüentemente resultado das diversas pressões conflitantes, que surgem devido a existência das fallhas de mercado e das falhas governamentais.

Por outro lado, embora de uma forma geral sejam reconhecidas as falhas inerentes à intervenção governamental, e a necessidade de reavaliação de suas ações, existem suficientes falhas de mercado, demandas por bens públicos, por regulações, e externalidades, que fazem com que o governo continue tendo um papel importante a desempenhar.

\subsubsection{As associações de interesse privado}

Farina et al. (1997) salientam que na literatura normalmente são consideradas apenas duas organizações alternativas - o mercado e o Estado - cabendo ao último a responsabilidade de regulamentação. Porém, conforme os autores, outras organizações, tais como associações, sindicatos e a própria firma, têm diferentes incentivos para tratar as falhas de mercado, cuja eficiência relativa depende do tipo de imperfeição existente.

Desta forma, a existência de falhas de mercado e de governo podem levar organizações de interesse privado a terem importantes funções de coordenadores de certas atividades. Os autores salientam que bens ou serviços com características de bens públicos, de gerarem externalidades ou apresentarem problemas de informação imperfeita, ao invés de serem providos pelo Estado, podem apresentar vantagens se fornecidos pelas associações de interesse privado.

As vantagens relacionam-se à continuidade da ação, que não está sujeita à troca periódica de governos; ao maior conhecimento que as associações têm do setor e dos seus problemas; e, à maior agilidade para tomar as decisões e implantar as políticas. 
Conforme Stigler $(1988)^{87}$, citado por Saes (1998), as formas de ação das associações podem ser de dois tipos: as tradicionais e as pró-competitivas. Dentro da primeira categoria estão aquelas ações que visam a busca do lucro extra econômico ${ }^{88}$, tais como: funcionar como interlocutor junto ao Estado; de forma a assegurar posições estáveis e lucros de monopólio; conseguir subsídios diretos à produção; controlar a entrada de novas firmas; políticas que afetem a as indústrias de bens substitutos e complementares; controle administrativo de preços.

Por sua vez, as ações pró-competitivas das associações referem-se formulação de políticas setoriais visando estabelecer estratégias conjuntas buscando busca de eficiência.

Saes (1998) salienta que o papel das associações de interesse privado na história da política pública brasileira se alterou com o processo de desregulamentação iniciado nos anos 90. Se anteriormente as funções mais características das mesmas eram a negociação dos preços controlados pelo extinto Conselho Interministerial de Preços (CIP) e ações de lobby junto ao Estado, atualmente elas têm um papel de coordenação importante a desempenhar, de forma a aumentar a eficiência e competitividade dos sistemas produtivos.

\subsection{A Nova Economia das Instituições}

Os diferentes arranjos contratuais estabelecidos entre os agentes da cadeia sucroalcooleira, e suas alterações decorrentes do processo de mudança institucional que o setor está atravessando, são analisados pela ótica da Nova Economia das Instituições (NEI), utilizando principalmente a vertente da Economia dos Custos de Transação, de Oliver Williamsom (1985), complementada pelas idéias de Douglas North (1990), sobre o papel das instituições no desenvolvimento econômico.

\footnotetext{
${ }^{87}$ STIGLER, G.J. The theory of economic regulation. In: STIGLER G. J. (ed.) Chicago studies in political economy. Chicago: The University of Chicago Press, 1988. p.209-223.

${ }^{88}$ O lucro econômico difere do lucro contábil por considerar os custos de oportunidade dos recursos envolvidos.
} 
Dentro da Nova Economia das Instituições distinguem-se, conforme Carruthers \& Kydd (1997) duas vertentes principais: "a escola dos custos de transação", exemplificada pelos influentes trabalhos de North (1990) e Williamson $(1985,1991)$, e a "escola da informação imperfeita", caracterizada por Stiglitz (1988), sendo dada ênfase neste trabalho à utilização da primeira vertente. A seguir, faz-se uma breve apresentação dos trabalhos de Williamsom (1985) e de North (1990), os quais são usados para a análise de algumas relações encontradas no setor sucroalcooleiro.

\subsubsection{A Economia dos Custos de Transação - Williamsom (1985)}

$\mathrm{Na}$ Economia dos Custos de Transação a firma é vista como um "nexo de contratos" que disciplinam as transações, entendidas como "as transformações de um produto através de interfaces tecnologicamente separáveis" (Williamson, 1985, p.1). Desta forma, adota-se uma visão contratual da firma, e a unidade analítica passa a ser a transação.

Quando uma firma procura insumos necessários à elaboração de seus produtos, pode optar por diferentes formas de transação: comprá-los diretamente no mercado, produzí-los ela mesma ou optar por formas mistas de fornecimento (parcerias, arrendamentos, etc.). Do mesmo modo, ao vender seus produtos, pode vendê-los a um distribuidor que se encarrega de toda a operação, até que o produto chegue ao consumidor final, pode ela mesma se responsabilizar por todo o processo - fazendo o transporte, a distribuição, e tendo seus próprios pontos de venda - ou ainda optar por formas intermediárias entre estes dois modos.

Conforme a Economia dos Custos de Transação, a decisão sobre qual o modo mais eficiente de transacionar seus insumos e produtos vai além das estratégias empresariais que buscam reduções dos custos de produção envolvidos, devendo considerar outros custos - os custos de transação - que são aqueles decorrentes de fazer o sistema econômico funcionar, e que surgem ao se utilizar o sistema de preços como alocador de recursos em um ambiente onde não existam as condições vigentes em um mercado em concorrência perfeita. 
Arrow (1969) faz uma analogia entre os custos de transação e a força de atrito dos sistemas mecânicos: enquanto as perdas não consideradas nos modelos da física clássica (decorrentes da hipótese de não haver fricção) podem ser facilmente mensuradas por instrumentos de laboratório, aquelas decorrentes de se utilizar o sistema de preços como alocador de recursos, em um ambiente não competitivo, não são tão facilmente quantificadas, mas tais como as das forças de atrito, implicam em perdas e devem, portanto, ser consideradas.

Portanto, a escolha entre os diversos modos de se governar uma transação, ou seja, entre as diferentes formas de governança, considera a decisão entre fazer (produzir o bem sob estrutura hierárquica e administração própria), comprar (usar o mercado), ou adotar formas híbridas entre estes dois extremos, predominando a forma mais eficiente, que é aquela que minimiza não somente os custos de produção como também os custos de transação envolvidos.

\section{- As dimensões das transações: a especificidade dos ativos, a incerteza e a frequiuência}

Segundo Williamson (1985) as transações apresentam certas dimensões relacionadas à especificidade dos ativos envolvidos, à incerteza, e à freqüência das transações ${ }^{89}$, que, somadas ao pressupostos comportamentais da teoria (racionalidade limitada e comportamento oportunista), definem as formas organizacionais mais eficientes (governança via mercado, via formas híbridas ou via forma hierárquica).

A especificidade dos ativos refere-se "ao grau no qual o ativo pode ser reempregado em usos alternativos e por usuários alternativos sem sacrifício de seu valor" (Williamson,1996, p.105), ou seja, é o quanto aquele investimento é específico para aquela transação e qual o custo envolvido em sua realocação. Ativos específicos são reempregados com perda de valor.

\footnotetext{
${ }^{89}$ Conforme Furquim (1996), complementarmente ao atributo freqüência, Milgom \& Roberts (1992) propõem o atributo duração, para captar além da repetição, a intensidade com que a transação se manifesta; ao atributo incerteza, os autores adicionam complexidade, sendo que estas mudanças (dentre outras apresentadas) não alteram a essência da dimensionalização proposta por Williamson (1985).
} 
Williamson (1996, p. 105) distingue seis tipos de especificidade de ativos: locacional (refere-se à distância entre as firmas de uma mesma cadeia produtiva, que implica em diferentes custos de armazenamento e transporte), física (a especialização do ativo necessária para a produção de um componente), humana (necessidade de investimentos em capital humano específico para uma atividade), especificidade de marca (investimentos feitos na marca do produto); ativos dedicados (investimentos realizados para um cliente específico, sem uso alternativo); e, especificidade temporal (relacionada ao tempo durante o qual a transação se processa, sendo importante em negócios envolvendo produtos perecíveis).

Conforme aumenta-se o nível de especificidade dos ativos, maior a dependência entre as partes, impondo riscos adicionais e aumento dos custos no processo de renegociação, aumentando, desta forma, os custos de transação. Nestes casos, o uso do mercado torna-se ineficiente, privilegiando as relações hierárquicas

Desta forma, o nível de especificidade de ativos pode criar uma dependência bilateral entre os agentes, impondo riscos adicionais nos contratos. Por sua vez, ativos não específicos têm facilidade de aplicação alternativa: neste caso nẩo existe dependência entre os agentes da transação e o uso do mercado toma-se eficiente.

Furquim (1996) distingue ativo específico do conceito de sunk-cost, salientando nem sempre um sunk-cost é específico a uma transação (embora freqüentemente o seja). O conceito de sunk-cost refere-se aos custos fixos incorridos e irrecuperáveis num processo produtivo: se a compra de uma máquina implicar na impossibilidade de vendêla para outra atividade, ela representa um ativo específico e um sunk-cost; porém, se os gastos forem, por exemplo, com capacitação técnica, embora sejam gastos irrecuperáveis (sunk-costs), podem ser empregados em outras transações, não sendo portanto específicos aquela transação.

Outra característica da transação é a incerteza, e está relacionada às dificuldades inesperadas encontradas nas mesmas, decorrentes do desconhecimento dos possíveis eventos futuros e do comportamento estratégico dos agentes envolvidos nas transações. 
A forma organizacional mais eficiente de se governar uma transação depende do grau de incerteza inerente a ela.

Conforme Williamson (1996, p.116), os diferentes mecanismo de governança são mais ou menos sujeitos aos efeitos das variações inesperadas das transações, embora a eficácia de todas as formas possa se deteriorar devido aos distúrbios ocorridos.

Neste sentido, o modo de governança híbrido (por exemplo um contrato de longo prazo) é o mais susceptível a eles, já que as adaptações necessárias devido às mudanças não podem ser feitas unilateralmente neste modelo (diferentemente do caso das transações via mercado ou via hierárquica), envolvendo nova negociação entre as partes, requerendo o consenso de ambas. Desta forma, a incerteza é uma dimensão da transação que também deve ser considerada na escolha da forma mais eficiente de se governar uma transação.

A terceira dimensão da transação a ser analisada é a sua freqüência, que também é uma característica importante na definição do mecanismo de governança eficiente. As transações podem ser ocasionais ou recorrentes. As transações ocasionais (que ocorrem pontualmente, com baixa repetição) normalmente ocorrem via mercado, já que não seria eficiente se desenhar um contrato para se precaver de ações oportunistas (a não ser no caso de altamente específicos ou dedicados, que podem requer $o$ estabelecimento de contratos mesmo em transações pontuais).

As transações recorrentes, que acontecem com relativa frequiência, têm seus custos (inerentes à formulação dos contratos, coleta de informações, monitoramento) diluídos entre as diversas transações. Desta forma, para as transações recorrentes, os contratos de longo prazo podem ser mais eficientes do que a utilização do mercado.

Por outro lado, conforme Furquim (1996), a transação recorrente também possibilita que as partes se conheçam melhor, reduzindo a incerteza da transação, criando entre as partes um compromisso confiável (credible commitment), visando a continuidade da relação. Desta forma, a perspectiva de continuidade da relação reduz a probabilidade do comportamento oportunista, que pode acarretar na interrupção da mesma: quando o custo do comportamento oportunista for maior que os ganhos de se 
manter a relação, não existe incentivo para o rompimento dos contratos, e elas podem ser governadas sem necessidade de arranjos contratuais complexos.

Em síntese, ao analisar os custos de transação envolvendo uma troca, três dimensões principais das transações devem ser consideradas: a especificidade dos ativos envolvidos, a incerteza e a freqüência das mesmas.

\section{- Os pressupostos comportamentais: racionalidade limitada e oportunismo}

Em relação aos pressupostos comportamentais assumidos por Williamson (1985): racionalidade limitada (decorrentes da capacidade limitada dos agentes em absorver e processar as informações) e comportamento oportunista (que considera que os participantes, em algum momento, adotarão comportamento oportunista), parecem ser mais condizentes com a realidade do que a hipótese da racionalidade "total".

O pressuposto da racionalidade limitada implica na impossibilidade dos agentes de construir contratos completos, não por negar o comportamento racional dos mesmos e sim, porque a intenção de ser racional não implica em consegui-lo ser, já que existe a impossibilidade de se prever todos os estados futuros do ambiente.

Desta forma, a impossibilidade de prever todas as condições futuras de uma transação faz com que os contratos sejam necessariamente incompletos, o que leva os agentes a incluir salvaguardas contratuais (já que, mesmo limitadamente, eles são racionais e sabem da necessidade de adaptações e negociações contratuais ex-post), que permitam lidar com alterações inesperadas, o que aumenta os custos de transação.

Furquim (1996) salienta que embora os conceitos de racionalidade limitada e incerteza sejam freqüentemente confundidos, existe uma diferença entre eles: enquanto o primeiro refere-se a uma característica do indivíduo, o último é do ambiente, ou mais especificamente, da transação ${ }^{90}$.

\footnotetext{
${ }^{90} \mathrm{O}$ autor exemplifica com o jogo de xadrez, onde se conhecem as regras, os lances anteriores e os lances possíveis, ou seja não existe incerteza. Porém a limitação à racionalidade implica na impossibilidade da solução de problemas demasiadamente complexos, já que o ser humano tem limites em sua capacidade para lidar com problemas complexos, mesmo quando a informação é plena e sem custos.
} 
A hipótese do comportamento oportunista por parte dos agentes considera que os mesmos, em algum momento, adotarão comportamento oportunista, sendo necessário estabelecer mecanismos de fiscalização e controle ou mecanismos de incentivos para se controlar este eventual tipo de comportamento, sendo que ambos implicam em custos de transação adicionais. Desta forma, a existência de comportamentos oportunistas pode levar à escolha de formas hierárquicas ou híbridas de forma a minimizá-los, sendo que em alguns casos é necessária a aplicação de mecanismos de monitoração e controle/incentivo.

O comportamento oportunista pode ocorrer na fase pré-contratual, ou seja, antes da elaboração dos contratos, devido a uma das partes possuir algum tipo de informação prejudicial à outra parte e desconhecida por esta (já que se a informação fosse de conhecimento de ambas, a relação contratual poderia não ocorrer ou ocorreria em outras bases). Este tipo de comportamento é chamado na literatura de seleção adversa.

Portanto, a questão principal envolvida é a adesão ou não de determinada transação. Conforme Farina et al. (1997) se num mercado com bens de diferentes qualidades, está informação for disponivel somente por uma das partes, ele torna-se ineficiente, na medida em que os produtos de melhor qualidade tendem a ser excluídos devido ao seu preço mais alto (como os consumidores não têm como avaliar a qualidade do bem, ele compara o preço do bem com a qualidade esperada, optando em pagar preços menores por bens que eles imaginam ter a mesma qualidade).

Por sua vez, quando o comportamento oportunista devido a uma assimetria de informações decorre do uso da informação adicional na fase pós-contratual, ele é chamado de risco moral (moral hazard).

Os efeitos das hipóteses de racionalidade limitada e do oportunismo estão alinhados, ou seja, dada a dificuldade de se desenhar contratos completos, surge a necessidade de se incluir salvaguardas contratuais - que garantam a continuidade do contrato - e mecanismos de monitoramento e controle, assegurando que o estabelecido nos contratos será o efetivamente seguido. Decorrem daí custos adicionais: custos de 
transação "ex-ante" - relacionados às salvaguardas contratuais - e custos "ex-post", relacionados ao mecanismo de monitoramento e controle.

Desta forma, considerando os atributos das transações e os pressupostos comportamentais, estabelecem-se os custos de transação que, conforme dito anteriormente, correspondem ao custo de fazer o sistema econômico funcionar, em ambiente de incerteza, complexidade organizacional e oportunismo dos agentes.

São os custos "ex-ante" de preparar, negociar e salvaguardar um acordo, bem como os custos "ex-post" dos ajustamentos e adaptações que resultam quando a execução de um contrato é afetada por falhas, erros, omissões e alterações inesperadas. Tais custos somam-se aos custos de produção neoclássico, e fazem com que a firma não seja mais vista como uma mera função de produção e sim, conforme já salientado, como um "nexo de contratos".

Portanto, os ganhos advindos da escolha das estruturas de governança mais eficientes podem ser considerados como ganhos de eficiência tão importantes quanto os tecnológicos. Os contratos não convencionais (integração vertical, franquias, dentre outros), passam a ser vistos como formas de aumentar a eficiência (enquanto redutoras dos custos de transação, na presença de especificidade de ativos importantes), e não somente como aumento de poder de monopólio, abrandando-se as restrições existentes na legislação antitruste.

A Economia dos Custos de Transação permite analisar as formas como os agentes econômicos organizam suas transações - desde as alianças estratégicas entre os grandes grupos, até as relações envolvendo pequenos e médios participantes da cadeia produtiva - considerando fatores relacionados aos ativos envolvidos na transação.

Por outro lado, existem, conforme citado por Masten (1994), algumas barreiras na aplicação prática da referida teoria, tais como as fontes de dados e as questões de mensuração. As séries econômicas normalmente fornecem preços e quantidades, e as informações requeridas para testar as hipóteses da Economia dos Custos de Transação referem-se "...às formas organizacionais prevalescentes, às características das transações, ao nível de incerteza associado à transação, à complexidade dos produtos e processos, e 
a extensão na qual os ativos necessários à produção são específicos para aquela relação particular" (Masten, 1994, p.67).

Os dados normalmente utilizados ao se aplicar a Economia dos Custos de Transação são provenientes de entrevistas e questionários, que requerem cooperação dos agentes envolvidos no processo, o que nem sempre ocorre ${ }^{91}$.

Outra limitação da Economia dos Custos de Transação, que é levantada por Hubbard (1997), é que ela não provê ferramentas para examinar o impacto das instituições existentes sobre os contratos. Isto não é considerado um problema pelo autor quando o objetivo da análise é ajudar as firmas a tomarem decisões estratégicas dentro de um ambiente institucional estável e desenvolvido.

Contudo, se o ambiente institucional é instável ou está em desenvolvimento, isto se torna uma limitação importante. Instituições inadequadas aumentam os custos de transação, cujas conseqüências são custos de negociação contratuais e de "enforcement" mais altos, requerendo influência política e financeira para se tornarem efetivos.

\subsubsection{As Instituições - Douglas North}

A vertente de North (1991, p.97), evidencia o papel das instituições, assim por ele definidas: "Instituições são restrições construídas pelo homem que estruturam a interação social, política e econômica ...", sendo que as mesmas incluem qualquer forma de constrangimento criadas pelos agentes para moldar as interações humanas.

Desta forma, elas consistem tanto de restrições informais (sanções, tabus, costumes, tradições e códigos de conduta), como de regras formais (constituição, leis e direitos de propriedade), sendo que o maior papel das instituições numa sociedade é o de reduzir as incertezas através do estabelecimento de regras (nem sempre eficientes) para estruturar as interações humanas

Segundo North (1990), as instituições afetam a performance do desenvolvimento econômico devido aos seus efeitos sobre os custos de troca e de

\footnotetext{
${ }^{91}$ MASTEN (1994) apresenta outras considerações sobre os dados necessários e a mensuração dos custos de transação, além de alguns trabalhos que se utilizaram de proxis para se comparar os custos de transação em diferentes situações.
} 
produção. Juntamente com a tecnologia empregada, elas determinam os custos de transação e de produção.

Conforme o autor, existe uma relação entre os diferentes tipos de instituições e o desenvolvimento econômico, mostrando que, da mesma forma que algumas instituições promovem o desenvolvimento, existem outras que se constituem em obstáculos para o mesmo. Alterações no ambiente institucional (legislações, direitos de propriedade, códigos de ética) causam uma necessidade de adaptação dos contratos estabelecidos entre os agentes, já que alteram o funcionamento e a eficiência do sistema.

Carruthers \& Kydd (1997) salientam que o trabalho de North (1990) é uma fonte fértil de hipóteses sobre os fatores causais do subdesenvolvimento, sobre as funções e os efeitos das instituições, e dos determinantes da mudança institucional. Por outro lado, eles apontam que embora a Nova Economia das Instituições tenha se tornado uma influência importante na agenda de pesquisa sobre o desenvolvimento econômico, ela ainda é contida pelo número limitado de trabalhos empíricos e pela falta de um livro texto geral de amplo acesso.

Hubbard (1997) salienta que a microeconomia, tendo idealizado um mercado ideal, num ambiente de perfeita informação e comunicação, negligenciou os custos reais de se fazer os negócios: os atrasos, as incertezas, as barganhas, obstruções e malícias existentes, sendo que estes custos e as obrigações e direitos que as pessoas assumem para reduzi-los, são objetos de estudo da Nova Economia das Instituições.

Para o autor, no "coração" da economia institucional está o fazer, monitorar e fazer valer (enforcing) os contratos, sendo que a facilidade ou dificuldade em fazê-los, e os tipos de contratos feitos são determinados pelo nível e natureza dos custos de transação, subjacente ao qual está a extensão da informação imperfeita envolvendo uma transação.

Além disso, Hubbard (1997) salienta que a Nova Economia das Instituições (NEI) é caracterizada por duas proposições: (i) a natureza dos contratos é determinada pelas incertezas e garantias resultantes das condições de mercado e das instituições prevalescentes (direitos de propriedade, convenções, estrutura de autoridades); (ii) as 
instituições prevalescentes são alteradas pelas ações sociais respondendo às mudanças nas tendências dos preços relativos.

Os contratos, as leis e as convenções de uma sociedade podem tanto evoluir no sentido de reduzir os custos de transação, como ir em direção oposta. As instituições podem beneficiar um grupo mais que outros ou às custas de outros, e, como seu processo de mudança é difícil e lento, prendem a sociedade em determinado padrão histórico que pode ou não favorecer o desenvolvimento. Visto desta forma, o próprio desenvolvimento econômico é determinado pela extensão na qual as instituições do país favorecem o crescimento econômico sustentável (Hubbard,1997).

Alston (1998) salienta que alguns conceitos, tais como custos de transação, direitos de propriedade e compromissos confiáveis, são utilizados para determinar as ligações entre instituições e desempenho econômico.

Conforme o autor, as normas e leis da sociedade determinam os direitos de propriedade que os indivíduos possuem, tais como o direito de vender um ativo, o direito de usar e receber renda dele, ou o direito de legá-lo. Os direitos de propriedade fazem-se valer (are enforced) de três maneiras: os próprios indivíduos fazem valer seus direitos (por exemplo pondo chaves nas portas), através de sanções sociais (exclusão, ostracismo), ou pelo poder de coerção do estado (tal como a ação da polícia).

Os direitos de propriedade, juntamente com as normas existentes e a tecnologia, determinam os custos de produção (os custos de produção neoclássicos, associados com os custos de combinar os insumos para obter os produtos) e os de transação, que são os custos "invisíveis" da produção, incluindo os esforços de monitorar os trabalhos, coordenar os fatores físicos da produção, e monitorar o uso do capital físico e financeiro empregado no processo produtivo.

Tanto a tecnologia como os direitos de propriedade podem afetar os custos de transação de várias formas. A tecnologia, tanto na área agrícola quanto industrial, geralmente reduz, por exemplo, os custos de monitoramento (tal como através da padronização dos processos de produção, reduzindo a variação da produtividade 
marginal do trabalho), ou os custos de transação da coordenaçăo do trabalho (através do uso de informática nos diversos controles existentes na produção).

A figura 7 traz as relações entre as variáveis que afetam o desempenho econômico.

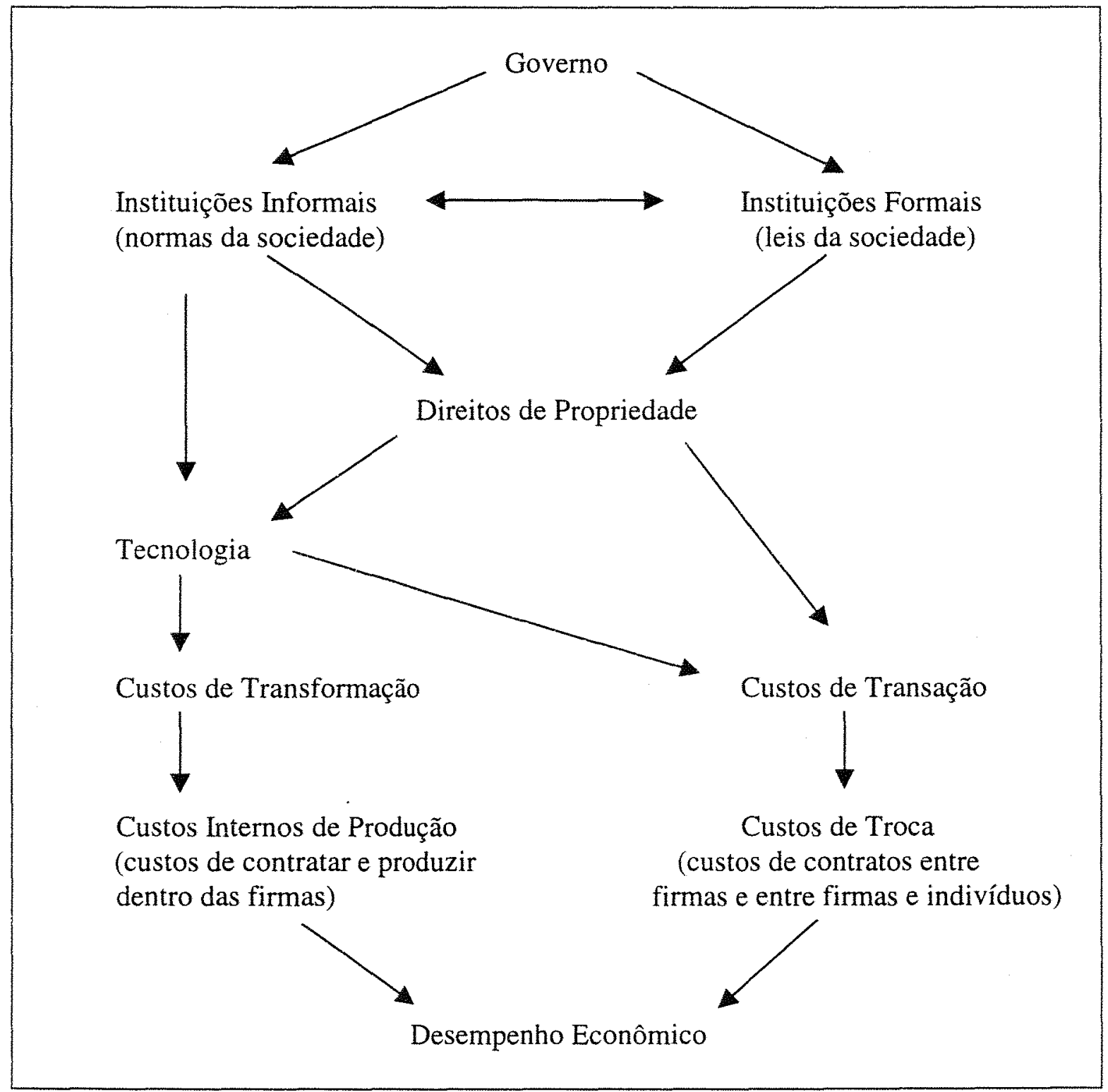

Figura 7 - Instituições e Desempenho Econômico (elaborada a partir de Alston, 1998)

Quanto à influência das normas e dos direitos de propriedade nos custos de transação, Alston (1998) exemplifica que se numa determinada cultura as pessoas 
realmente acreditam no trabalho sério (por tradição ou por incentivos passados), então os custos de monitoramento são menores. Da mesma forma, se a legislação de uma sociedade permite por exemplo, que se demitam facilmente os trabalhadores negligentes, os referidos custos também serão menores.

Os custos de transação incluem os custos de negociar e fazer valer os contratos. Em algumas sociedades as normas informais podem ser suficientes para garantir a negociação, da mesma forma que costumes de comunidades bem estabelecidos podem reduzir o comportamento oportunista, reduzindo os custos de transação.

As instituições podem reduzir também o potencial para comportamento oportunistas dos agentes: se as pessoas acreditam que existe uma corte de juízes honestos e uma legislação que garanta os direitos de propriedade, os custos de transação são reduzidos. Por sua vez, a ausência de uma corte confiável faz com que os custos de negociação sejam maiores, já que os contratos devem ter salvaguardas de tal forma que desestimule os indivíduos agirem oportunisticamente.

Desta forma, dados o conjunto de instituições de uma sociedade, os contratos entre os agentes serão feitos de tal forma a minimizar a soma dos custos de transação e de produção, os quais acabam influenciando o desempenho econômico.

Porém, Alston (1998) salienta que o ferramental conceitual apresentado na Figura 7 é basicamente estático, e não explica os determinantes das instituições nem como elas se alțeram. Para explicar a mudança institucional, ele evidencia que num processo de crescimento econômico existem ganhadores e perdedores. Os perdedores têm um incentivo para pressionar o governo para mudar as instituições para protegê-los das dificuldades do mercado, enquanto o estímulo dos ganhadores é no sentido de se preservarem as instituições presentes (ou mesmo tentar alterá-las para obter mais benefícios).

O autor classifica aqueles que fazem lobby para mudar as instituições e os que querem mantê-las como o lado da demanda da legislação. Estes grupos não tem poder para alterar a legislação, e suas reivindicações são filtradas pelas instituições 
governamentais (políticos, legisladores), que o autor chama de o lado da oferta da legislação.

O resultado final desta barganha entre o lado da oferta e da demanda são as regras formais e as leis de uma sociedade, sendo que alterações das forças do lado da demanda e da oferta resultam na mudança institucional.

Segundo Zylbersztajn (1995), o estudo de sistemas de agribusiness sob a ótica da Economia dos Custos de Transação deve, além de focalizar as transações como a unidade típica de análise, adicionar o ambiente institucional onde as transações são realizadas, já que mudanças no ambiente institucional podem acarretar mudanças de situações de equilíbrio. $\mathrm{O}$ autor propõe algumas variáveis relevantes que devem ser consideradas ao se analisar os custos de transação de um sistema típico de agroindústria, listadas na Figura 8.

\begin{tabular}{|c|c|c|}
\hline $\begin{array}{l}\text { Características } \\
\text { da Transação }\end{array}$ & & $\begin{array}{l}\text { - Especificidade de ativos } \\
\text { - Frequiência } \\
\text { - Incerteza }\end{array}$ \\
\hline $\begin{array}{l}\text { Aspectos } \\
\text { Contratuais }\end{array}$ & & $\begin{array}{l}\text { - Flexibilidade ex-post } \\
\text { - Desenho contratual } \\
\text { - Incentivos } \\
\text { - Arbitragem pública/privada } \\
\text { - Confiança } \\
\end{array}$ \\
\hline \multirow{2}{*}{$\begin{array}{l}\text { Instituições e } \\
\text { Organizações }\end{array}$} & Ambiente Institucional & $\begin{array}{l}\text { - Sistema legal } \\
\text { - Aspectos culturais } \\
\text { - Tradição e costumes } \\
\text { - Organizações políticas } \\
\text { - Aspectos internacionais }\end{array}$ \\
\hline & Ambiente organizacional & $\begin{array}{l}\text { - Bureaus públicos e privados } \\
\text { - Associações } \\
\text { - Organizações políticas } \\
\text { - Informações } \\
\text { - Tecnologia }\end{array}$ \\
\hline
\end{tabular}

Figura 8 - Variáveis Relevantes na Análise da Transação.

Fonte: Zylbersztajn (1995, p.176). 
Desta forma, além de se esperar que a estrutura de governança mais eficiente seja a minimizadora dos custos de transação, deve-se considerar que o ambiente institucional desenhado irá afetar os custos de transação envolvidos, alterando a eficiência do sistema. O autor salienta que a análise das variáveis relacionadas às características das transações definem as formas de governança eficientes, e daquelas relacionadas ao ambiente institucional indicam um vetor de parâmetros que influenciam as estruturas de governança minimizadoras dos custos de transação.

Para se aplicar este ferramental teórico no sistema sucroalcooleiro, (especificamente em dois elos principais do sistema, que são as relações entre fornecedores de cana e produtores de açúcar e álcool e entre os produtores e as distribuidoras de combustíveis), almeja-se primeiramente identificar as características das transações, os aspectos contratuais e as instituições e organizações existentes, e verificar como a desregulamentação irá influenciar os arranjos contratuais préestabelecidos.

\subsection{Determinantes Políticos dos Processos Decisórios}

Ao se estudar os determinantes políticos envolvidos nos processos de tomada de decisão, a partir dos arranjos institucionais estabelecidos para a implementação das políticas a serem adotadas, pretende-se identificar os atores sociais, suas estratégias e recursos de poder, e os mecanismos decisórios envolvidos.

A partir da política definida para o setor, algumas questões merecem ser analisadas, como a satisfação dos atores envolvidos, o cumprimento das metas estabelecidas, a sua viabilidade econômica e quem são os perdedores e os ganhadores, já que são elas que irão influenciar as futuras demandas por novas políticas.

Conforme Helfand (1994) a interação de quatro fatores são relevantes ao analisar-se as escolhas de políticas governamentais: o Estado, os grupos de interesse, a economia e o regime político.

Em relação aos regimes políticos, muitos autores argumentam que em regimes democráticos os grupos de interesse têm uma influência maior sobre as decisões políticas do que em regimes autoritários, porque os responsáveis pelas políticas são menos 
capazes de resistir às suas demandas, ou seja, nos regimes autoritários os objetivos nacionais definidos pelo autoritarismo estatal podem mais facilmente enfrentar as demandas particulares.

Porém, Helfand (1994) observa que a esta dicotomia simplificada entre regimes autoritários e democráticos devem ser acrescentados diversos outros fatores causais (como, por exemplo, fatores econômicos conjunturais), cujos efeitos alteram o resultado anterior.

Cita como exemplo o processo de democratização iniciado no Brasil nos anos 80 , que embora tenha facilitado a organização e participação de grupos de interesse ligados à agricultura, ocorreu simultaneamente a uma crise econômica, reduzindo a quantidade de subsídios agrícolas dramaticamente.

Conforme o autor, o processo de democratização encorajou mudanças que levaram a procedimentos de determinação de políticas agrícolas mais transparentes e consistentes, afetando não só como os grupos de interesse esforçam-se para influenciar nas decisões governamentais, como também nos resultados oriundos da política. Mas, ao mesmo tempo, a crise econômica, ao impossibilitar a viabilidade de créditos subsidiados, forçou o Estado e os grupos de interesse a procurar políticas alternativas, que moveramse numa direção de liberação de mercado.

Por sua vez, Lamounier (1994, p.3) ressalta que pelo menos três elementos devem ser considerados ao se analisar os determinantes políticos das políticas governamentais:

"(a) a "arena" decisória, isto é, a maneira pela qual o processo decisório é estruturado e condicionado pelo seu próprio objeto;

(b) o contexto institucional, vale dizer, os alinhamentos e influências que decorrem da natureza formal daquele processo, conforme se trate, por exemplo, de votação no Legislativo, de negociação incremental entre as agências 
burocráticas e grupos de interesse, de determinação imperativa e individual do presidente da República, etc.;

(c) o perfil dos atores relevantes, ou seja, os objetivos e recursos de poder de que dispõe as coalizões favoráveis e contrárias à política em questão."

Em relação às arenas decisórias, Lamounier $(1994)^{92}$ salienta que é possível identificar três grandes categorias de políticas públicas, e consequentemente de arenas de poder: as políticas de distribuição, de redistribuição, e de regulamentação.

Nas políticas de distribuição tem-se uma visão de curto-prazo, sendo que os recursos parecem ser ilimitados, já que seus benefícios podem ser desagregados e distribuídos em pequenas unidades. Desta forma, é difícil identificar os perdedores e os ganhadores, já que o mais influente pode ser atendido por uma nova desagregação do benefício. Como exemplo de políticas agrícolas distributivas o autor cita o crédito subsidiado e a equivalência-produto.

Por sua vez, as políticas redistributivas são aquelas que têm impacto direto sobre a distribuição da renda e riqueza entre as classes da sociedade, tais como políticas tributárias e programas de reforma agrária.

Já as políticas regulatórias, nas quais os recursos são considerados limitados, implicam em decisões de distribuição de custos e oportunidades para indivíduos e grupos, e pautam-se na existência de uma norma geral. Como exemplo o autor cita a concessão de um canal de televisão, a reserva de mercado para produtos e insumos agrícolas, proibição ou contingenciamento das exportações de produtos agrícolas, liberalização da importação de produtos agropecuários, isenção de ICMS para diversos tipos de produtos (produtos agrícolas exportados, produtos da cesta básica, insumos agrícolas), isenção de IPI de máquinas e equipamentos, definição dos produtos agrícolas cobertos por uma política de preços mínimos, etc.

\footnotetext{
${ }^{92} \mathrm{O}$ autor apoia-se no modelo de LOWI, T. American Business, public police, case studies and political theory. World Politics, v.16, p.767-715, 1964.
} 
Conforme o autor, nos modelos pluralistas e altamente competitivos usualmente utilizados nas análises da política americana, as políticas públicas são vistas como resultantes de um "paralelogramo de pressões", sendo que o autor salienta que somente no processo decisório envolvendo as políticas regulatórias os atores, tipos de conflito e locci de decisão tem as características propostas no modelo pluralista.

Em relação aos atores, Lamounier (1994) salienta que é importante identificar os objetivos perseguidos pelos diversos atores e quais recursos mobilizados para alcançá-los. Diferentes atores buscam bens diversos com variadas intensidades, sendo preciso identificar as vantagens e dificuldades que cada um encontra para atuar no sentido de sua preferência.

Conforme o autor, em qualquer análise de política pública o governo deve ocupar um papel central, porém não se deve considerá-lo como um ator único, pois também existem diferenças importantes em relação aos "bens almejados" entre os distintos segmentos do governo: Executivo e Legislativo, diferentes ministérios e níveis de administração, entre as diferentes agências públicas, que são essenciais para a análise.

Em relação aos grupos de interesse, Lamounier (1994) salienta que um recurso político de fundamental importância é o grau de organização dos mesmos, sendo importante identificar a maior ou menor facilidade que os grupos têm para organizar-se: grandes grupos têm problemas específicos de ação coletiva, já que enfrentam mais dificuldades em promover a organização e a atuação conjunta de todos os potencialmente interessados naquela ação.

Isto decorre principalmente dos problemas de "free-riding", ou seja, devido a tendência dos indivíduos em pegar uma carona nos benefícios resultantes da ação coletiva sem pagar os ônus correspondentes, que são tanto maiores quanto maior o tamanho dos grupos. Os grupos menores, por terem mais facilidade em se organizar e definir interesses exclusivos, teriam maior influência sobre as decisões políticas do governo. 
O autor salienta que os grandes grupos divergem entre si em relação às ações coletivas em função de sua localização espacial: os mais dispersos tem mais dificuldades em se organizar do que aqueles espacialmente concentrados.

Lamounier (1994, p.6) observa que para analisar os recursos de poder dos atores envolvidos, além da capacidade de organização dos mesmos, deve-se considerar outros atributos, situações ou instrumentos, tais como: "... capacidade de ameaçar os contendores com algum resultado indesejado, força organizada, acesso a informações privilegiadas, acesso privilegiado a agências públicas e a seus dirigentes, capacidade de estabelecer redes de alianças, influências, posição estratégica, legitimidade, estima externa", sendo que estes são recursos que dependem das arenas e do contexto dos processos decisórios.

Desta forma, ao se estudar as decisões políticas deve-se considerar os atores envolvidos e sua capacidade de influir (presente e futura), e os recursos de poder, positivos e negativos, que os mesmos têm para valer suas opiniões, que é uma das análises que se almeja fazer neste trabalho.

\subsection{MÉTODOS}

Foram realizadas 28 entrevistas envolvendo lideranças do setor sucroalcooleiro, dirigentes de usinas e de associações privadas, representantes dos fornecedores de cana, consultores do setor, congressistas e membros da burocracia pública, os quais, no atual quadro institucional, têm influência na determinação das políticas e decisões governamentais relativas ao setor.

As entrevistas foram realizadas no período de janeiro a abril de 1999, e seguiram alguns roteiros de perguntas (Apêndice 1), os quais apresentavam pequenas diferenças conforme o grupo de entrevistados (representantes de usineiros, de fornecedores, parlamentares e governo).

As perguntas dos questionários procuraram identificar, primeiramente, se os entrevistados consideravam que o afastamento do Estado deveria ser total ou parcial, as 
razōes apresentadas em cada caso, e qual seria então a nova forma requerida da ação estatal.

Além disso, procurou-se identificar as características do mercado de cana-deaçúcar, do açúcar e do álcool que pudessem indicar alguma de falha de mercado que justificasse uma ação por parte do governo, e também quais as melhores formas de se governar as transações existentes dadas as características das mesmas e do ambiente institucional encontrado.

Posteriormente buscou-se entender o processo da desregulamentação ocorrido, as causas e os responsáveis pelos diversos adiamentos, a fim de se identificar os atores e os recursos de poder envolvidos, e os efeitos de suas ações sobre as políticas setoriais resultantes.

Dentre as lideranças, procurou-se entrevistar as pessoas participantes do Comitê Consultivo do CIMA, sendo os mesmos representantes dos produtores de açúcar e álcool, dos fornecedores de cana, e um Senador da República. Da Câmara Técnica do CIMA foram ouvidos quatro consultores, e pelo governo a entrevista foi feita com a Diretora do Departamento de Álcool e Açúcar do Ministério do Desenvolvimento, Indústria e Comércio.

Em relação a escolha da amostra das indústrias, procurou-se torná-la a mais abrangente possível, dentro das limitações do trabalho. Cientes da existência de 324 fábricas, de vários portes, com diferenças regionais (com climas, relevos, e produtividades distintas), espacialmente distribuídas em diversas localidades (com problemas de logísticas particulares), com perfis financeiros e administrativos distintos, implicando, portanto, em diferentes custos de produção, de comercialização e níveis de eficiência, optou-se em utilizar alguns critérios.

Primeiramente considerou-se a existência de quatro "subgrupos" diferenciados em relação a aquisição de matéria-prima (especificamente cana-de-açúcar): o primeiro é aquele em que toda a cana é originada de fornecedores; no segundo existe uma parcela de cana própria e outra de fornecedores; o terceiro compõe-se de cana exclusivamente própria da usina; e no último a cana é proveniente de arrendamento de terra. Procurou-se 
com esta seleção verificar as diferenças e dificuldades relativas à implantação do novo modelo de remuneração da cana de açúcar (CONSECANA).

Além deste fato, procurou-se conversar tanto com representantes das usinas tradicionais (as já existentes anteriormente ao Proálcool), como das unidades oriundas do Proálcool, localizadas em regiões mais distantes (Mato Grosso, Oeste do Estado de São Paulo), como do Estado do Paraná, estado produtor relativamente novo e cuja produção está crescendo muito nos últimos anos. Em relação à região Nordeste, foram ouvidas lideranças do setor industrial e dos fornecedores de cana.

Em relação aos fornecedores, além do Presidente da Federação dos Plantadores de Cana do Brasil, foram ouvidos os presidentes das duas maiores associações de fornecedores de cana do Centro-Sul (Sertãozinho e Piracicaba), e da associação de Jaú.

As opiniões relativas ao setor ${ }^{93}$ de diversos parlamentares da Câmara dos Deputados, alguns dos quais também fazem parte do Comitê Consultivo do CIMA, foram colhidas na Audiência Pública Conjunta com a Comissão de Agricultura e Política Rural e de Economia, Indústria e Comércio sobre o Setor Sucroalcooleiro, realizada na Câmara dos Deputados, em Brasília, em 15 de abril de 1999.

Da referida Audiência Pública fizeram parte outros membros do governo, cujas ações são decisivas para o setor, dentre eles: Dr. Bolivar Barbosa Moura Rocha (Secretário Executivo do Ministério do Desenvolvimento, Indústria e Comércio) e Dr. David Zylbersztajn (Diretor Geral da Agência Nacional do Petróleo - ANP) ${ }^{94}$.

As pessoas entrevistadas estão relacionadas a seguir:

\section{Comitê Consultivo do CIMA:}

\footnotetext{
${ }^{93}$ Deve ser salientado que neste caso não foi seguido o roteiro das entrevistas utilizado com os demais entrevistados.

${ }^{94}$ Os demais participantes da mesa foram: Antônio Celso Cavalcante (Presidente da Federação dos Plantadores de Cana do Brasil - FEPLANA); Luiz Milton (Secretário Adjunto de Acompanhamento Econômico do Ministério da Fazenda); Gilberto Carvalho Tavares de Melo (Presidente do Sindicato da Indústria do Açúcar e do Álcool no Estado de Pernambuco - SINDAÇÚCAR); Gustavo Costa Maranhão (Presidente da Associação Brasileira da Indústria do Álcool - ALCO); Jorge Toledo Florêncio (Presidente do Sindicato da Indústria do Açúcar e do Álcool do Estado de Alagoas); José Luiz Perez Garrido (Secretário Executivo do Ministério das Minas e Energia); Ricardo Gusmão Dornelles (Coordenador do Comitê de Comercialização do Álcool Etílico Combustível); Sérgio Luiz Leite (Secretário Geral da Federação dos Trabalhadores das Indústrias Químicas e Farmacêuticas do Estado de São Paulo FEQUIMFA); e, Werther Annicchino (Membro do Conselho de Administração da COPERSUCAR).
} 
1. Antônio Celso Cavalcante de Andrade - Presidente da Federação dos Plantadores de Cana do Brasil - FEPLANA;

2. Gustavo Costa A. Maranhão - Presidente da Associação Brasileira da Indústria do Álcool (ALCO);

3. Jorge Toledo Florêncio - Presidente do Sindicato da Indústria do Açúcar e do Álcool do Estado de Alagoas;

4. Senador Jonas Pinheiro - Mato Grosso;

5. Werther Annicchino - Membro do Conselho de Administração da COPERSUCAR.

2. Câmara Técnica do CIMA:

6. Antônio de Pádua Rodrigues - Departamento de Planejamento e Economia UNICA;

7. Luiz Carlos Corrêa Carvalho - Superintendente UNICA;

8. Plínio Nastari - Presidente DATAGRO.

3. Representantes das Associações de Industriais

9. Honório Kytaiama - Superintendente SOPRAL;

10. Lamartine Navarro Jr. - Presidente SOPRAL;

11. Paulo Zanetti - CEPAAL;

12. Roberto Rezende Barbosa - Conselheiro SUCRESP, Diretor Vice-Presidente Tesoureiro UNICA;

13. João Carlos de Figueiredo Ferraz - Presidente do Conselho Deliberativo da Bolsa Brasileira de Álcool (BBA)

4. Representantes das Associações de Fornecedores

14. Francisco Paulo L. Brandão - Associação dos Plantadores de Cana da Região de Jaú (ASSOCICANA); 
15. José Coral - Presidente da Associação dos Fornecedores de Cana de Piracicaba (AFOCAPI) e da COPLACANA e, vice-presidente ORPLANA;

16. Dr. Ênio Roque de Oliveira - ORPLANA

17. Manoel Ortolan - Associação dos Plantadores de Cana do Oeste do Estado de São Paulo.

5. Produtores de Açúcar e Álcool

18. Carlos Diogo Motta Garcia - Cooperativa Agrícola de Produtores de Cana de Campo Novo do Parecis LTDA (COPRODIA) - MT;

19. José Pessoa de Queiroz Bisneto - Diretor Presidente - Grupo Econômico José Pessoa - MG, MS e SE;

20. Luis Gustavo Junqueira Figueiredo - Gerente Comercial - Usina Alta Mogiana - SP;

21. Marcos Ometto Gonçalves - Diretor Superintendente - Usina da Barra S.A. $\mathrm{SP}$;

22. Maurilio Biagi Filho - Companhia Energética Santa Elisa - SP;

23. Oscar Figueiredo Filho - Diretor Superintendente - Usina Alta Floresta SA PR e Usina Alta Floresta - SP;

24. Pedro Isamu Mizutani - Diretor Administrativo Financeiro - COSAN - SP;

25. Sérgiọ Simões Ometto - Diretor Presidente - Usina da Barra S.A. - SP;

26. Walter Rischbieter - Diretor Comercial - Usinas Itamarati S.A. - MT.

6. Representante do Governo (Burocracia Pública)

27. Elizabeth Seródio - Diretora do Departamento de Álcool e Açúcar do Ministério do Desenvolvimento, Indústria e Comércio

7. Parlamentares (Congressistas)

28. José Machado - deputado federal - PT 


\section{RESULTADOS E DISCUSSÃO}

Procurou-se sumariar tematicamente os principais resultados, levantados a partir das entrevistas realizadas. Dada a questão central da tese, que é até que ponto é possível o afastamento total do Estado deste setor, emergiram três grandes temas:

- se o afastamento não for total, qual o novo papel do Estado no setor sucroalcooleiro, determinado a partir da análise do novo ambiente institucional e das falhas de mercado existentes nos elos da cadeia produtiva, e dos objetivos de política pública a serem seguidos;

- quais as formas de transação dos insumos e produtos mais eficientes, considerando-se as características dos mercados de cana-de-açúcar, de açúcar e do álcool, e do ambiente institucional estabelecido após a desregulamentação e;

- a identificação dos atores e recursos de poder que influenciam o processo de desregulamentação e os destinos do setor.

Conforme comentado no capítulo 5, a discussão de cada tema é feita utilizandose um dos ferramentais teóricos apresentados anteriormente. Para se discutir o novo papel do Estado e a necessidade de regulamentação estatal nos elos da cadeia produtiva procurou-se identificar as falhas de mercado existentes, através das características dos mercados estudados e do ambiente institucional, apoiando-se na Microeconomia Tradicional.

Da mesma forma, as características dos mercados e do ambiente institucional foram usadas para identificar os modos mais eficientes de comercializar os insumos e produtos da cadeia produtiva, com base na Nova Economia das Instituições. 
Por sua vez, o processo de desregulamentação propriamente dito é discutido considerando algumas idéias de economia política, procurando-se identificar as arenas decisórias, os atores envolvidos e seus recursos de poder que influenciam as escolhas governamentais.

A seguir, a partir dos dados levantados, analisa-se as características do ambiente institucional e dos mercados de cana-de-açúcar, açúcar e álcool que indiquem a existência de falhas de mercado que possam evidenciar a necessidade de regulamentação estatal, e sintetiza-se a opinião dos entrevistados no tocante a intervenção estatal em cada um dos mercados. Também com base nas características dos mercados, procura-se identificar as formas mais eficientes de se transacionar os insumos e produtos dos mesmos.

Em relação ao grau de afastamento do Estado do setor sucroalcooleiro é interessante notar que a grande maioria dos entrevistados (aproximadamente 89\%) considera que não é possível que ele se retire totalmente.

Embora, conforme será visto a seguir, os argumentos apresentados para o afastamento parcial sejam bastante distintos, e o grau de interferência que cada um considera ideal também varie muito, apenas três entrevistados pensam que o Estado deva se retirar totalmente do setor. Mesmo assim, estes salientam que antes que o Estado saia, deixando que as forças de mercado atuem livremente, o problema da falta de competitividade do álcool em relação a gasolina deve ser solucionado através de um mecanismo tributário.

\subsection{As características dos mercados de cana-de-açúcar, de açúcar e do álcool e do ambiente institucional: as falhas de mercado e as formas requeridas da ação estatal e as estruturas de governança mais eficientes}

\subsubsection{O mercado de cana-de-açúcar}

Analisando primeiramente o mercado da cana-de-açúcar, cujas características serão usadas tanto para identificar as formas mais eficientes de transacioná-la, como também para analisar a existência de falhas de mercado, nota-se que há consenso entre a 
maioria dos produtores de cana, industriais, parlamentares e governo entrevistados no tocante a algumas características peculiares à sua produção, que a diferencia dos demais produtos agrícolas. Foram destacadas:

- Cultura de ciclo longo, sazonal: requer planejamento de longo prazo, com problemas de comercialização de curto-prazo;

- Perecibilidade: não é um produto armazenável; tem a época certa para ser colhida, não pode ser transportada a longas distâncias;

- Custo de transporte: inviabiliza transporte de longas distâncias, restringindo seu mercado.

Iniciando-se a análise com o modo mais eficiente de se transacionar a cana-deaçúcar, apoiamo-nos em Willamson (1985), procurando-se identificar o nível de especificidades dos ativos envolvidos (especificidade locacional, física, humana, e temporal), já que quanto maiores os níveis de especificidades dos ativos, maior a dependência entre as partes, tornando as relações hierárquicas mais eficientes para reger a transação.

Além disso, procura-se identificar as mudanças ocorridas no ambiente institucional com a desregulamentação, que conforme Zylbersztajn (1995), podem acarretar alterações em situações de equilíbrio.

Em relação à especificidades dos ativos envolvidos na transação, nota-se que o grau de especificidade locacional é alto, já que a distância entre as usinas e canaviais influi no custo de transporte, que é significativo dentre os custos totais, e impossibilita o transporte da cana-de-açúcar a longas distâncias.

A especificidade temporal também é importante, devido à perecibilidade da cana e ao problema da concentração do fornecimento de cana em determinadas épocas, fazendo que, sem mecanismos de incentivos adequados, a entrega concentre-se em períodos cujo teor de sacarose é mais alto (ocasionando excesso de oferta de cana nestes períodos e falta nos demais, dificultando o planejamento da mão-de-obra na colheita e o processamento da cana pela usina). 
Em relação a especificidade física existente, ela pode ser considerada alta tanto para os industriais como para os fornecedores. Para os primeiros, deve-se aos equipamentos das unidades industriais (moendas de cana, tanques de armazenamento de álcool, dentre outros) que destinam-se exclusivamente à produção de açúcar ou álcool a partir da cana-de-açúcar, com difícil realocação para outra atividade.

A dependência da unidade industrial em relação a cana de fornecedor será tanto maior quanto maior for a participação da cana de fornecedor em relação a sua capacidade de esmagamento, e quanto maior for o número de outras unidades industriais próximas "disputando" aquela matéria-prima.

Para os produtores de cana, embora os ativos disponibilizados para a produção (maquinários, terra) possam ser realocados para outras culturas, a partir do plantio ele fica "atado" à lavoura por pelo menos 5 anos. Pelo fato da cana-de-açúcar ser uma cultura de ciclo longo, o primeiro corte é feito somente um ano a um ano e meio após o plantio, e os significativos investimentos feitos para plantar, cultivar e tratar do canavial são recuperados, em média, após cinco cortes anuais.

Além disso, a cana-de-açúcar destina-se exclusivamente a ser vendida para usinas e destilarias, sem possibilidade de uso alternativo, fazendo com que o fornecedor precise ter uma garantia de poder entregar seu produto por este período que viabiliza o plantio.

Da mesma forma, a subordinação do fornecedor à usina dependerá do número de unidades industriais existentes numa distância cujo transporte da cana seja viável, e de quanto sua cana representa em relação à cana própria da usina.

Portanto, dadas as características dos ativos envolvidos na transação (tanto da matéria-prima como da produção industrial), fica caracterizada a existência de dependência bilateral entre as partes e espera-se, conforme Williamson (1985), que a transação de comercialização da cana seja feita através de relações hierárquicas: contratos de fornecimento entre os agentes, arrendamentos de terra pelas usinas, ou cana cultivada em terras próprias das usinas (implicando em imobilização de capital). Ou seja, 
a utilização do mercado (compras de cana-de-açúcar no spot) seria a forma menos eficiente de se negociar esta matéria-prima.

Nas últimas safras, estima-se que em São Paulo aproximadamente $70 \%$ da cana seja transacionada de forma hierárquica (terras próprias ou arrendamentos), sendo os restantes $30 \%$ oriundos de cana de fornecedor. Das canas de fornecedor, é interessante notar que, embora as altas especificidades encontradas, até a safra de 1998/99 existia uma pequena quantidade de contratos formais entre fornecedores e industriais, fato que pode ser explicado pelo ambiente institucional regulamentado, no qual o relacionamento entre as partes era regido pelo Estado, amparado na legislação que vigorava até então, o que impunha um compromisso entre as partes.

A existência do Estatuto da Lavoura Canavieira ${ }^{95}$, que disciplinou rígida e controladamente as relações entre fornecedores de cana e produtores, estabelecendo a forma e a fixação das cotas de fornecimento dos fornecedores junto às usinas, assegurava a moagem das canas pelas usinas e o seu recebimento pelas mesmas.

Além disso, a Lei № ${ }^{0} .870$, de 1965, que revigorou as disposições do Estatuto e estabeleceu a participação dos fornecedores na valorização dos estoques e o pagamento da cana pelo teor de sacarose, faziam com que a comercialização do produto estivesse legalmente regulamentada.

Porém, embora ainda vigentes, ao longo do tempo os rígidos dispositivos legais do Estatuto foram perdendo força diante da nova realidade, na qual os volumes produzidos cresceram exponencialmente a partir do Proálcool, sem que o IAA tivesse reajustado as cotas oficiais de açúcar, de álcool e consequentemente de cana.

Do mesmo modo, a participação do fornecedor valorização dos estoques estava vinculada à fixação das cotas mensais de comercialização do açúcar, que deixaram de existir; e o pagamento de cana pelo teor de sacarose é caracterizado por um ágio adicionado sobre um preço oficial, que também não existe mais desde $1^{\circ}$ de fevereiro de 1999.

\footnotetext{
${ }^{95}$ Decreto-Lei № 3855 , de 21/11/1941.
} 
Desta forma, é interessante notar que a mudança no ambiente institucional, iniciada com a Constituição Federal de 1988, e acentuada com a desregulamentação do setor, implicou em mudanças profundas no relacionamento entre as partes, principalmente quando se considera a falta de aplicabilidade da legislação existente.

Com a desregulamentação, surgiu a necessidade de se criar uma nova forma de relacionamento que pudesse substituir a ação estatal, dada a dependência bilateral entre estes agentes.

No Estado de São Paulo, uma parte das transações entre fornecedores de canade-açúcar e produtores de açúcar e álcool, já na safra 1998/99 (quando a expectativa da liberação de preços era prevista para maio de 1998), passou a ser assegurada por contratos firmados entre fornecedores e indústrias, a despeito da legislação então em vigor, que prorrogou a liberação dos preços para fevereiro de 1999. Os contratos baseiam-se no novo modelo de remuneração da cana-de-açúcar (CONSECANA), conforme visto anteriormente.

\subsubsection{O CONSECANA}

Em relação ao CONSECANA, as opiniões dos entrevistados divergiram bastante, não somente entre os fornecedores e os industriais, como dentro das próprias categorias.

$\hat{E}$ interessante verificar que em algumas regiões praticamente não existe cana de fornecedor, e portanto, pouco se discutem as questões inerentes ao CONSECANA. Este é o caso das regiões das destilarias do Proálcool $^{96}$, onde a cana é proveniente em sua maior parte de terras próprias das destilarias, já que os projetos de financiamentos das mesmas, na época do Proálcool, só eram aprovados mediante comprovação de posse da terra, de forma a garantir disponibilidade da cana-de-açúcar.

Da mesma forma, no Estado do Paraná existe pouca quantidade de cana de fornecedor, já que em sua maior parte elas são provenientes de terras de agricultores organizados em cooperativas (que montaram as usinas e destilarias), ou de terras

\footnotetext{
${ }^{96}$ Mato Grosso, Mato Grosso do Sul, Goiás e centro-oeste do Estado de Sāo Paulo.
} 
$\operatorname{arrendadas}^{97}$. Naquele Estado, o CONSECANA é considerado importante para se ter uma referência de preços da cana para ser usado nos arrendamentos.

Portanto, a adoção desta nova forma de remuneração da cana-de-açúcar, e todos os problemas e discussões inerentes à mudança, são mais característicos das regiões tradicionalmente produtoras (Estado de São Paulo e Nordeste).

$\mathrm{Na}$ categoria dos fornecedores de cana, percebeu-se que as opiniões divergiram dentro desta categoria: alguns são contra o modelo e outros acreditam que embora o modelo seja bom, ele não funciona sem arbitragem governamental.

Aqueles que são contra o modelo destacam dois motivos: o primeiro é porque acreditam que os preços resultantes para a cana atualmente, em decorrência dos níveis atuais de preços do açúcar e do álcool, não remuneram a atividade; depois por acharem que quando houver alta de preços destes produtos os mesmos não serão repassados aos produtores de cana-de-açúcar.

Desta forma, crêem que o modelo, além de precisar de mudanças nos parâmetros técnicos de forma a viabilizar a atividade agrícola, só funcionará com arbitragem governamental. Solicitaram ao governo, inclusive, que oficializasse, através de Medida Provisória, a definição de regras básicas entre o segmento de produção de matéria-prima e a indústria sucroalcooleira.

Ainda na categoria de fornecedores, outros entrevistados consideram o modelo conceitualmente justo, ao compartilhar tanto as perdas como os lucros, mas também acreditam que o mesmo requer regulamentação estatal que faça com que o modelo seja adotado por todos ${ }^{98}$, e que o contrato seja cumprido. Além disso, temem que a Câmara

\footnotetext{
${ }^{97}$ Segundo Paulo Zanetti, da ALCOPAR, das 28 empresas produtoras de açúcar e álcool existentes, 10 são cooperativas. Por exemplo, os 196 produtores associados da COROL são os donos da indústria; a cooperativa faz para os produtores um adiantamento para o custeio, industrializa a cana, e comercializa os produtos finais. Desconta os custos de produção, tira a margem para manter a indústria e distribui o restante.

98 Conforme um entrevistado, na região de Sertãozinho, em setembro de 1999, apenas uma das 20 unidades industriais existentes formalizou o CONSECANA via contratos. O restante das unidades industriais, embora esteja fazendo o pagamento utilizando o ATR, não o faz via contratos. As dificuldades para a formalização da negociação entre as partes decorrem tanto da parte das usinas como dos fornecedores.
} 
de Juízo Arbitral seja incapaz de solucionar eventuais conflitos, e que as pendências acabem na justiça comum, que por ser muito lenta é prejudicial ao fornecedor.

Dos problemas enfrentados na safra 98/99 que foram levantados pelos fornecedores entrevistados destacam-se ${ }^{99}$ : o não fornecimento da via do contrato do fornecedor, sendo que alguns fornecedores inclusive assinaram folhas em branco (caso contrário a usina não receberia a cana); e falta de pagamento (não foi cumprido o que estava no contrato). As razões citadas para tal comportamento foram:

- os fornecedores estão em sua maioria sem estrutura para o plantio, transporte, etc. (nos últimos anos as usinas se responsabilizavam por várias etapas do processo produtivo), dificultando a mudança para outra cultura e piorando sua condição de negociação com as usinas;

- reconhecimento do despreparo das associações para lidar com o novo ambiente desregulamentado (já que até então as questões técnicas eram consideradas mais relevantes que as econômicas);

- falta de participação dos associados;

- a forma de remuneração do setor anteriormente existente distanciou o fornecedor das questões dos mercado, o qual tem dificuldade em analisar os problemas decorrentes da super oferta, restringindo a aceitação do modelo;

- os pequenos, que individualmente não representam parcela significativa da cana das usinas, enfrentam condições piores de negociação que os poucos grandes;

- A diferença de peso entre as duas classes é desfavorável para o fornecedor;

- a pulverização dos fornecedores (que são muito numerosos e pequenos) dificulta uma união para melhor negociação com as usinas.

\footnotetext{
${ }^{99}$ É interessante notar que mesmo em Sertãozinho, que é a maior associação de fornecedores do mundo, tendo moído na safra de 1998/99 aproximadamente 17 milhões de toneladas de cana, onde os fornecedores participam com 35 a $40 \%$ das canas da região, também foram levantados diversos problemas neste primeiro ano de uso do CONSECANA
} 
As opiniões dos entrevistados ligados ao setor industrial em relação ao CONSECANA também não foram unânimes. Dos entrevistados deste grupo 15 se posicionaram a respeito do CONSECANA, sendo que todos concordam que ele deve ser usado. A maioria considera o modelo justo, porém divergem quanto à necessidade da regulamentação governamental.

$\mathrm{O}$ argumento daqueles que pensam que o modelo pode funcionar totalmente sem regulamentação do governo (64\%), através da autogestão, é que uma vez estabelecidos os contratos, a Câmara Arbitral é apta para resolver eventuais conflitos, já que é considerada a última instância pela Lei do Juízo Arbitral (Lei № 9.307, de setembro de 1996). Segundo o artigo $31^{\circ}$ da referida lei, a sentença arbitral produz, entre as partes e seus sucessores, os mesmos efeitos da sentença proferida pelos órgãos do poder judiciário, e sendo condenatória, constitui título executivo.

Além disso, as pendências seriam resolvidas num prazo bastante menor que a justiça comum, não acarretando em perdas para nenhuma das partes, já que conforme a referida lei, a sentença arbitral será proferida no prazo estipulado pelas partes, quando não houver sido estipulado o prazo, ele será de seis meses (artigo $23^{\circ}$ ).

Estes entrevistados argumentaram que a cadeia sucroalcooleira estava desbalanceada há alguns anos, já que a matéria-prima (responsável em média por 60\% do custo de produção) era paga a preços tabelados pelo governo e os produtos finais já começavam a ser vendidos em ambiente de livre mercado (no caso do açúcar desde o início dos anos 90), ou já começavam a sofrer deságio devido a super oferta existente nos últimos anos.

Alguns inclusive afirmaram que vem ocorrendo uma transferência significativa de renda do setor industrial para o agrícola, e que a viabilidade da cadeia como um todo depende desta nova forma de remuneração da cana-de-açúcar.

Neste grupo há consenso também de que o modelo é técnica e economicamente bom, porém foi implantado num momento de super oferta dos produtos finais, na qual os preços achatados destes produtos inevitavelmente foram repassados para o produtor, 0 que acabou dificultando sua aceitação. 
Além deste fato, fatores externos ao modelo, como os diversos adiamentos da liberação dos preços, foram citados como prejudiciais à sua aceitação e ao relacionamento entre as partes.

Desta forma, crêem que o CONSECANA pode ser capaz de administrar os conflitos de interesses entre fornecedores e produtores, que o governo nada teria para agregar de valor ao modelo, e que as discussões relevantes para se superar as dificuldades iniciais deveriam ser sobre os parâmetros do modelo (por exemplo a eficiência industrial da unidade, qual seu mix de produção, como captar os preços) e não sobre sua utilização.

Estes entrevistados ressaltaram a importância das associações dos fornecedores, em esclarecer seus associados sobre a necessidade de contratos, como forma de se garantirem. Destacaram também que certas questões, tais como: considerações sobre eficiência dos canaviais, escala mínima de produção, distância das unidades industriais, passam a ser extremamente relevantes, pois muitos canaviais que eram viáveis com preços tabelados deixarão de ser num ambiente de livre mercado.

Ainda dentro da categoria dos industriais que se manifestaram sobre o CONSECANA existe uma parte $(34 \%)$ que acredita que o modelo só funcionará com a regulamentação do governo. Primeiramente por acharem que a solução negociada que ocorreu em São Paulo não vai necessariamente acontecer em outros estados, e que o governo deveria homologar o uso do CONSECANA para todo o Brasil (adequando os parâmetros técnicos do modelo para as diferentes regiões), estipulando punições no caso do não cumprimento por qualquer uma das partes.

Salientam que as dificuldades encontradas por alguns no uso do CONSECANA na safra $98 / 99$ podem ser muito maiores na ausência de um contrato formal entre as partes, já que a legislação anteriormente utilizada é de difícil aplicação nos dias atuais.

Ou seja, embora possam surgir conflitos entre as partes que estejam adotando o CONSECANA, o problema consiste em se executar os instrumentos previstos nos contratos, que é uma situação melhor do que não se ter um contrato para executar. Consideram que sem um mínimo de regulamentação, que imponha a utilização de 
contratação entre as partes, o excedente de produção pode significar que a cana sem moer será a do fornecedor.

Também foi ressaltado que o modelo tem a capacidade de distribuir a renda gerada pela atividade entre os agentes, preservando o fornecedor, que pode ser elemento importante dada uma retomada do setor, porque as usinas estão descapitalizadas e não terão, se necessário condições de assumir a parte agrícola.

Desta forma, consideram que as especificidades técnicas da cana requerem uma negociação via contratos, e que é necessário um mínimo de regulamentação estatal de forma a garantir que o pagamento de cana através de fórmula paramétrica seja usado por todos os produtores, em todos os estados brasileiros.

Conforme Silva $(1999)^{100}$, outros países já adotam a remuneração da cana-deaçúcar em função do preço do açúcar, através de fórmulas paramétricas, dentre eles Colômbia, México, Venezuela, Bolívia, Costa Rica, Austrália, África do Sul, Tailândia e Argentina. Porém, não existe um padrão no que se refere à participação do governo nas negociações entre fornecedores e industriais: enquanto na Argentina, na África do Sul, na Bolívia e na Colômbia, as negociações são bipartites, no México e na Austrália há interferência do governo.

Da parte do governo, embora se reconheça a existência de problemas neste elo da cadeia produtiva (fornecimento de cana para as indústrias), dadas as inúmeras reivindicações feitas pelos agentes, ainda não existe clareza sobre a necessidade ou não de se fazer uma regulamentação, nem qual a melhor forma de fazê-la.

Há dois anos atrás, o governo considerou que a fórmula paramétrica desenvolvida pelos produtores e industriais de São Paulo seria um modelo interessante, e que os contratos particulares seriam uma boa forma de resolver eventuais conflitos entre as partes, não sendo necessária a interferência estatal.

Porém, com o mercado super ofertado como ocorreu nas safras 1998/99 e 1999/00, e não existindo mais a obrigatoriedade das usinas receberem as cotas de cana

${ }^{100}$ SILVA, G.M.A. Consultor da Câmara Técnica do CIMA, Comunicação pessoal, 1999. 
dos fornecedores, estão surgindo dificuldades e muitos pedidos têm chegado ao governo no sentido de se regulamentar esta relação.

Desta forma, a opinião governamental é que num mercado equilibrado o modelo funcionaria bem ${ }^{101}$, sem necessidade de sua interferência, mas que dadas as diferenças regionais e a crise de super oferta existentes, a necessidade da regulamentação está sendo reavaliada.

Do que foi relatado nas entrevistas, conclui-se que embora se reconheça que exista uma nova geração de fornecedores e de industriais, com técnicas de gerenciamento modernas e preocupados com questões de eficiência e relações de parceria, sabe-se que historicamente as relações entre as duas partes sempre foram conflituosas, e que a maioria, longe de se comportar como parceiros, procurando relacionamentos estáveis, visa resultados imediatos, existindo atitudes oportunistas, que tendem a se complicar em ambiente de livre mercado.

Portanto, as especificidades da cana e do processo produtivo, que causam uma dependência bilateral entre os agentes, a falta da existência de compromissos confiáveis entre eles, o novo ambiente institucional desregulamentado e a inadequação da legislação existente requerem que esta transação seja regida por contratos ${ }^{102}$.

Embora se reconheça que a lentidão do sistema legal brasileiro em muito dificulta a utilização da justiça no caso de um litígio entre as categorias, devido às especificidades temporais envolvidas, a existência de um contrato ao menos possibilita que os agentes tentem fazer valer o acordado. Por sua vez, espera-se que os agentes que

\footnotetext{
${ }^{101}$ Se a produção é compatível com a demanda, o fornecedor passa ser necessário para que se atinjam os níveis requeridos de produção, e emerge uma parceria entre as partes de modo que o fornecimento esteja assegurado.

${ }_{102}$ Deve ficar claro que não implica necessariamente em se adotar o CONSECANA, mas qualquer forma de contrato estabelecido entre as partes e conveniente para ambas.
} 
adotarem o CONSECANA obtenham soluções para seus litígios de forma mais rápida (através da utilização da Lei do Juízo Arbitral.)

\subsubsection{A diferença competitiva entre fornecedores de cana e industriais}

Em relação à diferença citada entre o número de fornecedores e indústrias, e à diferença de "peso" entre as duas categorias, que pode caracterizar a existência de uma falha de mercado, é interessante analisar alguns dados da safra 1998/99, dos principais estados produtores, apresentados pela Organização dos Plantadores de Cana do Estado de São Paulo (ORPLANA).

Tabela 9. Número de fornecedores e participação na cana entregue safra 98/99.

\begin{tabular}{lrrrrr}
\hline \multirow{2}{*}{ Estado } & \multicolumn{5}{c}{ Cana Entregue (toneladas) } \\
\cline { 3 - 6 } & $N^{2}$ & Produtores & \% Produtores em & Própria & \multicolumn{1}{c}{ Total do } \\
& produtores & & relação ao total & Indústria & \multicolumn{1}{c}{ Estado } \\
\hline São Paulo & 11.570 & 51.595 .640 & 25,86 & 147.925 .613 & 199.521 .253 \\
Pernambuco & 8.390 & 6.536 .000 & 36,67 & 11.289 .699 & 17.825 .699 \\
Alagoas & 5.202 & 5.853 .467 & 23,48 & 19.073 .078 & 24.926 .545 \\
Minas Gerais & 497 & 3.652 .724 & 24,24 & 11.415 .130 & 15.067 .854 \\
Rio de Janeiro & 11.003 & 2.826 .989 & 55,84 & 2.235 .270 & 5.062 .259 \\
Paraíba & 980 & 1.415 .064 & 30,46 & 3.230 .307 & 4.645 .371 \\
Paraná & 145 & 1.353 .000 & 7,28 & 17.242 .000 & 18.595 .000 \\
Espírito Santo & 356 & 630.989 & 77,10 & 187.430 & 818.419 \\
R. G. do Norte & 238 & 361.597 & 15,08 & 2.035 .652 & 2.397 .249 \\
Sergipe & 40 & 316.778 & 44,98 & 387.454 & 704.232 \\
Mato Grosso & 6 & 120.159 & 8,82 & 1.241 .657 & 1.361 .816 \\
Amazonas & 120 & 86.123 & 79,34 & 22.420 & 108.543 \\
Bahia & 144 & 71.000 & 3,97 & 1.717 .000 & 1.788 .000 \\
Pará & 103 & 17.645 & 20,49 & 68.478 & 86.123 \\
\hline Total & 38.815 & 77.539 .559 & 27,25 & 207.011 .062 & 284.550 .621 \\
\hline Fonte: elaborado & & & & & \\
\hline
\end{tabular}

Fonte: elaborado a partir de dados da ORPLANA. 
Conforme a tabela 9, observa-se que os produtores de cana independentes, participaram, em média, com $27 \%$ da produção de cana total entregue no Brasil na safra 1998/99, que foi ao redor de 285 milhões de toneladas. No principal estado produtor de cana-de-açúcar (São Paulo, que corresponde a 70\% da cana entregue), os 11.570 fornecedores participaram apenas com $26 \%$ de toda a matéria-prima da referida safra .

Em relação ao tamanho individual dos fornecedores de cana, no Estado de São Paulo, é interessante analisar a sua distribuição por estratos de produção, conforme a tabela 10.

Tabela 10. Distribuição dos produtores de cana por estratos - safra 1998/99 Estado de São Paulo.

\begin{tabular}{ccccc}
\hline Estrato de produção & \multicolumn{2}{c}{ Produtores } & \multicolumn{2}{c}{ Produção } \\
& Número & $\%$ do Total & Toneladas & $\%$ do Total \\
$<200 \mathrm{t}$ & 1.116 & 9,6 & 128.697 & 0,2 \\
$201-800 \mathrm{t}$ & 3.023 & 26,1 & 1.422 .540 & 2,8 \\
$801-4.000 \mathrm{t}$ & 4.836 & 41,8 & 9.235 .755 & 17,9 \\
$4.000-10.000 \mathrm{t}$ & 1.514 & 13,1 & 9.333 .874 & 18,1 \\
$>10.000 \mathrm{t}$ & 1.081 & 9,3 & 31.474 .538 & 61,0 \\
Total & 11.570 & 100 & 51.595 .404 & 100,0 \\
\hline
\end{tabular}

Fonte: elaborado a partir de dados da ORPLANA.

Nota-se pelos dados da tabela 10 que, no Estado de São Paulo, aproximadamente $77,5 \%$ dos fornecedores de cana são pequenos, com produção de até 4.000 toneladas por ano, sendo responsáveis por aproximadamente $21 \%$ da cana entregue. Os produtores médios (com produção entre $4.000 \mathrm{t}$ e $10.000 \mathrm{t}$ de cana) representam $13,1 \%$ do total e participam com $18 \%$ da cana entregue. Os restantes $61 \%$ da produção foram realizados por $9 \%$ dos produtores, que entregaram mais de 10.000 toneladas de cana. 
A área média de produção de cana neste Estado é de 52 ha. Na Associação de Sertãọzinho, que é a maior associada da ORPLANA em termos de produção (18 milhões de toneladas, que corresponderam a $35 \%$ do total entregue pelas afiliadas na safra 98/99), a área média de produção de cana é de 87ha; na Associação de Piracicaba, que é a segunda maior (8,5 milhões de toneladas, $17 \%$ do total) este valor é de 28 ha $^{103}$.

Por sua vez, em todo o Brasil existem 324 unidades industriais, das quais 133 em São Paulo, ou seja, o número de fornecedores é muito maior que o de industrias, e sua participação relativa em relação a cana entregue é bem menor a das usinas.

À luz da teoria, a possibilidade de ocorrência de falhas de mercado e a consequiente necessidade de ação estatal merecem ser avaliadas. Algumas características das estruturas dos mercados relevantes ${ }^{104}$ de cana-de-açúcar (que são bastante distintos entre as regiões, mesmo dentro do Estado de São Paulo), são indicativas de falhas de mercado e determinantes para que a ação do Estado se faça presente.

Partindo-se do princípio de que a cana é um produto homogêneo, em regiões onde existam muito fornecedores pequenos e somente uma usina (ou poucas), ou seja, onde exista um monopsônio (ou oligopsônio), o único comprador pode exercer seu poder de monopsônio, pagando pela cana preços menores que os praticados em um mercado onde existe concorrência, já que o fornecedor não teria outra opção para vender seu produto.

Este pode ser o caso, por exemplo, de algumas regiões do Norte/Nordeste (Piauí, Maranhão), ou mesmo em regiões do Centro/Sul que passam por processos de fusões de usinas, restringindo as possibilidades para o fornecedor vender sua cana (Piracicaba, Barra Bonita, Jaú).

\footnotetext{
${ }^{103}$ Conforme o site da UDOP: http://www.udop.com.br.

${ }^{104}$ É de grande importância a definição correta de qual é o mercado de atuação da firma, ou qual é o mercado para o qual estão se calculando os índices de concentração, que são usados para se definir a estrutura do mercado e o poder de mercado existente. Se a definição do mercado é muito ampla, de tal forma que as firmas não estão realmente competindo entre si. as medidas de concentração serão menores do que as reais; por outro lado, se o mercado é definido "estreito" demais, as medidas de concentração serão mais altas do que deveriam, indicando um poder de mercado que realmente não existe.
} 
No outro extremo, supondo-se que existam diversas usinas competindo pela cana de um (ou poucos) fornecedores grandes em relação ao mercado (monopólio ou oligopólio). Neste caso, os fornecedores poderiam cobrar pela cana preços maiores que os de um mercado competitivo, já que as diversas usinas estariam "brigando" por ela.

Esta situação ocorria, por exemplo, anteriormente nas regiões de Ribeirão Preto e Sertãozinho, onde o ágio pago pela matéria prima e o valor dos arrendamentos sempre foi maior que o das outras regiões canavieiras.

Entre os dois casos extremos, existe uma infinidade de situações intermediárias a serem analisadas, mas a ação estatal pode ser necessária de forma a impedir que os comportamentos dos agentes, decorrentes de estruturas de mercado concentradas, se afastem do ideal competitivo, implicando em perdas de bem estar da sociedade como um todo. Porém, a ação do Estado nestes casos não é a de fixar preços para o produto, nem a de regulamentar a relação.

Conforme Farina et al. (1997), quando o exercício de poder de monopólio decorre de estruturas de mercado oligopólicas, a ação do Estado deve ser no sentido de controle do abuso do poder econômico, através da utilização de uma política antitruste. Neste caso, cabe ao Estado aplicar a legislação antitruste existente.

Portanto, se houver indícios de abuso de poder econômico, primeiramente é feita uma análise da questão pela Secretaria de Desenvolvimento Econômico (SDE), ligada ao Ministério da Justiça, e pela Secretaria de Acompanhamento Econômico (SEAE), vinculada ao Ministério da Fazenda, que instruem o processo, o qual é posteriormente julgado pelo Conselho Administrativo de Defesa Econômica (CADE) ${ }^{105}$.

\footnotetext{
105 A tramitação dos processos segue o seguinte fluxo: a SDE instaura o processo, enviando cópias das informações para a SEAE e para o CADE. Após receber a documentação a SEAE tem determinado prazo para preparar um parecer sobre $O$ caso, sendo considerados na análise aspectos econômicos, tais como estrutura de mercado, grau de concentração, etc. O parecer da SEAE é enviado à SDE que também tem um prazo determinado para deliberar sobre o caso, sendo que então são considerados os aspectos jurídicos relevantes. O parecer da SDE é publicado no "Diário oficial da União" e encaminhado ao CADE. No CADE é sorteado um relator para julgar o caso, que tem um prazo determinado para dar a decisão. O relator do CADE considera os pareceres da SEAE e da SDE, mas tem liberdade para chegar a conclusão independente.
} 
Portanto, ao CADE compete julgar o processo por abuso do poder econômico instaurado, além dos atos para prevenção, correção e impedimento de práticas atentórias à ordem econômica. Desta forma, constatado o abuso do poder econômico, a ação estatal seria baseada na legislação antitruste existente (Lei № 8.884 ), através do CADE.

Porém, verificada a falha de mercado decorrente da estrutura de mercado concentrada e a incapacidade do mercado em alocar os recursos eficientemente, requerendo uma ação por parte do Estado, não devem ser esquecidas, conforme visto anteriormente, as falhas de governo, que muitas vezes impedem que a ação estatal consiga atingir os objetivos pretendidos.

Além disso, a especificidade temporal da cana é um fator que dificulta a utilização da justiça, mesmo considerando os prazos menores que os processos instaurados no CADE costumam ser julgados.

Uma outra forma para resolver os eventuais conflitos entre fornecedores e indústria poderia ser através de câmaras setoriais, formada pelos segmentos envolvidos e pelos respectivos governos estaduais, nas quais, dentre outras coisas, poderiam ser discutidas e negociadas as questões conflitantes, cabendo aos governos o papel de coordenador e mediador dos conflitos.

Conforme Farina et al. (1997), as câmaras setoriais, com a participação de toda a cadeia produtiva e do Estado, podem funcionar como fóruns para se identificar as áreas de cooperação entre os segmentos e ajudar na solução dos conflitos distributivos existentes.

Segundo a autora, embora existam situações em que os benefícios de uma ação coordenada e cooperativa ao longo da cadeia sejam evidentes, a distribuição dos benefícios pode gerar motivo para a barganha e inviabilizar a realização dos mesmos. No Estado de São Paulo, a Câmara Paulista do Setor Sucroalcooleiro, criada em dezembro de 1995, poderia ser um fórum de discussões sobre estas questões, cabendo ao governo, conforme salientado, o papel de mediador dos conflitos, considerando a cadeia como um todo. 
É interessante notar que, no Estado de São Paulo, o "Pacto pelo Emprego no Agronegócio Açucareiro" (que teve origem a partir das discussões da Câmara Paulista do Setor Sucroalcooleiro), prevê a utilização do CONSECANA, sendo portanto mais um fórun no qual as partes podem tentar encontrar soluçôes para os problemas, e que neste caso tem a participação e coordenação dos Governos Federal e Estadual.

Embora o CONSECANA seja um novo modelo de auto-gestão privada para administrar a comercialização da cana e os eventuais conflitos entre as categorias, deve ser lembrado que ele somente se aplica aos participantes que adotarem a nova fórmula de remuneração da cana-de-açúcar estipulada nestes contratos.

A participação do governo como mediador dos conflitos parece ter o aval das associações dos fornecedores de cana-de-açúcar. Em janeiro de 1999 as principais lideranças canavieiras realizaram uma Mesa Redonda, na cidade de Piracicaba, e redigiram a "Carta de Piracicaba"106, que foi levada ao conhecimento do Governo Federal e do público em geral. Uma das reivindicações feitas na referida Carta foi a definição de um organismo público federal para mediar o relacionamento dos produtores de cana-de-açúcar e a indústria.

Em relação a diferença de poder entre as duas categorias, que pode influir nas negociações, deve ser lembrado que o poder de barganha depende da paridade entre elas, ou seja, é importante que os fornecedores se organizem de forma que a negociação se faça de forma mais eqüitativa, melhorando as condições para os mesmos.

Conforme Neves et al. (1999), diversos arranjos institucionais podem ser utilizados para contrabalançar o maior poder de mercado dos processadores e distribuidores nos sistemas agroindustriais, dentre eles as cooperativas, as associações setoriais, os marketing orders, e os sinais de qualidade. Segundo os autores, os produtores organizados em cooperativas têm maior poder de negociação sobre os preços e termos contratuais, contrabalançando o poder de mercado das empresas à jusante montante do sistema agroindustrial.

\footnotetext{
${ }^{106}$ Conforme Informativo Orplana, Ano VI, nº 1, janeiro de 1999, p.1.
} 
Neste sentido, as associações de fornecedores também têm um importante papel a desempenhar. Além disso, é primordial que as mesmas se adeqüem ao novo ambiente institucional, se capacitando e suprindo seus associados com informações de mercado, tendências de preços e decisões de produção, de forma a reduzir as assimetrias de informação existentes.

Em relação ao papel do Estado neste elo da cadeia, provavelmente será bastante diferente do previamente exercido ${ }^{107}$, mesmo porque o novo ambiente institucional, amparado na Constituição Federal de 1988, em muito dificultaria uma ação do Estado nos moldes anteriores.

Espera-se que ele aja como coordenador das atividades da cadeia sucroalcooleira e atue como mediador dos conflitos entre fornecedores e industriais, considerando as questões de emprego e renda e as especificidades dos ativos envolvidos, que dificultam a utilização da justiça comum.

Além disso, outro papel importante a ser desempenhado pelo governo é a de corrigir ou evitar as falhas de mercado, que neste caso seria impedir que a existência de mercados monopólicos ou monopsônicos leve ao exercício do poder de mercado, e se isto for verificado, agir de forma a coibir este tipo de conduta através da legislação existentes e dos seus órgãos competentes (CADE).

\subsubsection{O mercado de açúcar}

A análise das características da produção e comercialização de açúcar objetiva a identificação de falhas de mercado que possam necessitar algum tipo de ação do Estado, bem como as formas mais eficientes de comercializar o produto.

Dos 14 representantes dos industriais que se posicionaram a respeito, aproximadamente $86 \%$ consideram que a produção e comercialização do açúcar deve ser feita em ambiente de livre mercado. Diversas razões foram citadas para justificar que a presença do Estado não se faz necessária neste elo da cadeia produtiva, dentre elas:

\footnotetext{
107 Quando estabelecia preços para os produtos e insumos das cadeias agroindustriais, e cotas de fornecimento para às unidades industriais e fornecedores de cana-de-açúcar.
} 
- é um produto secular, uma commodity produzida no mundo todo (por países ricos e pobres, de climas temperado e tropical, e pode ser extraído tanto da beterraba como da cana-de-açúcar);

- no caso de falta do produto, existem países de onde importá-lo;

- existem muitos produtores do produto no Brasil (em torno de 300 usinas) e milhares de compradores, tanto no mercado doméstico (supermercados, indústrias de alimentos, de bebidas, etc.) como externo (açúcar demerara, VHP, acabado branco);

- os mecanismos de comercialização atualmente existentes (dentre eles as bolsas de mercadorias) permitem que sua comercialização seja feita sem ambiente de livre mercado.

Desta parcela dos industriais alguns ressaltaram que certas questões que até pouco tempo atrás não eram familiares ao setor, tais como: relacionamento com cliente; qualidade do produto que atenda os desejos do consumidor; contratos e fidelidade de entrega; modelos de logística; marcas de distribuição; etc. devem passar a fazer parte do dia a dia dos produtores.

Nota-se inclusive estratégias de alguns no sentido de diferenciação de produtos (seja pela qualidade, marca, embalagem, etc.), procurando alternativas para o mercado de commodities, e atendimento de nichos de mercado. ${ }^{108}$

Os industriais citaram também a necessidade de um fórum de discussão dentro do próprio setor para o planejamento da oferta do produto, já que existe um limite para o consumo mundial, e que se a produção e as exportações forem excessivas, os reflexos

\footnotetext{
108 Dentre vários exemplos, estão o açúcar orgânico (que é produzido sem agrotóxicos, com bastante aceitação na Europa) da usina São Francisco, de Sertãozinho, que desde 1997 é vendido na Europa e foi lançado no mercado interno em abril de 1999; o lançamento de um açúcar orgânico com o selo Greenpeace, feito pela Univalem S.A. Açúcar e Álcool; a Cia União, que pretende lançar um açúcar em cubos, para usar o peso de sua marca em produtos de maior valor agregado; a usina Nova América, que lançou o açúcar refinado Dolce em vários tamanhos de embalagens; a Cargill e a Açúcar Guarani, que desenvolveram uma mistura de açúcar e estão conseguindo exportar para o Canadá, Japão e Oriente Médio; a usina Albertina, que lançou o Sucareto em embalagens descartáveis de 250gramas; e a usina da Barra, que está desenvolvendo um novo tipo de açúcar (Lowsugar).
} 
nos preços são imediatos, principalmente quando se considera que hoje o Brasil participa com praticamente $20 \%$ do total mundial exportado.

Outro fator levantado é que a oferta do açúcar depende dos preços do produto alternativo (o álcool combustível), e que o equilíbrio do mercado do álcool é fundamental para que os preços do açúcar fiquem em patamares aceitáveis. Embora exista uma migração para um ou outro produto conforme seus preços relativos, há um certo limite para esta flexibilidade produtiva (ou seja, não é possível que toda cana plantada para álcool se transforme em açúcar), já que são necessários investimentos no setor produtivo para que isto aconteça.

Porém, o controle da oferta do açúcar seria feito, conforme os entrevistados, a partir de um acordo setorial, através de uma auto-gestão, sem interferência do governo, ou seja, dificuldades conjunturais nos preços não indicam que o governo deva regulamentar este mercado.

É evidente que mecanismos de auto-regulação dependem de uma evolução associativa muito grande do setor, já que as ações conjuntas em torno de um objetivo comum não é característica da sua história.

Os $14 \%$ que consideram que o Estado deva intervir salientam que esta forte dependência entre os dois produtos requer um planejamento estatal, sendo inclusive citado que o governo deveria ordenar os volumes de açúcar exportáveis (os que excedessem o consumo doméstico) por unidade produtiva.

Uma opinião unânime entre os 14 entrevistados em relação ao papel do Estado neste elo da cadeia produtiva, é que é de fundamental importância a adoção de uma política mais agressiva no mercado internacional, de modo a derrubar as barreiras existentes e abrir mercado para os produtos nos quais o Brasil apresenta vantagens competitivas, como o açúcar.

Tanto os Estados Unidos como a União Européia adotam políticas que restringem as exportações do açúcar brasileiro. É interessante notar que o açúcar é um dos poucos produtos que resistiram à tendência liberalizante da política adotada para os grãos nos Estados Unidos. 
A política americana consiste em limitar as quantidades de açúcar importado, sustentando os preços internos em níveis bastante elevados para assegurar a produção interna. Para suprir a demanda doméstica, os volumes importados são distribuídos através de cotas preferenciais para países exportadores selecionados.

Acima destas quotas, existe a incidência de uma tarifa que tornam as importações proibitivas. A cota brasileira para o mercado preferencial norte-americano é preenchida com açúcar da região Nordeste. Alguns países que possuem cotas para o mercado preferencial norte-americano, e que não conseguem preenchê-las com sua produção, chegam a importar açúcar para reexportá-lo para este mercado, no qual se praticam preços mais elevados que o mercado internacional.

Por sua vez, a União Européia possui um complexo sistema de cotas (A, B, e C), sendo fixado um preço diferente para cada uma, o que implica em lucratividades distintas. Os excedentes (aproximadamente 50\% do consumo) são exportados a preços inferiores aos praticados no mercado interno (para torná-los competitivos internacionalmente), através de elevados subsídios.

Em ambos os casos as políticas adotadas são suportadas pelos consumidores dos produtos. Embora estas políticas tendam a ser pressionadas por grupos de consumidores, de contribuintes, por pesquisadores e mesmos por alas do governo, podendo ocorrer uma mudança, esta, se ocorrer, não será repentina, principalmente quando se consideram os interesses e o forte lobby feito pelos produtores destes países.

Desta forma, é necessária uma política agressiva do Brasil para que sejam eliminadas as exportações subsidiadas, os sistemas de cotas preferenciais e de tarifas, para que o país possa conquistar estes mercados, através da competitividade de sua agroindústria canavieira.

Esta é também a opinião da representante do governo entrevistada, que salientou que as negociações internacionais são feitas entre governos, cabendo portanto ao Estado, e que a posição da diplomacia brasileira é contrária aos mercados preferenciais (no caso referindo-se ao Mercado Preferencial americano). 
Em relação às formas mais eficientes de se transacionar o produto, não foram identificadas especificidades importantes que justificassem a adoção de formas hierárquicas. Desta forma, espera-se que a utilização do mercado seja a mais eficiente.

\subsubsection{O mercado de álcool combustível}

Ao se analisar o mercado de álcool combustível (anidro e hidratado), procurouse, da mesma forma que feito para os da cana-de-açúcar e do açúcar, identificar suas características para avaliar a necessidade de intervenção estatal neste elo da cadeia produtiva.

Os grupos dos industriais, dos parlamentares e do governo foram os que se posicionaram sobre este mercado, levantando algumas questões indicativas da necessidade da presença do Estado, dentre elas: o álcool não compete com a gasolina em ambiente de livre mercado; as externalidades existentes no uso e produção deste combustível; a diferença competitiva entre as distribuidoras e os produtores de álcool; e os problemas de adulteração e sonegação do mercado de combustíveis, as quais são analisadas a seguir.

\subsubsection{A falta de competitividade do álcool hidratado em relação a gasolina}

A primeira questão levantada pelos entrevistados destes grupos em relação ao álcool combustível é que, a preços de mercado, sem se considerar os custos ambientais embutidos na utilização dos combustíveis fósseis, ele não compete com a gasolina porque seus custos de produção são maiores, ou seja, os preços que viabilizam a atividade são mais altos que os dos derivados de petróleo, dificultando sua aceitação em ambiente de livre mercado.

Conforme Ribeiro (1997), embora os custos de produção do álcool venham decrescendo desde 1976 a uma taxa cumulativa de $3 \%$ ao ano devido a ganhos de eficiência e produtividade na agroindústria açucareira (passaram de US\$75 dólares por barril para US\$45 dólares por barril entre 1976 e 1993), e exista um potencial de redução 
de cerca de $22 \%$ com a tecnologia já disponível, eles ainda são mais altos que os custos de produção da gasolina.

Além disso, segundo a autora, para se comparar o custo do álcool com o da gasolina deve ser considerado que o consumo do álcool hidratado é maior devido à sua potência energética ser $20 \%$ menor do que a da gasolina nos motores de ciclo Otto. Por sua vez, o álcool anidro e a gasolina são equivalentes em poder energético.

O custo da gasolina, segundo Ribeiro (1997), é obtido a partir do custo de petróleo considerando-se os custos de refino $(9 \%$ do custo de petróleo mais uma parcela fixa de US $\$ 2,5$ dólares por barril) e o custo de transporte (US $\$ 2,5$ dólares por barril), resultando na seguinte equação:

\section{Custo gasolina $=1,09$ Preço barril petróleo $+U S \$ 5 /$ barril}

Desta forma, embora exista uma tendência declinante nos custos de produção do álcool combustivel, e se trabalhe com uma projeção, para o final da década, de um custo médio de produção de US\$35 dólares o barril (Ribeiro, 1997), atualmente seus custos de produção são maiores que o da gasolina e sua competitividade com este produto não é assegurada, principalmente quando se considera a flexibilização do monopólio da Petrobrás e a liberação dos preços dos combustíveis nas refinarias em agosto de 2.000 .

Além do custo mais alto de produção, conforme Serodio et al. (1998), outra desvantagem competitiva do álcool combustível é a sazonalidade de sua produção (que obedece ao calendário agrícola da cana-de-açúcar), implicando em elevados custos de estocagem para garantir seu abastecimento ao longo do ano.

Dos 18 industriais ouvidos, aproximadamente $83 \%$ consideram que o governo não pode se afastar sem resolver o problema da definição do preço de paridade na bomba entre os dois combustíveis.

Conforme visto anteriormente, a determinação de preços relativos dos combustíveis liquidos feita até hoje pelo governo segue um modelo de sustentação econômica indireta ao álcool, feito através da Parcela de Preços Específica (conta 
administrada pela Agência Nacional do Petróleo), que lhe permite competir com a gasolina.

Os recursos para o apoio ao álcool (e para outros programas do governo) vêm de um sobre-preço cobrado dos combustíveis derivados de petróleo, que se extinguirá em agosto de 2000, conforme determinação da Lei № $9.478 / 97$, que dispõe sobre a política energética nacional e que objetiva implantar o regime de livre mercado para os combustíveis derivados de petróleo.

Nesta data, com a flexibilização do monopólio da Petrobrás, encerra-se também a conta Parcela de Preços Específica (PPE) e o mecanismo de sustentação do álcool combustível, já que em ambiente de livre mercado as novas refinarias não aceitarão um sobre-preço ao seu produto para suportar o concorrente.

Existe um consenso entre os entrevistados de que para ser atrativo para o consumidor, o álcool hidratado deve custar, na bomba, no máximo $75 \%$ do preço da gasolina. ${ }^{109}$ Com o mercado dos combustíveis liberados a partir de agosto de 2000 , conforme os preços que vigorarem para a gasolina, e mantendo esta relação entre os preços finais, não é assegurado que o preço resultante para o álcool hidratado seja suficiente para cobrir os custos de produção deste produto.

Portanto, se a política energética do governo contemplar o uso do combustível renovável, as forças de mercado podem ser insuficientes para que se atinja este objetivo, tornando necessário um mecanismo tributário que torne seu consumo atraente para os consumidores.

A opinião unânime destes entrevistados é que a solução para a falta de competitividade do álcool combustível é a criação de um Imposto Seletivo sobre os combustíveis, que incidiria com diferentes percentuais sobre os diversos combustíveis, de forma a permitir a convivência entre a gasolina e o álcool.

Os combustíveis fósseis, mais poluentes, teriam uma taxação maior que o combustível de biomassa, resultando num preço final maior dos derivados do petróleo,

\footnotetext{
${ }^{109}$ Embora o motor a álcool seja mais potente que o da gasolina (para compensar o menor poder calorífico do combustível vegetal ele é comprimido com mais intensidade na câmara de combustão, aumentando a potência do motor) seu consumo é maior, justificando um preço na bomba menor para atrair o consumidor.
} 
permitindo a convivencia entre álcool hidratado e gasolina em ambiente de livre mercado.

A diferença de preços estabelecida pelo Imposto Seletivo seria um instrumento de intervenção de forma a atender as diretrizes do governo relativas ao Planejamento Energético, Econômico, Agrícola e Ambiental.

Portanto, os preços dos combustíveis fósseis (gasolina, diesel, nafta, óleo combustível e GLP) seriam formados pelo preço de fronteira do petróleo, de forma a remunerar as refinarias, acrescido das alíquotas de imposto diferenciadas. E o imposto incidente sobre o álcool combustível (anidro e hidratado) seria menor, como forma de incentivar seu uso e atingir os objetivos citados, dadas as externalidades positivas existentes neste produto.

Os entrevistados consideram o Imposto Seletivo uma tributação moderna, eficaz e transparente, e ressaltaram que não seria a criação de mais um imposto, e sim a substituição da carga tributária atualmente existente (PIS, COFNS, ICMS e PPE). Outros países já adotam o imposto sobre combustíveis com aliquotas diferenciadas, como os Estados Unidos e a Inglaterra. ${ }^{110}$

Porém, para o Imposto Seletivo ser aprovado, é necessária uma emenda Constitucional, porque hoje a Constituição brasileira não permite que os derivados de petróleo sejam tributados pelo Governo Federal, sendo possível somente a tributação estadual, o que requer uma negociação bastante efetiva no Congresso Nacional.

110 Conforme a Associação Brasileira da Indústria do Álcool (1997), nos Estados Unidos existem três tipos de taxação sobre os combustíveis: (a) taxa federal (excise tax) de US\$18,4 cents de dólar por galão; (b) taxa estadual, que varia de US\$90 cents de dólar a US\$31/32 cents de dólar por galão; (c) alguns tributos municipais. Contudo, a partir de 1990, com a promulgação do Clean Air Act, foram dados incentivos ao uso do etanol, como forma de melhorar o desempenho e prevenir a poluição ambiental: se a gasolina for misturada com $10 \%$ de etanol, o imposto federal de reduz de US\$18,4 cents de dólar por galão para US $\$ 13$ cents de dólar por galão, e os misturadores ficam isentos do recolhimento de US\$54 cents de dólar por galão. Além disso, em alguns estados americanos produtores de milho são concedidos incentivos adicionais ao uso do etanol, no valor médio de US $\$ 4,5$ cents de dólar por galão.

$\mathrm{Na}$ Inglaterra, embora o governo não interfira diretamente no mercado através de fixação de preços ou subsídios, ele se utiliza da estrutura tributária diferenciada para dar direcionamento ao mercado de combustiveis: existe redução da carga físcal sobre a gasolina sem chumbo, gás natural combustível e sobre os combustíveis utilizados nos transportes públicos. Por outro lado, a taxação para a gasolina com chumbo sofre uma taxação maior. 
E interessante notar que outros agentes da cadeia, como o Sindicom, também aprovam o Imposto Seletivo como forma de reduzir a sonegação fiscal, já que a forma de sua aplicação dificulta a sonegação e facilita a fiscalização.

Desta parcela de $83 \%$ do grupo de industriais que se posicionou a respeito da necessidade de um mecanismo para resolver o problema da falta de competitividade do álcool em relação à gasolina, $20 \%$ consideram que após este problema de competitividade entre os dois produtos ser resolvido, o Estado nada mais teria de acrescentar ao setor, devendo deixá-lo ao livre mercado.

Dentro do grupo de 18 industriais, os restantes $17 \%$ não se posicionaram claramente a favor do Imposto Seletivo. Um deles salientou que, ao se discutir a questão da necessidade de um mecanismo de apoio ao álcool hidratado que substitua a PPE, está se partindo do pressuposto que as variáveis tecnológicas envolvidas na produção deste produto estão imobilizadas e que isso não é necessariamente a realidade.

Investimentos em novas tecnologias que visem maior produtividade $\mathrm{e}$ consequiente reduções de custo de produção do álcool, além de outros produtos derivados da cana-de-açúcar que aumentem a receita do setor (dentre eles a co-geração de energia elétrica) podem torná-lo competitivo frente a gasolina, conforme o comportamento dos preços do petróleo no mercado internacional. Reconhece porém que o momento que o setor está passando dificulta a adoção de novas tecnologias.

Os parlamentares ouvidos e a representante do governo também se posicionaram a favor de um mecanismo tributário de forma a viabilizar uso do álcool combustível em ambiente de livre mercado.

\subsubsection{As externalidades positivas da produção e uso do álcool combustível}

As questões das externalidades positivas do álcool combustível foram muito citadas para justificar a necessidade de intervenção do Estado neste mercado, de forma a incentivar sua produção e uso.

Existem externalidades positivas e negativas associadas à produção e ao uso do combustível de biomassa. Em relação às externalidades positivas, atualmente merece 
atenção especial o fato do álcool ser menos poluente que os combustíveis fósseis, principalmente quando se consideram os problemas de poluição nas grandes concentrações urbanas, que afeta a saúde das populações e o meio-ambiente.

Serodio et al. (1998, p.11) citam outros benefícios do combustivel renovável, dentre eles: os empregos diretos e indiretos gerados e mantidos; a possibilidade de se contar com a oferta do combustível alternativo aos derivados do petróleo, de origem renovável; a contribuição positiva para a balança comercial, pelas importações evitadas de petróleo e derivados".

Em relação às questões ambientais, desde a Conferência Mundial de Meio Ambiente e Desenvolvimento (UNCED), ocorrida em 1992, no Rio de Janeiro, que o problema da poluição atmosférica global associada às emissões de dióxido de carbono $\left(\mathrm{CO}_{2}\right)$, pela queima de combustíveis fósseis (carvão, petróleo e gás natural), desflorestamento e erosão do solo, tem ganhado importância na pauta de negociações dos países participantes da conferência. Naquela ocasião decidiu-se pela prevenção dos riscos do efeito estufa, que poderia implicar em alterações climáticas com graves conseqüências para diversos países.

A preocupação com o aumento do teor de $\mathrm{CO}_{2}$ na atmosfera está relacionado ao aquecimento global do planeta, devido ao "efeito estufa"lll, que pode provocar alterações do clima em diversas regiões, com impactos diferenciados em cada uma.

Em 1988, foi realizada uma conferência em Toronto, no Canadá, na qual foram estabelecidos alguns compromissos entre os países signatários dos protocolos emitidos, entre eles a limitação das emissões de $\mathrm{CO}_{2}$ para $20 \%$ abaixo do nível verificado em 1988 até o ano 2005, e o estabelecimento de um fundo mundial visando atender os objetivos propostos.

Em 1997, no Japão, foi assinado o Protocolo de Kyoto, no qual foram criados vários "mecanismos de flexibilização" de comércio de emissões de gases do efeito estufa, especialmente o carbono. Conforme Amaral (1999) esses mecanismos incluem o

\footnotetext{
${ }^{111}$ Segundo Ribeiro (1997), o efeito estufa é um fenômeno natural, que faz com que a temperatura da terra seja adequada à existência dos seres vivos. Porém, alguns gases emitidos acima das quantidades normais podem intensificar seu efeito, elevando a temperatura terrestre, com modificações climáticas importantes.
} 
"Comércio de Emissões", a "Implementação Conjunta (IC)"112 entre os países, e o "Mecanismo de Desenvolvimento Limpo".

O princípio adotado é que embora as emissões dos gases sejam feitas localmente, a sua grande dispersão na atmosfera tem efeito global, criando a possibilidade de adoção de práticas de comércio de emissões entre os países.

É interessante notar que as medidas globais para o controle e redução de emissões de $\mathrm{CO}_{2}$ criaram um novo mercado, o "comércio internacional de emissões", que pode beneficiar os países com baixos níveis de emissão e que tenham potencial para reduzí-la (incluindo o Brasil), através da negociação dos certificados de emissões.

Esta negociação é feita entre os países que tenham necessidade para reduzir seus níveis de emissão e já tenham esgotadas suas possibilidades internas, ou que considerem vantajoso investir na redução de emissões em países menos desenvolvidos (já que o custo dos projetos nestes países é menor).

O Brasil poderá contar com investimentos estrangeiros de países que tenham necessidade de diminuir seus níveis de emissão, contribuindo para a redução dos níveis de emissão globais. Neste contexto o país tem vantagens comparativas importantes relacionadas aos recursos naturais renováveis, como a energia hidrelétrica, carvão vegetal e álcool combustível.

Amaral (1999) salienta que o volume de recursos do mercado de carbono deverá atingir até 2010, segundo o Banco Mundial, valores entre US\$8 a US\$10bilhões de dólares, distribuídos entre os países onde os projetos serão implantados, sendo que

\footnotetext{
112 Conforme Ribeiro (1997) a IC envolve o acordo bilateral ou multilateral entre países com alto custo para reduzir a poluição ambiental e aqueles com menor custo. $O$ primeiro tratado do gênero foi firmado pela Noruega, Polônia e México, mediado pelo Global Environmental Facility. Os recursos foram provenientes de uma da renda gerada pela cobrança de uma taxa, na Noruega, sobre suas emissões de carbono.
} 
estes créditos poderão ser comercializados diretamente entre os países, por exemplo em bolsas de mercadorias e futuros ${ }^{113}$.

Macedo (1997) estimou a contribuição da agroindústria canavieira para a redução das emissões de carbono na atmosfera. Conforme o autor, para esta análise deve ser feito o balanço entre o aumento da taxa de $\mathrm{CO}_{2}$ na atmosfera decorrente do uso de combustíveis e insumos de origem fóssil utilizados na produção agrícola e industrial, e as reduções devido a substituição do etanol pela gasolina, e pela substituição do óleo combustivel pelo bagaço de cana tanto na produção de açúcar como de outros produtos industrias.

Além destas, as magnitudes das emissões de outros gases do efeito estufa relativos à produção, processamento e utilização da cana também são considerados, destacando-se: as emissões de metano oriundas da queima da cana-de-açúcar, da queima do bagaço nas caldeiras e da utilização de fertilizante; as emissões de $\mathrm{N}_{2} \mathrm{O}$ dos solos; e a comparação entre as emissões dos gases do efeito estufa ao se queimar etanol em substituição à gasolina. O balanço das emissões líquidas de $\mathrm{CO}_{2}$ equivalente em 1996 , está na tabela 11.

\footnotetext{
${ }^{113}$ Várias empresas do Brasil já apresentaram projetos à Câmara Americana de Comércio de São Paulo e ao Instituto de Políticas Públicas da Universidade de Colorado, que promoveram um encontro em São Paulo para discutir os tipos de projetos que poderiam candidatar-se aos recursos. Dentre elas estão a Companhia Açucareira Vale do Rosário, que quer captar fundos para expandir sua capacidade de cogeração energética a partir da queima de bagaço de cana ("Cresce briga pelo bilionário mercado de carbono". Gazeta Mercantil, p.A-9, 25/05/1999).
} 
Fabela 11. Balanço das emissões líquidas de $\mathrm{CO}_{2}$ (equiv.) devido a produção de cana-deaçúcar e utilização de etanol - 1996

\begin{tabular}{lc}
\hline & $10^{6}$ t C (equiv.)/ano \\
\hline Uso de combustíveis fósseis na agricultura & $+1,28$ \\
Emissões de metano (queima de cana-de-açúcar) & $+0,06$ \\
Emissões de $\mathrm{N}_{2} \mathrm{O}$ & $+0,24$ \\
Substituição da gasolina por álcool & $-9,13$ \\
Substituição de óleo combustível por bagaço (indústria de & $-5,20$ \\
alimentos e química) & $-12,74$ \\
\hline Contribuição líquida & \\
\hline
\end{tabular}

Fonte: Macedo (1997).

Nota-se que o balanço líquido das emissões na agroindústria canavieira e com o uso do etanol é bastante favorável, tendo sido evitadas emissões de $12,74.10^{6}$ toneladas de carbono no ano de 1996, que eqüivalem a $46,7.10^{6}$ toneladas de $\mathrm{CO}_{2}$, o que corresponde a aproximadamente $20 \%$ de todas as emissões de combustíveis fósseis no Brasil.

Desta forma, a mensuração das emissões permite quantificar as externalidades ambientais positivas decorrentes da produção e uso do álcool combustível, e abre possibilidades de entrada de recursos externos dos países com altos níveis de emissões que desejem investir no País através dos mecanismos de implementação conjunta.

Além das externalidades ambientais positivas que justificam a utilização do álcool combustível, um entrevistado salientou que a rede de distribuição de álcool no Brasil, com 26.000 postos de revenda do produto, é um patrimônio com um valor extraordinário, que aconteceu por razões históricas que dificilmente irão se repetir, já que sua criação somente foi possível devido a existência da Petrobrás, empresa estatal que detinha o controle sobre a distribuição e tancagem do produto, e que atendeu a uma determinação do Governo Federal. 
Desta forma, a criação de tal rede de distribuição dificilmente se repetirá em outro país que não tenha as mesmas características de planejamento centralizado que o País tinha na época do Proálcool, pois as empresas distribuidoras privadas relutam em criar ou ampliar a rede de distribuição de álcool sem ter demanda pelo produto. E a demanda por carros a álcool e pelo combustível não acontece se não existir uma rede de distribuição do mesmo.

Foi citado o exemplo dos Estados Unidos, que sendo o segundo maior produtor de álcool do mundo, tem somente 46 postos que oferecem o produto, e enfrenta resistência das distribuidoras para implantar uma rede ampla de postos que ofereça este combustível. Portanto, considera que o sucateamento e a eliminação da frota a álcool, com a perda deste patrimônio existente, representa um retrocesso quando se considera a necessidade de se substituir petróleo em grande escala em aproximadamente duas décadas.

Por outro lado, são identificadas também aspectos negativos na produção e uso do álcool hidratado combustível. Novaes ${ }^{114}$ cita que os adversários do programa listam uma série de inconvenientes, dentre eles: a monocultura da cana-de-açúcar, que ocupa uma área de $7,5 \%$ das terras cultiváveis do País; o agravamento das disparidades regionais (o Norte-Nordeste, que plantava 37,4\% da cana-de-açúcar em 1975, quando começou o programa, na data do trabalho detinha apenas $21 \%$, enquanto o Centro-Sul, principalmente São Paulo, passou de $62,6 \%$ para $78,9 \%$ naquele período); a concentração das áreas plantadas no Estado de São Paulo nas regiões de Ribeirão Preto e Campinas (65\% do total nacional); e as dívidas dos usineiros junto ao Banco do Brasil ( $\mathrm{R} \$ 4,4$ bilhões ao Banco do Brasil e mais $\mathrm{R} \$ 1,6$ bilhões à outras fontes).

Por sua vez, Rosa $(1996)^{115}$, ao avaliar o uso do álcool como combustível, em trabalho para o Centro de Pesquisa de Desenvolvimento Internacional do Canadá, concluiu que a agroindústria do álcool tem mais pontos positivos do que negativos e

\footnotetext{
${ }^{114}$ NOVAES, W. Proálcool não é filme de mocinho e bandido. Gazeta Mercantil, São Paulo, 05/03/1996, p.A-3.

${ }^{115}$ ROSA, L.P. Álcool deve ser mantido, revela estudo. Folha de São Paulo, São Paulo, 06/04/1996, Dinheiro, p.2.
} 
deve ser mantida, no contexto de uma política energética nacional. $O$ autor listou os prós e contras do álcool como combustível sob o ponto de vista social, ambiental, institucional, tecnológico, energético e econômico, e concluiu que, de 26 aspectos levantados, 11 foram considerados positivos para o álcool e oito negativos, e sete neutros.

Os pontos positivos foram a geração de emprego; a opção de outro combustível na matriz energética do País; ser fonte de energia renovável; a utilização do bagaço para a produção de energia elétrica; e a existência de uma política de preços (na época do estudo); a diminuição da poluição do ar em áreas urbanas; a redução do nível de $\mathrm{CO}_{2}$; o aumento de produtividade alcançado ao longo do tempo; a gaseificação do bagaço e o ciclo combinado com turbinas à gás.

Os pontos negativos foram condições de trabalho; o menor poder energético em relação à gasolina; os custos de produção mais elevados quando comparados com os preços dos derivados de petróleo; a relação entre açúcar e álcool; a situação de investimentos e financiamentos; a desregulamentação, que deixa ao sabor do mercado um produto que precisa de apoio governamental; a política do governo para o setor e a posição do Banco Mundial. O aspecto negativo levantado em relação ao meio-ambiente foi a produção de rejeitos.

Dentre os aspectos considerados neutros estão os salários, a comparação entre a produção de alimentos e de cana-de-açúcar e o uso do transporte público e privado.

Quanto ao aspecto social, a questão dos empregos gerados na agroindústria canavieira é um fator importante a ser considerado, posto que são gerados 1,1 milhão de empregos diretos (Serodio, 1999). No Estado de São Paulo, são 600.000 postos de trabalho, sendo que o piso salarial dos trabalhadores do setor é $70 \%$ maior que o salário mínimo. ${ }^{116}$

Porém, deve ser lembrado que uma parte significativa destes empregos está ameaçada, já que a proibição de queimadas como método de despalha impõe o uso de colhedeiras mecânicas, com conseqüente redução da mão-de-obra empregada.

\footnotetext{
${ }^{116}$ Informação UNICA, ano2, n 23, agosto de 1999.
} 
Considerando os aspectos teóricos envolvidos, as externalidades positivas existentes na produção e uso do álcool combustível são falhas de mercado que justificam a presença do Estado através da regulamentação social, já que os preços gerados em ambiente de livre mercado, sem considerá-las, podem ser insuficientes para que os retornos dos investimentos realizados sejam apropriados, levando a uma produção subótima.

A primeira questão a ser esclarecida é se a sociedade seria realmente beneficiada com a inclusão deste produto na matriz energética brasileira. ${ }^{117} \mathrm{Se}$ confirmada a opção pelo uso do álcool, as políticas públicas devem contemplar tanto a promoção da oferta adequada como o incentivo à demanda pelo produto.

Em relação à oferta, os entrevistados consideram que a formação dos estoques estratégicos pelo governo é essencial, tanto para garantir o abastecimento, como para ser usado como instrumento de controle de preços praticados no mercado.

Eles salientaram que as compras de álcool para a formação dos estoques do governo poderiam ser feitas por um preço de referência fixado por ele (e compatíveis com os custos de produção), que desovaria os estoques conforme as necessidades do mercado, regulando a oferta aos níveis da demanda, de forma a controlar os preços do mercado.

Segundo os entrevistados, outro fator que torna a formação e manutenção de estoques estratégicos do governo essencialmente importante, e requer ações planejadas ao longo da cadeia para evitar o descompasso entre a oferta e a demanda, é o fato do álcool ser obtido de matéria prima agrícola (sujeita às intempéries climáticas) de ciclo longo. Desta forma, diferentemente dos combustíveis fósseis, cuja produção pode ser aumentada ou reduzida em espaço de tempo relativamente curto, a cana-de-açúcar, e portanto a fabricação do álcool, requer planejamento de longo prazo.

\footnotetext{
117 A matriz energética define a utilização das várias formas de energia: combustíveis derivados do petróleo, do gás natural, de biomassa, energia elétrica, e pode inclusive ser diferente para cada Estado, conforme a disponibilidade dos combustíveis em cada região.
} 
Além disso, para ressaltar a importância dos estoques estratégicos, foi citado que não existem outros países que produzam as quantidades necessárias para abastecer o mercado de álcool hidratado em caso de falta de produto.

Um dos entrevistados salientou que a formação dos estoques estratégicos poderia substituir a política do suporte ao álcool atualmente existente, e que traria menos gastos ao Estado, já que desta forma o governo estaria comprando o produto, e quando fosse efetuada a venda ele teria o recurso de volta, arcando com os custos de estocagem e de oportunidade do capital.

Algumas considerações no que se refere à formação dos estoques estratégicos pelo governo merecem ser feitas. Embora a legislação existente (Lei № 8.176 , de fevereiro de 1991, que instituiu o Sistema Nacional de Estoques de Combustíveis) ${ }^{118}$ estipule a formação dos estoques estratégicos do governo, é necessário avaliar se esta é a opção economicamente mais eficiente.

A questão é comparar os custos envolvidos na formação dos estoques do governo e a eficácia das condutas intervencionistas do Estado, com a utilização de outros mecanismos possíveis, como por exemplo fornecer suporte à formação de estoques privados.

Existem outros produtos (como, por exemplo, arroz, feijão, trigo, etc.) para os quais também existe a legislação que estabelece a formação de estoques do governo, sendo que para alguns deles também não existem quantidades suficientes no mercado externo para abastecer o mercado interno. Porém, nestes casos o Governo Federal vem criando alternativas de sustentação aos preços que se enquadram ao seu orçamento e reduzem seu envolvimento operacional.

Conforme Barros (1999), dentre estes mecanismos estão as cédulas do produtor rural (CPR), venda de opções sobre o mercado físico, e o Programa de Escoamento de

\footnotetext{
${ }^{118}$ Conforme visto anteriormente, cabe à ANP a responsabilidade de fiscalizar o adequado funcionamento do Sistema Nacional de Estoques de Combustíveis e o cumprimento do Plano Anual de Estoques Estratégicos de Combustíveis (Lei № 9.478, de agosto de 1997). Por sua vez, a Medida Provisória № 1690-1, de junho de 1998, estabelece que o abastecimento nacional de combustíveis é considerado de utilidade pública e estabelece as sanções administrativas aos infratores das normas estabelecidas referentes às atividades relacionadas ao mercado de combustíveis.
} 
Produção (PEP). Embora se reconheça que tais programas precisam de aperfeiçoamento, não devem ser desconsiderados o desenvolvimento e utilização de novos instrumentos de intervenção setorial no mercado de álcool mais condizentes com o cenário político econômico estabelecido.

Em relação à questão do abastecimento, a flexibilidade entre a produção de açúcar e de álcool, que é uma vantagem por permitir que os empresários alternem sua produção conforme os preços relativos dos produtos no mercado doméstico e internacional, é também uma questão importante que merece bastante atenção.

Conforme os entrevistados, no caso de necessidade do direcionamento da produção para álcool, de forma a assegurar o abastecimento dada uma retomada do Programa, isto poderia ser feito pela própria iniciativa privada, através da autogestão, ou pelo Estado, através dos instrumentos de política pública disponíveis, tais como a imposição de tarifas à exportação de açúcar.

Conforme salientado anteriormente, embora a Portaria № 46, de abril de 1997 tenha zerado a alíquota do imposto sobre a exportação, ela ainda existe, e o governo pode alterá-la até o limite de $40 \%$, conforme suas necessidades (por exemplo para abastecer o mercado doméstico de açúcar, ou para um direcionamento do açúcar de exportação para álcool).

Porém, conforme já discutido, não se pode menosprezar as falhas de governo, que fazem com que suas ações nem sempre sejam as mais adequadas, nem as pressões daqueles agentes que dependem do mercado externo para a execução de suas estratégias, que certamente influenciarão as decisões políticas referentes ao imposto de exportação.

Em relação às ações do Estado visando aumentar o uso do álcool combustível, considerando-se que existe a intenção de estimular o uso do combustível renovável dadas suas externalidades positivas, existem diversas alternativas, que incluem tanto incentivos ao uso do álcool combustível como a taxação dos combustíveis de origem fósseis. 
Os incentivos ao uso do álcool podem ser feitos pelas diversas esferas da administração pública (municipais, estaduais e federais), sendo que algumas já estão sendo implementadas em alguns estados e municípios. ${ }^{119}$

As ações municipais podem incluir por exemplo, a exclusão dos veículos movidos com este combustível dos rodízios implementados nos grandes centros urbanos que visam reduzir o nível de poluição do ar, e a devolução da parcela do IPVA referentes aos municípios. Os governos estaduais podem reduzir o ICMS sobre o álcool hidratado e dar isenção ou redução do IPVA dos carros a álcool. Na esfera Federal, exemplos de políticas são (algumas já implantadas): adoção de frotas do governo a álcool, aumento do teor da mistura de anidro na gasolina; aprovação da adição de anidro no diesel, isenção de IPI dos carros a álcool para táxis e locadoras; e a adoção do imposto seletivo sobre os combustíveis.

Considerando as questões ambientais, conforme Carlton \& Perloff (1991) existem duas formas de intervenção do governo para reduzir a poluição: a primeira é restringindo a produção causadora da poluição, a segunda é impondo uma taxa igual ao custo marginal da poluição às firmas poluidoras, que funciona como uma internalização do custo social da externalidade ${ }^{120}$.

Desta forma a imposição de uma tarifa sobre a fonte causadora da poluição (neste caso os combustíveis fósseis), que poderia ser a adoção do imposto seletivo, com uma taxação maior sobre a gasolina, seria uma forma de reduzir seu uso (e reduzir as emissões de $\mathrm{CO}_{2}$ ), e ao mesmo tempo incentivar o uso do combustível menos poluente.

\footnotetext{
119 No Estado de São Paulo, a assinatura do "Pacto pelo Emprego", em agosto de 1999, formalizou compromissos assumidos entre os diversos agentes da cadeia visando resgatar a credibilidade do álcool combustível e fortalecer uma atividade econômica importante para o Estado.

${ }^{120}$ Conforme os autores, a partir da emissão do Clean Air Act nos Estados Unidos, em 1970, que estabeleceu uma redução substancial nos níveis de emissões derivados da queima de combustíveis e dos processos industriais, o total de partículas suspensas foi reduzida em 13,4\% entre 1970 e 1977, e o nível de dióxido de enxofre diminuiu $15,7 \%$ no período.
} 


\subsubsection{O desequilíbrio competitivo entre produtores de álcool e distribuidoras de combustível}

Diversas questões relacionadas ao mercado de distribuição de combustíveis, que podem requerer a ação do Estado por indicarem a existência de falhas de mercado, foram levantadas pelo grupo de industrias, parlamentares e governo, dentre elas: a estrutura concentrada do mercado de distribuição, a evasão fiscal, a qualidade do combustível, e a agência governamental responsável pela regulação da atividade.

Iniciando com a questão da estrutura do mercado de distribuição, para verificar a diferença competitiva existente entre produtores de álcool e distribuidores, é interessante lembrar que até 1990 o mercado de distribuição era fechado e composto somente pelas distribuidoras afiliadas ao Sindicom, sendo que as barreiras existentes para a entrada de novas distribuidoras no mercado eram oriundas da própria legislação existente, que era bastante rígida no que se referia aos requesitos para o cadastramento das distribuidoras nos órgãos competentes.

A estrutura concentrada do mercado de distribuição e o conseqüente desequilíbrio competitivo com os produtores de álcool (de um lado estão cinco grandes distribuidoras representadas pelo Sindicom - Esso, Texaco, Shell, Ipiranga e BRPetrobrás -, que detém $80 \%$ do mercado, e várias distribuidoras pequenas responsáveis pelo restante do mercado, e do outro lado aproximadamente 320 produtores de álcool) não era evidente quando o setor vivia sob intervenção porque as negociações eram feitas na mesa de comercialização, entre dois agentes com forças equilibradas, a Petrobrás e o Sindicom.

Porém, com a desregulamentação e a abertura do mercado de distribuiçẫo esta desigualdade tornou-se clara. Segundo um dos entrevistados, antes da desregulamentação do mercado sucroalcooleiro, a principal preocupação dos produtores de açúcar e álcool era com a super oferta e com o desequilíbrio de competitividade entre as empresas do próprio setor, que muitos achavam que seria resolvido a partir da liberação, já que esta privilegiaria os mais eficientes e adequaria a produção à demanda existente. 
Além disso, após a desregulamentação, esperava-se que as vendas de álcool fossem feitas através de contratos entre os produtores de álcool e as distribuidoras, resolvendo os problemas de alguns produtores que estavam "amarrados" na mesa de comercialização, cujo sistema possibilitava o fornecimento de informações distorcidas, em detrimento destes produtores.

Contudo, com a liberação do mercado emergiram dois problemas que até então não estavam evidentes: a competição do álcool com a gasolina liberada (comentado anteriormente) e o desequilíbrio inter-setorial, decorrente da alta concentração existente no setor de distribuição.

Dos 18 industriais entrevistados que se posicionaram sobre a diferença competitiva no mercado de distribuição foram identificados quatro grupos. O primeiro, composto por $45 \%$ dos entrevistados, salienta que embora exista uma preocupação com o poder das grandes distribuidoras, agrupadas no Sindicom, o maior problema surgiu justamente com a abertura do mercado de distribuição, e com as inúmeras empresas que surgiram, das quais muitas trabalham na ilegalidade.

Já o segundo grupo, composto por aproximadamente 33\% dos industriais, salientou que as dificuldades advém do enorme poder das grandes distribuidoras em relação aos produtores de álcool; o terceiro grupo, representando $11 \%$ dos industriais acredita que ambas trabalham de forma prejudicial ao setor produtivo; e por fim, os $11 \%$ industriais que fazem parte do quarto grupo, não creditam os problemas enfrentados às distribuidoras, e sim ao excesso de oferta existente.

Iniciando a análise com o primeiro grupo de industriais (que considera que atualmente o maior problema enfrentado no mercado de distribuição decorre justamente da abertura feita pela ANP, que procurava torná-lo mais competitivo), eles reconhecem a importância das pequenas distribuidoras, de forma a diminuir o poder das grandes agrupadas no Sindicom, mas salientam que a falta de uma regulamentação na época da abertura, e as dificuldades que as autoridades fazendárias e a ANP encontram para fiscalizar o setor trouxeram graves problemas aos produtores de álcool e consumidores do produto. 
Embora estes entrevistados não tenham identificado especificamente quais as novas empresas que eles consideram nocivas ao setor, os inúmeros problemas citados foram creditados às várias distribuidoras pequenas e independentes, dentre eles:

- sonegação fiscal;

- empresas fantasmas;

- mercado clandestino de álcool combustível;

- indústria de liminares.

- adulteração de combustíveis;

Em relação aos cinco primeiros problemas, eles argumentam que as empresas grandes, cujos custos são mais altos e trabalham na legalidade, recolhendo os impostos devidos e oferecendo combustíveis de qualidade, acabam sofrendo com a concorrência desleal de inúmeras empresas menores, que derrubam os preços nas bombas, forçando as grandes distribuidoras a praticarem preços menores para evitar a perda de market-share, com conseqüente achatamento dos preços pagos aos produtores de álcool. Desta forma, eles consideram que a sonegação e adulteração dos combustíveis como os grandes fatores que justificam a queda de renda do setor sucroalcooleiro.

Foi salientado que a alta carga tributária na comercialização dos combustíveis é um fator de incentivo à sonegação fiscal, possível graças a falta de fiscalização pelas autoridades fazendárias, que possibilita que algumas distribuidoras e postos deixem de recolher ICMS, PIS ou Cofins.

O álcool hidratado é considerado pelos entrevistados a melhor opção de sonegação entre os combustíveis ${ }^{121}$ : os tributos incidentes sobre este produto são da ordem de $31,1 \%$, sendo que $1,8 \%$ é recolhido pelas unidades produtoras e $29,3 \%$ pelas distribuidoras, tornando a fiscalização bastante difícil. Por usa vez, a incidência dos impostos sobre a gasolina e o diesel é feita quase que totalmente na refinaria.

${ }^{121}$ Segundo estimativas do Sindicom, a arrecadação de impostos do álcool hidratado são da ordem de $\mathrm{R} \$ 2$ bilhōes de reais por ano, havendo um aumento potencial de $\mathrm{R} \$ 600$ milhões, que é o montante sonegado (R $\$ 222$ milhões de reais de PIS/COFINS e R $\$ 382$ milhões de reais de ICMS). 
Como os tributos chegam a representar até $35 \%$ do preço final da gasolina e do álcool e até $20 \%$ no diesel, esta diferença é crucial na questão de competitividade entre as empresas do setor, já que implicam em preços muito diferenciados entre as distribuidoras e nas bombas, sendo um dos fatores citados pela importante alteração da participação das distribuidoras no mercado de combustíveis. A evolução da participação das distribuidoras nas vendas de álcool hidratado pode ser apreciadas na tabela $\downarrow 1$.

Tabela 12. Evolução da participação percentual das distribuidoras no mercado de álcool hidratado

\begin{tabular}{cccc}
\hline Ano & \multicolumn{3}{c}{ Participação Distribuidoras (\%) } \\
\hline & Sindicom & Outras & Mercado Clandestino \\
1995 & 95,4 & 4,6 & 0 \\
1996 & 91,9 & 8,1 & 0 \\
1997 & 85,3 & 11,0 & 3,8 \\
1998 & 64,5 & 12,4 & 23,2 \\
1999 & 56,0 & 20,4 & 23,6 \\
\hline
\end{tabular}

Fonte: Sindicom ${ }^{122}$.

Nota-se pela tabela 11 que a participação das distribuidoras no mercado de álcool hidratado no período considerado se alterou drasticamente ${ }^{123}$ : a parcela das distribuidoras afiliadas ao Sindicom reduziu-se em 41,3\%; a das outras distribuidoras aumentou em aproximadamente $343 \%$, e o mercado clandestino de álcool hidratado passou a representar 23,6\% das vendas em 1999.

Por outro lado, o grande crescimento apresentado pelas novas distribuidoras não pode ser explicado somente pela concorrência desleal. Existe uma diferença de competitividade de algumas em relação às tradicionais, já que além de operarem com

\footnotetext{
122 "Proposta de comercialização de álcool hidratado". Sindicom, março de 1999.

${ }^{123}$ É importante ressaltar que trata-se de um mercado que movimenta ao redor de US $\$ 25$ bilhões de dólares por ano e mais de 5 bilhões de litros de óleo diesel, gasolina e álcool por mês (Gazeta Mercantil, 05/08/1998, p.C-1).
} 
custos fixos comparativamente menores (suas instalações e infra-estrutura são bastante enxutas), são empresas pequenas, bem administradas, com distribuição regional, e vantagens logísticas.

Além disso, a atual legislação permite que estas distribuidoras entreguem seu produto nas redes de postos com bandeira, ou seja, elas não arcam com todos custos envolvidos na instalação e manutenção da rede de postos e da marca (marketing, contratos de bandeira com os postos autorizados, etc.), e acabam por "invadir" os postos com bandeira das distribuidoras tradicionais.

Outros fatores levantados pelos entrevistados que justificam a alteração do market-share no mercado de distribuição são as liminares judiciais devido às "brechas" existentes na lei. As liminares ${ }^{124}$ visam impedir que a Petrobrás fature o valor do ICMS junto com a nota fiscal da venda dos combustiveis, e permitem às empresas pagar o ICMS somente depois da venda do combustível para o consumidor, e não no momento da compra do produto na refinaria, resultando, conforme estimativas do Sindicom, preços $12 \%$ inferiores aos detentores das mesmas.

No Estado de São Paulo, todas as liminares já foram suspensas por determinação do Tribunal de Justiçá, que deu ganho de causa à Procuradoria da Fazenda numa ação contra as distribuidoras de combustíveis independentes, que não queriam recolher o ICMS nas vendas de combustíveis por substituição tributária, conforme determina a legislação. No entanto, nos Estados do Espírito Santo, Pernambuco, Pará, Rio de Janeiro e Maranhão, até abril de 1999, a Justiça continuava concedendo ou mantendo liminares para a não retenção de ICMS nas vendas das refinarias às distribuidoras.

A questão da adulteração de combustíveis citada pelos entrevistados será analisada na próxima seção.

Portanto, este grupo credita grande parte da queda da renda observada no setor sucroalcooleiro à forma como ele foi liberado, achando que há necessidade de maior

\footnotetext{
${ }^{124}$ As empresas detentoras das liminares alegam que a cobrança é ilegal por dois motivos: a substituição da figura do recolhedor de tributo e a proibição legal no caso de vendas interestaduais de combustíveis.
} 
atuação por parte do governo, no que se refere à fiscalização (da qualidade do produto e dos tributos) de forma a evitar e proibir os problemas levantados.

Foi citado também que deveria haver uma regulamentação impondo a contratação formal de certa quantidade da demanda estimada de álcool, inclusive por garantias de abastecimento. Na safra 1998/99 o mercado foi abastecido com compras feitas praticamente $100 \%$ no mercado "spot", cujos preços estavam bastante deprimidos devido à super oferta existente.

Porém, a imposição da contratação formal de certa parcela de álcool combustível através de regulamentação provavelmente será uma medida juridicamente questionável, dada a Constituição Federal de 1988. Parece claro que para ambas as partes os contratos de longo prazo trariam benefícios (os produtores poderiam planejar sua produção, e distribuidoras teriam garantia de abastecimento nos seus postos), porém esta decisão deve partir dos próprios agentes envolvidos na transação.

Já o segundo grupo, composto por aproximadamente 33\% dos industriais, salientou que as dificuldades encontradas no setor de distribuição advém do enorme poder das grandes distribuidoras em relação aos produtores de álcool, as quais ditam os preços no setor.

Eles salientam que existe um oligopólio claro neste mercado, que se aproveitou da super-oferta existente para achatar os preços do álcool, havendo uma transferência enorme de renda dos produtores para as distribuidoras, já que os preços baixos não foram repassados ao consumidor.

O terceiro grupo, representando $11 \%$ dos industriais, acredita que tanto as grandes como as pequenas se apropriaram da renda dos produtores devido aos problemas anteriormente levantados.

Finalmente, os $11 \%$ industriais que fazem parte do quarto grupo não creditam os problemas enfrentados às distribuidoras, e sim ao excesso de oferta existente. Eles salientam que nenhuma regulamentação por parte do governo (incluindo a obrigatoriedade de contratação formal de álcool) vá funcionar se a oferta não estiver 
adequada à demanda. Eles acham que o mercado funcionará bem quando as políticas de incentivo à demanda proporcionarem o equilíbrio entre a oferta e a demanda.

Em relação à estrutura concentrada existente, alguns salientaram que não é possível afirmar se a conduta das grandes distribuidoras foi lesiva ao setor, devido ao pouco tempo de funcionamento do regime de livre mercado.

Algumas considerações sobre as questões apresentadas pelos entrevistados são importantes para a identificação de falhas de mercado e da necessidade de intervenção do Estado no setor de distribuição.

Iniciando com o problema da alta concentração existente na distribuição do álcool hidratado, verificamos que embora a participação das empresas associadas no Sindicom tenha se reduzido acentuadamente (antes da liberação do mercado era de $100 \%$; entre 1995 e 1999 passou de $95,4 \%$ para 56\%), ela ainda é suficientemente alta para que não se desconsidere a possibilidade de exercício do poder de mercado.

Conforme visto anteriormente, quando o poder de monopólio deriva de estruturas de mercado oligopolistas, a ação do Estado deve ser no sentido de adotar uma política antitruste, de forma a impedir o exercício do poder de monopólio e adoção de estratégias anticompetitivas, através da aplicação da legislação pertinente.

Desta forma, constatado o abuso econômico, a ação governamental apropriada deve ser feita pelos órgãos competentes, no caso o Conselho Administrativo de Defesa Econômica (CADE).

Especificamente em relação ao setor de combustíveis, a Lei № 9.478 , de agosto de 1999, estabelece que, quando no exercício de suas atribuições a agência reguladora do setor de combustíveis - a ANP - tomar conhecimento de fato que configure ou possa configurar infração da ordem econômica, deverá comunicar ao CADE para que este adote as medidas cabíveis, conforme prescrito pela legislação.

Quanto à legislação para tratar da prevenção e repressão às infrações contra a ordem econômica, o artigo $20^{\circ}$ da Lei № $8.884 / 94$, de junho de 1994, considera infração da ordem econômica "exercer de forma abusiva posição dominante do mercado", ou seja, para que deter certa fatia de mercado seja considerada uma infração da ordem 
econômica, ela deve ser tal que iniba a concorrência e que permita o exercício do poder de mọnopólio.

Conforme a referida lei, esta posição dominante corresponderia a uma fatia de $30 \%$ do mercado. Porém, um "market-share" de $30 \%$ não implica em exercer poder de monopólio, já que não existe na teoria econômica uma base sólida para se estipular um grau de concentração de mercado ideal, mesmo sob a hipótese de concentração-coalisão em estruturas oligopólicas, que evitasse o poder de monopólio.

Desta forma, ao se analisar a questão de "posição dominante" devem ser analisados outros fatores conjuntamente, tais como as condições básicas de oferta e de demanda, a existência de barreiras à entrada, a caracterização dos ativos envolvidos e a questão das especificidades, etc.

Outra forma de ação é analisar a conduta dos agentes (neste caso das distribuidoras), por exemplo: se as firmas estão adotando práticas predatórias que visam eliminar a concorrência (acordos de fixação de preços, preços predatórios, discriminação de preços visando eliminar concorrente, vendas casadas, etc), ou estabelecendo estratégias visando impedir entrada de novos concorrentes, que implicariam no afastamento do desempenho do mercado em relação ao ideal competitivo. Constatado o exercício de poder de mercado, o Estado, através do CADE, deve tomar ações apropriadas com base na legislação em vigor.

Por outro lado, a reviravolta ocorrida no mercado de combustíveis (que passou de 10 distribuidoras para 169 em menos de 5 anos), tende a aumentar com o fim do monopólio da Petrobrás, com a provável entrada de grandes companhias petrolíferas estrangeiras que virão para o Brasil operar na exploração e produção de petróleo e gás, como por exemplo Total, Elf, Chevron e YPF.

Desta forma, neste novo cenário, no médio prazo a concorrência entre as empresas distribuidoras de combustíveis irá se fortalecer, alterando as participações relativas das empresas tradicionais do setor e reduzindo seu poder de mercado. Contudo até que a modificação da estrutura de mercado e a competição no setor aumente, fica 
caracterizada uma falha de mercado que merece atenção da agência reguladora oficial do setor (ANP).

Diversas notícias têm sido veiculadas na mídia no que se refere aos problemas de adulteração de combustíveis e de sonegação fiscal. Sem entrar no mérito relativo à eficácia das ações tomadas pela ANP, em setembro de 1999 foram lacradas vinte e três bases de distribuidoras de combustiveis (responsáveis por 3\% do abastecimento interno), após a constatação de irregularidades, como a falsificação de certidões negativas apresentadas à Receita Federal (para comprovação de que a empresa não tem débitos com a Receita Federal, como Imposto de Renda, ICMS, PIS e COFINS).

Em relação à atuação da ANP no que se refere ao álcool combustível, dos 16 representantes do grupo dos industriais que se posicionaram a respeito, aproximadamente $50 \%$ consideram que deveria existir uma agência reguladora específica para o álcool. Eles salientaram que o álcool na ANP tem caráter residual, já que a agência estaria muito comprometida com os combustíveis fósseis, sendo o álcool o único empecilho para o domínio completo daqueles combustíveis, existindo, portanto, um conflito de interesses dentro da própria agência.

O restante dos industriais acredita que a própria ANP está apta para lidar com as questões de regulação e fiscalização do mercado de combustíveis - incluindo o álcool porém reconhecem que é preciso que se dê mais atenção ao produto dentro da agência. Alguns acreditam que o problema é a falta de definição da política energética a ser seguida e o papel do álcool dentro da matriz energética, que direcionaria a própria ação da agência.

Porém, conforme salientado anteriormente, verificada a falha de mercado decorrente da estrutura de mercado concentrada, e a incapacidade do mercado em alocar os recursos eficientemente, não devem ser negligenciadas as falhas inerentes à ação dos governos, devendo ser consideradas outras alternativas para a solução dos problemas.

O uso das câmaras setoriais, que seriam fóruns para se identificar as áreas de cooperação entre os segmentos e ajudar na solução dos conflitos distributivos existentes, com o governo no papel de mediador, pode ser uma delas neste caso também. 
Além desta, as soluções dos problemas através da união dos agentes, de forma a aumentar o poder de barganha para realização de uma negociação conjunta, pode ser uma solução mais eficiente e menos custosa que a ação estatal.

Ou seja, a organização do setor e a negociação conjunta em melhores condições com as distribuidoras grandes trariam mais benefícios para todos do que a negociação individual com as pequenas, que estão praticando preços aviltados. Neste sentido, os produtores deram um grande salto organizacional e criaram a Bolsa Brasileira de Álcool (BBA), melhorando a questão da paridade das duas classes nas negociações.

\subsubsection{A criação da Brasil Álcool e da Bolsa Brasileira de Álcool}

Conforme visto anteriormente, a Bolsa Brasileira de Álcool (BBA), funciona como uma central de comercialização, permitindo que os produtores negociem em bases mais equilibradas com as distribuidoras.

Porém, da mesma forma que as distribuidoras agrupadas no Sindicom podem exercer seu poder de mercado por deterem parcela considerável do mercado, os produtores associados na BBA passam a dominar a comercialização de $78 \%$ do álcool da região Centro-Sul (78\%), o que requer reflexão sobre o assunto.

Tanto a criação da Brasil Álcool quanto da Bolsa Brasileira de Álcool foram precedidas de consultas ao CADE (que está analisando a questão). Segundo um dos entrevistados, diversos argumentos foram apresentados ao CADE para justificar a criação da BBA, e para mostrar que a intenção da empresa não é o de exercer o poder de mercado, nem de elevar os preços a níveis inaceitáveis, e sim uma forma de auto-gestão para substituir os mecanismos estatais anteriormente existentes. Dentre os argumentos citados ao CADE estão:

- que a união das empresas tem o sentido de proteção às dificuldades de comercialização encontradas no livre mercado, principalmente quando se considera que a produção é feita em 6 meses para ser vendida em 12 meses; 
- que existe um competidor para o produto (a gasolina), que domina o mercado, que tem vantagens competitivas em relação ao álcool e que não permite a prática de preços abusivos para o álcool;

- que existe o interesse em estimular o carro a álcool e o consumo deste combustível (já que o mercado de álcool é essencial para a agroindústria sucroalcooleira), e que para isso é essencial garantir para o consumidor um produto de qualidade, com oferta estável ao longo do ano, requerendo a união dos produtores para melhorar a eficiência da comercialização do produto.

Ao se analisar teoricamente $o$ acordo feito entre as empresas para a comercialização conjunta do álcool e a caracterização da formação de um cartel, já que o poder de barganha das mesmas aumentou consideravelmente, algumas considerações devem ser feitas.

Best (1990) argumenta que a cooperação entre as firmas ou os cartéis de estabilização não devem ser vistos somente como forma de conseguir poder de mercado - embora normalmente o seja - mas também como forma de promover o desenvolvimento de longo prazo de um setor.

Segundo o autor, os acordos entre as empresas, fusões e cartéis, portanto, podem e devem ser aceitos quando são estabelecidos objetivando a racionalização da produção ou as reduções negociadas da capacidade produtiva para evitar a concorrência predatória. Porém, o autor salienta que estes tipos de acordos devem ser estabelecidos por período limitado de tempo no contexto de uma política industrial, visando o desenvolvimento de longo prazo do setor.

Por outro lado, o autor reconhece que a cooperação entre as firmas pode, tal como prediz a teoria econômica tradicional, prejudicar o desempenho do setor, sendo que a questão central é estabelecer meios de cooperação que gerem benefícios comuns para as firmas envolvidas sem prejudicar o desempenho econômico, o que se torna verdade quando a cooperação é o resultado de uma resposta a uma pressão competitiva. 
Desta forma, a cooperação entre as firmas deve ser sustentada por uma base institucional pública ou privada, que desenvolva a identidade coletiva e promova incentivos à cooperação de modo a evitar as ações oportunistas dos "free-riders".

Ao analisarmos os argumentos apresentados ao CADE para a criação da BBA identificamos alguns pontos levantados por Best (1990) que podem justificar a união dos produtores.

Primeiramente, a questão da pressão competitiva e a prática dos preços predatórios. O fato da produção ser feita ao longo de seis meses para ser vendida em doze meses, implicando em elevados custos de estocagem do produto, aliado às necessidades maiores de recursos pelos produtores justamente nos meses de safra, é um indicativo da necessidade de um mecanismo de controle sobre a comercialização da oferta do produto.

Sem um gerenciamento sobre a comercialização, haverá uma concorrência predatória entre os produtores (já que os mais necessitados podem ofertar quantidades maiores e a preços menores), o que pode levar a uma queda generalizada da renda de todo o setor, podendo até inviabilizar a atividade. Para amenizar este problema, a empresa pode atuar administrando os estoques e otimizando sua distribuição ao longo do ano.

Portanto, a BBA pode ser uma forma de cooperação entre os produtores de álcool de forma a enfrentar a pressão competitiva enfrentada, tanto no que se refere a estrutura de mercado concentrada do mercado de distribuição, como à prática de preços predatórias oriunda do excesso de álcool existente e da necessidade de recursos dos produtores.

Porém, esta união dos produtores em torno da BBA, além de merecer atenção especial da agência reguladora do setor (que deve estar atenta a questão do desempenho econômico), deve durar, conforme requerido na consulta ao $\mathrm{CADE}$, somente enquanto persistirem os problemas levantados. 
A questão do abastecimento é outro fator que requer uma interação grande entre os participantes (principalmente quando se considera a desregulamentação do setor) e também com o Estado, que pode ser facilitada através da Brasil Álcool.

Desta forma, a Brasil Álcool pode contribuir para que os produtores possam cumprir as responsabilidades de abastecimento assumidas, e pode facilitar a articulação e sobrevivência do setor num sistema de auto-gestão.

Em relação ao desempenho econômico, a questão central é o acompanhamento das atividades das empresas, de forma a identificar sua conduta. No periodo de funcionamento das empresas ${ }^{125}$, é necessário que a ANP avalie as estratégias adotadas, e no caso de práticas de preços predatórias, ou outro tipo de conduta que prejudique o desempenho econômico, a agência informe ao CADE para que as medidas cabíveis sejam tomadas.

Em relação a necessidade de uma base institucional que desenvolva a identidade coletiva e promova incentivos à cooperação de modo a evitar as ações oportunistas dos "free-riders", este parece ser o grande desafio das empresas criadas.

Embora ambas empresas tenham uma base jurídica sólida, com sistema de punições no caso de quebra contratual, um setor que durante 60 anos viveu sobre a égide do Estado, que atuava como mediador de conflitos, e que ao longo de sua história foi marcado por interesse distintos (por exemplo entre os produtores do Norte/Nordeste e do Centro-Sul, ou entre as destilarias do Pro-álcool e as usinas tradicionais) agora necessita organizar sua produção de modo a adequá-la ao mercado, e ao mesmo tempo compatibilizar os interesses dos diversos produtores.

\subsubsection{O problema de assimetria de informação}

Outra falha de mercado importante levantada pelos entrevistados (e confirmada pelas notícias constantemente veiculadas na mídia), que surgiu após a abertura do mercado de distribuição, é o problema de adulteração de combustíveis.

\footnotetext{
125 Ambas pediram autorização ao CADE para funcionar sob determinados períodos: um ano, com possibilidade de prorrogação para dois no caso da BBA, e três anos no caso da Brasil Álcool.
} 
Visando baratear o custo da gasolina, diversos tipos de fraudes foram relatadas, que não são perceptíveis pelo consumidor na hora da compra e causam sérios problemas futuros, dentre elas a mistura de álcool anidro em excesso (acima dos $24 \%$ permitidos por lei), ou de produtos químicos e solventes na gasolina.

Esta gasolina adulterada pode causar problemas de corrosão nas peças do motor, ocasionando alto consumo, defeitos no motor, entupimento e falhas na bomba de combustível.

Tanto esta questão, como as portarias existentes que permitem que os postos com bandeira comprem álcool de qualquer distribuidora para ofertar aos consumidores finais, fazendo que o produto adquirido nos postos revendedores com bandeira não necessariamente tenha a procedência e a qualidade da marca ostentada pelo posto, são problemas de assimetria de informação, que é uma falha de mercado que pode ser corrigida através da regulamentação social.

Sob o aspecto teórico, os problemas de moral hazard (risco moral) são decorrentes da assimetria de informação entre as partes, que impede que os mecanismos de mercado operem eficientemente, e requerem ação governamental porque se as informações não forem suficientes, as decisões dos agentes se afastarão da ideal.

Desta forma, a comercialização dos produtos sujeitos à assimetria de informação, como é o caso dos combustíveis, requer a regulamentação estatal devido aos riscos que a informação assimétrica ou imperfeita impõe aos consumidores.

É interessante notar que os itens 6.23 e 6.24 do Pacto pelo Emprego do Negócio Sucroaicooleiro do Estado de São Paulo procuram corrigir estes problemas de assimetria de informação, tanto no que se refere ao problema da qualidade como da identificação do produto no posto.

Estes itens, que referem-se aos esforços de competência do Governo Federal, estabelecem primeiramente a necessidade de normas para a comercialização do álcool hidratado no varejo, no sentido de que os postos que optarem por serem identificados com determinada bandeira, somente poderão comercializar o álcool proveniente daquela distribuidora, e os que optarem por mais de um fornecedor do produto, deverão segregar 
os conjuntos de bombas e tanques por fornecedor, de forma a não misturar os produtos de diferentes origens.

Além disso, que o Governo Federal faça esforços no sentido de garantir que o álcool hidratado seja adquirido somente de distribuidora devidamente autorizada pela ANP, em estrita observância à legislação aplicável à sua atividade, em especial o artigo 66 do Código de Defesa do Consumidor e do artigo 194 do Decreto Lei №7.903.

A legislação existente pertinente às questões de comercialização, distribuição e fiscalização dos combustíveis é bastante ampla. O Decreto $\mathrm{N}^{\mathrm{O}} 2.455$, de janeiro de 1998 , estipula que cabe à ANP a regulação e autorização para o exercício das atividades relacionadas com o abastecimento nacional de combustíveis, fiscalizando-as diretamente ou mediante convênios com órgãos da União, dos Estados, do Distrito Federal e dos municípios.

Em relação à fiscalização, a reeditada Medida Provisória MP №1.883-16, de agosto de 1999, dispõe sobre a fiscalização das atividades relativas ao abastecimento nacional de combustíveis (de que trata a Lei № 9.478/97), e estabelece as sanções administrativas para a comercialização do álcool combustivel fora do contexto do governo.

As alterações promovidas nesta reedição da medida provisória não tiram a necessidade de autorização para a comercialização do álcool combustível, que também é objeto da Portaria ANP No 29, de fevereiro de 1999. Conforme esta Portaria, que estabelece as regras para a distribuição do setor de combustíveis, a compra dos combustíveis terá que ser feita somente de fornecedores autorizados e observar os volumes mensais referendados pela ANP ou órgão responsável pela política de comercialização do álcool combustível.

\subsubsection{As diferenças regionais}

Uma questão bastante importante relativa à necessidade da interferência governamental no setor são as diferenças estruturais de competitividade, que se evidenciam tanto pelas diferenças de custos agrícolas entre as regiões produtoras, como 
pela logística de distribuição do álcool combustível nos centros de consumo. Estas diferenças estruturais de competitividade causam muitas discussões no setor, já que existe apoio do governo (tanto para a produção de cana-de-açúcar como para o frete) às atividades nas regiões menos competitivas.

\subsubsection{O suporte à cana-de-açúcar}

Inicia-se pelo suporte econômico que é dado à produção de cana-de-açúcar para fabricação de álcool ${ }^{126}$, de forma a cobrir os custos adicionais de algumas regiões, devido à diferença de produtividade agrícola (que na safra de 1998/99 foi de 81,6 toneladas de cana por hectare na região Centro-Sul e 62,2 toneladas de cana por hectare na região Norte-Nordeste).

Conforme visto anteriormente, o suporte dado à cana-de-açúcar do Nordeste existe desde 1971, com o objetivo de equalizar os custos de produção entre as duas regiões. Esperava-se que ele fosse vigorar por um período de 7 anos, prazo no qual as novas variedades de cana a serem desenvolvidas no PLANALSUCAR, juntamente com a modernização do parque sucroalcooleiro nacional, seriam suficientes para que o apoio governamental não fosse mais necessário.

Porém, a realidade mostrou que, apesar dos ótimos resultados obtidos com o Programa de Modernização do Parque Nacional e com o desenvolvimento de novas variedades, não foi possível cumprir o ambicioso plano do governo de eliminar o suporte à cana-de-açúcar da região Nordestina, sendo que os mesmos, além de existirem até hoje, foram estendidos a outros Estados, conforme a Resolução do CIMA №10, de fevereiro de 1999.

A opinião do governo em relação ao suporte agrícola à cana-de-açúcar destinada a produção de álcool no Nordeste é que ele deve ser mantido de forma a assegurar a produção naquela região, já que não é considerada viável a erradicação da cana-de-açúcar do Nordeste.

\footnotetext{
${ }^{126}$ Atualmente a cana-de-açúcar destinada à produção da açúcar não é suportada pelo governo. Conforme a Resolução № 10 do CIMA, fazem jus ao suporte os Estados da Região Norte e Nordeste, e alguns do Centro-Sul: Mato Grosso, Mato Grosso do Sul, Minas Gerais, Rio de Janeiro, Espírito Santo e Goiás.
} 
Até o momento consideram que não houve justificativa convincente para substituir a produção de energia na região Nordeste (uma energia renovável, limpa, que está sendo procurada pelo resto do mundo) por outra cultura. Primeiramente porque não existe uma cultura que possa substituir a cana naquela região em escala adequada ${ }^{127}$, e também porque a atividade canavieira do Nordeste é competitiva quando comparada com o resto do mundo, ela não é quando comparada com a região Centro-Sul. ${ }^{128}$

Além disso, considera que é uma questão de política de governo, que precisa ter uma alternativa para determinada região, de forma a garantir o nível de emprego.

Em relação aos outros grupos de entrevistados, notou-se que não houve consenso em relação a esta questão. $\mathrm{Na}$ categoria dos fornecedores, um entrevistado sustenta que sem a existência do suporte agrícola para a região Norte-Nordeste, em ambiente de livre mercado, não é possível a sobrevivência dos fornecedores devido à diferença de produtividade decorrente das condições edafoclimáticas.

Salienta que a cana-de-açúcar é a única fonte de emprego da região, que não existe outra cultura para substituir a extensão plantada de cana, e que a mão-de-obra dos canaviais dificilmente conseguirá ser alocada em outra atividade.

Por outro lado, as Associações de Fornecedores de outras regiões mais produtivas, embora reconheçam as dificuldades existentes naquela região, ressaltam que o nível de suporte dado aos produtores do Norte-Nordeste ( $\$ 5,07$ reais por tonelada) representou, na șafra 98/99, mais de $30 \%$ do preço da cana estabelecido para a região Centro-Sul.

$\mathrm{Na}$ categoria dos industriais, as opiniões foram divergentes e bastante explícitas. Houve um grupo (que inclui produtor do Centro-Sul), que considerou que, dadas as diferenças de competitividade existentes na região Norte-Nordeste (que tornam os custos de produção mais altos naquela região), e, considerando as questões sociais envolvidas

\footnotetext{
127 O clima da Região faz com que as frutas amadureçam numa velocidade extremamente rápida, dificultando sua comercialização; o volume de frutas a ser produzido nos canaviais dificilmente encontraria mercado consumidor.

${ }^{128}$ Conforme Serodio, o custo de produção de cana na região Norte-Nordeste é o $4^{\underline{Q}}$ menor do mundo. Os menores custos são: Brasil, Austrália, África do Sul e Nordeste, embora reconheça que a rendimento industrial da cana do Nordeste, em termos de álcool/tonelada de cana, seja menor.
} 
(emprego, renda per capita muito baixa, dificuldade de substituição da cultura, impossibilidade de mobilidade da mão-de-obra), o suporte deve ser mantido, mas somente sobre determinado tamanho, de forma a não incentivar expansões em regiões de produtividade menor.

Ainda nesta categoria, um entrevistado considerou que além do suporte ser somente sobre dado volume de cana, ele deve estar vinculado a aumentos comparativos contínuos de produtividade (dentro da mesma região), de forma que o suporte não seja usado como instrumento de estagnação da produtividade. ${ }^{129}$

Os industriais que se mostraram contrários ao suporte agrícola justificam que com o mercado cada vez mais competitivo, e dado que o preço da matéria prima impacta bastante o produto final, qualquer diferença que o governo faça para alguma região produtora pode ser decisiva.

Além disso, consideram que o suporte não se justifica porque as condições hoje são diferentes da década de 70 , já que o Nordeste tem vantagens na exportação do açúcar (localização geográfica, investimentos feitos em portos) que torna suas exportações mais competitivas que a dos demais Estados.

Outro entrevistado considera que näo deveria haver suporte para nenhum estado, e sim uma proteção equivalente ao frete entre as duas regiões, de forma a proteger a região Nordeste contra a entrada do produto final do Centro-Sul, ou seja:

$$
\mathrm{P}_{\text {equivalente } \mathrm{NE}}=\mathrm{P}_{\text {equivalente } \mathrm{C} / \mathrm{S}}+\text { frete }
$$

Desta forma, o preço do produto final do Nordeste seria maior que o do CentroSul devido ao frete. Através do CONSECANA, este diferencial de preços seria repassado ao preço da tonelada de cana do Nordeste, que seria maior que o preço na região Centro-Sul.

\footnotetext{
${ }^{129}$ Conforme o entrevistado, nos últimos 15 anos, mesmo com as intempéries climáticas existentes na região Nordeste, os aumentos de produtividade foram de $4,5 \%$ a $5 \%$ ao ano; sendo que é a região de maior área de cana irrigada do Brasil.
} 
Conforme Pindyck \& Rubinfeld ${ }^{130}$, ao se analisar uma política de suporte de preços que desloca o excedente de um grupo para outro, deve-se levar em conta que mesmo que se considere o bem estar dos consumidores e produtores igualmente, ela geralmente resulta em perda líquida ${ }^{131}$ de bem estar pela sociedade. A perda é uma forma de ineficiência econômica que deve ser considerada quando as políticas são elaboradas e implementadas.

A política de suporte de preços implica num custo para o governo (que será pago através dos impostos ${ }^{132}$, acarretando um custo para toda a sociedade) sendo que é relevante identificar os ganhos de bem-estar da sociedade como um todo. Por outro lado, o governo e a sociedade que ele representa podem ter outros objetivos além dos econômicos, que justifiquem a adoção da tais políticas.

Segundo Pindyck \& Rubinfeld (1994, p.390), quando se pretende garantir uma renda adicional de dado segmento, o menos dispendioso para a sociedade, é que este receba o pagamento de forma direta, ao invés de política de suporte de preços (que implica em perdas líquidas). Porém, a simples doação de um recurso pelo governo nem sempre é a opção escolhida, embora seja a economicamente mais eficiente, porque politicamente não é a opção mais atraente.

Desta forma, considerando que não existe a intenção de se erradicar a cultura da cana-de-açúcar das regiões menos competitivas, a forma escolhida pelo governo para melhorar a renda dos fornecedores de certas regiões, que é dar um complemento em dinheiro ao valor praticado no mercado, implica em perdas menores de bem estar para a sociedade quando comparada com uma política de suporte de preços.

Por outro lado, é interessante notar que os subsídios regionais destinados aos produtores de cana-de-açúcar da região Norte-Nordeste, existentes desde 1971 (que nesta

\footnotetext{
${ }^{130}$ Os autores tratam das perdas de bem-estar decorrentes das diversas políticas governamentais: política de preços mínimos, de suporte de preços e quotas de produção, de quotas de importação e impostos de importação, dentre outras.

${ }^{131}$ Ao se analisar as variaçōes ocorridas nos excedentes do consumidor e do produtor decorrentes da política, nota-se uma perda líquida de excedente (que não é apropriado por ninguém), chamada na literatura microeconômica de deadweight loss.

${ }^{132}$ Os recursos gastos pelo governo com os suportes feitos ao setor sucroalcooleiro não são pagos com o dinheiro arrecadado via impostos, e sim de um sobre-preço cobrado da gasolina (conta PPE).
} 
data eram previstos para durar por sete anos), não só existem até hoje, como foram ampliados (pela Resolução do CIMA №10, de fevereiro de 1999) para os Estados de Mato Grosso, Mato Grosso do Sul, Minas Gerais, Espírito Santo, Goiás, Pará, Rio de Janeiro e Tocantins.

\subsubsection{O Suporte ao frete}

O suporte econômico atualmente dado pelo governo aos produtores de álcool de Mato Grosso e Mato Grosso do Sul, conforme a Resolução №10 do CIMA, de fevereiro de 1999, é válido por um prazo de cinco anos, sendo que seu valor começa a decrescer a partir do segundo ano. O objetivo deste suporte é que os produtores destas regiōes possam competir no mercado interno, em ambiente de livre mercado, dado que a maioria se encontra distante dos centros consumidores e dos centros de mistura das refinarias, e necessita de um tempo para abrir mercado para seus produtos, já que até então o acesso a determinados mercados regionais era negado pelo próprio governo. ${ }^{133}$

As empresas mais afastadas das bases de distribuição e dos grandes centros consumidores (como por exemplo as 21 usinas e destilarias da região de Araçatuba, criadas a partir de 1978, com o início do Proálcool e sob forte estímulo governamental), sentem-se em desvantagem em relação àquelas mais bem localizadas, alegando que, apesar de investirem com sucesso na indústria, lavoura e em projetos de transporte para reduzir os custos, a distância de $500 \mathrm{~km}$ até a base de Paulínia as impede de concorrer com as demais. ${ }^{134}$

A opinião da representante do governo entrevistada em relação a estas unidades localizadas distantes dos centros de consumo é que na época do Proálcool elas atenderam a um chamado do governo, que por questões políticas (expansão da fronteira agrícola, distribuição de renda) estimulou sua implantação nestas regiões mais distantes,

\footnotetext{
${ }^{133}$ Por exemplo, na mesa de comercialização o álcool do Mato Grosso não podia ser vendido para o mercado da região Norte. Embora agora possa, existe um tempo até que as empresas conquistem novos mercados.

${ }^{134}$ Segundo o artigo "Governo retoma o Proálcool". Gazeta Mercantil, p. A-6, 17/08/1998.
} 
garantindo que as respectivas produções seriam trazidas até as fontes de mistura (Paulínia) ou às centrais de distribuição.

Conforme a entrevistada, embora estas unidades apresentem produtividades altas, elas têm um custo adicional de transporte para trazer sua produção até os centros de consumo. Como as unidades destas regiões ainda não conquistaram os mercados regionais (situação que se agrava dados os excedentes atuais de produção), elas precisarão de um apoio governamental - temporário e decrescente - de forma a se organizarem, seja pela conquista de novos mercados, ou pela redução de custos pela utilização de novos modais de transporte (incluindo o hidroviário), para que os investimentos feitos em infra-estrutura (as fábricas, a tancagem existente), e os empregos gerados não sejam perdidos.

Outra categoria que se posicionou sobre o suporte ao frete foi a dos industriais: uma parte é radicalmente contra; a maioria acha que passados os cinco anos, este suporte pode ser retirado porque neste período as empresas já estariam em condições de competir em livre mercado; alguns acham que ele é necessário para garantir a sobrevivência daquelas unidades; e outra acha que embora ele não seja mais necessário passados os cinco anos, questões políticas não permitirão que ele seja retirado.

Começando pela última, sua opinião é que houve uma falha de planejamento por parte do governo ao estimular a localização destas destilarias nestas regiões, e que agora por questões políticas ele não tem como sair. Além desta, considera outra falha ter permitido que houvesse uma expansão de forma descontrolada, sem planejamento, naquelas regiões. Acredita também que o governo não vai deixar que a produção de combustível fique toda concentrada numa só região, e dadas as diferenças estruturais, não acredita na retirada do suporte, que vai depender do quanto a indústria representa em termos econômicos no Estado.

Os que são contra a existência do suporte alegam que muitos incentivos foram dados pelo governo no início do Proálcool, tais como: criação de reserva de mercado para o álcool anidro (atrelado ao consumo do petróleo); financiamento de máquinas, equipamentos, e da parte agrícola a juros particularmente interessantes, e que passados 
20 anos os investimentos feitos pelo setor já teriam sido amortizados. Desta forma, qualquer responsabilidade que o governo pudesse ter com estas empresas já teria terminado.

Alegam também que o risco do empresário é o mercado, e que se o governo continuar com as medidas de apoio aos menos competitivos, o setor sempre estará contaminado com a super-oferta, com problemas de inadimplência, o que acaba prejudicando os mais eficientes. Portanto, acreditam que estas empresas competem de forma muito diferenciada em relação as que estão próximas dos centro de consumo, e que se não são viáveis sem o suporte do governo devem sair do mercado.

Por sua vez, alguns representantes dos industriais acreditam que o suporte ao frete é fundamental para garantir a competitividade daquelas unidades em ambiente de livre mercado. Salientam, por exemplo, que o Mato Grosso produz mais de uma vez o consumo regional, que precisa de um mecanismo para conseguir escoar sua produção, dentro de uma matriz energética equilibrada. Que não existem condições, em livre mercado, de competirem com as usinas localizadas junto aos centros de consumo.

Por outro lado, alguns acham que, embora não se possa perder o parque industrial já instalado, o número de empregos e o desenvolvimento industrial gerados pelo setor, o montante dos recursos não deve ser ampliado. Deve ser definido o tamanho do suporte, respeitando as características regionais, problemas de produtividade, de frete, problemas sociais, sem estimular o crescimento nestas regiões, que deve ser definido de forma gradual e planejado, nas regiões de custos mais baixos.

Finalmente, existe um grupo, dentro ainda da categoria dos industriais, que acredita que passados os cinco anos o suporte ao frete não será mais necessário (ou não pode mais existir), porque após este tempo, muitos dos problemas hoje enfrentados por aqueles produtores terão diminuido.

Primeiramente em relação ao transporte, diversas alternativas ao rodoviário estão se apresentando de forma a reduzir os custos e permitir o acesso a novos mercados, inserindo o Mato Grosso e o restante do Centro-Oeste no processo de desenvolvimento do País. Dentre elas destacam-se: o transporte fluvial pela hidrovia Madeira-Amazonas 
(com embarque em Porto Velho) vai estar funcionando; o acesso ao mercado da Região Norte (Rondônia, Acre, Pará, Amazonas) terá transporte adequado; e a ferrovia Ferronorte permitirá abastecer o mercado externo via Porto de Santarém.

Dentro deste grupo, alguns consideram que o frete tem um peso pequeno na composição do preço final, sendo que ele pode até ser compensado pelo menor custo da matéria-prima naquelas regiões mais distantes (que normalmente tem preços de arrendamentos de terra menores). Salientam que as distribuidoras compram o produto o ano todo, de forma coordenada (ou seja, não vão comprar todo o estoque de uma região para depois comprar de outra), estando mais preocupadas com condições de abastecimento do que somente de preços.

Porém, salientam que é necessário que cada um adequie a quantidade produzida e o perfil de sua produção (álcool hidratado, anidro ou açúcar) conforme as necessidades dos mercados regionais, ou daqueles centros de consumo a que tem acesso de forma competitiva, sem o suporte do governo.

\subsection{Determinantes políticos dos processos decisórios: os atores e seus recursos de} poder e a redefinição de seus papéis no novo ambiente institucional

A crise fiscal do Estado brasileiro e seu conseqüente afastamento da economia do país a partir da década de 1990, associada a passagem de um regime com fortes traços autoritários e burocráticos para um democrático, e o fortalecimento do Congresso a partir da promulgação da Constituição Federal de 1988, evidenciaram uma mudança importante do papel dos atores e seus recursos de poder envolvidos nos determinantes das políticas públicas.

Especificamente em relação ao setor sucroalcooleiro, a alteração do ambiente institucional trouxe a necessidade de articulação e coordenação entre os agentes da cadeia, significando uma drástica mudança dos papéis até então vividos, já que anteriormente o Estado assumia não só as funções de planejamento e comercialização dos produtos do setor, como também era o mediador dos conflitos que sempre permearam sua história. 
A mudança institucional além de aiterar os papéis dos atores tradicionais e as arenas decisórias (dado o fortalecimento do Congresso), fez com que atores até então secundários assumissem posição de destaque nos processos decisórios (caso dos pequenos produtores de cana e dos trabalhadores).

Esta seção é dividida em duas partes. A primeira objetiva identificar os atores envolvidos no processo de desregulamentação. Na segunda, procura-se determinar os atores e recursos de poder no novo ambiente institucional, e comparar a estrutura decisória atual com a da época da criação do Proálcool.

\subsubsection{O processo de desregulamentação e os atores envolvidos}

Os quatro adiamentos da liberação do setor sucroalcooleiro (que a princípio ocorreria em janeiro de 1997, mas que aconteceu totalmente somente dois anos após, em fevereiro de 1999), evidenciaram o conflito de interesses e opiniões existentes, e a necessidade de identificar os atores envolvidos para melhor entendimento do processo de desregulamentação.

Segundo Lamounier (1994), três elementos devem ser considerados para a análise dos determinantes das políticas públicas: as arenas decisórias, o contexto institucional, e o perfil dos atores relevantes.

Das três categorias de políticas públicas relacionadas pelo autor (de distribuição, de regulação e redistribuição), a que se adapta ao processo de desregulamentação do setor sucroalcooleiro é a política de regulação, já que os atores do setor deparam-se com recursos limitados, implicando em distribuição de custos e oportunidades para indivíduos e grupos.

Conforme Lamounier (1994), nas políticas regulatórias a arena decisória tem a característica de um "paralelogramo de pressões", sendo que as políticas públicas adotadas são vistas como a resultante das diversas forças envolvidas.

Desta forma, a identificação das arenas decisórias, dos objetivos e recursos de poder de cada um dos atores, e do contexto institucional são essenciais para a análise do processo e dos adiamentos da desregulamentação. 
Diversas considerações foram feitas nas entrevistas no que se refere aos grupos de interesse e seus objetivos. Identificam-se, primeiramente, dois grupos cujos problemas e interesses são distintos: as duas regiões produtoras, Norte/Nordeste e Centro-Sul.

A diferença de competitividade na área agrícola entre as duas regiões produtoras faz com que a região Norte-Nordeste necessite de subsídios para poder competir com a região Centro-Sul (o que não impediu que aquela região venha diminuindo sua produção nos últimos dez anos, em oposição ao crescimento da produção da região Centro-Sul).

A desregulamentação do mercado e as incertezas sobre a continuidade dos mecanismos de sustentação existentes encontraram resistência não só dos industrias da região Norte-Nordeste, como principalmente dos fornecedores de cana-de-açúcar, que lutaram pela prorrogação do tabelamento de preços deste produto, pela manutenção dos subsídios agrícolas, e pela regulamentação do governo no que se refere à sua comercialização.

Além disso, foi citado também que a região Norte-Nordeste tinha interesse em manter a intervenção (a utilização do sistema de cotas de produção nesta região é facilitada pelo fato da demanda ser maior que a oferta, contrariamente ao que ocorre na região Centro-Sul), como forma de controlar a expansão da produção da região CentroSul.

Na região Centro-Sul, também são identificados vários grupos de interesse, já que não havia unanimidade sobre os benefícios que a desregulamentação traria ao setor. Coexistiam grupos de produtores, técnicos do setor e algumas lideranças totalmente a favor da liberação, com outros que gostariam da volta da centralização anteriormente existente, e com aqueles que achavam que a liberação deveria ser feita mediante algumas regras impostas pelo governo.

As divergências de opiniões na região Centro-Sul advém de vários fatores. Primeiramente distinguem-se os estados desta região que objetivavam expandir sua produção. Para estes, era interessante manter a regulamentação e o sistema de cotas de 
produçăo, de forma a evitar que os estados mais competitivos impedisse seu crescimento.

Além disso, dentro desta região, os diferentes estados competem de forma diferenciada em relação ao custo do transporte do álcool combustível. Os produtores dos Estados mais distantes dos centros de consumo (Mato Grosso, Mato Grosso do Sul, Goiás, e produtores do oeste de São Paulo) teriam dificuldades de concorrer com os paulistas em ambiente de livre mercado, se a liberação ocorresse sem uma fase de transição, com certas regras estabelecidas. Desta forma, estes pressionavam para que a liberação ocorresse em outros termos, o que também contribuiu para o atraso da mesma.

Ainda na região Centro-Sul, no Estado de São Paulo, que é o maior estado produtor de cana-de-açúcar e dos produtos derivados, o setor também estava dividido: havia grupos que temiam a desregulamentação e outros que a almejavam (como a COPERSUCAR, que se sentia prejudicada com as distorções que aconteciam no sistema de cotas da mesa de comercialização de álcool do governo), confiantes que o livre mercado resolveria os problemas existentes, e que os mais competitivos estariam aptos para operar no regime liberado.

No meio destas discussões, foi criada, conforme visto anteriormente, uma nova associação de produtores de São Paulo, a UNICA, em substituição a tradicional entidade representativa (AIAA), com o objetivo de unificar os produtores frente as dificuldades emergentes da liberação, e fortalecer sua representação para lidar com o processo de desregulamentação e com o novo ambiente liberado.

Segundo alguns entrevistados, embora houvesse o apelo da união, as opiniões da UNICA sobre a desregulamentação eram conflitantes com os interesses de várias unidades produtoras, não só de outros estados que não faziam parte da entidade, como de algumas associadas também.

Além disso, os problemas enfrentados no setor durante o processo de desregulamentação (como os altos estoques de passagem na safra 1998/99, avaliados em 2 bilhões de litros, que pressionavam os preços dos produtos, aliado às projeções da 
nova safra, cujo volume estimava-se ser alto) dificultavam a convergência de opiniões sobre a questão da liberação.

Dadas as divergências de opiniões existentes, diversas unidades de São Paulo se afastaram da UNICA e, juntamente com produtores de outros estados associados à SOPRAL (que era a entidade representativa das unidades produtoras da geração Proálcool, que contava com produtores de SP, PR, MT, MS, GO e ES), criaram a CEPAAL (conforme visto anteriormente), que objetivava consolidar os interesses dos diversos estados produtores, de modo a conciliar as opiniões, e lidar com o novo ambiente institucional.

Conforme os entrevistados, outro fato que inicialmente dividiu o setor, e que também foi um dos motivos da criação da CEPAAL, foi a diferença de objetivos de longo prazo no que se refere a questão do álcool anidro versus hidratado (embora esta questão tenha se enfraquecido ao longo do tempo dados os altos estoques existentes na safra 1998/99 e a necessidade de reativar o Proálcool).

Alguns produtores afiliados à UNICA acreditavam que, dado o enxugamento do Proálcool, e a queda de demanda pelo álcool hidratado, os esforços do setor deveriam ser feitos para incentivar a produção e o uso do álcool anidro, usado como aditivo à gasolina. Dentre as razões citadas, estão: para o álcool anidro já existe uma reserva de mercado (assegurada por lei), que garante uma demanda proporcional ao teor da mistura $(24 \%)$; que tem maior viabilidade econômica em relação ao hidratado porque seu poder energético é maior, substituindo a gasolina na razão de 1 para 1 , podendo competir com este produto em livre mercado; está em sintonia com o mercado global, que procura um oxigenante não poluente para ser adicionado à gasolina (para substituir o chumbo tetra etila), o que facilita sua aceitação por parte dos vários agentes (incluindo as montadoras, que dispõe de fontes mundiais de motores para alguns veículos, e os produtores de gasolina).

Porém, o estímulo ao álcool anidro, sem aumentar a demanda pelo hidratado, pressupunha um encolhimento do programa do álcool, com consequiente redução das unidades produtivas. 
Por sua vez, as destilarias oriundas da fase do Proálcool, que foram montadas para produzir o hidratado, enxergavam que este deveria ser o principal produto, devendo o álcool anidro funcionar como um regulador dos estoques, já que ele pode ser adicionado à gasolina em proporções variáveis (no caso de falta de produto, seu teor na mistura poderia ser reduzido, e na situação inversa, poderia ser aumentado).

Embora esta questão também tenha dividido o setor, a grave crise de super produção enfrentada na safra 1998/99 diminuiu sua a importância relativa, já que os agentes se uniram em torno da necessidade de aumento da demanda pelos dois produtos (anidro e hidratado).

Portanto, para tratar da questão da desregulamentação, passaram a existir, na região Centro-Sul, duas entidades representativas dos industriais, cada uma com sua visão sobre o processo: enquanto a UNICA se mostrava a favor do livre mercado, com regras mínimas para a fase de transição e para o futuro, a CEPAAL acreditava que a liberação deveria ser postergada, devido ao grande estoque existente na safra 1998/99, e à falta de regras de transição, necessárias para permitir a convivência dos estados produtores com desvantagens competitivas (decorrentes dos problemas de logística). Além disso, a CEPAAL acreditava ser necessário uma regulamentação para formalizar a comercialização do álcool para as distribuidoras de combustíveis, impondo a contratação formal de certa quantidade de álcool demandada pelo mercado.

A partir de então, nas arenas decisórias, os seguintes atores principais pressionavam e mobilizavam seus recursos para atingir os objetivos almejados: as duas entidades representativas dos produtores do Centro-Sul, as dos produtores do NorteNordeste, e os representantes dos fornecedores de cana-de-açúcar (incluindo os da região Norte-Nordeste, que têm um apelo social muito grande, dado o grande número de pequenos fornecedores existente, e se opunham à liberação do preço da cana-de-açúcar.

Em relação à estrutura decisória, conforme visto anteriormente, em agosto de 1997 foi criado o CIMA, visando mudar o sistema descentralizado de tomadas de decisões, que requeria a coordenação dos diferentes órgãos do governo afetos ao produto 
(as características multidisciplinares do álcool fazem com que vários ministérios ${ }^{135}$ estejam envolvidos nas decisões sobre o setor), e com o objetivo de analisar e propor políticas relativas ao setor sucroalcooleiro.

Além do fato das decisões do CIMA terem força de decreto, a partir de sua criação o Ministro da Fazenda Pedro Malan (que emitiu todas as medidas provisórias referentes à desregulamentação) passou a considerar as opiniões do Conselho nas tomadas de decisões referentes ao setor. Isto fica claro ao se analisar os considerandos da Medida Provisória Nㅗ102 ${ }^{136}$ (que prorroga a liberação dos preços do setor de maio de 1998 para novembro de 1998), e que denota a influência do CIMA no processo de desregulamentação.

É importante notar que faziam parte do comitê consultivo do CMA seis representantes dos produtores de açúcar e álcool das duas regiões produtoras (de diferentes estados); quatro representantes dos fornecedores de cana; quatro parlamentares da Câmara dos Deputados de diversos partidos e regiões; e dois senadores da República (do Rio Grande do Norte e de Mato Grosso).

Portanto, dadas as divergências existentes anteriormente comentadas, e considerando-se que os diversos grupos envolvidos tinham acesso, através do Conselho Consultivo, ao CIMA (que era a arena decisória, não só pelas suas Resoluções, como também porque o CIMA era o órgão que assessorava o Ministro Pedro Malan nas políticas referentes ao setor), fica claro que os adiamentos ocorridos foram resultantes das pressões dos diversos grupos envolvidos, cada qual lutando por seus objetivos.

\footnotetext{
${ }^{135}$ Ministério da Agricultura, Fazenda, Minas e Energia, Ciência e Tecnologia, Orçamento, Transportes, Desenvolvimento, Meio-Ambiente, Relações Exteriores.

${ }^{136}$ Segundo a MP №102: “... considerando a necessidade de realização de amplo diagnóstico do setor sucroalcooleiro, contorme decidido pelo Conselho Interministerial do Açúcar e do Álcool (CIMA), com vistas a identificar e corrigir os desequilíbrios estruturais do setor; considerando a existência, no presente momento, de estoques de passagem de álcool carburante que poderão pressionar os níveis de preços do produto, podendo afetar a renda e o emprego do setor; considerando a necessidade de definir regras ou padrões de comercialização para o álcool carburante, previamente à liberação total do mercado; e considerando a necessidade de aprofundar as discussões sobre a comercialização da cana-de-açúcar em ambiente de liberdade de preços, resolve: ...".
} 


\subsubsection{O novo ambiente desregulamentado: os novos atores e seus recursos de poder}

Conforme salientado em Helfand (1994), a análise das escolhas das políticas governamentais deve considerar a interação de quatro fatores: o Estado, o regime político, a economia e os grupos de interesse.

Desta forma, ao se analisar o novo ambiente institucional vigente, notamos que o processo de redemocratização do país iniciado com Tancredo Neves a partir 1985 , associado à abertura da economia brasileira, à promulgação da Constituição Federal de 1988 e à crise fiscal do Estado, são alterações importantes a serem consideradas, com implicações sobre os atores e seus recursos de poder.

Especificamente em relação ao setor sucroalcooleiro, a redemocratização do País implicou numa grande mudança do ponto de vista político no que se refere ao Proálcool. Conforme analisado em Santos (1993), o Brasil autoritário pós-64 caracterizase pela simultaneidade entre a centralização do poder nas mãos do Executivo (especialmente do Presidente da República e seus assessores diretos) e pela fragmentação do aparelho do Estado, com a proliferação das agências burocráticas, cada uma ligada a um aspecto específico da política econômica.

$\mathrm{Na}$ fase de formulação e implantação do Proálcool, Santos $(1993)^{137}$ identifica os seguintes atores públicos: o presidente da República, Ernesto Geisel; os Ministérios da Indústria e Comércio, Minas e Energia, Fazenda, Agricultura; a Secretaria de Planejamento (SEPLAN): o Instituto do Açúcar e do Álcool (IAA); a Petrobrás e o Conselho Nacional de Petróleo (CNP); o Centro Técnico da Aeronáutica (CTA); a Secretaria de Tecnologia Industrial (STI); o Conselho de Desenvolvimento Econômico (CDE); a Comissão Nacional de Energia CNE; o Conselho Nacional do Álcool (CNAL); a Comissão Executiva Nacional do Álcool (CENAL); o Conselho de Desenvolvimento Industrial (CDI); o Conselho Monetário Nacional (CMN), o Banco Central e os agentes financeiros.

\footnotetext{
${ }^{137}$ Os atores aqui identificados não estão separados segundo as fases do Proálcool (elaboração e implantação) conforme feito em Santos (1993).
} 
Dentre os atores privados, Santos (1993) relaciona: a Cooperativa dos Produtores de Açúcar e Álcool do Estado de São Paulo (COPERSUCAR), o Sindicato da Indústria de Fabricação de Álcool no Estado de São Paulo (SIFAESP); a Cooperativa Fluminense dos Produtores de Açúcar e Álcool (COPERFLU); o Sindicato da Refinação de Açúcar dos Estados do Rio de Janeiro e Espírito Santo; associações de produtores e fornecedores de cana e a Associação Brasileira das Indústrias Químicas (ABIQUIM).

Com o regime autoritário então vigente, o papel do Legislativo foi reduzido ao mínimo e a função do Judiciário era quase cerimonial. Os pequenos plantadores de cana e os trabalhadores, embora profundamente afetados pelo programa, estavam fora do processo decisório.

Segundo a autora, a fragmentação da estrutura decisória na fase de implementação do Proálcool (que causou disputas entre agências, que frequientemente competiam entre si, dadas as superposições das competências), foi corrigida na segunda fase do Programa, quando o MIC emergiu como a organização hegemônica do centro de decisão.

A partir de então, embora cada agência burocrática fosse responsável por determinadas políticas, os vários centros de decisões (produção, distribuição e atividades financeiras) assumiram seus formatos definitivos, permitindo que os atores privados canalizassem suas demandas para pressionar por seus interesses. Os conflitos interburocráticos, ou entre os atores públicos e privados eram resolvidos pelo próprio Presidente da República.

Conforme a autora, influenciar o processo de tomada de decisão dependia da capacidade dos atores de ter acesso ao aparelho do Estado, que era a arena privilegiada de decisão, o que era restrito aos grupos de grandes proprietários afetados pelo programa, dentre eles: plantadores de cana, usineiros, proprietários de destilarias autônomas, fabricantes de destilarias, montadoras de automóveis e seus respectivos sindicatos e associações de interesse, além dos próprios governadores de estados do Nordeste, que atuavam em defesa dos interesses de seus estados. 
A importância relativa de cada um destes grupos dependia das circunstâncias conjunturais internas e externas e da fase do programa. É importante salientar que nesta época os trabalhadores e pequenos plantadores de cana eram excluídos da representação de interesses, e portanto, dos processos decisórios.

Com a redemocratização do País, passou a existir uma crítica muito forte ao Proálcool por partę dos agentes que não participaram do seu processo de criação. Mesmo havendo os que reconheciam que o programa tinha aspectos interessantes (do ponto de vista de geração de renda, de economia de divisas, do ponto de vista de poluição, de geração de empregos, descentralização da produção, etc.), a imagem formada pela sociedade sobre ele é extremamente negativa, não só pela forma ditatorial como foi criado (visto que o Presidente Ernesto Geisel e seus ministros resolveram e fizeram o programa), como também pelas constantes notícias veiculadas na mídia ao longo do tempo sobre as questões dos subsídios, do endividamento das usinas, de sonegação fiscal, de problemas trabalhistas (incluindo trabalho infantil), que acabaram por enfraquecer o programa.

Pelo lado econômico, a queda dos preços do petróleo tornou difícil a sustentação do Proálcool perante a opinião pública (o álcool depende de suporte oficial para competir com a gasolina), principalmente quando se considera a falência do Estado brasileiro, cujos recursos sequer são suficientes para assegurar educação e saúde à população.

Desta forma, alguns atores do setor sucroalcooleiro percebem que a retomada do Proálcool (almejada devido os excedentes de cana-de-açúcar existente, que conforme visto anteriormente apresentou um crescimento muito maior que o necessário para atender a demanda dos produtos finais) em um ambiente democrático, associado a uma crise econômica (que reduz a quantidade de subsídios disponíveis), não poderia ser feito da mesma forma e através dos mesmos canais existentes na época de sua criação.

Portanto, a percepção destes agentes do setor de que as arenas decisórias haviam mudado alterou completamente o modo de pressionar pelos interesses. É interessante notar que a partir de então emergiram atores e arenas decisórias (por 
exemplo os trabalhadores e pequenos fornecedores de cana, e as manifestações públicas), que na época de criação do Proálcool não tiveram nenhuma influência nas escolhas das políticas, enquanto outros tiveram sua influência intensamente reduzida.

Primeiramente reconhece-se a dificuldade do Governo Federal em definir a política do álcool, e a necessidade de se levar a discussão para o Congresso Nacional, que até então tinha poucas informações sobre a questão da inserção do álcool na matriz energética nacional.

Verificado o papel fundamental da ação política ${ }^{138}$ para manter o assunto na pauta da discussão do Congresso, surgiu a necessidade de um trabalho conjunto dos produtores com a base parlamentar.

Desta forma, a partir da ação dos sindicatos de produtores de São Paulo (SIAESP/SIFAESP), foi criada, em 1996, a Frente Parlamentar do Setor Sucroalcooleiro, e que representa a defesa dos interesses dos Estados produtores no Congresso, sendo inicialmentecomposta por deputados federais dos estados de São Paulo, Alagoas e Pernambuco. A Frente Parlamentar é uma coligação supra-partidária, atualmente formada por parlamentares dos estados sucroalcooleiros de todo o Brasil (NE, PR, SP, MT, GO, MG, RJ).

Por sua vez, os Governos dos Estados e os prefeitos, que na fase anterior não tiveram papéis relevantes, emergem como importantes agentes de pressão, na medida em que reconhecem a importância da agroindústria açucareira como fonte de receita e de empregos para seus estados e municípios.

Conforme um dos entrevistados, as células do movimento democrático são as cidades. Nos municípios é onde se vive, se planta a cana, se produz, se geram os empregos e se recolhem os impostos. Se a produção gera benefícios para a cidade, interessa à população, aos trabalhadores e ao prefeito estimular sua produção. Portanto,

\footnotetext{
${ }^{138}$ Dentre os vários instrumentos disponiveis aos parlamentares para pressionar os agentes envolvidos nas determinações das políticas públicas estão as audiências públicas, que podem ser convocadas pelas diversas comissões existentes (de economia, de trabalho, de justiça, etc.), nas quais os convocados são obrigados a comparecer para prestar os esclarecimentos solicitados.
} 
eles são importantes agentes de pressão sobre o governador, junto com aqueles que representam o povo nas suas Câmaras Legislativas.

Por sua vez os governadores daqueles estados produtores cuja participação da agroindústria canavieira tiver relevância econômica, com seus Secretários de Estado, sua base de deputados, assembléia e prefeitos são a segunda fase do processo, sendo importantes para pressionar o Governo Federal em torno dos interesses de seus estados, e para criar estímulos ao setor como forma de preservar a atividade.

E o Governo Federal, que teve o principal papel na elaboração e implantação do Proálcool, no novo ambiente institucional tem seu poder reduzido.

Embora esta linha de raciocínio não seja unânime no setor (como será exposto a seguir, muitos acreditam que o Governo Federal ainda é o principal ator), a evolução dos acontecimentos no ano de 1999, principalmente no Estado de São Paulo, denotam o grande esforço dos agentes em sensibilizar as populações dos municípios canavieiros, e em mobilizar os trabalhadores, produtores, e prefeitos para atuarem como agentes de pressão junto aos governos do Estados.

Conforme visto anteriormente, em 1999 ocorreram várias manifestações nos municípios canavieiros para protestar contra a falta de apoio ao setor, e para reivindicar estímulos estaduais e federais: o "Pró-Cana", na cidade de Piracicaba (SP); manifestações em Araraquara (SP); fechamento de quatro rodovias da Alta Paulista; o "Grito contra o Desemprego e pela Produção" em Ribeirão Preto (SP); distribuição de 20.000 litros de álcool das destilarias da Alta Noroeste em Araçatuba (SP); e protestos nas cidades de Jaú (SP) e Valparaíso (SP).

As manifestações acabaram por sensibilizar o Governador Mário Covas, que solicitou uma audiência com o Presidente da República para discutir os problemas da agroindústria sucroalcooleira.

A seguir, houve o ato de Brasília denominado "Dia Nacional de Luta pelo Emprego", que reuniu produtores de cana-de-açúcar, de açúcar, de álcool, trabalhadores, sindicalistas, autoridades e parlamentares de todo o País, e que foi realizado 
simultaneamente em vários municípios canavieiros (Capivari, Catanduva, Jaú, Lençóis Paulista, Piracicaba e Sertãozinho).

Todas estas manifestações culminaram com a assinatura, no Estado de São Paulo, do "Pacto pelo Emprego no Negócio Sucroalcooleiro", em agosto de 1999. O governador de São Paulo Mário Covas assinou o referido pacto, envolvendo além do próprio Governo do Estado de São Paulo, o Governo Federal, governos de diversos municípios canavieiros, a indústria automobilística, a indústria de açúcar e álcool, os trabalhadores ligados ao setor, e as distribuidoras de combustíveis.

É importante notar a relevância dos papéis assumidos por atores que na criação do Proálcool não tinham sequer representação junto às agências federais responsáveis pelo programa: os trabalhadores do setor. Isto fica claro não só nas manifestações públicas, como também quando se verifica que três presidentes de Federações de Trabalhadores (Indústrias Químicas e Farmacêuticas do Estado de São Paulo, Indústrias de Alimentação e Afins do Estado de São Paulo, Agricultura do Estado de São Paulo) assinam também o "Pacto pelo Emprego no Negócio Sucroalcooleiro".

Dos 16 representantes dos industriais que se posicionaram sobre os principais atores no novo ambiente institucional, $44 \%$ acham que o Governo Estadual é o principal agente responsável pelo desenvolvimento do setor. Eles salientaram que os governos estaduais são mais sensíveis aos problemas sociais e econômicos, porque as questões de desemprego (industrial e rural), migração para os centros urbanos, geração de renda, poluição, afetam diretamente seus estados.

As principais ações estaduais requeridas pelos entrevistados foram estímulos para aumento da demanda pelo álcool combustível (isenção de IPVA para os carros a álcool, redução do ICMS do álcool (cuja alíquota é de 25\%) para possibilitar competição com gasolina; e adoção do carro a álcool nas frotas oficiais).

Um dos entrevistados salientou que o consumidor reage muito intensamente às diferenças de preço entre álcool e gasolina (migrando para um ou outro conforme os preços relativos dos combustíveis), e que os governos estaduais têm um papel importante sobre o controle das vendas de carros a álcool. 
O controle seria feito primeiramente mantendo um nível de paridade de preços na bomba que torne indiferente para o consumidor usar o álcool ou a gasolina, através da alíquota diferenciada de ICMS sobre os combustíveis. Depois, os governos estaduais atuariam com o ICMS na aquisição dos veículos, de forma a incentivar certos segmentos da frota, tais como as frotas estaduais, os táxis e as locadoras, que teriam alíquotas reduzidas.

Desta forma, as vendas de veículos a álcool seriam direcionadas para estes segmentos, que têm um impacto de $15 \%$ sobre as vendas totais, que é um volume possível de ser administrado pela indústria automobilística, e que representa uma escala de produção razoável para que ela tenha interesse na sua produção.

Conforme este grupo, ao Governo Federal caberia desenvolver novos mercados para os produtos da cadeia, através da redução das barreiras e tarifas a eles impostas, e algumas ações para incentivo da demanda (álcool no diesel, frota oficial a álcool, aumento do teor da mistura de $24 \%$ para $26 \%$, imposto seletivo, etc.), apesar de alguns reconhecerem as limitações das ações federais de incentivo ao produto num ambiente democrático.

Para estes entrevistados, a redução da intervenção do Estado na cadeia sucroalcooleira é substituída por um modelo de auto-gestão privada, na qual os Governo Estadual e Federal assumem o papel de monitoramento e de efetivação de determinadas políticas públicas. ${ }^{139}$

Os que consideram que as principais ações ainda cabem ao Governo Federal representam $25 \%$ dos entrevistados. Eles salientam que o Proálcool é um programa nacional, cabendo ao Governo Federal a responsabilidade sobre as questões de abastecimento. Um entrevistado acredita que a recuperação dos preços do açúcar e do álcool só será possível se o programa tiver os valores do passado, o que requer um planejamento federal para estabelecer os níveis mínimos e máximos de produção que a sociedade está disposta a acolher, já que existem recursos públicos envolvidos.

\footnotetext{
$139 \mathrm{Na}$ época da realização das entrevistas ainda não tinha sido assinado o "Pacto pelo emprego no agronegócio sucroalcooleiro", razão pela qual não há opiniões dos entrevistados sobre ele.
} 
As questões das diferenças regionais (fretes, produtividade agrícola), da comercialização da cana-de-açúcar, da necessidade de planejamento da produção, e de criação da demanda foram fatores citados para justificar a necessidade da intervenção Federal. Para este grupo, os governos estaduais têm papel secundário, cabendo a eles incentivar o álcool dentro do programa nacional.

Por sua vez, $31 \%$ dos industriais acreditam que tanto o Governo Federal como o Estadual ainda têm papéis importantes a desempenhar, já que deve haver uma somatória de esforços no sentido de estimular o uso do álcool combustível. Estes dois últimos grupos, da mesma forma que o primeiro, acreditam que o Governo Federal tem um papel importante no que se refere ao comércio internacional (lutar pela queda de barreiras e tarifas existentes para álcool e açúcar).

É interessante notar a divergência de opiniões no que se refere aos principais atores e arenas decisórias. Esperava-se que os agentes tivessem reconhecido o enfraquecimento do Governo Federal, e as limitações de seus recursos de poder, impostas pelo novo ambiente institucional (legal, político e econômico).

Porém, alguns atores ainda esperam que o Governo Federal atue nos moldes anteriores, e fazem severas críticas ao "abandono" atual que passa o setor. Provavelmente isto decorre do fato desses agentes terem vivenciado a fase de elaboração e implantação do Proálcool, e terem tido acesso aos canais centralizados dos processos decisórios (nos quais as decisões eram resolvidas entre poucos atores, sem envolvimento da sociedade, e de forma mais rápida), e tenham dificuldade em se adaptar ao novo ambiente institucional, no qual as decisões dependem de negociação entre os diversos agentes envolvidos.

Helfand (1994) e Lamounier (1994) analisam a mudança das arenas decisórias, dos atores e dos recursos de poder envolvidos nos processos decisórios de políticas agrícolas no Brasil a partir da redemocratização do país.

O primeiro autor salienta que para ter influência sobre as políticas públicas durante o período militar, era essencial que os agentes tivessem acesso aos altos escalōes do governo, dada a centralização das tomadas de decisão no Executivo, e que as ligações 
pessoais cornavam-se mais importantes do que as organizações, o que acabava favorecendo atores da elite excluindo a maioria.

Porém, segundo o autor, o processo de democratização no Brasil, associado à crise do Estado, levou a uma alteração dos principais atores e arenas decisórias envolvidas nas determinação de políticas agrícolas (que tornaram-se mais transparentes), e forçou o Estado e os grupos de interesse a procurar políticas alternativas, dada a inviabilidade da manutenção de créditos subsidiados.

No período 1964-84, conforme Helfand (1994), os principais atores, em ordem de importância, eram o Ministério da Economia, o Banco do Brasil, o Banco Central, e o Ministério da Agricultura, sendo que o Congresso e as Comissões de Agricultura tinham papel pouco relevante. Neste período, as principais arenas decisórias eram os altos escalões do governo e os contatos pessoais, sendo que o Congresso Nacional e as manifestações públicas tinham pequena importância relativa.

Já no período 1985-94, o autor identifica como principais atores o Ministério da Economia (que manteve sua posição praticamente inalterada), o Banco do Brasil e o Banco Central (que tiveram sua importância relativa reduzida), tendo aumentado o poder do Ministério da Agricultura e das Comissões de Agricultura do Congresso. Em relação às arenas decisórias, nota-se uma redução acentuada da importância dos escalões oficiais e dos contatos pessoais, e aumento significativo do Congresso e das demonstrações públicas.

Conforme o autor, com a nova Constituição, além do Congresso ter participação importante nas questões sobre o orçamento do Governo, e passar a exercer um papel relevante nas definições das políticas públicas, o fato dos congressistas votarem nas principais questões de interesse do Governo, implica que o Executivo deve ser mais receptivo aos congressistas e mais flexível ao negociar as políticas públicas, em troca de votos e suporte político. Como resultado, o Congresso passa a ser um canal importante através do qual os produtores podem pressionar os responsáveis pelas decisões no Executivo. 
Esta idéia é compartilhada por Lamounier (1994), que salienta que do ponto de vista dos processos de decisão na área agrícola, no período pós-Constituinte, embora o centro de gravidade continuasse localizado nos ministérios da área econômica (cuja prioridade era o combate à inflação), eles deixaram de ser um processo fechado e controlado pela burocracia estatal.

Conforme este autor, novos atores emergiram como consequiência da democratização e da crise fiscal do Estado, dentre eles o Congresso Nacional, os governadores de estado e seus secretários estaduais, as associaçõè̀ representativas dos produtores rurais (cujo poder é limitado pela heterogeneidade de interesses e dificuldade de mobilização), e o Ministério da Agricultura, que pode desempenhar um papel importante no processo decisório. Porém, em relação aos trabalhadores e pequenos produtores rurais, bem como consumidores, o autor acredita que continuam à parte dos processos decisórios.

Em relação ao setor sucroalcooleiro, é importante assinalar a importância crescente de outro ator público em ambiente de livre mercado, que é a Agência Nacional de Petróleo (ANP), na medida em que é o agente executor das políticas públicas referentes ao setor (determinadas pelo CIMA ou pelo Conselho Nacional de Política Energética), e que é o responsável pela manutenção dos estoques estratégicos do governo e pela fiscalização do setor de combustíveis.

As montadoras de veículos também têm um papel relevante (tal como tiveram na fase de criação do programa) no que se refere ao abastecimento do mercado de carros a álcool, e o seu envolvimento é fundamental para que as políticas de estímulo adotadas sejam efetivadas.

Por sua vez, os consumidores, embora não assumam papel importante no contexto de determinação de políticas públicas do setor sucroalcooleiro, exercem uma grande pressão sobre a demanda (já que são extremamente sensíveis aos preços relativos entre os dois combustíveis alternativos), o que acaba trazendo a necessidade de reformulação das próprias políticas adotadas. 
Da mesma forma que seu comportamento teve importantes impactos sobre o desenvolvimento do Proálcool ${ }^{140}$, no final de 1999 nota-se um aumento de procura pelos carros a álcool, devido aos incentivos à demanda proporcionados pelas políticas estaduais e municipais, como também pela vantagem proporcionada pela alta dos preços da gasolina, que tornou o álcool atraente para grande parcela dos consumidores.

Embora o aquecimento do mercado fosse almejado pelos agentes do setor, dado os estoques existentes, começa a haver o receio de que esta demanda torne-se predatória, na medida que foge às estatísticas oficiais (noticia-se que 60.000 motores foram convertidos a álcool, e que muitos consumidores estão misturando álcool hidratado á gasolina nos próprios postos, sem qualquer modificação dos motores), e não permite um planejamento adequado da oferta.

Portanto, o comportamento do consumidor torna essencial a coordenação do setor, em ação conjunta com o setor público, para que não ocorram problemas de desabastecimento (como já ocorreu no passado), o que pode fazer com que os atores envolvidos revejam suas estratégias e voltem a pressionar por revisões nas políticas públicas. Os principais atores envolvidos nos processos decisórios das políticas que afetam o setor sucroalcooleiro, seus recursos e limitações de poder estão no Anexo D.

\footnotetext{
${ }^{140}$ Conforme salientado em Santos (1993), num intervalo de 8 meses houve duas inversões no perfil da demanda: em setembro de 1980 , as vendas de carros a gasolina representavam $66 \%$ das vendas totais, três meses após, eram as vendas de carros a álcool que representavam $76 \%$ das vendas totais; cinco meses mais tarde, em maio de 1981, 71\% das vendas eram novamente de carros a gasolina.
} 


\section{CONCLUSÕES}

A primeira pergunta que se procurou responder neste trabalho é até que ponto o Estado pode e irá se afastar do setor sucroalcooleiro, e caso este afastamento não seja total, quais as novas formas requeridas da ação estatal no novo ambiente desregulamentado.

Para tanto, analisou-se separadamente as características de cada um dos três mercados da cadeia sucroalcooleira - o da cana-de-açúcar, do açúcar, e do álcool - já que cada um apresenta características próprias, e a forma de ação estatal requerida poderia ser diferente.

Se aos produtos citados se incluísse a co-geração de energia elétrica a partir do bagaço de cana-de-açúcar, maior ação do Estado certamente seria necessária. Porém, esta análise mereceria um estudo à parte, dadas as condições requeridas para a expansão da produção de energia elétrica da biomassa. Porém, existem indicações (por exemplo os compromissos assumidos no "Pacto pelo Emprego no setor Sucroalcooleiro") que tanto o Governo Federal como os Estaduais irão desempenhar importantes papéis no sentido de estabelecer a regulamentação e mecanismos que estimulem a co-geração de energia elétrica e sua comercialização.

Em relação aos mercados dos produtos analisados neste estudo, é importante salientar que o pano de fundo da análise dos três é o mesmo, ou seja, o regime político vigente é o democrático, a Constituição atual impede uma ação estatal intervencionista, a economia do País está inserida num mercado globalizado, com tendências liberalizantes, e o Estado, falido, tem dificuldade para implementar políticas públicas que dependam de seus recursos. 
Em relação ao grau de afastamento do Estado do setor sucroalcooleiro, aproximadamente $89 \%$ dos entrevistados considera que não é possível que ele se retire totalmente. Apesar das razões citadas e das formas de atuação requeridas tenham divergido bastante, parece haver consenso de que o governo ainda tem importantes papéis a desempenhar.

Iniciando, com o mercado de cana-de-açúcar, verificou-se que embora as especificidades existentes no produto e as relações historicamente conflituosas entre as duas categorias (fornecedores e industriais) pudessem sugerir a necessidade de intervenção estatal, teoricamente este tipo de ação não se justifica, principalmente quando se considera o ambiente institucional instalado.

Neste caso, o que se espera é que as relações entre as partes sejam regidas por contratos (dada a dependência bilateral existente), e que as eventuais desavenças verificadas sejam resolvidas através da execução dos mesmos na justiça.

Não obstante exista o argumento de que a lentidão dos tribunais dificuita a sua utilização, dados os problemas de perecibilidade da cana, já se nota, no estado de São Paulo, a procura de uma solução privada para resolver a questão da comercialização deste produto. Através da adoção do CONSECANA, as negociações da cana-de-açúcar são feitas por contratos baseados na Lei do Juízo Arbitral, na qual as partes definem os componentes da Câmara de Juízo Arbitral, bem como estipulam os prazos do julgamento, o que ameniza o problema da lentidão dos tribunais.

Outro ponto levantado para justificar a presença do Estado na comercialização da cana-de-açúcar foi que a categoria dos fornecedores é o elo mais fraco da cadeia, e que não tem como competir com os industriais em caso de litígio, já que estes se aproveitam de seu poder econômico para exercer pressão sobre os fornecedores.

Para a resolução deste problema é importante que os produtores se organizem de forma a obter melhores resultados. Se os mesmos se unirem e negociarem conjuntamente, certamente as negociações se darão em bases mais favoráveis para a categoria. Neste sentido, as cooperativas de produtores e as associações de fornecedores têm um papel importante a desempenhar. 
Além disso, no novo ambiente desregulamentado, é essencial a profissionalização das associações de fornecedores, para que as questões de mercado (interno e externo), que tinham pouca importância quando o governo ditava os preços da cana-de-açúcar, sejam analisadas e transmitidas aos seus associados, de forma a reduzir a assimetria de informação existente e permitir um melhor planejamento da produção e comercialização.

Outra solução para a negociação entre fornecedores e industriais poderia ser a utilização de câmaras setoriais (por exemplo, no Estado de São Paulo, a Câmara Setorial do Setor Sucroalcooleiro), nas quais as partes poderiam conversar e negociar, cabendo ao Governo do Estado o papel de coordenador.

Finalmente, se as concentração de mercado existente possibilitar que uma das partes exerça seu poder de mercado, e houver a constatação de abuso de poder econômico, a ação estatal recomendada é a aplicação da legislação antitruste. Neste caso, os agentes podem se utilizar dos mecanismos existentes para tratar da questão através do CADE. O ambiente de livre mercado está sujeito à ação reguladora do Estado, de forma a evitar as práticas desleais de comércio decorrentes do poder de mercado.

A questão da diferença de competitividade agrícola entre as duas regiões produtoras, Norte-Nordeste e Centro-Sul, que faz com que o produtor de cana-de-açúcar da região Norte-Nordeste receba um subsídio, parece ser mais uma questão de política social do que de intervenção setorial. Ao Governo Federal compete analisar as alternativas que dispõe no caso de retirar o subsídio à cana-de-açúcar da região, dados os impactos sociais decorrentes.

Portanto, a conclusão deste trabalho no que se refere ao mercado de cana-deaçúcar é que, dada a dependência bilateral existente entre os agentes e os conflitos que sempre permearam o relacionamento entre as duas categorias, é de que a forma mais eficiente de comercialização da cana-de-açúcar é via contratos.

E que o papel atual do Estado neste elo da cadeia é garantir o funcionamento adequado do livre mercado, através dos seus instrumentos disponíveis (seja como coordenador das câmaras setoriais, ou pela utilização da legislação antitruste existente). 
Desta forma, os agentes devem inserir-se no contexto institucional vigente (no qual a interferència do Estado tem caráter de planejamento indicativo), procurando primeiramente soluções privadas para os conflitos (que podem ter a coordenação estatal), e utilizar-se dos instrumentos disponíveis, em ambiente de livre mercado, em caso de práticas desleais de comércio.

Em relação ao mercado de açúcar, não fosse sua ligação com o mercado do álcool, e a necessidade de derrubar as barreiras externas existentes, o Estado teria seu papel bastante reduzido. As estruturas de mercado encontradas (tanto do lado da oferta como da demanda) são adequadas, os mecanismos de comercialização disponíveis (bolsas de mercadorias e futuros, a utilização de contratos, etc.) parecem atender os agentes de forma satisfatória. Já se verifica inclusive a adoção de estratégias competitivas, tais como a diferenciação de produtos, para atendimento de nichos mercado.

Embora o açúcar seja um produto de cesta básica, que pudesse necessitar do Estado para garantir seu abastecimento em níveis adequados de preço, o fato de ser uma commodity produzida em várias partes do mundo possibilita sua importação em caso de necessidade interna. Além disso, o Governo Federal pode se utilizar do imposto sobre a exportação de açúcar, cuja alíquota varia entre zero e $40 \%$, para garantir o abastecimento interno. Embora atualmente ela esteja zerada, é um importante instrumento para direcionar a produção para o mercado doméstico.

Em relação ao mercado internacional, o Estado tem um papel importante a desempenhar. As negociações externas, que são feitas entre governos, são essenciais para que os países importadores do produto retirem suas restrições às importações, como aqueles que subsidiam suas exportações deixem de fazê-lo. É necessária uma política agressiva para que o Brasil conquiste mercados a que faz juz, principalmente quando se considera a enorme competitividade da agroindústria canavieira.

Como há forte ligação entre a produção de açúcar e de álcool, e como este último dificilmente deixará de ser regulamentado, prevê-se que o mercado de açúcar, se 
não ficar também regulamentado, ficará ao menos indiretamente submetido à interferência do Estado.

Dentre os três mercados analisados, o mercado de álcool combustível, dado o seu caráter estratégico, é o que mais requer requer a intervenção estatal. Primeiramente porque a preços de mercado, sem se considerar as externalidades do produto, o álcool não compete com a gasolina porque seus custos de produção são maiores. A partir de agosto de 2.000 se encerra o mecanismo de suporte ao produto existente (através da PPE), bem como serão liberados os preços dos combustíveis nas refinarias de petróleo.

Desta forma, a viabilidade do álcool combustível fica dependendo de fatores conjunturais, como por exemplo do nível de preços do petróleo no mercado internacional, da taxa de câmbio do real em relação ao dólar, dos acordos firmados com o FMI no que se refere a política interna de preços dos derivados de petróleo, etc.

Do mesmo modo que esta relação de preços pode tornar o álcool combustível extremamente atraente para o consumidor (que é muito sensível à diferença de preços entre os dois combustíveis), na situação inversa pode inviabilizar sua produção e comprometer o abastecimento.

O nível de preços do petróleo no final de 1999 (em torno de US\$20 dólares o barril), que muitos consideram compatíveis com os seus níveis de depleção, tornam o álcool combustível viável em termos empresariais, mesmo sem se considerar suas externalidades positivas. Mas a utilização de diferentes combustíveis pela sociedade não pode depender somente dos seus preços relativos, ditados por fatores conjunturais.

É necessário que o Estado defina a política energética a ser adotada no País, e elabore a sua matriz energética. E esta é uma questão primordial da qual o Estado não pode se afastar, e que afeta todo o planejamento do setor. É preciso que se deixe claro para a sociedade qual é o papel destinado a cada um dos combustíveis num horizonte de longo prazo.

Portanto, a partir da definição da matriz energética, que deve considerar as novas tecnologias existentes (por exemplo a existência de ônibus movidos a álcool, a adição de álcool no diesel, o uso de células de combustível, que tem o etanol como 
matéria-prima, a celulose como base para qualquer álcool, etc.), é possível a organização e planejamento da produção de álcool, o que se torna particularmente importante quando se considera que este produto é feito a partir de matéria-prima agrícola (envolvendo toda a cadeia da cana-de-açúcar).

Além disso, para assegurar a oferta dos combustíveis adequada à demanda, é necessário que os preços relativos dos produtos direcionem os consumidores de forma a atender a política energética estabelecida. O preço do álcool combustível deve ser compatível com seus custos de produção e ser atrativo para o consumidor. Porém, ao mesmo tempo, deve possibilitar que se atenda o patamar de utilização deste combustível pré-estabelecido pela matriz energética brasileira.

Portanto, o Estado necessita de instrumentos que tornem possível o direcionamento da demanda entre os combustíveis alternativos, que é um papel importante a ser desempenhado por ele.

Dentre os instrumentos possíveis, estão os mecanismos tributários. Tanto o Governo Federal como o Estadual podem adotar sistemas de tributação que incidam de forma diferenciada sobre os combustíveis, de forma a direcionar sua utilização.

O Governo Federal pode se utilizar de um imposto seletivo sobre os combustíveis, conforme existe em outros países, se quiser incentivar o uso de combustíveis não poluentes. Por sua vez, o Governo Estadual pode adotar alíquotas de ICMS diferenciadas sobre os combustíveis e sobre os automóveis, para adequar o uso dos combustíveis aos patamares pré-estabelecidos pela política energética.

Outra questão que afeta o funcionamento deste mercado é o oligopsônio encontrado no mercado de distribuição (embora atualmente existam aproximadamente 170 distribuidoras de combustíveis, aquelas afiliadas ao Sindicom ainda detém mais de $80 \%$ do mercado), que faz com que os aproximadamente 300 produtores de álcool enfrentem dificuldades para comercializar seu produto em níveis de preços adequados.

Porém, da mesma forma que a diferença competitiva entre fornecedores e industriais não é justificativa para que o Estado intervenha na comercialização da canade-açúcar, a estrutura de mercado concentrada no mercado de distribuição não se 
resolve, em ambiente de livre mercado, através da regulamentação da comercialização. A solução pode vir através do fortalecimento da classe produtiva, que ao se organizar pode encontrar melhores condições de negociação, ou pelos mecanismos disponíveis que existem para evitar práticas desleais de comércio, oriundos da legislação antitruste, através da ação do CADE.

É interessante notar que neste segmento houve uma ação privada visando o fortalecimento da classe de produtores. Os industriais se uniram e criaram a Bolsa Brasileira de Álcool, na qual a comercialização do álcool é feita conjuntamente. Desta forma, a paridade entre os dois agentes, produtores e distribuidoras, tornou possível uma negociação melhor, dificultando as práticas desleais de comércio.

Por sua vez, se for constatado abuso de poder de mercado, tanto a conduta da Bolsa Brasileira de Álcool (que pode se tornar ineficiente, dado o aumento de seu poder de mercado resultante da alta concentração da comercialização), como a das distribuidoras agrupadas no Sindicom, são passíveis de intervenção do CADE, que se utilizará da legislação antitruste em vigor.

Outra dificuldade existente no mercado de álcool combustível advém da sazonalidade da produção deste produto (que é feito a partir de matéria-prima agrícola), sendo que a produção é realizada em 6 meses para ser comercializada ao longo do ano, implicando em elevados custos de armazenamento.

Na época da safra, na qual a necessidade de recursos dos produtores aumenta, a oferta de álcool no mercado é superior à demanda, fazendo com que os preços do produto se reduzam bastante. Novamente a organização dos produtores, através da Bolsa Brasileira de Álcool, permitiu que o problema fosse amenizado através da busca de uma solução privada.

$\mathrm{O}$ fato dos produtores que aderiram a BBA só poderem vender através desta empresa, melhorou o problema da distribuição de oferta ao longo do ano, já que as vendas são feitas através de um rateio da demanda mensal entre os produtores. Porém, embora haja um maior controle sobre as vendas mensais, é claro que os problemas dos custos de estocagem ainda existem e necessitam de solução. 
Os custos de estocagem podem ser financiados pelo Governo Federal através operações de warrantagem (que permitam a retenção dos estoques, através de empréstimos a juros menores); ou pelos próprios produtores, através da securitização dos recebíveis, que corresponde a um adiantamento aos produtores que tenham contratos com as distribuidoras para os próximos meses.

Além disto, é importante que dentre os mecanismos utilizados para aumentar a liquidez dos produtores, e também para se precaver das grandes oscilações de preços ocorridas ao longo do ano, seja considerada a utilização do mercado futuro para o álcool combustível (através da BM\&F, tal como já existe para o açúcar).

Também cabe ao setor tentar captar parte do considerável volume de recursos existente no mercado de carbono, no qual existem grandes possibilidades de financiamento externo para a agroindústria canavieira, dada sua contribuição positiva para a redução das emissões de $\mathrm{CO}_{2}$.

A questão da formação de estoques estratégicos do governo merece ser reavaliada, comparando-se os custos envolvidos, a eficiência da operação e as alternativas existentes. Deve ser considerado se não é mais eficiente que o governo financie os estoques privados, ou adote mecanismos mais modernos de apoio à produção.

Porém, os produtores devem ter consciência do tamanho do mercado do álcool combustível, e do volume de álcool que o governo está disposto a suportar. O planejamento da produção é importante para evitar o excesso de oferta, já que existem recursos públicos envolvidos, e há um limite para sua utilização.

Para tanto, é necessário uma sinalização aos agentes do mercado, incluindo o governo, sobre as expectativas da demanda e da produção de açúcar e de álcool, para que o planejamento possa ser feito forma a assegurar a oferta adequada.

Esta sinalização sobre a demanda, e sobre as necessidades de produção, é de responsabilidade do Ministério das Minas e Energia. A partir da indicação da oferta necessária para abastecer o mercado, o setor privado deve, através dos seus Sindicatos, se organizar, planejar e adequar sua produção. 
$\hat{E}$ importante que exista um monitoramento mensal da demanda e produção realmente realizadas (num trabalho conjunto da iniciativa privada com o governo), de tal forma que ao longo do tempo elas estejam ajustadas. Desta forma, a partir do acompanhamento mensal dos dados, os industriais podem (re)planejar sua produção de forma a atender as necessidades do mercado.

A partir do monitoramento mensal, se necessário, o Governo Federal pode se utilizar dos instrumentos disponíveis para tomar medidas preventivas que garantam o abastecimento dos produtos (por exemplo através da elevação da taxa de exportação de açúcar). É claro que o Governo Federal deve ter a competência para filtrar os dados apresentados, de modo a torná-lo o mais próximo da realidade possível.

Os problemas de adulteração dos combustíveis e de sonegação fiscal que permearam a desregulamentação do setor de combustíveis, incluindo o mercado distribuição, parece estar equacionado através da Agência Nacional do Petróleo. Embora a eficácia das ações tomadas pela agência seja questionada, bem como a importância relativa do álcool combustível dentro da Agência Nacional do Petróleo, trata-se de torná-la efetiva para conseguir solucionar os problemas que se apresentam.

Portanto, vemos que no mercado do álcool o Estado ainda tem um papel importante a desempenhar, porém condizente com o novo ambiente institucional. Dentre as principais ações do Governo Federal estão: a definição da matriz energética brasileira; a divulgação da demanda estimada e monitoramento dos níveis adequados de produção de álcool; o direcionamento da produção entre álcool e açúcar de forma a atender as demandas dos produtos; a definição de um mecanismo tributário que permita a convivência dos dois combustíveis em níveis pré-fixados pela política energética; a utilização de mecanismos tributários (por exemplo, IPI) para adequar o uso do combustível alternativo; o apoio à formação dos estoques; e a promoção da abertura do mercado externo para os produtos da cadeia sucroalcooleira.

Os Governos Estaduais devem usar os mecanismos tributários (ICMS) sobre os combustíveis e os automóveis, de forma a atender as demandas esperadas pelos combustíveis; atuar como coordenadores das Câmaras Setoriais, e, da mesma forma que 
o Governo Federal, monitorar a auto-gestão da cadeia sucroalcooleira e dos agentes envolvidos no mercado de combustíveis (cadeia automobilística e de combustíveis), considerando as questōes de emprego e renda envolvidas em cada Estado.

Desta forma, conclui-se que o afastamento do Estado deve ser substituído por novos mecanismos de coordenação setorial, cabendo aos governos (Federal e Estaduais) o papel de coordenadores. Neste sentido, o "Pacto pelo Emprego do Negócio Sucroalcooleiro", firmado no Estado de São Paulo, foi uma evolução importante, cujo desenvolvimento dependerá das relações econômicas e sociais emergentes, que devem beneficiar as cadeias produtivas como um todo.

Porém, para que ele realmente funcione, é imprescindivel que todos os agentes envolvidos realmente cumpram as responsabilidades assumidas. A capacidade das associações se auto governarem dificilmente surge se não existir a autoridade, de modo a induzir certos comportamentos e proibir outros. Portanto, são necessários instrumentos que permitam a avaliação e cobrança dos deveres assumidos por cada agente, principalmente quando se considera o número de agentes envolvidos (cadeia sucroalcooleira, cadeia automobilística, cadeia dos combustíveis, Goveno Federal, Estadual, Municipal).

Por sua vez, para que os mecanismos de auto-gestão da cadeia sucroalcooleira se mostrem eficientes, o setor deve vencer um grande desafio, já que a união de seus agentes não é característica marcante de sua história, que sempre se mostrou permeada de conflitos.

A grande questão que se coloca é se um setor que durante 60 anos viveu sobre a égide do Estado, que agora necessita organizar sua produção, de modo a adequá-la ao mercado, e ao mesmo tempo enfrenta interesses diversos dos agentes, está realmente amadurecido para se coordenar e buscar um projeto comum.

Outras questões que procurou-se verificar neste trabalho foram quais os agentes que influenciaram o processo de desregulamentação, e quais os motivos de tantas prorrogações. E, a partir do novo ambiente institucional, quais os principais atores, seus 
recursos de poder, e arenas decisórias relevantes nas determinações das políticas públicas relativas ao setor.

Durante o processo de desregulamentação, a arena decisória a qual os diferentes atores canalizavam suas demandas, e era o principal responsável pelas políticas do setor era o CIMA, que foi o conselho que assessorou o Ministro Pedro Malan nas suas decisões sobre a liberação.

Os diversos atores envolvidos tinham acesso ao CIMA através do seu Conselho Consultivo, do qual faziam parte representantes das diversas correntes, desde os mais liberais, claramente a favor da desregulamentação, até aqueles que gostariam a volta do sistema centralizado nas mãos do Governo. Da mesma forma os parlamentares, que no novo cenário democrático tiveram seu poder aumentado, representavam suas regiões e interesses no Conselho Consultivo.

Portanto, embora as decisões do CIMA considerassem as opiniões de sua Câmara Técnica, certamente as deliberações emergentes eram resultado das pressões dos diversos atores, cada qual defendendo seus interesses. Dentre os atores destacam-se as associações de produtores da região Centro-Sul (UNICA, CEPAAL, SOPRAL), os sindicatos de produtores de açúcar e álcool da região Norte-Nordeste, associações de fornecedores de cana (FEPLANA, ORPLANA), e os parlamentares das diversas regiões produtoras.

Desta forma, os diversos adiamentos ocorridos podem ser explicados tanto pelas condições conjunturais de mercado existentes, que traziam muita dificuldade para toda a cadeia sucroalcooleira, como pela diversidade de opiniões dos agentes que tinham influência sobre o processo.

A partir da desregulamentação, uma questão interessante é a identificação das arenas decisórias, dos agentes e seus recursos de poder, que compõe os determinantes políticos dos processos decisórios.

Deve ser lembrado que a desregulamentação do setor insere-se num quadro institucional mais amplo, no qual o regime político vigente é o democrático, a Constituição reduz o poder intervencionista do Estado, a economia do País está inserida 
num mercado globalizado, com tendências liberalizantes, e o Estado praticamente não dispõe de recursos para implementação de políticas públicas.

Desta forma, neste cenário, os principais atores determinantes das políticas públicas para o setor são os seguintes: os parlamentares do Congresso Nacional, os municípios, os Sindicatos de Trabalhadores, e os Governos Estaduais. O Governo Federal, que na fase de elaboração do Proálcool teve o papel principal, tem seu poder bastante reduzido, sendo suas ações canalizadas através do CIMA e da ANP.

Os consumidores, por sua vez, embora não tenham atuação direta na determinação das políticas, influenciam as tomadas de decisão por serem extremamente sensíveis aos preços relativos dos combustíveis.

Os atores que participaram da fase de elaboração e implementação do Proálcool, quando as decisões eram extremamente centralizadas nas mãos do Executivo, e quando as relações pessoais eram determinantes para as escolhas de políticas públicas, sentem dificuldade em se adaptar à nova forma de tomadas de decisão do regime democrático, que prioriza a discussão entre todos os agentes envolvidos. 


\section{ANEXOS}

Anexo A - Integrantes do CIMA (maio de 1999)

- Ministros

Celso Lafer - Desenvolvimento, Indústria e Comércio;

Pedro Malan - Fazenda;

Francisco Turra - Agricultura;

Rodolfo Tourinho Neto - Minas e Energia;

José Sarney Filho - Meio Ambiente;

Luiz Felipe Lampreia - Relações Exteriores;

Luis Carlos Bresser Pereira -- Ciência e Tecnologia;

Clóvis Carvalho - Casa Civil;

Pedro Pulen Parente - Orçamento e Gestão;

Ronaldo Mota Sardenberg - Extraordinário de Projetos Especiais.

\section{- Comitê Executivo}

Formado pelos Secretários Executivos dos seguintes Ministérios:

Bolivar Rocha Moura - Desenvolvimento, Indústria e Comércio;

Amaury Guilherme Bier - Fazenda;

Ailton Barcelos - Agricultura;

José Luiz Peres Garrido - Minas e Energia;

José Carlos Carvalho - Meio Ambiente;

Luis Felipe de Seixas Corrêa - Relações Exteriores;

Américo Pacheco - Ciência e Tecnologia;

Silvano Gianni - Casa Civil;

Martus Tavares - Orçamento e Gestão. 


\section{Anexo A - continuação}

\section{- Comitê Consultivo}

Representantes dos Produtores de Açúcar e Álcool:

José Ranulfo Queiros Neto - Presidente do Sindicato da Indústria do Açúcar e do Álcool do Estado de Pernambuco;

Jorge Toledo Florêncio - Presidente do Sindicato da Indústria do Açúcar e do Álcool do Estado de Alagoas;

Gustavo da Costa Maranhão - Presidente da Associação Brasileira da Indústria do Álcool (ALCO);

Werther Annichino - Membro do Conselho de Administração da COPERSUCAR;

Ermeto Barea - Representante produtores Paraná

Luis Custódio Cotta Martins - Presidente do Sindicato da Indústria do Açúcar e do Álcool do Estado de Minas Gerais.

Representantes dos fornecedores de cana:

Antonio Celso Cavalcante de Andrade - Presidente da Federação dos

Plantadores de Cana do Brasil - FEPLANA

Edison José Ustulin - diretor da ORPLANA;

José de Souza Mota;

Edgar Antunes Neto.

Parlamentares da Câmara dos Deputados:

Roberto Balestra - PPB - Goiás

Francisco Graziano - PSDB - São Paulo

José Múcio - PFL - Pernambuco

João Caldas - PMN - Alagoas 
Anexo $\mathrm{A}$ - continuação

Senadores:

Geraldo Mello - RN

Jonas Pinheiro - MT

- Câmara Técnica

Elizabete Seródio - então Diretora do Departamento de Álcool e Açúcar do Ministério do Desenvolvimento, Indústria e Comércio;

Carlos Orlando - Ministério do Desenvolvimento, Indústria e Comércio;

Paulo Motoki - Consultoria privada, representando, na época, a SOPRAL;

Plínio Nastari - Presidente DATAGRO,;

Pedro Robério - Consultoria privada; representando a Cooperativa de Alagoas;

Geraldo Magela - ORPLANA;

Ricardo Dornelles - ANP;

Aluísio Nunes - COPERSUCAR;

Luíz Carlos Correa Carvalho - Canaplan e Superintendente UNICA;

Antônio de Pádua Rodrigues - Canaplan e UNICA;

Luiz Milton Veloso da Costa - Ministério da Fazenda;

Eliana Fernandes - ANP;

Luciano Castro - Sindicato dos Produtores de Minas Gerais;

Cláudio Penna - Sindicato dos Produtores de açúcar de Pernambuco;

Sérgio Leite - Sindiquímicos - SP.

\section{- Sub-grupo de Comercialização:}

Cláudio Monteiro Considera - Secretário de Acompanhamento Econômico do Ministério da Fazenda;

Luiz Milton Veloso Costa - Secretário Adjunto de Acompanhamento Econômico - Ministério da Fazenda;

David Zylbersztajn - Diretor da Agência Nacional de Petróleo; Júlio Colombini Netto - Diretor da Agência Nacional do Petróleo; 
Anexo A - continuação

Ivonice Aires Campos - Secretária de Desenvolvimento Científico e Tecnológico - MCT

Aloísio Sotero - Superintendente SUDENE 


\section{Anexo B - O modelo CONSECANA}

O cálculo do ATR é resultante dos parâmetros básicos que definem a qualidade da matéria-prima, através da seguinte fórmula (Silva, 1998):

$$
A T R=9,26288 \cdot P C+8,8 \cdot A R
$$

onde:

ATR = Açúcar Total Recuperável, expresso em $\mathrm{kg} / \mathrm{t}$;

$P C=$ Pol \% Cana

$A R=$ Açúcares Redutores \% Cana, calculados pela seguinte equação:

$$
A R=(9,9408-0,1049 \cdot P z a) \cdot(1-0,01 F) \cdot(1,0313-0,00575 F)
$$

onde:

Pza $=$ Pureza do caldo extraído

$\mathrm{F}=$ Fibra $\%$ da cana

Conforme o autor, os parâmetros tecnológicos que definem a qualidade da matéria-prima continuarão sendo apurados na usina ou destilaria onde a cana for entregue, no ato da entrega. O valor da tonelada da cana será expresso através da seguinte fórmula:

$$
V T C=k g d e A T R / t . P \% . V A T R
$$

onde:

$V T C=$ Valor base, em reais, exclusive tributos, de uma tonelada de cana, posta na esteira da unidade industrial;

$A T R=$ Açúcar Total Recuperável, entregue pelo produtor de cana;

$p \%$ = Participação média da matéria-prima no ATR entregue, ponderada em função do

Mix de produção (açúcar + álcool residual, álcool anidro e hidratado);

VATR = Valor médio do ATR, obtido em nível estadual, e ponderado em função da comercialização do açúcar, nos mercados estadual e externo, do álcool anidro e hidratado.

O valor final da tonelada da cana será obtido com a adição dos tributos. 


\section{Anexo C - O Pacto pelo Emprego no Agronegócio Sucroalcooleiro}

As principais responsabilidades assumidas por cada setor estão listadas a seguir:

3.1 Governo Federal:

- Monitorar a execução das políticas acordadas pelos agentes do pacto, compatibilizando a fabricação de produtos e subprodutos da cana-de-açúcar, de forma a garantir o abastecimento interno;

- abrir novos mercados para exportação de álcool carburante, especialmente para aqueles países que o Brasil é grande importador de produtos agrícolas;

- lutar contra barreiras protecionistas de países que subsidiam seus produtos deste setor;

- lutar contra a sonegação fiscal no álcool, em ação conjunta com o Governo do Estado;

- realizar investimentos para garantir a qualidade do combustível a apoiar a logística de combustíveis e prestação de serviços ao consumidor;

- estabelecer normas operacionais para a comercialização do álcool hidratado no varejo, sendo que os postos que optarem por adoção de uma bandeira, deverão comercializar o álcool da respectiva distribuidora;

- garantir que a comercialização do hidratado seja feita somente de distribuidora autorizada pela ANP;

- adoção de medidas de estímulo à demanda, tais como: implementação do uso da frota verde (movidas a álcool); implantar a mistura de $26 \%$ de anidro com a gasolina; completar as pesquisas de mistura de $3 \%$ de álcool no diesel; manter a isenção do IPI para os táxis a álcool e estende-la para as locadoras de veículos;

- adotar medidas compensatórias que permitam o tratamento diferenciado aos combustíveis anidro e hidratado;

- estabelecer regulamentação e mecanismos que estimulem a co-geração de energia elétrica a partir de bagaço da cana e sua comercialização;

- manter estoque regulador de álcool, pela compra ou pela gestão do nível da mistura. 
Anexo C - O Pacto pelo Emprego no Agronegócio Sucroalcooleiro - continuação

3.2 Governo do Estado de São Paulo:

- monitorar, no âmbito da Câmara paulista do Setor Sucroalcooleiro, as medidas pactuadas e criar mecanismos adequados para garantir o alcance das metas estabelecidas;

- viabilizar a redução da alíquota de ICMS incidente do álcool hidratado com aumento compensatório sobre a da gasolina, visando a redução da sonegação e como forma de contribuir para uma relação equilibrada entre preços de álcool e gasolina;

- adoção de medidas de estímulo à demanda, tais como: implementação do uso da frota verde (movidas a álcool); conceder isenção do IPVA até o ano 2.000, para veículos novos, movidos a álcool, adquiridos em 1999; testar a mistura de 3\% de álcool no diesel em municípios canavieiros; trabalhar pela isenção do ICMS para os táxis a álcool e para as locadoras de veículos, reconduzindo a questão no âmbito do CONFAZ;

- estimular a implantação de projetos de co-geração de energia elétrica em usinas e destilarias de álcool;

- participar dos programas e das iniciativas para requalificação dos trabalhadores do setor sucroalcooleiro.

3.3 Governos municipais integrantes da AMCESP:

- determinar que as frotas oficiais sejam a álcool e estimular a utilização do álcool no transporte coletivo após a comprovação de sua economicidade;

- realizar esforços no sentido de manter os trabalhos, e relacionados à formaçăo profissional dos trabalhadores do setor;

- desenvolver esforços para excluir os veículos a álcool dos sistemas de rodízios. 


\section{Anexo C - O Pacto pelo Emprego no Agronegócio Sucroalcooleiro - continuação}

3.4 Industriais do setor:

- garantir o abastecimento dos mercados consumidores, assegurando oferta de álcool e demais produtos derivados da cana-de-açúcar, de acordo com a demanda acordada na Câmara Paulista do Setor Sucroalcooleiro e com o Governo Federal;

- investir em pesquisa e desenvolvimento e na difusão do conhecimento, promover a sanidade da cultura e treinamento dos trabalhadores, objetivando ganhos de competitividade e proteção à saúde do trabalhador

- apoiar os programas que promovam o uso do álcool carburante e as iniciativas para estimular o mercado de veículos a álcool, com, o objetivo de se atingir $15 \%$ nas vendas totais da indústria automobilística;

- manutenção dos empregos existentes em 1 de julho de 1999, e buscar soluções de longo prazo para geração e manutenção da oferta de trabalho nos anos subseqüentes;

- estabelecer parcerias com o governo e trabalhadores para a reciclagem da mãode-obra;

- assegurar a continuidade à assistência social aos trabalhadores da agroindústria;

- contratar mão-de-obra somente em sua área de influência;

- Limitar a expansão da colheita mecânica de cana-de-açúcar à cana crua;

- apoiar os programas que incentivem o uso do álcool carburante;

- esforços para estabelecer projetos de co-geração e venda de energia elétrica;

- comercializar álcool somente com as distribuidoras autorizadas pela ANP

- doação de 1.000 litros de álcool para os compradores de veículos em 1999;

- buscar equilíbrio entre os agentes da cadeia e adotar o modelo de auto-gestão para o fornecimento de cana-de-açúcar definido pelo CONSECANA;

- estimular o aumento da participação dos fornecedores no suprimento de canade-açúcar;

- respeitar o meio-ambiente. 


\section{Anexo C - O Pacto pelo Emprego no Agronegócio Sucroalcooleiro - continuação}

\subsection{Fornecedores da cana:}

- garantir o fornecimento de cana-de-açúcar e adptar o modelo de auto-gestão estipulado pelo CONSECANA-SP;

- investir em pesquisa e desenvolvimento, difusão do conhecimento, e na qualificação dos trabalhadores, objetivando ganhos de competitividade;

- adequar os sistemas de produção de modo a respeitar a legislação ambiental;

- manutenção dos empregos existentes em 1 de julho de 1999, e buscar soluções de longo prazo para geração e manutenção da oferta de trabalho nos anos subseqüientes;

- assegurar a continuidade à assistência social aos trabalhadores da agroindústria;

- contratar mão-de-obra somente em sua área de influência;

3.6 As federações de trabalhadores:

- elaborar em parceria com o governo, produtores e industriais, um programa específico de requalificação profissional para os trabalhadores da agroindústria canavieira, utilizando recursos de todas as fontes disponíveis nos governos, organizações e setor privado (FAT, Senar, Senai, Fundacentro, Sebrae e outros);

- acompanhar o pacto do ponto de vista da geração de empregos e trabalho, respeitadas as condições econômicas e boas relações capital-trabalho.

3.7 As distribuidoras de combustíveis:

- otimização do suprimento de álcool, através da infra-estrutura de distribuição adequada aos volumes comercializados, dentro das normas de segurança, qualidade e proteção ao meio-ambiente. 


\section{Anexo C - O Pacto pelo Emprego no Agronegócio Sucroalcooleiro - continuação}

3.8 Montadoras:

- produzir e manter o mercado abastecido de veículos a álcool conforme a demanda verificada, respeitadas as condições de mercado;

- continuidade das pesquisas para o desenvolvimento do carro a álcool. 
Anexo D. Os atores e os recursos de poder envolvidos nos processos decisórios das politicas relativas ao setor sucroalcooleiro.

\begin{tabular}{|c|c|c|c|c|}
\hline \multicolumn{2}{|c|}{ Atores } & $\begin{array}{l}\text { Poder } \\
\text { Atual }\end{array}$ & Recursos de Poder & Limites de Poder \\
\hline \multirow{3}{*}{$\begin{array}{l}\text { Executivo } \\
\text { Federal }\end{array}$} & $\begin{array}{l}\text { Presidente da } \\
\text { República }\end{array}$ & Baixo & $\begin{array}{l}\text { Incentivo ao combustível } \\
\text { renovável, não poluente }\end{array}$ & $\begin{array}{l}\text { Outras prioridades } \\
\text { (estabilidade monetária, } \\
\text { controle inflação, ajuste } \\
\text { fiscal) }\end{array}$ \\
\hline & CIMA & Alto & $\begin{array}{l}\text { Centralização das } \\
\text { decisões, canal de } \\
\text { comunicação dos } \\
\text { produtores; fórum de } \\
\text { discussão, instrumentos } \\
\text { próprios de política }\end{array}$ & Falta de recursos \\
\hline & ANP & Alto & $\begin{array}{l}\text { Regulamentação e } \\
\text { fiscalização dos merca- } \\
\text { dos de combustíveis; } \\
\text { executor das políticas } \\
\text { referentes ao setor (for- } \\
\text { mação estoques regula- } \\
\text { dores) instrumentos } \\
\text { próprios de política }\end{array}$ & $\begin{array}{l}\text { Outras prioridades } \\
\text { (abrir monopólio } \\
\text { Petrobrás; combustíveis } \\
\text { fósseis), falta } \\
\text { instrumentos } \\
\text { adequados para } \\
\text { fiscalização }\end{array}$ \\
\hline \multirow[t]{2}{*}{$\begin{array}{l}\text { Executivos } \\
\text { Estaduais }\end{array}$} & Governadores & Alto & $\begin{array}{l}\text { Representação interesses } \\
\text { estaduais frente ao } \\
\text { Governo Federal, } \\
\text { capacidade articulação } \\
\text { política, instrumentos } \\
\text { próprios de política }\end{array}$ & $\begin{array}{l}\text { Limitações de recursos, } \\
\text { guerra fiscal entre os } \\
\text { estados; }\end{array}$ \\
\hline & $\begin{array}{l}\text { Secretários } \\
\text { Estaduais de } \\
\text { Agricultura }\end{array}$ & Alto & $\begin{array}{l}\text { Poder dos respectivos } \\
\text { governadores; } \\
\text { capacidade de ação } \\
\text { coordenada }\end{array}$ & $\begin{array}{l}\text { Falta de instrumentos } \\
\text { próprios de política }\end{array}$ \\
\hline $\begin{array}{l}\text { Executivos } \\
\text { Municipais }\end{array}$ & Prefeitos & Alto & $\begin{array}{l}\text { Representação interesses } \\
\text { municipais frente ao } \\
\text { Governo Estadual, } \\
\text { capacidade de articula- } \\
\text { ção política, instrumen- } \\
\text { tos próprios de política }\end{array}$ & \\
\hline $\begin{array}{l}\text { Congresso } \\
\text { Nacional }\end{array}$ & $\begin{array}{l}\text { Senadores e } \\
\text { Deputados }\end{array}$ & Alto & $\begin{array}{l}\text { Barganha entre políticas } \\
\text { e apoio político ao } \\
\text { executivo; acesso ao } \\
\text { Executivo, audiências } \\
\text { públicas; demanda por } \\
\text { regulamentação e } \\
\text { execucão das políticas }\end{array}$ & $\begin{array}{l}\text { Falta de preparo } \\
\text { específico dos } \\
\text { parlamentares, } \\
\text { dificuldades de atuar } \\
\text { como bancada }\end{array}$ \\
\hline
\end{tabular}

Obs: continua próxima página 
Anexo 5. Os atores e os recursos de poder envolvidos nos processos decisórios das políticas relativas ao setor sucroalcooleiro - continuação

\begin{tabular}{|c|c|c|c|c|}
\hline \multirow{2}{*}{$\begin{array}{l}\text { Associações } \\
\text { de Classe e } \\
\text { Sindicatos de } \\
\text { Produtores }\end{array}$} & Industriais & $\begin{array}{l}\text { Médio a } \\
\text { Alto }\end{array}$ & $\begin{array}{l}\text { Acesso ao CIMA; acesso } \\
\text { ao Governo do Estado, } \\
\text { articulação com } \\
\text { parlamentares }\end{array}$ & $\begin{array}{l}\text { Dificuldade de } \\
\text { coordenação, grupos } \\
\text { muito amplos, } \\
\text { dispersos e } \\
\text { heterogêneos, falta de } \\
\text { legitimidade junto } \\
\text { opinião pública } \\
\end{array}$ \\
\hline & Fornecedore & $\begin{array}{l}\text { Médio a } \\
\text { Alto }\end{array}$ & $\begin{array}{l}\text { Acesso ao CIMA; } \\
\text { articulação com } \\
\text { parlamentares; } \\
\text { legitimidade junto } \\
\text { opinião pública }\end{array}$ & $\begin{array}{l}\text { Dificuldade de } \\
\text { coordenação entre as } \\
\text { duas regiões produtoras }\end{array}$ \\
\hline \multirow{3}{*}{$\begin{array}{l}\text { Sindicatos de } \\
\text { Trabalhadores }\end{array}$} & Alimentação & Alto & $\begin{array}{l}\text { Legitimidade junto } \\
\text { opinião pública; apelo } \\
\text { social }\end{array}$ & $\begin{array}{l}\text { Dificuldade em } \\
\text { conseguir aliados } \\
\text { urbanos }\end{array}$ \\
\hline & $\begin{array}{l}\text { Química } \\
\text { farmacêutic } \\
\text { a }\end{array}$ & Alto & $\begin{array}{l}\text { Legitimidade junto } \\
\text { opinião pública; apelo } \\
\text { social }\end{array}$ & \\
\hline & Metalúrgica & Alto & $\begin{array}{l}\text { Legitimidade junto } \\
\text { opinião pública; apelo } \\
\text { social }\end{array}$ & $\begin{array}{l}\text { Legitimidade junto } \\
\text { opinião pública }\end{array}$ \\
\hline Montadoras & & Médio & $\begin{array}{l}\text { Acesso aos Governos } \\
\text { (estadual e federal) }\end{array}$ & \\
\hline Distribuidoras & & $\begin{array}{l}\text { Médio a } \\
\text { Alto }\end{array}$ & & \\
\hline Consumidores & & Alto & $\begin{array}{l}\text { Grande influência sobre } \\
\text { a demanda }\end{array}$ & \\
\hline
\end{tabular}

Elaborado a partir de Lamounier (1994). 


\section{REFERÊNCIAS BIBLIOGRÁFICAS}

AMARAL, W.A.N. Mudanças climáticas, mercado de carbono e potencialidades do Brasil para o desenvolvimento de projetos para o mecanismo de desenvolvimento limpo. Preços Agrícolas, v.14, n.155, p.7-9, set. 1999.

ANUÁRIO JORNALCANA - Safra 97/98 - v. Centro-Sul e Norte-Nordeste, 1998.

ASSOCIAÇÃO BRASILEIRA DA INDÚSTRIA DO ÁLCOOL. Missão técnica sobre políticas do álcool combustível. Brasília, 1997. (Relatório de visita).

ALSTON, L. J. A framework for understanding the New Institutional Economics. In: SEMINÁRIO BRASILEIRO SOBRE A NOVA ECONOMIA INSTITUCIONAL, 1., São Paulo, 1998. Anais. São Paulo: Universidade de São Paulo, 1998. 22p.

ARROW, K. The organization of economic activity: issues pertinent to the choice of market versus non-market allocation. In: ANALYSIS AND EVALUATION OF PUBLIC EXPENDITURE, 91. Proceedings, v.11. Washington: U.S. Government Printing Office, 1969. p.59-73.

BARROS, G.S.C. Novas estratégias de gerenciamento de riscos e financiamento do agronegócio. Preços Agrícolas, v.14, n.152, p.9-10, jun. 1999.

BEST, M. The new competition: institutions of industrial reestructuring. Cambridge: Harvard University Press, 1990. 296 p.

BOLSA DE MERCADORIAS \& FUTUROS. Formação do preço do açúcar: operações estratégicas. São Paulo: BM\&F, 1997. 17p.

BURQUINST, H.L. Plano de Safra $1997 / 98$ para o setor sucroalcooleiro. Preços Agrícolas, v.11, n.128, p.21-24, jun. 1997.

BURQUINST, H.L.; BACCHI, M.R.P. O açúcar na política agrícola dos EUA e $o$ Farm Act de 1996. Preços Agrícolas, v.11, n. 122, p.18-22, dez. 1996.

BURQUINST, H.L.; BACCHI, M.R.P. Tendências do mercado internacional de açúcar.

Preços Agrícolas, v.11, n.128, p.17-20, jun. 1997. 
CARRUTHERS, I.; KYDD, J. The development and direction of agricultural development economics. Journal of Agricultural Economics, n.48, v.2, p-223-238, 1997.

CARLTON B.; PERLOFF, J. Modern industrial organization. 2.ed. New York: Harper Collins College Publishers, 1994.973 p.

CARVALHO, L.C.C. Mercado nacional e internacional do açúcar e do álcool. In: SEMANA DA CANA-DE-AÇÚCAR DE PIRACICABA, Piracicaba, 1997. Anais. Piracicaba, 1997. p.16-28.

CHAVES, L. R. G.; SEMERENA, R.E. La agroindústria azucarera de México em el marco de la apertura. Comércio Exterior, p.975-983, dec. 1997.

COASE, R.H. The problem of social cost. Journal of Law and Economics, n.3, p.1-44.

COASE, R.H. The regulated industries: discussion. American Economic Review, v.54, n.3, p.194-197, 1964.

CORAL, J. Modelo de autogestão e as indefinições do governo. Preços Agrícolas, v.12, n. 141, p.3, jul. 1998.

FARINA, E.M.M.Q. Desregulamentação e o controle do abuso do poder econômico: teoria e prática. Revista de Economia Política, v.14, n.3, p.78-93, jul./set. 1994.

FARINA, E.M.M.Q. Reflexões sobre desregulamentação e sistemas agroindustriais: a experiência brasileira. São Paulo, 1996. 156p. Tese (Livre-Docência) - Faculdade de Economia, Adminstração e Contabilidade, Universidade de São Paulo.

FARINA, E.M.M.Q.; AZEVEDO, P. F., SAES, M.S.M. Competitividade: mercado, estado e organizações. São Paulo: Singular, 1997. 285p.

FURQUIM, P. A. Integração vertical e barganha. São Paulo, 1996. 220p. Tese (Doutorado) - Faculdade de Economia, Administração e Contabilidade, Universidade de São Paulo.

GOMES, G.M. Caráter e conseqüências da intervenção estatal no setor açucareiro do Brasil: 1933/1978. Estudos Econômicos, v.9, n.3, p.123-150, set./dez. 1979. 
HELFAND, S.M. The political economy of agricultural policy in Brasil: interest groups and the pattern of protection. Berkeley, 1994. 273 p. Thesis (Doctor of Philosophy PHD) - University of California.

HUBBARD, M. The "New Institutional Economics" in agricultural development: insights and challenges. Journal of Agricultural Economics, v.48, n.2, p.239-249, 1997.

INDIA edges towards liberalization of its sugar industry. F.O. Licht's International Sugar and Sweetener report, v.129, p.281-286, April 1997.

$\mathrm{KOCH}, J . \mathrm{V}$. Industrial organization and prices. 2.ed. New Jersey: Prentice-Haal, 1980. $504 \mathrm{p}$.

KUEZLER, L.T. Privatization of the sugar market in México. In: Agriculture in liberalizing economies: changing roles for governments. AGRICULTURAL SECTOR SYMPOSIUM, 14., Washington, 1995. Proceedings. Washington: World Bank, 1995. p.293-305.

LAMOUNIER, B. Determinantes políticos da política agrícola: um estudo de atores, demandas e mecanismos de decisão. Estudos de Política Agrícola, n.9, p.1-26, jan. 1994.

BRASIL. Ministério da Indústria e Comércio. Instituto do Açúcar e do Álcool. Leis, decretos-leis e decretos, v.1. Legislação açucareira e alcooleira.

MACEDO, I.C. Greenhouse gas emissions and bio-ethanol production / utilization in Brazil. Piracicaba: CTC, 05/97, jan. 1997. 14p.

MACHADO, J. Proálcool: momentos decisivos. Preços Agrícolas, n.141, p.8, jul.1998.

MASTEN, S. Empirical research in transaction-cost economics: challenges, progress, directions, 1994, 26p. (mimeo).

NASTARI, P.M. Tendências mundiais para o mercado de açúcar e de álcool. In: TENDENCIAS DE PREÇOS E QUESTÕES POLÍTICAS DETERMINANTES PARA O MERCADO DE AÇÚCAR E ÁlCOOL, São Paulo, 1999. Anais. São Paulo: International Business Communication, 1999. 
NEVES, M.F.; LAZZARINI, S.G.; CHADDAD, F.R. Contrabalançando a concentração no agribusiness: ações coletivas de produtores agrícolas Preços Agrícolas, v.14, n.152, p.52-53, jun. 1999.

NOLL, R.G. Economic perspectives on the politics of regulation. In: Schmalensee, R.; Willig,R.D. (ed.) Handbook of industrial organization. Amsterdam: Elsevier Sciense Publisher, 1989, cap.22, v.2, p.1254-1287.

NORTH, D.C. Institutions, institutional change and economic performance. New York: Cambridge University Press, 1990. 152p.

NORTH, D. Institutions. Journal of Economics Perspectives, n.5, p.97-112, Winter, 1991.

PETIT, M. Agriculture in liberalizing economies. In: Agriculture in liberalizing economies: changing roles for governments. AGRICULTURAL SECTOR SYMPOSIUM, 14., Washington, 1995. Proceedings. Washington: World Bank, 1995. p.445-455.

PINA, H. A agroindústria açucareira e sua legislação. Rio de Janeiro: APEC, 1972. $364 \mathrm{p}$.

PINDYCK, R.S.; RUBINFELD, D.L. Microeconomia. São Paulo: McGraw Hill, 1994. $968 \mathrm{p}$.

QUEDA, O. A intervenção do Estado e a agroindústria açucareira paulista. Piracicaba, 1972. 173p. Tese (Doutorado) - Escola Superior de Agricultura "Luiz de Queiroz", Universidade de São Paulo.

QUEIROZ NETO, J.R.C. Economia do setor canavieiro do nordeste. In: TENDÊNCIAS DE PREÇOS E QUESTÕES POLÍTICAS DETERMINANTES PARA O MERCADO DE AÇÚCAR E ÁlCOOL, São Paulo, 1999. Anais. São Paulo: International Business Communications, 1999.

RABOBANK Sugar and Sweeteners. Netherland, 1995, 106p.

RAMOS, P. Agroindústria canavieira e propriedades fundiárias no Brasil. São Paulo, 1991, 2v. Tese (Doutorado) - Escola de Administração de Empresas de São Paulo, Fundação Getúlio Vargas. 
RIBEIRO, S.K. O álcool e o aquecimento global. Rio de Janeiro: CNI/COINFRA/COPERSUCAR, 1997.112p.

SAES, M.S.M. Associações de interesse privado, coordenação e competitividade: um caso no sistema cafeeiro. In: SEMINÁRIO BRASILEIRO SOBRE A NOVA ECONOMIA INSTITUCIONAL, 1. São Paulo, 1998. Anais. São Paulo: Universidade de São Paulo, 1998. 12p.

SANTOS, M.H.C. Política e políticas de uma energia alternativa: o caso do proálcool. Rio de Janeiro: Notrya, 1993. 352 p.

SERODIO, E. Analisando as políticas existentes e traçando perspectivas para o setor sucroalcooleiro. In: TENDÊNCIAS DE PREÇOS E QUESTÕES POLÍTICAS DETERMINANTES PARA O MERCADO DE AÇÚCAR E ÁLCOOL, São Paulo, 1999. Anais. São Paulo: International Business Communications, 1999.

SERODIO, E. et al. Propostas de políticas públicas para o setor sucroalcooleiro: do monopólio ao livre mercado. Brasília: Ministério da Indústria, do Comércio e do Turismo, 1998. 27p.

SHERER, F.M. Industrial market structure and economic performance. Boston: Houghton, $1980.632 \mathrm{p}$.

SILVA, G.M.A. Liberação de preços no setor canavieiro: modelo de auto-gestão do setor no estado de São Paulo. In: SEMANA DA CANA-DE-AÇÚCAR DE PIRACICABA, 3, Piracicaba, 1998. Anais. Piracicaba: STAB, 1998. p.8-9.

SILVA, G.M.A. Cana crua x cana queimada. In: SEMANA DA CANA-DE-AÇÚCAR DE PIRACICABA, 2, Piracicaba, 1997. Anais. Piracicaba: STAB, 1997. p.55-57.

SOUZA, J.S.G.; SOUZA, S.A.M. Alternativas econômicas para áreas com restrições à colheita mecanizada da cana-de-açúcar, na região de Piracicaba - SP. In: SEMANA DA CANA-DE-AÇÚCAR DE PIRACICABA, 3, Piracicaba, 1998. Anais. Piracicaba: STAB, 1998. p.4-8.

SZMRECSÁNYI, T. O planejamento da agroindústria canavieira do Brasil (19301975). São Paulo: HUCITEC / Universidade Estadual de Campinas, 1979. 540p. 
THE NEW Proalcool. F.O. Licht's International Sugar and Sweetener Report. v.129, n.4, 24 jan. 1997.

WILLIAMSON, O. The economic institutions of capitalism. New York: The Free Press, 1985. 450p.

WILLIAMSON, O. The mechanisms of governance. New York: Oxford University Press, 1996. 429p.

ZYLBERSZTAJN, D. Estruturas de governança e coordenação do agribusiness: uma aplicação da Nova Economia das Instituições. São Paulo, 1995. 238p. Tese (Livre Docência) - Faculdade de Economia, Administração e Contabilidade, Universidade de São Paulo. 


\section{Apêndice 1 - Questionários}

\subsection{Questionário industriais}

1. Qual o nível de regulamentação estatal que o Sr. acha que o setor deve ter? O Estado deve se afastar parcialmente ou totalmente? Por quê?

2. Quais as causas o Sr. acredita foram responsáveis por tantos adiamentos do processo de desregulamentação do setor?

3. Em relação às diferenças regionais, o que o Sr. pensa sobre os subsídios dados aos produtores de cana dos Estados de MT, MS, GO, MG, RJ, ES, PA, e TO, além dos já existentes para o NE?

4. Qual sua opinião sobre os problemas de logística enfrentados pelas unidades oriundas do Proálcool? Elas têm condição de sobreviver sem o subsídio referente ao frete de transporte?

5. Dentro do setor existem duas correntes, cujos objetivos de longo prazo são diferentes, já que uma defende a volta do carro a álcool e a outra o estímulo ao anidro. O que o Sr. pensa sobre a questão Anidro x Hidratado?

6. A comercialização do açúcar já é feita sem a interferência do governo. Funciona bem?

7. O álcool não compete, em termos estritamente econômicos, com a gasolina. $O$ sistema de viabilização do álcool atualmente existente - via conta PPE, da Petrobrás - vai até agosto de 2000. Qual o mecanismo o Sr. acredita virá substituí-lo?

O Sr. acha que a sociedade está pronta para aceitar o imposto seletivo?

8. O subsídio de $\mathrm{R} \$ 0,045$ por litro de álcool é suficiente para adequar a produção à demanda? Deve haver um planejamento de produção? Ele deve ser feito pelo governo ou pela iniciativa privada?

9. A diferença entre o número de produtores de álcool e o número de distribuidoras de combustíveis, bem como o modo de agir de algumas pequenas têm sido citados como uma forma das distribuidoras grandes pressionarem para baixo os preços do álcool.

É necessária alguma forma de ação governamental nesta negociação? 
10. O Sr acha que o modelo CONSECANA deve ser efetivado e usado em todo o Pás? Ele funciona sem arbitragem governamental?

11. O que o Sr. pensa sobre:

- Tabelamento de preços pelo Estado?

- Estabelecer preços mínimos?

- Estabelecer quotas de produção?

- Planos de Safra?

- Criar agência reguladora específica para o setor ou continuar a própria ANP ?

12. Quais as novas formas requeridas da ação estatal em nível Federal?

13. Quais as novas formas requeridas da ação estatal em nível Estadual?

14. A ação estatal até agora foi eficiente? O CIMA funciona?

15. O industrial tem informação suficiente sobre o mercado (de açúcar, do álcool e da cana)?

16. Existe assimetria de informação entre os agentes da cadeia que requeiram a intervenção do governo?

17. Sua entidade tem proposta formal sobre a desregulamentação? 


\section{A pêndice 1 - Questionários - continuação}

4.2 Questionário fornecedores de cana

1. Qual o nível de regulamentação estatal que o Sr. acha que o setor deve ter? O Estado deve se afastar parcialmente ou totalmente? Por quê?

2. Quais as dificuldades o Sr. enxerga no processo de desregulamentação?

3. Quais as novas formas requeridas da ação estatal em nível Federal?

- Efetivação modelo Consecana?

- Tabelamento de preços pelo Estado?

- Estabelecer preços mínimos?

- Estabelecer quotas de produção?

- Planos de Safra?

- Criar agências reguladoras?

4. Quais as novas formas requeridas da ação estatal em nível Estadual?

5. A ação estatal até agora foi eficiente? O CIMA funciona?

6. Quais as entidades que assumirão as funções previamente exercidas pelo Estado? Quem vai coordenar o novo sistema?

7. A comercializaçäo do açúcar já é feita sem interferência do governo. Funciona bem? Qual a diferença em relação ao álcool?

8. Quais as características $\operatorname{do}(\mathrm{s}) \operatorname{seu}(\mathrm{s})$ produto(s) e da sua produção que dificultam vendê-lo no mercado desregulamentado?

9. A diferença entre o número de fornecedores e o número de usinas/destilarias dificulta a negociação?

10. O fornecedor tem informação suficiente sobre o mercado (de açúcar, do álcool e da cana)? Existe assimetria de informação entre os agentes da cadeia?

11. Sua entidade tem proposta formal sobre a desregulamentação? Poderia ser fornecida uma cópia? 


\section{Apêndice 1 - Questionários - continuação}

\subsection{Questionário governo}

1. Qual o nível de regulamentação estatal que o $\mathrm{Sr}$. acha que o setor deve ter? O Estado deve se afastar parcialmente ou totalmente? Por quê?

2. Em relação às diferenças regionais, o $\mathrm{Sr}$. acha que os subsídios dados recentemente aos produtores de cana dos Estados de MT, MS, GO, MG, RJ, ES, PA, e TO, além dos já existentes para o NE, são necessários para a sobrevivência destas regiões ou eles devem ter duração limitada?

3. Qual sua opinião sobre os problemas de logística enfrentados pelas unidades oriundas do Proálcool? O governo tem ainda algum compromisso com estas unidades ou somente com o abastecimento de álcool?

4. Elas receberão o subsídio referente ao frete do transporte somente por um tempo limitado? Elas têm condição de sobreviver sem o subsídio?

5. Dentro do setor existem duas correntes, cujos objetivos de longo prazo são diferentes, já que uma defende a volta do carro a álcool e a outra o estímulo ao anidro. O que o $\mathrm{S}_{\mathbf{r}}$. pensa sobre a questão anidro $x$ hidratado?

6. Embora o preço da tonelada da cana-de-açúcar ainda estivesse tabelado até $1^{\circ}$. de fevereiro de 1999, muitas regiões do Centro-Sul já praticaram o modelo CONSECANA na safra 98/99. Diversas associações de fornecedores reclamaram de seu funcionamento na referida safra.

7. Sr. acha que ele funcionará sem a interferência do Governo ou requer uma arbitragem governamental?

8. O álcool não compete, em termos estritamente econômicos, com a gasolina. $\mathrm{O}$ sistema de viabilização do álcool atualmente existente - via conta PPE, da Petrobrás - vai até agosto de 2000. Qual o mecanismo o Sr. acredita virá substituí-1o?

9. Sr. acha que a sociedade está pronta para aceitar o imposto seletivo?

10. O planejamento do setor deve partir do governo ou do setor privado?

11. Este novo modelo de subsídio (dado somente sobre a demanda efetiva de cada Estado) tem duração limitada? 
12. subsídio de $\mathrm{R} \$ 0,045$ por litro de álcool é suficiente para adequar a produção à demanda?

13. O que o Sr, pensa sobre a Brasil Álcool?

14. A diferença entre o número de produtores de álcool e o número de distribuidoras de combustíveis, bem como a conduta de algumas (sonegação de impostos, custos mais baixos, adulteração de combustíveis) têm sido citados como uma das dificuldades da comercialização dos preços do álcool. É necessária alguma forma de ação governamental nesta negociação?

15. É necesssária a criação de uma nova agência reguladora ou a própria ANP se encarrega de intervir em eventuais conflitos?

16. O que o Sr. pensa sobre:

- Tabelamento de preços ou estabelecimento de preços mínimos pelo Estado?

- Estabelecimento de quotas de produção?

- Planos de Safra?

- Assistência social aos plantadores de cana? 


\section{Apêndice 1 - Questionários - continuação}

1.4 - Questionário de parlamentares

1. O que o seu Partido pensa sobre o setor sucroalcooleiro?

2. A força política da bancada nordestina tem sido citada como uma das responsáveis por diversas ações do Governo Federal que acabam privilegiando aqueles estados.

Por sua vez, a força política de São Paulo tem sido considerada pequena proporcionalmente ao seu tamanho. O que o Sr. pensa disto?

3. Qual o nível de regulamentação estatal que o Sr. acha que o setor deve ter? O Estado deve se afastar parcialmente ou totalmente? Por quê?

4. Qual o novo papel do Governo Federal em relação ao setor?

5. E do Governo Estadual?

6. Como fica a questão do emprego e a legislação estadual que proíbe a queima da cana? O Sr. acha que haverá uma flexibilização em relação ao problema da queimada?

7. O que o Sr. pensa sobre o problema da assistência social aos plantadores de cana?

8. O que o Sr. pensa sobre a questão anidro $x$ hidratado, ou seja, deve haver uma retomada ao carro a álcool, estímulos ao uso do álcool como aditivo ou ambos?

9. O planejamento do setor deve partir do governo ou do setor privado?

10. O álcool não compete em termos estritamente econômicos com a gasolina. $\mathrm{O} \mathrm{Sr}$. acha que o imposto seletivo pode ser uma boa maneira de viabilizar o álcool hidratado?

11. O Sr. acha que o relacionamento fornecedor de cana indústria precisa de uma arbitragem governamental?

12. A diferença entre o número de produtores de álcool e o número de distribuidoras de combustíveis tem sido citados como uma das dificuldades da comercialização dos preços do álcool. É necessária alguma forma de ação governamental nesta negociação? 


\section{Apêndice 1 - Questionários - continuação}

\subsection{Questionário comercialização álcool (membro câmara técnica CIMA)}

1. Como funcionava a mesa de comercialização?

- Como eram distribuídas as cotas, baseadas na produção?

- Existiam muitos problemas de informação de produção?

- Qual era a lei?

- Era para anidro e hidratado?

2. Como era este sistema da sustentação econômica, de isenção parcial de ICMS? Havia problemas?

3. Neste novo modelo, o subsídio é somente sobre certa quantia, baseada na demanda. Questões:

- É só sobre o hidratado?

- Como vai ser a comercialização com a distribuidora, existe controle sobre o que tem ou não subsídio?

- Como era o passeio do álcool? Está resolvido, agora que o subsídio vai direto para o produtor?

4. Qual sua opinião da questão anidro $x$ hidratado?

5. O preço da gasolina ainda é controlado nas refinarias. Quais os problemas quando for liberado?

6. Em relação aos contratos com as distribuidoras:

- você acha que deve haver uma regulamentação mínima?

- Eles são contratos ou acordos de entrega (cláusula de reajuste de preço periódico)

7. Você acha que deve ter uma regulamentação que obrigue as distribuidoras contratarem certo volume para evitar que seja comprado tudo no spot?

8. Como elas compram, qual a logística?

9. Você acha que o Imposto Seletivo é a melhor forma para viabilizar o álcool? Precisa de interferência do govemo?

10. Você pode falar um pouco sobre a Brasil Álcool?

11. Você acha que o governo deveria fazer estoques reguladores? 
12. Você tem dados sobre a evolução do market-share delas? Gostaria de calcular as razöes de concentração para verificar eventual poder de mercado.

13. Distribuidoras grandes $x$ pequenas. Quem é a vilã? 